
Digitized by the Internet Archive in 2007 with funding from Microsoft Corporation 


\section{ECONOMIC FOUNDATIONS}

\section{OF SOCIETY}

FY

\section{ACHILLE LORIA}

TRANSI,ATED gROM THE SECOND FRLNCH EDITION

BY

\section{IINDLEY M. KEASBEY}

ASSOCIATE PROFESSOR OF POLITICAL SCIENCES, BRYNMAWR COLIEGE, PENNSYLVANIA

WITI A NEW PREFACE BY THE AUTHOR

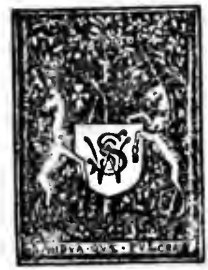

LONDON

SIVAN SONNENSCIEIN AND CO., IIM.

NEW YORK: CHARIES SCRIBNER'S SONS 


\section{SOME OPINIONS OF THE PRESS.}

"Professor Loria ranks as the most learned of Italian Economists, and his book certainly does contain a marvellous amount of what Comte called Erudition, that is to say, of historical knowledge."-Speaker.

"Whether his conclusions be accepted or rejected, no one can follow his argument without feeling that fresh light is thrown upon the idols of the market place, and that many of the dogmas of conventional political economy are in sad need of revision."-Annals of American Academy.

"Signor Loria's book is a suggestive and obviously sincere work, and in associating himself with the cause of the weak against the strong, he has a laudable end in view."-Westminster Gazette.

"Students of economics will find this a most valuable work."-Literary Guide.

"In M. Loria's work there is much that will interest the student of the subjects, for he deals exhaustively with all the various economic phases, and has produced a book which has the merit of being written in a simple style." -British Fournal of Commerce.

"A remarkable book in its way."-Scotsman.

"The work is ably, even eloquently, written, and is admirably transiated." -Glasgow Herald.

FIRST EdITION, February, IgO2; REPRINTEd, April, roo4; January, 1907. 


\section{TO MY DEARLY \\ BELOVED SISTER}




\section{TRANSLATOR'S PREFACE.}

MODERn sociologists are still groping about for a point of departure from which to explain the complex of social phenomena. It was easier for the philosophers of the last century, for all were then agreed that Society was to be "rightly constituted by victorious Analysis". But Philosophism has had its day, and Positivism now reigns in the domain of social science. We no longer hope to reconstitute society upon a fabulous state of nature; we are seeking now to discover the natural laws of social evolution.

On the one side there are the biological sociologists who would determine the principles of the new science by analogies drawn from the animal world. But it is not enough merely to substitute super-organic for organic evolution, and proceed at once to confer biological definitions upon sociological facts. True, the terminology of the science is thereby enriched and its methods somewhat improved; but the principles peculiar to social growth still remain to be discovered. There is also a group of psychological sociologists who seek the motives of collective life in the individual instincts of the man. But personal proclivities are so largely the result of historical inheritance and the social environment, that there is constant danger in pursuing this method of confusing cause with consequence, and thus becoming involved in a vicious circle. It is difficult, besides, without some guiding principle, to hit upon instincts that are especially 'characteristic of the human species, and at the same time sufficiently original and universal to apply to all social phenomena. Still another coterie of geographical sociologists endeavours to explain society from the 
standpoint of the physical environment. Racial peculiarities may perhaps be accounted for on these grounds, and there can be no doubt that early social development is strictly determined by geographic factors, or that variations in primitive communities are largely the result of differences in environmental conditions; but modern society is far removed in time and acquired attainments from purely physical nature, and it is impossible any longer to refer historical phenomena directly to their geographical antecedents.

A modicum of the truth is, indeed, contained in each of the above-mentioned explanations of social phenomena; no one alone is able, however, to account for the "standing miracle of this world". A term is still lacking to explain the peculiar constitution of society and mark off the collective activities of mankind from similar phenomena occurring in the animal world. What is required is some unifying concept that will take from biology, psychology and geography the necessary first principles, and construct these premisses into a distinctly sociological theory. How then shall we describe the immediate antecedents of society?

Aristotle categorically declared that "man is by nature a political animal," and Darwin also took it as an axiom that "man is a social being". But this is not strictly true. The human being may inherit certain traits that make for collective activity, but to say that he is naturally political or social is purely gratuitous. The ape-like progenitors of man evidently lived, like their nearest simian relatives to-day, in detached family groups, and the lowest savages to-day know nothing of political or social organisation. It is evident thus that the social faculties of man are a later acquisition, and, if we mistake not, they were originally derived from the antecedent economic instinct. It is impossible, of course, to separate man sharply from the animal world; but qualitatively, at least, he is to be distinguished from the lower orders by his marked economic capacity. As far back as we know anything about him, the human being has shown a conscious desire to improve his lot. 
He wishes to satisfy his increasing wants, and so acquire pleasure; he is equally anxious to rise superior to the antagonistic forces surrounding him, and so avoid pain. So long as he could gain his quotum of pleasure and avoid unnecessary pain without the help of his fellows, isolated production was the rule, and the family constituted the largest social group. But as the economic struggle for existence became more severe, utilitarian motives led to co-operation and association, and the family was accordingly enlarged into the clan and the tribe. Economic necessity thus determined the original forms of social life, and collective activity was primarily derived from that natural desire common to all sentient beings, but peculiarly characteristic of man, to avoid the evil things and obtain the good things of the material world.

On its subjective side sociology is thus connected with biology by economic psychology. But as superorganic evolution is equally as dependent as organic evolution upon the physical world, it is left for environmental conditions to give direction to the economic instinct of man, and so determine the peculiar constitution of society. Thus, on its.objective side, sociology is connected with biology by economic geography. In short, the antecedents of society are strictly economic in character, and, in its broadest sense, economics constitutes the logical link connecting sociology with the preceding sciences.

Now the heretofore independent science of political economy is itself established upon psycho-geographical premisses, and stands ready at hand to apply the logic of its limited conclusions to the broader sociological field. Thus, if it is possible to account for the origin of society on economic grounds, it is certainly consistent to continue the same method and refer the abstract principles of political economy to the concrete development of social institutions. The economic would seem thus to be the only proper point of departure for the study of social phenomena, and it may well be that by applying the economic laws of production and consumption, distribution and exchange, historically to social evolution the sociological 
process will itself become intelligible and the true philosophy of history stand revealed.

Such at least is M. Loria's conviction, and in describing the economic foundations of society he has certainly rendered inestimable service to the coming science of society. Like Aristotle, our author divides social evolution into two distinct stages, the precapitalistic and the capitalistic. M. Loria's "final economy" established upon free land is Aristotle's "natural economy," where there was no "retail trade" ; each is non-capitalistic in character, and both form the first and last terms of social evolution. Unlike Aristotle and all subsequent writers, M. Loria, however, continues to rate the intermediate stages of historical development in economic terms. This long period of elaboration he divides again into three epochs, the slave-economy, the serf-economy, and the wage-economy, and proceeds to show how the "connective institutions of society," morality, law and politics have been consistently dominated through these three stages by a capitalistic spirit.

Objections have been raised to M. Loria's general point of view, as well as to his particular conclusions, but as the atthor meets these criticisms himself in this edition of his work it would be out of place to anticipate the discussion in the preface. Being in such hearty accord with the economic theory of our author, we do not wish to take captious exception to any part of his doctrine. It does scem to us, however, that rather too exclusive importance is attached to the land as a sociological factor, and too little weight given to other forms of capitalistic opportunity. Nor do we find that the geographic premisses of the argument receive the attention they should to make the dynamics of the economic theory effective. On the other hand, M. Loria's greatest contributions to economic sociology appear to us to lie in the domain of political scicnce. His theory of the economic basis of political sovereignty is especially remarkable, and his description of the political function of the "unproductive labourers" may almost be regarded in the light of a revelation. 
But what we desire above all, in introducing the work of this illustrious Italian scholar to the great English-speaking public, is to emphasise the significance of his general point of view, and insist upon the correctness of his economic analysis of society. Indeed, there is a special fitness in presenting these theories in the classic land of Political Economy, and before a people whose activities have been so largely along economic lines. It is our hope, therefore, that in its present English form M. Loria's work will continue to receive the marked attention thus far accorded it on the Continent.

Translation involves an inevitable loss both in style and lucidity, and we cannot but feel that the present book has suffered exceptionally from the process. We trust, therefore, that all shortcomings in this direction will be laid at the door of the translator, for in the original Les Bases Economiques de la Constitution Sociale is a model of good logic and elegant diction.

L. M. KEASBEY, 


\section{AUTHOR'S PREFACE.}

The rich ruleth over the poor and the borrower is servant to the lender.

Proverbs, xxii. 7.

Una genie impera e l'altra langue.

Dante, Infermo, viii. 82.

ThirteEN years ago I sketched a rough outline of the present work to serve the modest purpose of an inaugural dissertation for the University of Sienna. I had little thought at that time that the book would ever have the honour of being translated. Nor can 1 attribute the flattering reception my original work received entirely to its intrinsic worth, for the merits of the first edition were slight. I must rather refer the success of the book to the perfect frankness with which it denounced the enormities of contemporary morals and politics, and set the plain truth over against the systematic falsification of things so common to modern sociologists. The book revealed the secret to the world: it boldly declared what no one had had the courage to say, that cupidity, narrow, mean egoism and class spirit ruled in our so-called democracies; it ruthlessly unmasked the political deities that the world had been in the habit of invoking with pompous phrases, and, raising the veil that covered them, it showed that where we had expected to find the mystical I sis, there was only a yawning greedy crocodile. To some the revelation seemed bold, to others sacrilegious, but to all extremely interesting. Thus the fragile bark, intended only for the tranquil waters of Tuscan rivers, has made a tour of the world and navigated distant seas without suffering serious shipwreck.

Nnw that opportunity has offered itself to put forth the results of my continued researches before a larger public, instead of publishing a bare translation of the original Italian 
edition, I have decided to undertake a complete revision of the work. The flattering reception my book received has imposed new obligations upon the author, however, and it has become incumbent upon me to submit my conclusions to a searching examination, and support them with fresh analysis - and repeated proof. This task, I may say without hesitancy, I have conscientiously fulfilled. All parts of my main thesis have been scrupulously examined and revised, and the theory itself has been amplified and completed. It is thus less of a translation of the original work than an entirely new book $I$ offer in this edition. On account of the new matter introduced, and the important modification of the old, the present work is far superior, in my own opinion, to the original edition.

That the book still contains imperfections I shall be the first to admit. In spite of the many improvements made in the text, I feel I ought to repeat, by way of preface to this translation, what I remarked concerning the first edition: "It is after all but a sketch, a rapid review of the principal aspects of a theme which demands closer investigation and considerable enlargement ". Nevertheless, imperfect as it is, l cannot but believe that the work will prove of some value, and that it will induce more competent scholars to accord these studies the technical skill and broad knowledge of philosophy, law and politics that an intellect, strolling through a field not peculiarly his own, cannot well be expected to possess. And it may be permitted me to hope that in its more ambitious form my book will enlist as much, if not more, sympathetic attention than the original edition received. Let us trust that the larger vessel will have no less happy a voyage than the little bark on whose lines it has been constructed! Such is my ardent hope in launching these pages upon the stormy sea of international science.

$O$ navis, referent in mare te novi

Fluctus !...

ACHILLE LORIA.

Padua, September, 1898. 


\section{TABLE OF CONTENTS.}

PAGE

Translator's Preface • • . • • . . . . . vi Author's Preface . . . . . . . . . . . xi Introduction.--The Economic Constitution of Society . . . 1

\section{PART I.}

The Economic Foundations of Morality.

Chapter I.-The Morality of the Final Society . . . . 13 Chapter II.-Morality in the Capitalistic Society . . . 17 Cijapter III.-A Comparison of the Different Systems of Morality 43 Chapter IV.-Moral Crises . . . . . . . . . 5I Cinapter V.-A Critique of the Dominant Theories of Morality $\quad 59$

\section{PART II.}

The Economic Foundations of the law.

Chapter I.-The Economic Basis of Legal Sanctions . 73 ChAPTER II.-The Economic Basis of Legal Transformations-An Historical Demonstration . . . . . 80

Chapter III.-The Economic Basis of Divers Legal Institutions . 87 I.-The Law of the Family . . . . $\quad$ - 87 II.-The Law of Property . . . . $\quad$. 90 III.-The Law of Inheritance . . . . . 93 IV.-The Law of Contract . . . . . 100

V.-The Law Regulating the Relations between Masters and Workmen . . . . . 103 V1.-Criminal Law . . . . . . 107 


\section{PART III.}

The Economic Foundations of Politics.

Chapter I.-Economic Revenue and Political Sovereignty • 117

Chapter II,-The Bipartition of Revenue and Sovereignty . 153

Chapter III.-Manifestations of Revenue and Sovereignty . . 206

I.-Financial Policy . . . . . . 206

II.-Domestic Politics . . . . . . 249

III.-Foreign Politics . . . . . . 256

Chapter IV.-Revolutions of Revenue and Sovereignty . . 289

Chapter V.-Property and Politics . . . • . 327

Chapter VI.--In Answer to Some Objections . . . . . 355

Conclusion.-Economics the Basis of Sociology . . . $\quad$ - 380 


\section{INTRODUCTION.}

\section{THE ECONOMIC CONSTITUTION OF SOCIETY.}

IF we examine attentively the societies developing at the present day in the civilised countries of the old and new worlds, they present, we find, one common phenomenon: absolutely and irrevocably all of them fall into two distinct and separate classes; one class accumulates in utter idleness enormous and ever-increasing revenues, the other, far more numerous, labours life-long for miscrable wages; one class lives without working, the other works without living-without living a life, at least, worthy of the name. When confronted by so marked and so painful a contrast, the question must at once occur to every mind that reflects: Is this sad state of affairs the result of inherent necessity, inseparable from the organic conditions of human nature; or is it merely the outcome of certain historical tendencies that are destined to disappear at a later stage of social evolution?

After a long mental pilgrimage through the vast domain of economic sociology, I, for my part, have arrived at the conclusion that the truth is to be found in the latter alternative: that capitalistic property, with its caste division of humanity into capitalists and labourers, is by no means the product of conditions inherent in human nature, but simply the result of powerful historical causes which will eventually disappear. In support of this conclusion, I shall have occasion, in the course of the present work, to set forth a variety of facts. But before entering into the complexities of the problem, 1 will undertake at the outset to outline the results of my investigations in the following rough slicteh. 
In this way I would account for the genesis, the character and the tendencies of capitalistic property: while free lands exist that can be cultivated by labour alone, and when a man without capital may, if he choose, establish himself upon an unoccupied area, capitalistic property is out of the question; as no labourer is disposed to work for a capitalist when he can labour on his own account upon land that costs him nothing. Evidently, therefore, while such conditions prevail, the labourers will simply take possession of the free lands and apply their labour to the soil, adding to this the capital they accumulate.

In case the productivity of the land be high, these producers of capital, as 1 shall call them, will not be disposed to co-operate, as it is not at all to their advantage to subject their natural independence to the restraints of association, merely to increase a product which is already sufficiently abundant in itself. Under this supposition, isolated production constitutes, therefore, the natural economic form; unless, perchance, the despotic authority of the State compels the producers to co-opcrate. If, however, the productivity of the land be low, a motive will at once appear, urging the producers to join their forces with a view to increasing the product. The necessary economic form under this hypothesis, is consequently, either a partnership of producers of capital, who labour jointly and divide the product in equal parts-and this I shall call the simple association -or a voluntary co-operative group composed of one or more producers of capital and one or more ordinary labourers, who act conjointly, each receiving an equal share in the product-and this we shall speak of as the mixed association. But free land being given, the above-mentioned division of society into a class of non-labouring capitalists, and a class of non-capitalistic labourers, is in either case out of the question; for under such circumstances, it is impossible for an idle capitalist to acquire any profit.

Access to the free lands, whence the labourers derive their power and their independence, must, consequently, be in some way cut off before capital can acquire any profits. And if, on 
account of the sparsity of population, the soil itself cannot be entirely appropriated, access to the free lands can only be prevented by subjugating the labourers themselves. Property in human beings is, therefore, the first step toward the realisation of capitalistic ownership. At the outset the subjugation of the labouring population may be accomplished under the brutal form of slavery; but, later on, when the declining productivity of the soil has to be offset by labour of a higher degree of efficiency, slavery must be mitigated in the interests of production by some milder form of servitude.

Colonial countries, where free lands abound, offer striking illustrations of these propositions, and any one who has rightly comprehended the development of these interesting lands, must recognise the truth of our assertions. Note, for example, in the descriptions of the early days of the United States, how this fortunate country is depicted as inhabited by a noble race of independent labourers, ignorant of the bare possibility of capitalistic property ; read IVashington's letters which tell how impossible the farmers found it to acquire any income whatsoever from their lands unless they cultivated them along with their labourers; and mark how Parkinson, Strickland and other Europeans who travelled in America during the eighteenth century, were one and all struck with amazement at this strange land where money did not breed money. We can also understand why the slave system of the ancient world and the serfdom of the middle ages were both re-introduced into our modern colonies; for it was only by resorting to such means that profits could be acquired during these epochs preceding the appropriation of the soil.

Certain economic phenomena of the middle ages also illustrate the effects produced by the existence of free land. Thus with the disappearance of serflom from manufacturing industries while fertile lands still remained unoceupied, there developed that primitive form of the mixed association known as the crafts-gild, which categorically excluded profit by dividing the 
product in equal proportions between the producers of capital (the gild-masters) and the ordinary labourers (the journeymen). And as profits could only be extorted by violence, persecution of the workmen followed in time as a natural result. The prohibition of usury was another outcome of these conditions; for the capitalists' difficulty in acquiring profits from industrial enterprise rendered the very idea of interest on capital inconceivable, and thus naturally caused it to be regarded as the result of theft or fraud.

But the normal increase of population eventually results in the appropriation of all lands cultivable by labour alone, and the economic system then undergoes a radical transformation. The labourer now loses that liberty of choice which up to this constituted his safeguard against the usurpations of capital, and henceforth he has no means of livelihood other than to sell his labour to the capitalist for the wages which it pleases the latter to determine. The wage-earner is now actually compelled to give over to the capitalist the better part of the product, and so accord the latter a profit on his capital. In this way profits are instituted automatically, no longer through violence, but simply by dint of the progressive appropriation of the soil. This process, by depriving the labourer of his liberty of choice, establishes his economic bondage.

The simple appropriation of all lands cultivable by labour alone does not, however, succeed in completely guaranteeing the existence of the capitalistic economy, for there must still remain a great number of plots whose cultivation, it is true, cannot be undertaken without some capital, but which do not require any great amount. Were the labourers thus in a position to lay by sufficient wealth, with the possibility still open of establishing themselves upon free land, they would at once recover their liberty of choice, and the exclusion of all profits would be the inevitable result. Thus the reduction of wages to a minimum, preventing the possibility of accumulation, is the condition sine qua non of the continuance of the capitalistic economy; and it is, consequently, indispensable for the 
capitalists to reduce the remuneration of their labourers to the strictest necessities.

This reduction of wages to a minimum may be brought about in a variety of ways: by the actual lowering of wages; or through the depreciation of money; or by means of the introduction of machinery more costly than the labour which it replaces; or by the expansion of unproductive capital employed in credit and banking transactions, in the use of metallic money, and in public debts; or through the introduction of an excessive number of useless intermediaries; or by the creation of a superfluous population producing competition among the workmen employed. It is true, all these methods put a check on production and correspondingly diminish the surplus, but, nevertheless, the proprictary class cannot refuse to employ them, as they afford the only means of assuring the persistence of profits, by preventing a rise in wages which would inevitably result in the total suspension of the revenue derived from capital.

But a further augmentation of population must eventually result in the total occupation of the land, and the capitalists' exclusive appropriation of the soil then suffices of itself to deprive the labourers of their liberty of option and afford a perpetual income to property. Capitalists thus find themselves relieved of the necessity of having to resort to costly and unproductive means of reducing wages in order to guarantee the continuance of their incomes. The action of capitalistic property becomes henceforth automatic-that is to say, it continues to exist without any clirect effort on the part of the capitalist toward restricting the liberty or liniting the remuneration of the labourer. The capitalists, in other words, have only to sce to it, henceforth that landed property does not escape from their grasp in order to be assured of a perpetual income at the expense of the labouring class. Thus the basis of capitalistic property is always the same, it rests upon the suppression of the free land and the exclusion of the labourer lrom access to the productive powers of the soil. 
This exclusion is accomplished by different means following the different stages in the progressive occupation of the land, and according to the varying degrees of fertility of the soil. So long as there remain free lands which can be cultivated by labour alone, suppression can only be accomplished by means of slavery and serfdom; but when the still unoccupied stretches can only be cultivated by those who possess capital, suppression of the free lands can then be effected by means of a systematic reduction of wages on a scale which does not allow the labourers to accumulate wealth. Finally, when the augmentation of population malkes it possible to occupy all the land then, at last, suppression can be accomplished by the simple appropriation of the soil on the part of the capitalist class. The transition from one to another of these successive phases in the suppression of the free land is effected through an economic revolution, which decomposes the effete social system, and brings to light a new social form.

Besides thus radically affecting distribution, the suppression of the free land also exercises two opposing influences upon production. By co-ordinating the efforts of slaves, serfs and wage-earners, the suppression of the free land does, indeed, have the effect of rendering labour more efficient. But, on the other hand, the compulsory character of such co-operation necessarily confines production within sensible bounds, which can only be stretched to a limited degree by the introduction of less restrictive methods of suppressing the free land. Cooperative labour is, in other words, more productive than individual labour, but compulsory co-operation is still inferior in efficiency to voluntary co-operation. If, then, free access to lands of a high degree of fertility would naturally engender an economy of isolated producers, suppression of the free land is in this case technically superior to free land itself, and constitutes a step toward progress and civilisation. But in cases where the poor quality of the soil would of itself naturally determine a system of voluntary co-operation, suppression of any kind is technically disadvantageous and merely 
offers obstacles to production. Now in the course of the normal increase of population, the fertility of the last lands cultivated is bound to diminish until a limit is finally reached, when the quality of the soils on the margin of cultivation would, if the land were free, naturally determine a voluntary co-operation of labour. When this point is reached, the continucd suppression of the free land no longer constitutes a factor in technical progress, but must become henceforth an obstacle to further production, and the exigencies of an augmenting population only renders the retention of the compulsory system still more intolerable. Thus the ultimate effect of the suppression of the free land is to confine production within continually narrowing bounds. The first result is to curtail capitalistic incomes, and the ultimate extinction of the revenues is only a question of time. The day is, therefore, bound to come, when production can no longer proceed under the capitalistic régime. And, then, in order to avoid increasing penury, society will practically be compelled to re-establish free land, and accord to every individual the right to occupy as great an area as he can cultivate with his own labour. A voluntary system of co-operation will then establish itself spontancously upon the hasis of free ownership of the soil. This will constitute the only adequate cconomic form, and result at last in social equilibrium. ${ }^{1}$

To resume: we find ourselves confronted by two social forms that are radically opposed. On the one hand, there is the mixed association, which is based upon free land, and established upon the right of each individual to oecupy as great an area as he can cultivate with his own labour. This system involves an equal division of the product between the capitalist lahourer and the co-operating labourer, and constitutes a social form which excludes all chass differences, eliminates privilege, and does away with all manner of

${ }^{1}$ For the fuller development of the theory here outlined, we must refer the reader to our Analyse de la Propricti Capitaliste, Turin, Bocca, 1889. 
usurpation. On the other hand stands capitalistic ownership, which rests upon the suppression of the free land and the consequent exclusion of the mass of humanity from access to the productive capacity of the soil-an exclusion which is effected first through slavery and serfdom, then by the reduction of wages, and finally through capital's exclusive appropriation of the soil. Under this latter social form the collective product is divided into two great portions-the wages of labour and the income from property; and humanity is accordingly severed into the classes of the exploited and the exploiters.

The mixed association constitutes the final economic ${ }^{1}$ form towards which society is unconsciously tending; while capitalistic property, on the other hand, represents, in its successive phases, the several stages in this evolution, the long and painful process of elaboration from which the definitive economic organisation of humanity will one day emerge. The former system thus possesses a normal and absolute value, while the latter is of but historical and transitory importance. During the course of the ages the final economic form has only shown itself sporadically and in part. $U p$ to the present ${ }^{\circ}$ it has only appeared like an indistinct mirage upon the extreme horizon of evolution. But every phenomenon and every problem must be studied in its final phase, and in the last stage of its development. Thus, in order to properly appreciate the character of social evolution, to fathom the true nature of past and present conditions, and to trace their mysterious processes back to their original causes, it is essential for us to analyse this final economy.

Now all manner of usurpation and every species of conflict being absent from the final economic system, it is perfectly well able to persist by itself, without relying upon any extrinsic

"I may state here, once for all, that by the expression "final form" (forme limite de l'économic) - borrowing a term well understood by mathematicians-1 mean that form which represen's the last stage in the development of a phenomenon. 
supports. But capitalistic property presupposes the exclusion of the toiling masses from the possession of the soil, and must, therefore, be established by violence. It is accordingly maintained by virtue of two distinct processes. Economic means are requisite, in the first place, in order to enforce the continued suppression of the free land. The analysis of these methods pertains to political economy, and does not properly enter into the subject-matter of the present work. But in order to support itself, capitalistic property must furthermore have recourse to a series of, what we may call, connective institutions, whose special function it is to guarantee property against all reaction on the part of those excluded from the possession of the soil. The most important of these so-called connective institutions are: morality, law and politics. These great social phenomena may, accordingly, be regarded as organic products of capitalistic property-or property, at least, metamorphoses, and adapts them to suit its own ends. This is the point we have to prove, and we believe the reader who follows us through the investigations forming the subject-matter of the present work, will be convinced of the accuracy of our analysis. 
PART I.

THE ECONOMIC FOUNDATIONS OF MORALITY. 

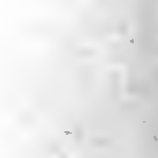


\section{CHAPTER I.}

THE MORALITY OF THE FINAL SOCIETY.

Let us suppose the existence of a free-land cconomy and its natural corollary, the mixed association of labour. What, then, would be the highest rule of human conduct and how could we be assured of its fulfilment; wherein, in other words, would the ethical sanction of such a system consist? The answer to this question is contained in the supposition itself.

The morality of the final organisation of society simply consists in the acts and abstentions that make for cohesion and social well-being. Individual egoism suffices as a motive, and no further sanction is necessary. By the very hypothesis, all acts injurious to social cohesion and collective well-being, all forms of usurpation between man and man, turn immediately to the disadvantage of the agent himself, and this of itself is enough to show him that such conduct is contrary to his enlightened egoism. The very existence of the mixed association implies that the society in question has already reached that stage in its development when the suppression of the frec land no longer aceords permanent advantage to the capitalist, as the limitations of production preclude the possibility of acquiring any revenue from capital. No one is, accordingly, inclined to suppress the free land in order to establish a capitalistic economy, inasmuch as he is aware that such suppression carries with it no lasting advantage. Under such conditions, therefore, economic usurpation is absolutely excluded.

But even if usurpation were not thus excluded in the agent's own interest, any attempt of one producer to injure another must at any rate provole an immeliate reaction injurious to the usurper himself. Indeed, under any economic system 
where men are free and equal, usurpation is both irrational and anti-egoistic; since it is bound to provoke a corresponding reaction rendering it harmful to the agent himself; but where the economy is associative in character the injury is especially marked. Thus the producer of capital who should endeavour to curtail the compensation of the ordinary labourer would only urge the latter to disrupt the association, thus in the end depriving his own labour of the power and efficiency accorded it by the association. And the result would be the same if the ordinary labourer should attempt to effect an unjust reduction in the compensation of the producer of capital. In like manner, any arbitrary attempt on the part of one class of producers to deprive another class of its legitimate influence in public affairs, would only offer provocation to the injured class to break up the association of labour, and this in turn would result in the ultimate injury of those instrumental in bringing about the original rupture. Thus a rule of justice emerges spontaneously from such a social organisation, originating in the enlightened egoism of all its nembers.

And over and above this purely negative function, expressed in the dictum, neminem lade, egoism also enforces the positive and nobler aspects of morality, summed up in the precept, imo omnes quantum potes juva. It is, indeed, but a natural consequence of the associative character of this final economy, that the kindness accorded a co-partner should accrue to the advantage of the benefactor himself. Thus the producer of capital who exhibits a kindly spirit toward the ordinary labourer, actually augments the productive activity of the latter, thus increasing the total product, and therewith adding to the portion thereof which reverts to him, the benefactor. And the same holds true of the acts of kindness performed by a producer of capital to his partners, and of the services rendered by the ordinary labourers to the producers of capital, or to the other workmen with whom they co-uperate.

In short, under an economic system where value is exclusively measured by the cost of production, and where no species of monopoly prevails, the favours conferred by one 
producer upon another accrue to the advantage of the former, as he in his capacity of consumer profits by the improved conclitions under which the goods he demands are produced. Thus, from whatever side we look at the matter, abundant proof is offered that individual egoism of itself suffices in the final society to determine a system of morality, assuring social well-being, and corresponding to the highest ideal of virtue imaginable.

Nor is the moral constitution of this final society in the least disturbed by the fact that the several producers may possess different degrees of physical and intellectual force. As a matter of fact, the present disparity in the physical and moral powers of individuals, is largely a bye-product of the capitalistic régime itself, and it may reasonably be expected that the prevailing inequalities among producers will be to a large extent neutralised under non-capitalistic conditions, but we have not to rely upon this contingency to support our contention. The associative character of the final economy of itself renders absolutely irrational all desire on the part of the strong to take advantage of their superiority, to the detriment of the weak; for any such attempt would only impel the weaker producers to retire from the association, and this in turn would render the labour of the strong less efficient, and consequently diminish the return formerly accruing to them. The better endowed may, indeed, protit from their superiority by producing more abundantly, and in obtaining in return a greater reward; but beyond this legitimate advantage, no further privilege is conceivable. Thus, instead of dissipating their forces in a uscless and sterile conflict with the wealier producers, the strong apply themselves exclusively to augmenting social production. Under such economic conditions, enlightened cgoism may even urge the strong to succour the weals, since the improved condition of the latter accrues to the advantage of the association, and consequently to the strong themselves. Thus not through a spirit of disinterestedness, but simply in accordance with the law of self-interest, the strong naturally devote some of their energies in rendering assistance to co-producers less fortunately endowed. 
Thus granting a disparity of forces among the several producers, we are still led back to the same conclusion : under the supposed economic conditions egoism assures the fulfilment of the most scrupulous justice, and makes for general kindliness. ${ }^{1}$

${ }^{3}$ It is evident from the above that in order to prove that the ethics of love will be spontancously established within the final society, it is not necessary to suppose with Bellamy and other socialists, that egoism will cease to be active under this final economic régime, and that each will take pleasure in working for others. This would only be admissible under the supposition that the final society would succeed in changing human nature--a thing at least very problematic. The above demonstration holds good, however, without recourse to any absurd hypothesis. We have simply to take account of the fact that, within an economy where equality prevails, especially if it be associative in character, respect for the well-being of another is in conformity with the cgoism of the individual, because every injury and every benefit accorded to others inevitably reacts to the disadvantage or advantage of the agent himself. It is thus with good reason that Lange (Geschichtc des Materialismus, Iserlohn, 1875, ii., pp. 470-472) remarks that a morality founded upon egoism would prove both possible and effective in a society of equals. There is, accordingly, nothing strange in the fact that among peoples who know nothing of the inequality of wealth, morality is ruled by egoism, as for example, among the savages of Australia, where every useful act is reputed just (Letourneau, Evolution de la.morale, Paris, 1887 , p. 172). Hobbes was, therefore, absolutely in the wrong when he conceived the natural state of man to be the war of all against all; for, within an economy where equality prevails, the reciprocal limitations of individual desires must, on the contrary, determine universal peace. 


\section{CHAPTER II.}

MORALITY IN THE CAPITALISTIC SOCIETY.

$I F$, after having analysed the ultimate conditions of economic evolution, we now turn our attention to the process of development, we shall readily perceive that during these unperfected stages individual egoism dictates a very different rule of conduct. Where the free land is suppressed, society no longer constitutes an aggregate of economic equals, but becomes divided into two distinct and separate classes: one composed of men deprived of their liherty of choice and obliged to work for their living, and the other made up of men with the privilege of living without working-and this latter class is again split up into a number of sub-classes and groups.

During these unperfected stages of economic evolution, a group of men may suppress the free land to advantage and establish thereon their economic superiority. Usurpation becomes thus useful, and, therefore, rational. The strong, who in the free-land economy were unable to take advantage of their strength to the detriment of the weak, may now use force to exclude the weal from the posscssion of the soil, since from such usurpation they acquire a large and lasting profit. And after having violently suppressed the free land the victorious class may continue to exercise its egoistic instincts in a limitless manner at the expense of the vanquished; for the latter are no longer able to free themselves from this relation of subjection by disrupting the compulsory association of labour. Among a society of equals such offences are impossible, since every man is opposed in the exercise of his own egoism by the egoism of his fellows; but when equality no longer prevails, and society is divided into two classes, the egoism of the masters is given free rein and nlay go to any 
excess at the expense of the slaves, because such acts of aggression assure definite advantages to their perpetrators, and there is no longer any fear of retaliation or of refusal to work on the part of the disfranchised. The result is that individual egoism now, for the first time, provokes a series of acts which are distinctly injurious to the greater number of society.

Usurpation also becomes possible in the midst of the proprietary class as well, on account of the disparity of wealth prevailing among the members of this group-a disparity which allows large owners to realise on appropriations and abuses at the expense of the small. But the relations existing among proprietors do not at all resemble those of which we have just been speaking, where some persons possess all the power and others have none, and where rebellion being precluded, domination is the only relation possible. They differ likewise from the relations which prevail in the mixed association among individuals endowed with an equal amount of economic force, and between whom, consequently, all strife is impossible-or, in any event, sterile. They are rather the relations which grow up between individuals who are independent of each other and yet equipped with different economic resources, and placed, accordingly, under conditions where mutual antagonism becomes at once possible, and, at the same time, fruitful in its results.

This competition among proprietors, unequally endowed with economic force, necessarily leads to the encroachment of the stronger upon the weaker; but such usurpation always finds its limit in the strength of the competing proprietors, and in the organic conditions of property itself. The less powerful proprietors-and herein they differ from the labourers-can, to some extent, prevent the aggression of the strong, by uniting their capitals and thus mitigating their economic inferiority. Such is the first check imposed upon the conduct of the larger proprictors in the interest of the smaller. Another no less efficacious check arises from the fact that the inherent conditions of property render it impossible, or at least, very difficult, for proprietors to carry out any such plan of mutual encroachment. To this we may add, that proprietors, great and small, are handed together politically, to form the state, 
and in their own interests, they are therefore not inclined to be implacable in their reciprocal usurpation. Thus, though the egoism of the proprietors may follow its extreme bent in its manifestations against the proletariat class, whenever it attempts to exert itself in the midst of the proprietary class, it finds powerful obstacles in the strength of the competitors cngaged in the struggle and in the organic conditions of property.

But if labourers and small owners can neither frustrate the efforts nor prevent the usurpations of capitalists and large owners, what is to prevent them from having recourse to the ultima ratio of the oppressed-insurrection? If the labourers cannot forsalke the capitalist because the free land is suppressed, why do they not rebel and break down this economic system which oppresses them? $1 \mathrm{~s}$ it not perfectly clcar that the labourers would naturally endeavour to revolt against this violent suppression, and is not their acquiescence in such suppression therefore in direct contradiction to their most elementary egoistic instincts?

Far from ignoring these problems, the capitalistic class has solved them with marvellous adroitness. To this end, capital first has recourse to methods essentially economic in character. By enrolling unproductive labourers on its side, and by making parasites of a number of its hirelings - who, with nothing to do, are still richly paid, and therefore interested in defending the property system-capital renders of less avail the numerical superiority of those excluded from the possession of the soil. But such means of themselves are inadequate to offset the numerical superiority of the labourers, and prevent a revolt on their part, which by virtue of their very numbers must necessarily prove successful. The capitalistic class resorts ac-

1 Maine (Ancicnt Law', p. 243 ff., Henry Holt \& Co., N.Y., 1888) asks how the respect for property entered into the human mind, and answers that it was developed as the result of time and tradition. But it is perfectly clear that such an answer explains nothing, as there still remains the yuestion of its original appearance. For, even before the element of time had come to militate in its favour, property was still respected by non-owners, whose very self-interest must have urged them to violate it. 
cordingly to a more decisive method, whose application is again entrusted to the unproductive labourers. The means employed are no longer material in character, but marked with a moral impress. The unproductive labourers, who have no other effective occupation, are now employed in giving a false direction to the egoism of the subjugated classes, and in perverting the calculation on which it is based. This is effected by setting up a fanciful moral sanction over against the labourers' revolutionary tendencies, causing the disinherited classes to dread the idea of revolt, and to look upon rebellion as more abhorrent even than submission. In this way, the bearing of the proletarians toward their masters (and the same may be said of the attitude of small owners toward the large) comes under the discipline of a moral law, which is exactly calculated to pervert their egoism, and render them tolerant under capitalistic usurpation.

But it does not suffice to proceed against the oppressed classes alone in such a way as to render reaction on their part less probable; it is also necessary to persuade the proprietors themselves not to push their policy of usurpation to the point of provoking the downtrodden classes to revolt in spite of themselves. The conduct of capitalistic proprietors toward the poor and toward small owners has likewise to be disciplined by a series of checks in order to prevent them from going to excesses, endangering the very existence of capitalistic property. It may seem at first as though no sanction were necessary to induce the large proprietors to assume a proper attitude toward the poor and toward the smaller proprietors, as such conduct is really in direct conformity with their enlightened self-interest. But such is not the case. It is true, egoism suffices of itself to direct human conduct so long as the results which it entails are evident and recognised beforehand. Thus, for example, in the society established upon free land, egoism is, of itself, quite enough to prevent aggression, as it is perfectly evident that the immediate effect of any such attempt would be injurious to the agent himself. But the society founded upon the suppression of the free land differs from the free-land society in that social relations are in the latter case 
unconscious and the agent remains ignorant of the results of his acts. Another fact must also be taken into account in this connection, namely, the possibility afforded by the suppression of the free land of allowing the injury resulting from an action to fall upon other shoulders than those of the person who commits it. In a social economy based upon free land an injurious action reverts at once, and without any possibility of mistake to the disadvantage of the perpetrator, and selfinterest urges him accordingly to abstain from like acts in the future. But an evil act perpetrated within an cconomy where the land has been appropriated only reacts upon him who commits it after a complicated series of repercussions which make it impossible for him to comprehend beforehand the injurious nature of the act that he commits and the consequent neces. sity of abstaining therefrom. This very complication of capitalistic relations furthermore allows the agent to shift upon others the injury resulting from his own acts, and thus renders his abstention still less rational and essential. As a result, egoism no longer suflices of itself to restrain the conduct of proprietors toward the poor and toward other proprietors within fixed bounds. It has, therefore, to be curbed and held in check by means of a morality which represents, as producing some fancilul injury, the act whose real evil effects are beyond the ken of the agent. Thus the same sort of moral coercion as is necessary to induce the poorer classes to adopt a line of conduct contrary to their real cgoism, is found to be equally essential in leading the richer classes to follow a line of conduct which is indeed at variance with their apparent, conscious and immediate interests, but which conforms unconsciously and indirectly with their real esoism. Thus it happens that we are witnesses of this strange and, at lirst sight, incomprehensible spectacle of a class constrained to act according to its own interests.

We are accordingly obliged to recognise that the relations existing between large owners on the one hatnd, and labourers and small owners on the other, give rise to a twolold moral code: there is the ethics of obedience instilled into the minds of the subjugated classes, compelling them to act in conformity 
with the interests of the rich; and there is the capitalistic morality which, while permitting the most pitiless usurpations, still prevents such excesses as might lead to a revolt of the oppressed, and thus undermine the property system.

But what is the nature of the moral force which thus compels the proprietary classes to act in conformity with their real interests, and at the same time forces the poorer classes to conduct themselves in a manner diametrically opposed to theirs? To understand the nature of a moral force of this kind, which is essentially psychic in character, it is first necessary to examine the psychological influences exerted by the suppression of the free land; for it is clear we cannot understand the workings of a machine until we know the conditions under which it operates, and the materials upon which its activities are employed.

Now if we examine the psychological influences surrounding isolated or co-actively associated labour, we find they reduce themselves to the following: First, labour, whose productivity is limited, either on account of its lack of association, or by reason of the checks imposed by compulsory association, is unable to dominate matter completely, and finds itself accordingly unable to effectually control the forces of nature. Second, this fact, taken together with the unconscious character of the social relations surrounding the individual, determines a sort of obsession of the mental faculties, and engenders a feeling of degradation and impotence, because he, as an individual, feels himself the victim of social forces, of whose ulterior tendencies he is ignorant, and whose processes he is unable to control. Third, the necessity of reconciling the social conscience to the existence of economic forms which are essentially corrupt, leads, by a systematic falsification of logic, to the institution of a settled sophism.

These three influences combined-and more particularly the first-result in a psychological phenomenon of extraordinary compass, namely, the idea of the supernatural. Recognising the futility of his attempts to conquer matter by his own labour, the human being is wont to regard nature's resistance in the light of a hostile force, as the emanation of a will 
superior to his own, which by prayers and offerings he seeks to render propitious. There is, indeed, nothing more natural than that the individual, who feets himself powerless to overcome the resistance of nature by his own physical force, should see in such resistance the work of a supernatural being, against whose might his own powers are dissipated, and whom supplications and sacrifices alone can appease;-nothing more natural, in other words, than that " the technically inadequate human economy, instead of endeavouring to perfect itself, should invoke the aid of religion. The priests by invoking rain can drive away the drought, wizards are able to cure disease, discover the whereabouts of criminals, and guarantee property against theft. The fetich directs the course of the lance and arrow if the hand of man be incapable." I It is, therefore, in no wise strange that the religious sentiment is thus developed as the psychological product of isolated or co-actively associated labour."

This explanation is moreover confirmed by the very remarkable fact that the sense of the supernatural becomes continually weaker, and religion becomes ever more rationalistic in character, as less and less restrictive methods are employed for the compulsory association of labour, and as the power of man over nature becomes greater in conscquence. Thus in northern countries where the greater resistance of matter necessitates, and accordingly evokes, the invention of extremely efficient productive methods, the co-active association of labour is effected by means which only limit production slightly. And it is in these very lands where man's power over nature has attained its most complete development, that religion has assumed a rationalistic character far removed from the superstitious forms of southern religions. Protestantism's triumph in Germany and England, and its failure to take root in Italy,

'Herrmann, Technische Fragen and Probleme der molernen Volkswirthschaft, Lcipzig, 1891, pp. 20-21.

${ }^{2}$ This psychic product of economic retitions is, indecd, normal; but still not necessary in every case. Hence there is nothing contradictory to our thesis in the fact, that people have been discovered absolutely devoid of religion. 
Spain, or any of the countries of the South, is also to be explained in this way. This great historical fact, of which Macaulay gives so mean an explanation-to wit: the powerful administrative organisation of the Roman Church! ${ }^{1}$-was the necessary result of labour's inferior ability to overcome the resistance of matter in these southern countries, and of the consequent greater intensity of the Southerner's feeling of impotence and subjection to occult and invincible forces.

But even though the obstacles confronting production continue thus to diminish as the economic system progresses, still, they cannot disappear entirely until the compulsory character of the labour association is destroyed, and a voluntary association of labour, based upon free ownership of the soil, is established. Only with the advent of this final social form, therefore, will the idea of an irresistible power superior to the forces surrounding mankind ultimately disappear, and therewith also the religious sentiment, which is its natural corollary.

We see, thus, how strangely those err who regard evil as a stumbling block in the way of religious belief; for, far from being in opposition to such belief, evil really constitutes its foundation. It is, in fact, these very social evils themselvesman's powerlessness over matter, his ignorance of the economic relations in which he lives, his constant fear in the presence of their undiscernible and mysterious processes-which together constitute the pedestal upon which the throne of the Godhead is erected.

We also see the mistake of those who, though they recognise a relation of do ut des between God and man in modern religions, fail to take account of the same in the religions of the past. ${ }^{2}$ This characteristic is, in fact, common to all religions, since, in all, man is obliged to render supernatural beings propitious in order to obtain their aid and support. ${ }^{3}$ The only

'Macaulay, Critical and Historical Essays, London, 1883, "Essay on Ranlre," p. 560 ff.

${ }^{2}$ Cf., e.g., Gibbon, History of the Decline and Fall of the Roman Empire chapter $x v$.

${ }^{3}$ The Romans worshipped the gods solely to gain their support (Marquardt, Römische Staatsaltevthümer, Leipzig, 1878, iii., pp. 53, 255 fl). In 
difference among the divers religions consists in the fact that, in some, this alliance is simply sought during the life on earth, for the visible struggle between man and nature; while other religions fancifully prolong human life beyond the tomb, and invoke Divine goodness and generosity for an ulterior existence as well. Thus the pagans of antiquity sought to render the gods propitious before proceeding with either war or the harvest-the two great functions which characterised their social life-but they accorded only scant importance to the future life, which (among the Greeks at least) was regarded as a privilege reserved for eminent personalities. Nor was it otherwise with the religion of the Jews, who were wont to call upon their God as an ally in battle, as the dispenser of the harvest and as the giver of hcalth and material prosperity. In the Christian world, on the contrary, we invoke the Divine alliance not merely for the vicissitudes of this temporal life, but also for the contingencies of an obscure hereafter.

This concept of a life beyond this world will be found, however, on closer examination to be but a natural filiation lengthily elaborated of the primitive religious idea. Having personified the adverse forces of nature and identified them at will with one or more supersensible beings, the human mind

primitive times, religion simply consisted in an exchange of serviees be. tween men and the gods. The altars themselves were nothing but tables luaded with meat-offerings to the gods, and a perfect correspondence prevailed between that which one asked of the gods and that which one gave them. The offering, in other words, corresponded to the importance of the request (Guyalo, L'irreligion de l'arenir, Paris, 1886 , ch. ii.), and things were not very different in an age more nearly approaching our own. "He who speaks of religion, speaks of wealth," wrote Scipione Ammirato, the Florentine canon, "and the reason is very simple. Religion being a separate account which one keeps with the Scignetur Dich, and we mortals being obliged to apply to him in many events, be it to return thanks to him for benelits received and evils avoided, or to pray him to spare us from this or accord us that, it is necessary in either case, whether it be as solicitors or as recipients, that we part with our goods, not to the God of the Universe who needs them not, but to his temples and his priests" (Opus D)isc. 7). The do wt des relation between man and God assumes a brutal character in modern Russia (Leroy-Beatulieu, "Sentiment redigieux en Russie" in the Rinne des dew.x momlis, 1877). 
then passed on to a fantastic conception of these creatures of its imagination, and elaborated in fancy their mode of life and their attitude toward human beings. In appointing the reciprocal relations among these supernatural beings, the mind naturally co-ordinated them in a series which faithfully reflected the human hierarchy and reproduced in heaven all the castes and class distinctions by which the earth has so long been dishonoured. Thus among the gods as well as among men, there are the great and the small, nobles and plebeians, the rich and the poor, freemen and slaves. ${ }^{1}$

The connection established in this life between gods and men consists in rewards and punishments, on the one side, and worship on the other. And these relations between mankind and the Godhead, in their turn, reproduce in a mystical manner the actual economic relations prevailing between man and man during different historical periods. Thus, during the pagan epoch, when labour's dependence upon property had its origin in a brutal subjugation of the many by the few, the relation

1 " Primitive religions reveal a celestial pantheon fashioned in imitation of the existing social order. In the world beyond, the masses of the population are composed of the shades of men, while the aristocracy is made up of demi-gods, above whom again stands the sovereign, represented by the supremc god. In some states of Asia the people recognise one god even as they obey one king, and just as they can ask nothing of the king except through the medium of satraps and ministers, so they can demand nothing from their god except through internediaries or demi-gods. In China, likewise, a celestial hierarciny exists which is the exact reproduction of the earthly hicrarchy, and all the privileges of the upper classes are carried over intact into heaven " (Sicber, Essai sur la civilisation économiquc primitive, Petersburg, 1ss3, p. 409). In India the successive degrees of metempsychosis correspond exactly with the various existing castes. The elder Hartung (Rcligion der Römcr, Erlangen, 1836, p. 16) has made some very judicious observations upon the basis of the Roman religion, and upon its derivation from the social surroundings. We might compare our modern concept of God with the idea of the constitutional monarch or the president of a republic; while the God of the middle ages may be likened to the absolute monarch. The inverse proposition, that social relations are derived from religious institutions, has been upheld, among others, by Quinct (Le génie dcs religions, Euvres, Paris, 1869), and by Max Müller (Lecturcs on the Scicnec of Religion, London, 1870). 
between mankind and the Divinity was likewise derived from a primitive conquest, supposed to have been effected by the triumphant gods over all humanity and symbolised in the victory of the gods over the Titans. During the middle ages, on the other hand, when the relation between property and labour assumed a patriarchal character, the relationship between man and God was likewise rehabilitated in similar guise; and in the legends of this period we find the Redeemer represented in the garb of a feudal lord with the Apostles as his vassals and mankind as his serfs. Having gone thus far, it was natural that the imagination of man should prolong the relations thus established beyond the grave. The mind which admitted the existence of immortal beings could likewise conceive of man himself surviving the tomb. It was, therefore, in no wise an extraordinary idea that the men who worshipped the gods during this earthly life should be reunited with them at their death and go to dwell with them in a world beyond.

Thus religious ideas, however elaborate and complex, are all derived from the original feeling of impotence that the human being experiences before the forces of nature; and this sentiment, in turn, is the historical product of either the nonassociation or the compulsory association of labour. Such is the psychological basis upon which capitalistic society has been able to elaborate its methods of coercive morality. Now, given such psychological conditions, with their resulting mental phenomena, the means of moral suasion which society has at its disposal, evidently reduce themselves to the following: fear, religion and public opinion.

The first and third methods are easily explainable. They rest upon the timidity and discouragement resulting from isolated or compulsorily associated labour, which cause the human mind to readily submit to the influences of the social environment. Men are thus forced to act in a manner contrary to their own interests, either by means of the semblance of power with which the dominating class surrounds itself, or by virtue of a system of imaginary penalties which fall, or appear to fall, upon those who do not act according to the rules laid down hy this class. But the second process 
is not so easy to understand. Religion, in the sense of an invocation of Divine aid through prayers and offerings, does not of itself imply morality. Morality is a relation between man and man; religion is a relation between man and God; and these two relations may very well be disconnected and exist independently of each other. This is so true that in many religions the moral element is absolutely lacking. By means of sacrifices, the Godhead is in such cases rendered propitious to material life in general, and to production in particular; but there is never any thought of gaining his good-will by following a line of conduct determined by purely human relations. But though religion is thus not necessarily accompanied with moral sanctions, it may, nevertheless, be made to serve as an excellent instrument of moral coercion. It is sufficient for this purpose that the performance of acts which are opposed to one's interests be represented as necessary in order to render the Divinity propitious, and avoid his anger and chastisement. The means of acquiring Divine favour have, in other words, simply to be so extended as to include not merely man's acts of reverence to the Deity, but also a series of actions determined by the relationship of man to man. In this way God becomes, as it were, the capitalist of heaven, crediting men with the good actions performed during their life-time, and paying them a proportional salary either in this life or in the life to come. Thus the fear of Divine punishment succeeds in doing violence to the egoism of the individual, deterring him from acting in conformity with his own interests, and impelling him to acts which are opposed to his own, but in conformity with the real egoism of his oppressors.

Let us now see how these three means of moral compulsion have been applied under the different economic systems.

In the primitive economy where individuals are compelled by some despotic power to co-operate-but for the good of the labourer himself, be it remembered, and not at all to the advantage of the private capitalist-moral coercion is applied with a view toward forcing men to act in conformity with their real interests, of which they, indeed, are unconscious, but which, in reality, demand the conjunction of their forces. A 
code of ethics adapted to such conditions is developed by means of a series of penaltics, pre-eminently religious in character, which are imposed upon all acts conformable with man's apparent egoism that tend toward disassociation. We find examples of such sanctions in the internal life of primitive communities like the mark or the clan, whose really pure and elevated morality is entirely directed toward assuring reciprocity of services among the members of the community, and toward strengthening the bonds of an association which the individualistic instincts of men might tend to break asunder. ${ }^{1}$

But of still greater interest is the study of the ethics of savage communities where the relation of individual subjection only exhibits itself in a partial way. The morals of such societies, whose members are all free, equal and independent, should be spontaneously determined by an egoism scarcely enlightened by a dawning intelligence; for though, indeed, the lack of association precludes any egoistic impulse toward benevolent acts, the very conditions of equality at least create egoistic motives for abstaining from malevolent acts, which would provoke an immediate reaction and thus turn to the disadvantage of the agent himself. But the necessity of moral coercion is likewise imposed upon these primordial communities by the existence of domestic servitude, which can only persist when one entire class, or one sex, is constrained to perform acts, or endure treatment contrary to its enlightened selfinterest. Now the savage woman's acquiescence in servitude of this kind can only be obtained through a systematic perversion of her egoism, representing tolerance and docility as in conformity with her interest. And the man has also to contain himself somewhat in his acts of violence toward womankind, for in overstepping the prescribed limits he will surely provoke a reaction on the part of the oppressed sex.

'Cf., e.g., Maurer, Gr'schichte der Dorfocrfassung, Erlangen, 1862, i., pp. 328-40. Prince Krapotkine rightly insists upon the purity of morals in primitive socielies; but he fails to note llae coercive chatracter of such morality and its dependence upon the co-active nature of the economy' ("Murual Aid among Savages," in the Ninctenth Century of April, 1891. Id., "Among Barbarians," ibid., January, 1892). 
But these bounds cannot be spontaneously determined, as the naturally egoistic man, seeing nothing beyond his own immediate advantage, with difficulty comprehends the importance of curbing his own desires. Limits have therefore to be imposed upon the egoism of the dominant sex by means of an imperative sanction. Thus the introduction of a supernatural code of morality becomes necessary in order to hold the oppressed class to a line of conduct contrary to its real egoism, and to force the dominant class to act at variance with its immediate interest.

With this in mind, all those terrible prescriptions and superstitions that one meets with among savage peoples become at once intelligible. $U_{p}$ to the present these phenomena have completely baffled the sociologist, and have thus far only been explained by means of the most equivocal sophisms. Thus Wake regards the savage's code of ethics as a product of his egoism, pronouncing spontaneously upon the necessity of respecting the property rights in another's chattels and wife, in order that his own rights to chattels and wife be in like manner respected. ${ }^{1}$ But this explanation gives no account of the supernatural and imperative character of the savage's moral code, which indeed would have no raison d'être were the moral act simply the spontaneous product of individual egoism. To explain the supernatural character of the morals of the savage, Wake is therefore driven to take recourse in the following line of reasoning: First, he tells us that the ethical character of morality, or the idea of duty, is derived from respect for the departed, and the belief that the dead require vengeance for injuries received. Elsewhere he explains to us, how, on the contrary, man came gradually to admit that that which was socially injurious was likewise displeasing to the gods, and then to affirm that that which was displeasing to the gods was morally reprehensible. And it is from this last concept that the idea of duty arose, meaning thereby an act imposed upon the individual in opposition to his egoism. But in order to reach this difficult combination called duty, Wake also adds other still more complicated ingredients, as for

${ }^{1}$ Wake, Evolution of Morality, London, 1878, p. $293 \mathrm{ff}$. 
example: a chief of some tribe endowed with genius, custom and a host of other fine things which render truly laborious not merely the active formation but even the mere concept of moral duty. All these complications are explainable on the supposition that the author found himself in the presence of a society where the majority of the population was composed of free and equal individuals placed under the conditions most favourable to the spontaneous germination of egoistic morality, and that the existence of a subjugated class, which alone renders egoistic morality impossible, escaped his attention. But the moment we recognise that an oppressed class is present, even in savage communities, we must at once understand that this class's acquiescence in the existing order of things is really in opposition to its real interests, and that such acquiescence must therefore be effected by superior force, as it can never be spontaneous. The supernatural and imperative character of prehistoric morality can thus be explained very simply.

The points we are insisting upon come out still more clearly when we examine a society somewhat further on in its development, where oppression has assumed a more complete form, and become economic rather than purely domestic in character. Such are the characteristics of the slave-economy. Here the psychological and human element is practically lacking, and the labourer is reluced to the condition of a brute. His acquiescence in usurpation is accordingly assured through fear, which causes him to look upon revolt as totally incapable of securing him his liberty. An imposing system of moral oppression succeeds in malking the lahourer rcally believe that he is a slave by nature, that his chains have been forged hy a superior power, and that it is vain to strive to break them. This fiction, built up with the secular assistance of clients and liegemen, becomes so formidable in the minds of the oppressed, that they no longer dare to rehel against their masters, and bow instead before the destiny which condemns them to serve. Thus the usurpant egoism of one class, while assuring it enormous advantages, engenders as its natural corollary, the necessity

${ }^{1}$ Wake, loc. cit., i., p. $320-50$. 
of perverting the egoism of the other class, in order to induce it to endure in silence the injustice of which it is the victim. The necessary perversion is accomplished by investing the ruling class with an appearance of terror and almost superstitious awe, which exert an overwhelming influence upon the oppressed. The obligation thus imposed upon the capitalistic class of maintaining an awe-inspiring attitude in order to dominate the disinherited of the land, and the necessity of instilling fear into the oppressed, either by force or by a show of force, engenders that morale de l'épée, so common in the ancient world, whose leading characteristic is the cult of heroism. But the glorification of personal valour was a sentiment exclusively reserved for free men. For them alone force constituted the highest law, while for the slaves, passive obedience was the only alternative. And this, indeed, was imposed by every means upon the forsaken and suffering classes.

During the period of slavery moral compulsion was thus effected principally through fear, though not to the exclusion of the other forms of moral co-action that we have mentioned. Religion especially very often served as a cloak to be assumed by the instrument of terrorism, in order to assure the preservation of the slave society. Thus the Jewish religion included nothing beyond a series of threats of earthly ills wherewith God frightened men, and prevented them from performing certain acts that were socially injurious. The pagan religions likewise threatened the violators of social peace and its system of organised oppression, with countless evils. These primitive religions succeeded much better, however, in restraining the excesses of proprietors among themselves or toward their slaves, than they did in checking revolts among the slaves. This, indeed, was very natural; for how, indeed, could these religions be expected to exercise any moral force upon the labourers? How could they possibly reconcile the labourers with their present misfortunes, when they looked upon the future life of man as but a continuation of his terrestrial existence, and thus offered the slave no other outlook beyond a perpetual bondage in the world to come? Far from instilling 
a spirit of docility and obedience in the souls of the oppressed, such religions could only have the contrary effect of urging the oppressed to revolt; since, were they successful according to the dominant belief, they would ameliorate their condition, not only in this life, but also for all eternity. ${ }^{1}$

During this phase, religion was, accordingly, not of the quietive kind, but rather revolutionary in character. Hence, social statics could never make use of it as a means of morally coercing the subjugated classes. Religion did not appeal to the slave's heart, nor did it so much as attempt to mould him in meekness. On the contrary, religion then addressed itsclf solely to the proprietary classes, since, as Aristotle plainly said, the gods could only be worshipped by freemen, a civibus enim deos coli decet; ${ }^{2}$ and this, indeed, had the happy result of tempering and facilitating the relations prevailing among proprietors themselves. ${ }^{3}$ Thus they were wont, for example, to call upon the god Terminus to protect their possessions-that is, to defend one proprietor from the usurpations of another. Divine sanction was also necessary to assure the validity of the given word, the binding nature of an oath, and all matters pertaining to the family and inheritance. Even the theoretical ethics of this period-and it is again Aristotle who makes the assertion ${ }^{4}$-had only to do with free men. To them it, indeed, counselled kindness in their reciprocal relations, but, at the same time, it allowed the perpetration of flagrant outrages upon the enslaved labourers, and even proclaimed the abjection of the latter to be in conformity with nature.

In slave societies the dominion of the morality of fear thus operated very differently upon the proprictary classes and the labourers. By threatening free citizens with the wrath of gods

'Sieber loc. cit., pp. 410-11.

2 Politica, vii., 9.

${ }^{3}$ This was not always the case, however; as the Roman religion, for example, served for a long time as a means in the hands of the Patricians of oppressing the people, and consequently aided in aggravating th: confict between the two classes (Gaston Boissier, La ríligion romainc, Paris, 1884, i., p. 40).

'Loc. cit., vii,, 8. Denis, Mistoire' des thérie's et de's idécs moralis dans l'antiquité, Paris, 1856, i., p. 220 ff. 
and men as a result of their excesses or their faults, this ethical system succeeded in instilling a spirit of kindness and equity into the reciprocal relations of proprietors, and, at the same time, prevented them from exercising such cruelties toward their slaves as might have provolied them to revolt. In other words, it imposed actions upon proprietors which were really in harmony with their egoism, although they themselves were unaware of the fact. On the other hand, it held the slaves to obedience by giving the dominating class an awe-inspiring aspect, and thus succeeded in directing the actions of the oppressed in a manner contrary to their real egoism. ${ }^{1}$

These ethics of fear, which prevailed in classic antiquity, are necessarily reproduced whenever the economic or geographic conditions recur upon which they were based. They reappeared, accordingly, in Christian America, where slaveowners committed, under the auspices of the Gospel, the most iniquitous outrages against their negroes, and lept them in subjection by assuming a fear-inspiring attitude. They have come to light again in our day in Erythrean Africa, where we Italians have become sanguinary creatures, conquerors and violators of female slaves; and where we pooh-pooh the morals of pity and love, in which we affect to believe at home, in order to establish a very different ethical code, that of orgy, rapine and slaughter.

As we pass on to a consideration of the serf-economy we find the ethical system undergoes a radical change, presenting still more interesting phenomena. Moral suasion is still applied to the capitalists, to lead them to act in opposition to their conscious interest, as well as upon the labouring classes, to force them to act contrary to their real interests; but the methods of such compulsion are completely changed.

${ }^{1} \mathrm{La}$ Boëtie is right up to a certain point when he declares that slavery is only possible when the slave himself desires it, because if he did not wish to remain a slave, no human force could hold him in bondage. But the ingenuity of the capitalistic system shows itself just here, in its cnuployment of psychological methods which vitiate the will of the slave, and make his acquiescence under the yoke which oppresses him appear desirable. 
Acts that are socially injurious are now threatened with punishment in the life to come, and a dread of the future is thus made to take the place of present fear. Such was the great capitalistic function performed by Christianity. A religious sanction was thus introduced for the first time as a means of moral co-action and as a safeguard to property. In this regard Christianity transcended the ancient religions, which were incapable of attaining such social ends. In fact, the terrestrial sanctions with which these older religions threatened immoral acts, very often failed to be realised, and this, in the long run, weakened the power and influence of the entire ethical system. By carrying the sanction over into the future life, Christianity, however, removed this assurance of impunity, and consequently, precluded any reliance upon the emptiness of the threat. Armed with an anathema that was invisible in its results, whose decrees one could neither criticise nor avoid, Christianity accordingly addressed itself to the labouring classes, and dictated to them a series of acts in opposition to their egoism, threatening those who would not obey with terrible punishments in the world beyond. The serf's resignation under such subjection was furthermore assured, with even greater efficacy, by means of that fecund dogma which taught that the gates of heaven were only open to the poor. Thanks to this doctrine, the serf came to look with a smile of contempt upon the fleeting fortunes of the rich, which were to exclude them from the delights of eternity, believing his present submission would be rewarded by a crown of glory, and with felicity in the life to come. This inverse relation between terrestrial happiness and future felicity-which was entirely unknown to the ancient religions, and indecd, antithetical to them-became a very powerful instrument for reconciling the unfortunates with the system which exploited them, and constituted the most deserving claim that Christianity acquired among the dominant classes. ${ }^{1}$

${ }^{1}$ Gladstone ("Ancient Belief in a Future Life," in the Ninetenth Century for October, 1891), observes that belicf in a fulure life was characteristic of the Jews, the Persians, and more especially the Egyptians, and that it was just this which constituted the strongest sanction and the most 
With its dogma of charity, this new religion addressed itself no less efficaciously to the ruling classes, and directed their acts in conformity with their real interests. The self-interest of these classes, indeed, demanded that they should look with care to the well-being of the labourer in order to avoid all danger of a revolt on his part, and in order that productionwhich had practically been brought to a standstill through slavery-should receive a fresh impulse. But the Christian religion went further, and spoke also to the hcart of the rich, imposing upon them the duty of alms-giving, as the only means whereby a man, deprived of the passport of poverty, could enter the kingdom of Christ and take part in future felicity. This religion also sought in the same way to contain the intercourse among proprietors themselves, within definite bounds, and prevent all such extremes of violence as might compromise the persistence of the property system.

But this same religion which took such care to check all acts injurious to proprietors, gave free scope to the most unbridled usurpation, provided it was not of such a nature as to compromise the capitalistic system. Hence the opportunity for those infamous offences committed during the entire middle ages under the auspices of religion. Christianity

severe discipline of moral conduct among these people. It is nevertheless true, that it was left for Christianity to elaborate and perfect this belief, by adding to it the idea of an inverse relation between the present and future condition of the bcliever. The religions that preceded it had nothing like this in their doctrines. Buddhism is completely without the conception of a future life. The Finnish infernal regions, like the Greck Hades and the Scandinavian Niflheim, have nothing of the significance of a place of punishment (Comparctti, Memorie dei Lincei, viii., p. 91). The conception of God's primitive function in the world to come only began to appear within the Roman religion in a confused manner, and mingled with numerous restrictions and multiple contradictions (Boissier, loc. cit., p. $32 \mathrm{ff}$.). Hence Gibbon concludes: "We are sufficiently acquainted with the eminent persons who flourished in the age of Cicero, and of the first Casars, with their actions, their characters and their motives, to be assured that their conduct in this life was never regulated by any serious conviction of the rewards or punishments of a future state" (Decline and Fall of the Roman Empire, Milman Ed., 1883, vol. i. p. 528). 
permitted the feudal lord to muzzle the tired serf who ground the corn, that he might not convey a morsel of the flour to his mouth. The religion of the day put no check to the acts of violence, the massacres and the rapine that so long scourged Western Europe and Asia. It tolerated the warfare waged by Christian capitalists against their Jewish rivals in medixval Europe (as it does to-day in Russia where the same conditions are historically reproduced), and lent finally its sanction to the most ferocious orgies of blood. And why? Macaulay, with his habitual clegance of style which skims over the surface of things but ignores their real depth, attempts to explain the morals of Machiavelli's century as the product of mercenary armies; ${ }^{1}$ but Adam Smith accords them a much more studied and complicated interpretation. ${ }^{2}$ According to the latter author, at this time when great crimes were habitual and went unpunished, they involved no lack of discretion-a vice which public opinion censured above all others during this epoch-and they were consequently tolerated and even universally encouraged. But this explanation appears at a glance both superficial and absurd; for the question still remains as to why, during so long a period, great crimes were thus habitual and succeeded in escaping all punishment. Society's toleration for great crimes is always explainable from the evident fact that all moral and legal sanctions are of no avail against those who are audacious enough to commit them ; but, the real and decisive reason is, that crimes of such a nature instead of compromising the property system, are in fact its normal and necessary outcome, and even constitute one of the indispensable conditions of its existence. Thus Machiavelli's enthusiasm for Cassa. Borgia is only intelligible to one who has grasped the true nature of feudal property, and understood both the inherent necessity of the spoliations, extortions and crimes which characterised its career of violence, and also the historical justification of the acts that favoured the persistence of this dominant social form. In the same way,

${ }^{2}$ Macaulay, loc. cit., "Essay on Machiavelli," pp. 28-31.

"Adam Smith, "Theory of Moral Sentiments," in his Essays, World Ed., p. 192. 
the persecution of the Jews during the middle ages was tolerated and even instigated, because it was rendered necessary by the reaction of feudal against personal property. And modern society's indulgence toward the coup d'état is, in like manner, due to the fact that the change tends to fortify and favour the development of capitalistic fortunes rather than to endanger their solidity.

Thus during the entire feudal period, religion constituted a powerful organ of moral co-action, ${ }^{1}$ imposing upon the proprietors certain acts that were contrary to their conscious interests, and upon the labourers certain acts that were in opposition to their real interests. ${ }^{2}$ But with the appearance of the wage economy, which succeeded in freeing the labourer from his material and intellectual bonds, the influence of religion was impaired and it ceased henceforth to be a reliable means of perverting egoism. Voltaire, it is true, continued to make vows in order to preserve faith in God so that the tenants might still pay their rents and obey their lords. And Kant, too, after having dethroned religion in the name of pure reason, immediately re-established it in the name of practical reason, in the belief that the postulate of the Deity was necessary for the recognition of the moral law. This latter theory, indeed, corresponds very closely with the spirit of the feudal period-to which the Germany of Kant still belonged - which necessarily had recourse to religious beliefs in order to divert the masses from acting in conformity with their

${ }^{1} C f$. in this connection, Lafargue, Evolution of Property, London, 1891, p. 58.

2In speaking of Philippe le Bel, Sismondi wrote: "I1 savait que les prêtres étaient les meilleurs instruments pour assoupir les consciences et que, pour faire taire la morale, ils feraient parler la religion " (Histoire des français, Paris, 1837, ix., 177). Clamageran expressed himself thus in regard to the France of bygone centuries: "Les jouisseurs sceptiques faisaient, par nécessité, alliance avec les ecclésiastiques, dont ils avaicnt besoin pour tenir le peuple en buide " (Histoire de l'impôt en France, Paris, 1872 , iii., p. 207). Every church had its saint and each saint his tradition fabricatcd with a vicw toward enriching the churches placed under its protection (Lecky, History of Europcan Morals, London, 1869, ii., p. 230). 
interests. ${ }^{1}$ In Italy, likewise, Mamiani regarded religion as a means of coercing and disciplining popular feeling. And even in our days, the landed proprietors of East Prussia are urging that missionaries be sent out through Saxony with a view to suppressing the pretensions of the agricultural labourers who migrate to Saxony temporarily and bring back better formulated demands from this more enlightened country, and in the hopes of lulling earthly covetousness to sleep among these people by means of the precious narcotic of faith. ${ }^{2}$ There can be no doubt, in short, that, after all has been said in regard to Catholic and Papal socialism, religion and the Church still constitute to-day no mean factor in the persistence of capitalistic property.

Nevertheless, despite these posthumous attempts, we can henceforth accord religion but a secondary influence upon human actions, and we must therefore recognise that the conduct of the labouring classes has in otr day to be subjected to a more modern and potent method of discipline. This modern method of moral coercion is supplied through the influence of public opinion, which, by means of a series of psychological processes and adroitly inspired ideas, succeeds in rendering every act dishonourable which carries with it any menace to the property system, and thus prevents its commission. ${ }^{3}$ Public opinion requires the labouring man to

${ }^{1}$ Marlo, System der Wictockonomic, i., p. 347. Even Roseher himself (Naturlehe der Demokratic, 1\%90. p. 73) Jooks upon religion as a political means of holding democracies within bounds. The modern recrudescence of the Catholic idea is simply a reaction against the influence of irreligion which is disturbing the docility of the lower clatsses.

2 Kärger, Die Sachsingunertrei, Berlin, 1890.

${ }^{3}$ Bryce (The Americun Commontecelth, London, 1888, iii., p. 502) rightly observes that morality is the basis of social persistence in Americat, and that social cobesion is there maintained hy the acyuiesence of the majority in the existing oreler of things. However expedient this state of things may be for Ameriea, this author allows us to see that he does not believe it to be adiptable to Europe, where the physical force of armed men suffices, in his opinion, to mainsain order among the popular classes. But we may be permited to ask why these amed men, who belong for the must part to the disimherited classes, do not refuse to perform this function whose purpose it is 10 holl these very classes in restraint; and why, indeed, they sonctimes go so line as to turn their 
acquiesce in the domination of capital. It appeals, indeed, to his intelligence, but only to warp his judgment, with a view of urging him to fulfil certain requirements which, though directly contrary to his own real interest, are nevertheless rendered attractive by the approbation of the well-born. ${ }^{1}$ Public opinion at the same time requires the capitalists to restrain themselves in their policy of usurpation within certain bounds, in order not to compromise the fate of the property system. Having become the despotic arbiter of judgments and deeds, ${ }^{2}$ public opinion now sets the seal of its disapproval upon the least reaction on the side of the labourers against the system which oppresses them, and yet it tolerates usurpation on the part of proprietors to the injury of labourers, ${ }^{3}$ and it even favours suspicious appropriations by one capitalist to the detriment of another, so long as such acts do not threaten the cohesion of the capitalistic system.

ar'ms against them ? This can only be explained through the medium of a moral influence which holds the popular classes in obedience, and either blunts the arms they hold, or makes use of them in defence of the dominant class.

${ }^{1}$ Religion has but little hold over the labourers. Legal punishments or "the fear of losing universal esteem prevent them from falling into bad ways, or sinking into immorality" (Commission du travail. Réponses, Brussels, 1887, n. 1008). Romagnosi (Genesi dol diritto penale, part v., chap. iii.) insists upon the efficacy of a good reputation and the standards of honour as means of preventing social disorders. Such sanctions are, nevertheless, always inspired in the interest of the dominant class, and are always designed to misrepresent the egoism of the subjugated classes. They are, moreover, only possible when these classes are sufficiently educated and eivilised enough to be susceptible to moral influences. For the grosser and more stupid labourers, on the contrary, it is necessary to have recourse to material punishment. Thus in Venetia, "the peasants fulfil their obligations in the firm conviction that they must yield to force" (Morpurgo, I contadini nel Veneto, negli atti dell'inchiesta agraria, p. 50. Cf. Schopenhauer, Le fondement de la morale, Paris, 1888, p. 97).

${ }^{2}$ De Toqueville and John Stuart Mill both make judicious observations touching the tyranny of the public opinio a our day.

${ }^{3}$ The attitude of the Irish landlords toward their tenants is the negation of that Christian morality they profess with such fervour (Cairnes, "Fragments on Ireland".in his Political Essays, 1873). 
What though the essence of modern morality be a sealed book to contemporary doctrinaires, it was no mystery to the theorists of the last century. And particularly was it no secret to the founder of the science of economics, who, on the contrary, proclaimed it aloud in his immortal work; for the theory of sympathy expounded by Adam Smith, corresponds admirably to the historical conditions surrounding the wage system, and the prevailing moral code that prevails therein. This doctrine which teaches that human actions are determined by a desire to please the spectator-a theory, by the way, only qualified apparently to develop a race of charlatans-is, in fact, but a brutal representation of our own morality, subjected as it is to the capricious judgment of public opinion. It is still but a superficial representation, however, which does not go back to the causes that so strictly determine this verdict. ${ }^{1}$ it does not explain on what grounds public opinion favours certain acts with its sympathy while it condemns others, nor does it determine the motive that guides the current of sympathy and inspires the decrees laid down. All this must remain without adequate explanation so long as we fail to trace moral phenomena back to their final cause in the egoism of the capitalistic class. This is the spirit which silently inspires public opinion, and uses it to impose certain acts upon the proprietary classes that are in conformity with their real egoism, and upon the labouring classes certain other acts which are in contradiction to theirs.

It is because he failed to take account of the essentially capitalistic character of morality that Adam Smith was never able to comprehend the cocrcive nature of the morals of every epoch. If it were true that a natural instinct urges every man to perform acts calculated to arouse the sympathy of the disinterested spectator, why then was it necessary to have recourse during so long a period to religious suasion, in order to induce men to perform acts which universal sympathy would have applauded? Why does there exist so large a number of individuals, even in our modern societies, who are loth to act

1 "La sympathie est le symptime, non la cause de la moralité d"une action" (Cousin, Préface ì Simith, Richesse des nations). 
in conformity with public opinion, and must therefore be compelled to do so by material force? And why, in any event, should men perform deeds that are agreeable to others rather than those that are pleasing to themselves; why, in other words, should the motive of man's acts not be self-interest rather than sympathy? The theory is still more strange, emanating as it did from this writer, who was later to construct an entire system of political economy on the theory: that the egoism which develops without restraint from economic activity leads to perfect social harmony. If this were true, egoism ought of itself to lead to conduct which would assure social equilibrium without it being necessary to have recourse to an external sanction, the sympathy of the multitude, in order to bring about this result. But we may go still farther. Smith himself had a number of luminous observations to make upon the influence exerted by association, in rendering benevolent acts conformable to the interest of the agent; and he remarked that it was only in the commercial society-which is essentially disaggregated-that such conformity suddenly disappeared. ${ }^{1}$ This amounts to saying that, under social conditions different from our own, there existed a code of morals which, instead of being grounded in the sympathy of the spectator, was rather identified with the real egoism of the individual; that under the modern social organisation, the real egoism of the individual cannot conduce to moral acts, simply because the very ensemble of relations in the midst of which it operates, makes usurpation or rebellion more in conformity with egoism than benevolence; and that for this reason alone, the individual must be led to benevolent acts, by means of a compulsory morality which vitiates and artificially perverts his egoism. Such coercionand here we are in accord with Adam Smith-is exerted in our day through public opinion; but only in our day, for, formerly, it had recourse to very different and much more solemn sanctions.

${ }^{1}$ Adam Smith, Theory of Moral Sentiments, p. 198. 


\section{CHAPTER III.}

\section{A COMPARISON OF THE DIFFERENT SYSTEMS OF MORALITY.}

Within the final economy established upon free land, morality will obtain its highest form, and become entrusted to the enlightened egoism of all the free and equal members composing the society. The ultimate cthical system is thus based upon self-interest, for in an economy composed of equal and freely co-operating individuals, the personal interest of each precludes ail acts that are injurious to others and encourages deeds of kindness. Individual utility, which constitutes the only test of human actions at this stage of social evolution, accordingly determines a line of conduct conducive to social happiness. For so long as each individual follows his own advantage only in so far as it does not interfere with, but rather favours that of others, then the well-being of the individual tends toward social well-being, and the free exereise of each man's egoism suffices of itself to assure the greatest sum of collective happiness.

Within an economy where the land is pre-empted, the egoism of those retaining their liberty of choice leads, on the contrary, to a line of actions prejudicial to the less fortunate members of society, who, in their turn, are thus urged to rebel. In order to assure social cohesion under conditions so menacing as these, it is therefore necessary on the one hand to deter the capitalistic class-and that too in its own interest-from excessive usurpation, and on the other hand to lieep the lahouring classes from revolt. This latter result is attained hy so vitiating the labourer's egoism that the part of temperance and acquieseence appears to him, by a sort of mirage, $t$ o be in greatest conformity with his interest. Moral suasion of this nature was first effected in slave societies through intimidation, which caused the pro- 
prietors, in their own interest, to refrain from making exorbitant demands, and at the same time prevented the slaves from having recourse to rebellion, which was really in conformity with their interests. Later on, in the feudal society, the same ends were effected through religion, and in our modern wage-societies by means of public opinion.

Spontaneous morals, having their root in pure egoism, belong thus exclusively to the final economic form. During the capitalistic stages we find, on the contrary, an imperative code of ethics based upon a series of psychological, religious and social imperatives which restrain the egoistic impulses of the capitalistic class and vitiate the egoism of the labourers.

On comparing these two basic systems of morality we find, first of all, that they exert diametrically opposite influences upon human character. So long as economic conditions of themselves dissuade the individual from dealing detrimentally with his fellows, his very powerlessness of doing harm and the personal injury incurred by a malevolent act, together cause a love of the good and a horror of evil to grow up in his mind. Thus the observance of pity and justice, though in reality imposed by egoism, gradually suffers the recollection of its origin to be lost and assumes an ideal character which makes of it a true virtue worthy of being practised for its own end and independently of the utility of its effects. On the other hand, under economic conditions where one man can seek his own advantage at the expense of another, usurpant egoism is allowed free rein and may accordingly abandon itself to the most terrible excesses against the subjugated classes. As a result, instead of an aversion for evil and a lofty cult of the good, we find a persistent and inhuman exploitation of the greater number by the privileged few. Thus the untamed ferocity of the master toward his slaves, ${ }^{1}$ and the cynical indifference of the modern

1 The brutality of Racine's Nero, which is voiced in the infernal speech, " $j$ 'aimais jusqu'a ccs pleurs que je faisais coulcr," was but the product of the slave-economy which allowed the greatest ferocity toward the slaves and even made it a necessary condition for guaranteeing the persistence of the capitalistic economy.. 
capitalist offer a sinister contrast to the gentleness of character and serene benevolence that characterise the pure economic form.

When confronted with the fact that human nature itself changes radically with a change in the economic conditions, those universal maxims, so dear to philosophers of former times, lose all their force. Nothing is, indeed, more erroneous than Rousseau's assertion that man emerged virtuous from the hands of the Creator, and only became evil and unjust under the influence of social institutions. And nothing again is more absurd than the contrary statement of Hobbes, that man by nature is the enemy of man. Neither assertion is true. Nan of himself is neither good nor bad, he is neither controlled by virtue nor by vice. A single sentiment guides him, one impulse drives him on: the instinct of self-preservation or personal egoism, which in its turn is nothing but one of the multiple manifestations of the conservation of energy.

But this fundamental instinct is in itself undetermined in its direction; it manifests itself in a manner either benevolent or malevolent, it urges toward justice or toward injustice, toward virtue or toward vice, simply in accordance with the economic relations under which it operates. If the economic constitution assures equality among producers, then all forms of usurpation are injurious to the agent, and hence his very egoism impels him to virtuous acts. If, on the contrary, there exists a class of men who are deprived of all choice and every means of defence, and conseyuently exposed to the most ruthless exploitation without the possibility of retaliating, then usurpation is advantageous to the agent, and in line with his egoistic instincts. This same egoism, therefore, which in the former case leads to goodness, in the latter leads to wiclicdness-to good and to evil, for which not egoism itself, but rather the conditions under which it operates are responsille.

Another antithesis, no less important, next claims our attention. Ultimate ethics are based upon the egoism of the individual, while capitalistic morality is inspired exclusively by the egoism of the dominant class. Thus the morality of the Chinese had its origin in the welfare of the family, that of the 
Jews in the material well-being of the individual, that of the Greeks in the force and grandeur of the man, and that of the Romans in the might and glory of the State; simply because such were the various forms the egoism of the proprietary classes assumed among these different nations. It is the interests of this class which in reality inspire the necessary moral sanctions, and dictate the lines of conduct to be followed by proprietors and labourers respectively. It is true, the capitalistic character of morality is not at first sight apparent, because it is hidden behind the mask of such high-sounding terms as social welfare and collective utility, with which mankind has always been so willingly deceived. But the slightest examination is sufficient to demonstrate that these turgid expressions are but an impudent falsification of the facts, designed to strengthen the power of the dominant classes, by causing to appear spontaneous and generally useful the very acts these classes impose on others, in order to assure their own well-being - an easy way, indeed, of rendering the subjugated classes more docile! 1

The more clear-sighted thinkers of the world have marked the existing conformity between capitalistic morality and the exclusive egoism of the proprietary classes, and noted the existence of the twofold moral code, allowing pleasure and license to the rich, and counselling submission and obedience to the workers. Many indeed have remarked the aristocratic character of morality, and some have courageously denounced it. The reader doubtless recollects Thrasymachus in Plato's Republic, who insisted that justice was the interest of the stronger; ${ }^{2}$ and likewise John Stuart Mill, who said so explicitly: "Wherever there is an ascendent class, a large portion of the morality of the country emanates from its class interests and its feelings of class superiority. The morality between Spartans and Helots, between planters and negroes, between princes and subjects, between nobles and roturiers, between men and women, has been for the most part the creation of

${ }^{1}$ Conigliani, in the Giomale degli Economisti, August, 1592.

${ }^{2}$ De Republica, i., 9. 
these class interests and feelings." 1 And elsewhere the same writer says: "In an aristocratic society, the elevated class, though small in number, sets the fashion in opinion and feeling; even virtue will, in that state of society, seem to be most strongly recommended by arguments addressing themselves to pride; in a democracy, by those which address themselves to self-interest". ${ }^{2}$ But the writer who has put this concept in its truest light is undoubtedly Mandeville; and it is precisely because he openly expressed a truth that subsidised science had tried in a thousand ways to hide, that his Fuble of the Bees has been condemned. According to Mandeville, public benefits are promoted by private vices, that is to say, by the exercise of the most unbridled egoism; not, however, on the part of all men, but simply on the part of those directing society. For these ruling classes, this philosopher-physician, accordingly recommended a morality of limitless license, while he, at the same time, reserved a Christian morality of toil and submission for the poorer classes. ${ }^{3}$ Albert Lange rightly observes, that Mandeville's ethics were designed expressly for modern capitalists and founders of joint stock companies, ${ }^{4}$ and it is a significant fact that the doctrine was proclaimed and welcomed at the very epoch when nascent capital required free scope for its spoliation, and an extremely elastic system of morality. But this idea that public benefits are promoted by private vices has a still deeper significance, which it will be well to take account of at this point. Capitalistic property possesses, in fact, an historical justification, since, at a certain period of social evolution, it is the condition precedent to the association of labour, and, consequently, to civilisation itself. Inasmuch, then, as capitalistic property can only be developed

'John Stuart Mill, On Libcrty, London, 1868, p. 15 . Lange, loc. cit., ch. ii., p. 462.

${ }^{2}$ John Stuart Mlili, Dissertations and Discussions. Democracy in America Henry Holt \& Co., 1882, vol. ii., p. 129.

${ }^{3}$ Mandeville, The Fable of the Becs, Ed. Edinburgh, 1772, pp. 120-140.

-Lange, loc. cit., pp. 421, 309, and Adam Smith, loc. cit., p. 273. See also Hasbach's " Essay on Mandeville" in the Fahrluch fiur Gesctagebung, 1890 , pp. 34.40. 
through the unrestrained egoism of the privileged classes, the morality which is thus inspired, and which both encourages and sanctions this state of things, does more than merely cater to the sordid interests of the proprietary classes. In a broader sense, these ethics are the theoretical expression of the supreme interests of civilisation, of which capitalistic egoism is but the blind tool.

Such is the essential contradiction between the free morals of individual egoism prevailing in the final economy, and the coercive morality of disciplined and perverted egoism that we find in the capitalistic economy. The difference in method by which such moral coercion has been applied during the successive stages of capitalistic appropriation has also exerted important influences that deserve to be mentioned. The more violent the suppression of the free land, and the greater the moral coercion exerted upon the poorer classes, the narrower is the sphere of action within which they are allowed to move. Now it is easy to understand that the more limited the sphere of action conceded to a certain class, the more readily will the members of this class endeavour to break through the barriers wherewith one would encompass their liberty, and the more frequent, in consequence, will be their lesions of the laws that oppress them. The immoral acts committed by the poorer classes are accordingly more numerous in proportion as the force restraining them is more rigorously applied, and become less and less frequent as continually milder methods are resorted to in the suppression of the free land. For the same reason, one might be led to conclude a priori that the immoral acts committed by the proprietary classes tended, on the contrary, to increase, inasmuch as economic progress leads to greater restrictions in the proprietors' sphere of action against labourers and competing proprietors. But this is only the case to a limited extent. True, in proportion as the means employed in suppressing the free land assume a less violent character, so much the less possible does it become for capitalists to perpetrate deeds of violence against the labourer; and all acts of this kind, furthermore, meet with a sudden check just so soon as the legal liberty of the labourer becomes an 
essential condition of efficient production. But the very economic progress which thus gradually precludes the possibility of violence on the part of capital against labour, at the same time eliminates the patriarchal relations that accompanied the earlier economic systems. Thus the kind and almost paternal feelings that actuated the proprietor of the middle ages in his dealings with his serfs, urging him to ameliorate their lot with his attentive care, were sentiments that belonged exclusively to the organic conditions of the serf economy, where the wellbeing of the labourer constituted a necessary condition of capitalistic production. But with the institution of the wage economy and the prevalence of technical capital all such sentiments had necessarily to disappear, for there is no longer any connection between the welfare of the labourer and the quantity of the product. Hence the modern capitalist's cruelty toward the wage-earner who is pitilessly bound to protracted toil that is alway's exhausting and often unhealthful, forms a painful contrast with the sentiments of kindness that bound the medixval proprietor to his serf.

It is only when capitalistic exploitation has stretched the wage-earners' endurance to the utmost, and when the continued exhaustion of their forces threatens to check production at its very sources, that the inherent necessity of maintaining the capitalistic system imposes a check upon this homicidal exploitation. Evolied once more by the organic conditions of the economy, there then appears a new speeies of charity, no longer individual as heretofore, but collective in character, and imposed by the law of the state. ${ }^{1}$ Hence originate all the provisions the State feels called upon to make for the protection of women, children and impotents, for the limitation of the hours of labour and the like, all of which go to make up what we call social legislation. Now the mere necessity of enforcing by law the fulfilment of deeds that were formerly

1 The metamorphosis rendered necessary in morality by a change in the underlying economic conditions has heen well grasped hy Jeüro Ono

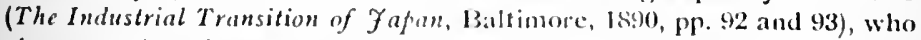
observes that Japan's late transition from the feudal to the wageeconomy is also making a moral transition necessary. 
dictated by the individual conscience of the capitalist, shows of itself that the morality of the proprietary class has, in some respects at least, undergone a retrogression, inasmuch as it now permits actions injurious to others that in former times it forbade. It demonstrates also that, while the labourer's liberty has increased with economic progress, that of the capitalist in his relations with the labourers has not correspondingly diminished, but simply assumed a different form. Capital now stops short of violence, because this, in our day, is incompatible with the capitalist's own interest, but it reaches out correspondingly on the other side toward usurpations and excesses, which, though formerly injurious to the agent, nowa-days redound to his advantage. As much might be said concerning the relations that exist among the proprietors themselves, whose excesses are more or less restrained by moral limitations, according as they cause any appreciable prejudice to the dominant economic system.

Thus we see that public opinion in the United States indulgently puts up with malversation in office, the abuse of employees, and the sale of votes, while in Europe such things arouse the utmost indignation. And why? it will be asked. Because, on account of the limitless resources of this fortunate land, excesses of this kind cause no prejudice to the capitalistic classes, and even accord them positive advantages by absorbing the plethora of riches which, otherwise, might endanger the persistence of their income by raising the wages of labour. In Europe, on the other hand, such a procedure would inflict real injury upon the capitalistic classes by diminishing and jeopardising their acquired fortunes.

The sphere of action allowed to the capitalist in his relations with the labourers and with other capitalists is thus always the unconscious product of organic, economic conditions-or, in other words, of the real interest of the proprietors, which in turn allows a greater or a less freedom to the acts and usurpations of the capitalist class. , 


\section{CHAPTER IV.}

\section{MORAL CRISES.}

As the reigning morality is always the product of existing economic conditions, the disintegration of any established economic system necessarily involves the dissolution of its corresponding system of cthics. The process of economic decomposition itself effects this moral dissolution, by cutting off the support that the unproductive labourers have, up to this, accorded-or rather sold-to capital, and causing them eventually to join forces with the productive labourers. We have already seen that in order to exert moral suasion sufficient to pervert the egoism of the oppressed classes, the co-operation of unproductive labourers is required, whose special mission it is to reconcile the groaning masses with the capitalistic system. Now the decomposition of an established system of capitalistic economy carries with it a progressive diminution in the income from property, and consequently involves a corresponding falling-off in the unproductive labourer's share therein. This in turn dissolves their partnership with capital, and puts an end to their task of psychologically coercing the productive labourers. The bandage is thus suddenly removed from the eyes of the oppressed, and the systematic perversion of human egoism up to this, in force, is abruptly brought to an end. The labourer sees at last the line of conduct that is dictated by his real egoism, and recognises that the destruction of the existing social order can alone ameliorate his condition and assure him his liberty.

But this clear perception of social realities on the part of the labouring classes, this crystalline clarity in the relations existing between the individual and the economic system, hardly endures for the space of a morning. Scarcely has the inevitable course of events, embittered now hy the rcbellious acts of the labourers, 
hounded to its grave the existing system of oppression, when there arises another, which is milder in character, upon the ruins of that which has disappeared. Under the new system of suppression, the ancient alliance between capital and unproductive labour is re-established, and at once inaugurates a new process, which is better adapted to pervert the egoism of the productive labourers.

The great crises that morality has passed through in history during periods of social decomposition and recomposition set forth this interesting process with marvellous clearness. Upon the decline of the Roman economy, for example, production, carried on with slave labour, became evermore inadequate, and finally ceased to afford an income to capital. Then the clients, who from the first had allied themselves with the owning classes in order to share in their profits, refused any longer to lend them their support, being henceforth too miserably paid, and passed over with bag and baggage to join the ranks of the labourers. These same allies, who had up to this taken such pains to blind the slaves to the course of conduct that was really in conformity with their interests, now enlightened them in this regard, and provoked them to revolt. Under the influence of this new alliance between unproductive labourers and rebellious slaves, the morality of subjection was suddenly transformed into the ethics of revindication which found adequate expression in the socialistic words of Jesus. Clients and slaves were readily converted to the new creed; but the patricians, the rich proprietors and the educated classes generally remained true to paganism. But after the revolt of the slaves had hastened the inevitable dissolution of the Roman economy, a new form of capitalistic property was developed, and with it a fresh alliance between capital and unproductive labourers, who were now employed anew in coercing the enserfed classes. What the Roman clients accomplished by fear, the priests of the feudal age effected with the aid of religion, whereby they succeeded in so perverting the egoism of the labourers as to keep them from revolt. It is curious to note how such perversion was deduced, by means of a simple dialectic artifice, from the very morals that had previously 
inspired the demands of the rebellious slaves. Despite the fact that the greatest of all reformers denounced the furtive nature of property and the usurpatory character of wealth, both of which he excluded from the future life, ${ }^{1}$ his disciples hastened to draw a conservative deduction from this same doctrine. The inevitable exclusion of the rich from the kingdom of heaven, and the necessary triumph of the poor in the life to come, constituted, indeed, an excellent argument to reconcile the oppressed with the social system under which they groaned. Thus, under the evil influence of property, the very morality which for the moment enlightened the labourers on their true course, became an efficient means of perverting their egoism, and turning it from its proper path. Just as the Bible, in spite of its republican spirit, had so often been used in the defence of kings, so now the Gospels, despite theil communistic tone, likewise became a powerful instrument for the protection of the richer classes when confided to the hands of mitred sophists, who understood how to transform the greatest book of socialism into the meanest defence of property.

The inherent antithesis between the primitive and essentially revolutionary nature of Christian morals, and the quietive character derived therefrom through a malicious artifice, necessarily engendered pernicious digressions during the course of religious evolution and introduced violent contradictions which often ended in bloody conflict." But these contentions and

"The essentially critical and socialistic character" of the carly Christianity has been very clearly set forth by Nitti in his Socialismo cattolico, 2nd cd., Turin, 1891.

${ }^{2}$ Thus, for example, in 1322 a Provençal priest, who was a very warn advocate of the primitive Christianity, declared that as Christ had owned nothing, so the Church should likewise own nothing. This audacious assertion which jeopardised the very integrity of ecelesiastical revenues called furth an encrgetic reaction on the part of prelates and monks who hastened to combat the thesis. Even the sovereign lontilf did not hesitate 10 condemn this opinion bostile 10 Christ's property, as, if sanctioned, it would have caused the Roman Church, itself so richly endowed with earthly goods, to be considered heretical. The minor friars continued nevertheless to maintain the assition, and by way of punishment they were put under an interdiction by the l'ope from crer possessing any thing (Villani, Chroniche. Filorence, 1s23, iv., p. 1t5). 
antinomies concern us but little. All we have in mind is to affirm the interesting dualism that is to be observed in every period of moral crisis. In the earlier phases of such a crisis, morality guides the labourers in accordance with their interests, but during the later phases it reverts again to a systematic perversion of their egoism. And this is not a phenomenon peculiar to the great period of history we have just cited. At the moment when the feudal economy was about to disintegrate, we notice again the rapid development of a revolutionary morality which enlightened the egoism of the serfs and organised them for a Titanic assault upon property. But shortly afterwards, morality again assumed its old form, and by systematically perverting the egoism of the suffering masses, it still holds them within the orbit of their duty. And what used to be the worl of priests has since become the office of publicists, professors, lawyers and magistrates.

Thus all moral revolutions following the same course pass through two phases which correspond to the double process of social decomposition and social recomposition. The former, which is essentially subversive, enlightens the real egoism of the oppressed, and urges them to consummate the downfall of the already tottering edifice; while the latter, which is essentially conservative, applies itself to welding the chains of the fresh victims of the rising social form.

Such are the effects which economic revolutions exert upon the morals of the labouring classes; but economic decomposition and recomposition exercise diametrically opposite influences upon the morality of the proprietary class. At the moment when the disintegration of capitalistic relations is about to direct the egoism of the poorer classes toward its real ends, it begins at the same time to undermine the egoism of the proprietary class by removing bit by bit its foundation rests. In fact, the essential characteristic of such periods of economic decomposition consists in the impotency of capitalistic selfseeking, which, while still aiming at enrichment, is driven by the stress of circumstances in an opposite direction. The evident futility of an egoism which reacts upon its own designs necessarily engenders a kind of moral indifference and a disdain 
for pleasure and pain, which are precisely the characteristic signs of these great periods of social decomposition. Thus, during the grand crisis of the Roman economy, we mark the appearance and ascendency of Stoic morality, which constituted the exact reflex, as well as the highest idealisation, of an egoism which no longer attained its ends. ${ }^{1}$ In like manner, during the crisis of feudal society, a morality of indifference again appeared and flourished in England in the sects of the Quakers and Puritans, and in Germany among the Moravians and Hussites. Out of this again usually proceeds the asceticism of critical periods, which, on the one hand, inspires the demands of the subjugated classes by creating a spirit of sacrifice, and arousing that cult of the ideal which alone renders great revolutions possible; and, on the other hand, corresponds to the disillusion of the capitalists, who are no longer able to obtain normal satisfaction from their egoistic demands. It is hardly necessary to add that these periods of discouragement for capital are but transitory, and that they cease with the passing by of the impotency that momentarily paralysed capitalistic egoism and interrupted its efficiency. As soon as the real egoism of the labourers begins to decline under the influence of methods designed to pervert it, capitalistic egoism rises again and starts on a new and more vigorous flight. Then the morals of capitalistic egoism again hold swaly, but they in turn must now he restrained by a new moral force, in order that they may not go so far as to compromise the very existence of property.

Running parallel to this revolution in the morals of the dominant class, a like change is effected in their manner of looking upon life, in their conduct, and consequently in the tout ensemble of scientific and literary production which proceeds solely from this class. It is, therefore, not surprising that every great economic revolution has been followed by a literary revolution which forms, as it were, its complement and necessary consequence.

Lecky (loc. cit., i., pp. 239, 338) very properly remarlis that the transition from Roman materialism to Stoicism and Christian asceticism, was the product of the underlying social transformation. See also Lange, loc, cit., i., p. 147. 
Philologians have long since made note of the fact that economic transformations are the cause of great changes in language. The classic speech of normal periods is nothing but the language spoken by the dominant classes. It alone possesses a literature of its own, and it alone is woven into the exquisite productions of science and art. The speech of the lower classes, on the contrary, is condemned to occupy an inferior position. It forms no part of any literary production. It is but a dialect, and constitutes a kind of unobserved undercurrent in the great river of language. But during periods of social decomposition, when the oppressed classes assume the ascendency and succeed in establishing their claims, their dialects triumph likewise. These dialects then take the place of the classic language up to this in vogue, or at least limit its absolute sway, and compel it to incorporate a large number of its dialect forms and accord them the right of citation. A complete transformation is thus effected, and the language becomes substantially modified by the new elements that social evolution has thus forcibly added. ${ }^{1}$

And side by side with this revolution in language, a like revolution is effected in literature which also docilely follows the changes occurring in the social system. Thus the poesy of the Trouvères and Troubadours, which flourished so rarely during the feudal epoch, and was itself a product of the economic and family conditions prevailing during the middle ages, faded away with the appearance of the bourgeoisie in history. Sismondi tells us that in 1324 the people of Toulouse conceived the idea of inaugurating a competition in Provençal poesy, to honour the entry of Charles IV. into their town. Seven bourgeois of Toulouse, who called themselves les sept troubadours de Toulouse, invited poets to present their works, promising as a prize to the victor a golden violet and the title of docteur dans la gaie science. Such was the origin of the floral fêtes, by means of which they hoped to retain at least the shadow of the ancient Provençal poesy. But the times were changed, and with the disappearance of the courts of the South, had also

${ }^{1}$ Cf. Max Müller, Lectures on the Science of Language, 1866, i., p. 197, and Whitney, The Life of Languige, 1875, p. 103, 
gone the Troubadours and the customs and manners of life that were peculiar to them. The bourgeois of the towns who replaced them were of far greater worth perhaps, but they were certainly much less poetic. They were less addicted to idleness, in short, and they possessed less imagination, less fondness for pleasure and less gallantry. ${ }^{1}$ A literary revolution, different indeed from the above, but nevertheless proceeding from the same series of causes, was also effected in Italy by the bourgeois revolution. Thus the civil revolution of 1282 was succeeded in Italy, and more particularly in Tuscany, by a revolution in literature as well. And again, the Tumult of the Ciompi, and the democratic-bourgeois revolution were both followed by a corresponding form of literature which poured itself out in invectives against poverty and against the species of Christian socialism advocated by ascetic writers. In like manner the amorous and erotic poetry of the eighteenth century expressed the passing-over of the bourgeois class to the life of pleasure that had up to this remained an exclusive privilege of the nobility. The great revolutionists in France, Robespierre and Saint Just, for example, wrote amorous and erotic poems ; 2 and in Italy also, Parini's poetry was but the literary expression of the bourgeois' revolt against the nobility. Across the Alps this same revolt found equally good expression in Beaumarchais, whose Mariuge de Firaro effected a revolution in French comedy. $U_{p}$ to this one had been in the habit of seeing the nobles make sport of the people on the stage, but now for the first time a very different performance was presented. Lessing, one of the greatest, if not the greatest of Germany's authors, both in his critical and asthetic works, energetically espoused the interests of the bourgeois class, whose wealth and power were then beginning to assume an increasing importance.

At every involution of the social organisn, we note, on the contrary, a corresponding reversion in all forms of literature. And by way of a memorable example, we have only to point to the bestial degeneracy of English literature during the period of the Restoration.

'Sismondi, loc, cil,, ix., p. 419. "Carducci, Libro dellc Prefazioni, 
Thus in all countries and at widely separated periods, economic crises have always inevitably resulted in corresponding moral crises. Now if our present economic system is bound to go to pieces in the not far distant future, it is certainly not rash to forecast the approach of a moral decomposition which will in turn be followed by a period of moral recomposition. The unproductive labourers now allied to capital and employed in perverting the real egoism of the wage-earners by systematically influencing public opinion, will break away from this alliance as soon as the capitalistic income begins to fall off, and pass over to the ranks of the labourers to lend them their aid and advice. No longer artificially perverted, the labourers' egoism will then be developed directly to their own advantage, and this will impel them to overthrow the social order that oppresses them, in order to replace it with a better economic system. And this must be the one social form which is superior to the present in productive power, namely: the mixed association. Then as the product of this economic transformation, a moral crisis will occur whence will finally issue the ethics of the new era. Being no longer imperative in character, and requiring neither moral suasion nor a perversion of egoism, the morals of the future will thus be spontancous and dictated by enlightened self-interest. A moral system of this kind, freely and voluntarily adopted by individuals who are equal copartners, will of itself suffice to assure union and reciprocal respect, social equilibrium and the happiness of mankind. 


\section{CHAPTER V.}

A CRITIQUE OF THE DOMINANT THEORIES OF MORALITY.

Since the human mind began to concern itself with the problems of morality - which, indeed, are as old as philosophy itselftwo concepts have battled for supremacy upon this field of thought. On the one side is ranged the theory that deduces morality from precepts of supreme justice, either conceived by man himself, or revealed to him through some Divine agency; while, on the other side, the opposite theory prevails, which considers human happiness the sole criterion of moral acts. According to the former theory, moral actions should be essentially altruistic, that is to say, they cannot be actuated by any personal interest of the agent himself. Following the latter theory, on the contrary the hidden spring that determines morality and the scries of acts it counsels or commands, is to be found in the well-ordered interests of the individual and of society. It is only through an analysis of the economic bases of morality that we can detect the organic flaw in each of the above doctrines, and at the same time recognise the particular phases of the truth represented by each, which explain their temporary success at different stages of civilisation.

The theory which conceives of morality as the sublimate of individual egoism and regards the pursuit of individual happiness as the highest criterion of ethics, collapses at once uncler the most elementary analysis of the capitalistic economy. Under such a social system, the class that is numerically the stronger clearly acts contrary to its own interests in submitting to the usurpation of which it is the victim, and it is only by silencing the egoism of this class that capitalistic forms are able to exist at all. It is, indeed, so far from the truth that in this economic system moral acts are dictated to individuals by their real 
interests, that if every one were really to follow his egoistic instincts, the entire social structure would immediately collapse like a house of cards. ${ }^{1}$ However inadmissible as a whole, this doctrine nevertheless contains a modicum of the truth. What though our imperfect moral systems be not grounded upon individual egoism, they are nevertheless always rooted in the egoism of the capitalistic class; and what though the conduct of the poorer classes be in reality contrary to their actual interest, their acts nevertheless conform to an apparent egoism that is held before them artificially by means of a clever display of psychological force.

A like judgment must be passed upon the opposing theory which makes disinterestedness the dominant characteristic of the moral acts that God imposes upon His creatures as their inviolable duty. If applied to the labouring classes this theory has an incontestable appearance of truth, and it was no doubt evolved from actual experience with the conduct of the lower classes. It is perfectly true that the class deprived of its liberty of choice adheres to a line of conduct that is in fact, at least, altruistic, and which seems therefore inexplicable under any theory of egoism. It is equally clear if we except the period of slavery that such altruistic conduct has always been assured by means of a line of ascetic, religious and moral precepts that preach disinterestedness and meekness to the groaning multitude, and this in itself is sufficient to have engendered the concept of an abstract moral law revealed to man and imposed upon humanity as a duty regardless of the precepts of individual egoism and even contrary to the same; contrary that is, to the happiness that human egoism naturally sceks. But the plausible look of this conclusion does not succeed in hiding its inherent flaw, for even so cursory an examination will at once reveal the fact that the conduct of the poorer classes, although altruistic in deed, is, nevertheless directly and exclusively inspired by individual egoism. These acts are indeed altruistic in so far as their ultimate consequences are concerned, since they redound to the advantage of the capitalistic class and to

${ }^{1}$ Hertzka lias some excellent observations to offer on this point (Die Gesetze dor socialen Entwicklung, Leipzig, 1886, p. 274). 


\section{A Critique of the Dominant Theories of Morality. 61}

the disadvantage of the poorer classes. They are nevertheless immediately 'egoistic, inasmuch as the labouring people have their own good in mind and are really seeking their own advantage. This class may indeed be mistaken in its calculations in that it prefers to forego present advantages in order to secure fanciful rewards or avoid imaginary ills in the future; but this does not prevent egoism from being the mainspring of their acts; nor does it preclude the possibility of ascetic morality and the ethics of submission and obedience being themselves rooted in the self-interest of the individual which may, indeed, be skilfully perverted but which is never entirely suppressed.

There is also an intermediary doctrine which deserves special mention because it is so generally followed. Morality, according to this theory, is the product of the egoism of the human sfecies, or, as others express it, the product of our altruistic instinets. These are at botton egoistic instincts, but they find their satisfaction, nevertheless, in the performance of just and benevolent acts. Thus, according to some writers, moral acts either result from the mere pleasure afforded by doing good, or emanate from that feeling of pity which vibrates in the hearts of most men, and urges them with an irresistible force to the performance of disinterested acts. ${ }^{1}$

But first we might ask these theorists whether the altruistic instincts upon which they rely actually exist, and whether, as a matter of fact, they do influence human conduct. And with still greater assurance we might request the doctrinaires of sympathy to tell us frankly if man were free to act as he would, and if the opposition of others in no wise restrained him, whether he would not kill his fellows simply " pour frotter ses bottes avec leur graisse "."2 We might, indeed, go so far as to say that this desire of explaining benevolent acts as products of an instinct, is an casy way of avoiding deep research into the causes of acts and feelings, and we might also suggest that

${ }^{1}$ Schopenhauer, loc. cit., pp. 118, 255. Ardigò has enunciated an idea that does nol differ much from this (La morale dei positizisti, Milan, 1879, p. $166 \mathrm{ff}$.$) .$

'Schopenhauer, loc. cit., p. 107. 
the process of reasoning through which these theorists have endeavoured to afford a logical, metaphysical or positive basis for these instincts is extremely arbitrary. ${ }^{1}$ Or we might add with Spencer that sympathy becomes weaker as misfortunes increase, and that pity is less easily moved and less intense just when it should wax strong.

But an argument whose logical force runs along quite different lines may better be directed against the doctrine in question. If, as a matter of fact, pity and the satisfaction of doing good really constitute the mainspring of human acts, then the social schism that is characteristic of the capitalistic economy would carry with it no sinister results. Nor would it involve usurpation, since the privileged classes if inspired with such altruistic sentiments would naturally endeavour to eliminate all chance of injury to the poorer classes resulting from their inferior condition, and themselves abstain from the commission of all violent and illegitimate acts. It is scarcely necessary to add that nothing of the sort has taken place; but that, on the contrary, in the relations between capitalists and labourers free rein is given to exploitation and the most unprincipled spoliation. We are therefore forced to recognise that altruistic sentiments play no part in the more normal and really important relations among men; but that on the contrary, absolute egoism there reigns supreme. If pity really affects human actions, its influence must therefore only be subsidiary, and exerted with a view toward mitigating and making partial amends for the wrongs done by the egoistic acts of man.

According to this view, egoism would supply the motive for the habitual and more important acts of life and thus constitute the mainspring of morality, while altruism would merely form the motive of a secondary ethical code serving to blunt the too sharp and painful edges of egoistic morals. Men would act, in short-to follow a comparison made by Lange-like the English dealers in Indian idols, who in their capacity of merchants favour Buddhism, but as Christians give alms to Protestant

${ }^{1}$ See for example Schopenhauer, loc. cit., p. 178 ff. Ardigò, loc, cit., p. 154 ff. 
churches and encourage their missionary work. That is to say, the individual in his capitalistic capacity might practise the most shameless extortion against his fellows, while as a compassionate being he loaded his own victims with kindness. But the co-existence of two such contradictory systems of morality must appear upon a moment's reflection to be the acme of absurdity. What importance are we to attach to sympathy of this kind, and how can we possibly regard it as an autonomous moral factor or take it as a guide to conduct when it does not succeed in directing us in the more serious and important affairs of life, but lcaves us still under the sway of our egoism? But the moment we recognise the fact, and there is, indeed, no help for it - that pity is after all but a subsidiary moral factor acting within the limited sphere allowed it by our dominant egoism - the way is already opencd to a more synthetic, harmonious and truer conception, according to which egoism determines not merely the essential but also the subsidiary moral code, and is only masked behind the altruistic sentiments which appear to dominate the latter. Sympathy is but the outward and visible mantle, while the unseen hand operating under this cloak is none other than cgoism itself. ${ }^{1}$ it is the voice of egoism that advises the dominant class to relieve the sufferings it has caused, in order to avoid the danger of possible retaliation. To be sure, egoism of this character is far too remote to be directly appreciated by the beings it inspires. Their conscience merely perceives a mirage which causes their acts to appear like spontaneous outbursts of pity and love-for certainly no one would think of saying that he who succours the poor and un fortunate, does so with the premeditated intention of avoiding possible reactions on the part of the down-trodden classes. But it is none the less true that the alleviation of misfortune is in the interest of the very classes that have unconsciously caused

'Spinoza said: "L'homme aide ses semblables uniquement parce que sa raison le lui conseille; en dehors de celle ci, il n'y a plus qu'une passion blâmable, la pitić" (Ethique', part. iv., Propos. 50). And a philosopher who certainly cannot be atcersed of materialistic excesses concludes by affirming that sympathy toward others is nowhing but sympathy toward ourselves (L'womo e le scima morali, Milano, 1869, p. 29). 
it, and it is this very interest that constitutes the unrecognised impulse of their benevolent acts. ${ }^{1}$

These general and abstract theories of morality are, consequently, all three incomplete. First, the egoistic theory does not explain why the more numerous classes of society act according to criteria that are opposed to their real egoism. Secondly, the theory of duty fails to take account of the fact that the ethics of every epoch are inspired in the interests of the proprietary classes, and that the labouring classes are influenced in their actions by an apparent egoism that is artificially engendered in their minds through moral suasion. The third theory finally becomes involved in an absurd category of altruistic sentiments, and seems to ignore the egoistic elements that lie at their root.

John Stuart Mill and Herbert Spencer have given us truer and much more complete theories of ethics. According to Mill, utilitarian morals can only be maintained when social laws and regulations have placed the happiness of every individual in harmony with the interests of the whole. In a society of masters and slaves, on the contrary, the idea of the utility of acting in another's behalf could never arise. And in general it may be said that whenever a social institution allows one class to promote its interests at the expense of another, this

${ }^{1}$ Wake remarks that the Arab's generosity is simply the result of his enlightened self-interest; for he knows full well that the possession of wealth does not count for much in the midst of the desert. It is the poor but strong man who is apt to rule there, and it is therefore advisable to secure his good will (loc. cit., i., p. 475). The distribution of corn in ancient Rome, says the same author, was no act of charity but simply a matter of policy (loc. cit., i., p. 461). One could say the same of the English poor laws, of the Toynbee Halls, of the missions organised by General Booth, and the like. "Capitalistic charity," says an official reporter, "does not spring from sympathy but from the presence of a common danger" (Fifth Annual Report of the Statistics of Labour, New York, 1887, p. 19). A German writer expresses himself still more bluntly as follows: "The eleemosynary institutions founded by capitalists are rarely inspired by charity. Often the interest on the capital thus invested falls short of the amount they would have been obliged to expend in providing for the needs of the poor" (Singer, Soziale Zustände in Böhmen, Leipzig, 1885, p. 102). 
institution will appear both just and moral to the privileged class, simply because it is useful to it. Under such conditions, therefore, the egoistic sentiment would never succeed in establishing perfect moral relations. But inasmuch as our capitalistic system allows one set of men to follow their interests at the expense of another, this amounts to saying that utilitarian morals are inconceivable in a capitalistic society, and that they can only be finally instituted in some higher social form. And this, moreover, is precisely what our eminent philosopher himself explicitly affirms when he concludes that the usefulness to the individual of respect and kindness toward others-that is to say, the acceptance of utility as the foundation of perfect morality-can only be realised in a society of equals. ${ }^{2}$ What we have thus far maintained, substantially accords with these ideas, as can readily be seen. Where Mill makes his only mistake, it seems to us, is in believing that intellectual progress will of itself bring us to an epoch when utilitarian morals may be established, ${ }^{2}$ and that the institution of this higher social system rendering perfect morality possible, can be entrusted to laws and social regulations. In reality, however, this metamorphosis of our existing capitalistic system into a social constitution founded upon eyuality and co-operation can only be accomplished through the natural evolution of economic relations.

Of Spencer's well-known doctrine we have also something to say. According to his theory we have first to conceive of an ideal morality based upon the final utility of individual acts, which will assure the survival of the fittest and !ead to perfect social happiness. But this moral system is only to be realised after a long evolution of the human mind, and as the last stage in a series of temporal experiments with the influences exerted by human actions in producing happiness. During this evolutional period, the moral conduct necessary to guarantee social cohesion can only be assured by means of moral, political and social regulations." This concept has the great merit of recog-

1 John Stuart Mill, Utilitarianism. ${ }^{2}$ Id., loc. cit.

${ }^{3}$ Spencer, Les bases de la morale evolutionniste, 1'aris, 1879, p. 126 ff Sce also Gabelli, loc. cit., pp. 104-106. 
nising that morality, like all other manifestations of human activity, is passing through an evolution and tending toward a final form. It is defective, however, in several important points that must be taken into account.

In the first place, Spencer affirms the existence of a final morality without accurately determining the social conditions essential to the realisation of this ethical ideal. He regards the imperfect morals of war as belonging to the period of militarism, and believes that they will fall into decay with the growth of the spirit of industrialism that is beginning to show itself among the civilised nations of the world. But this distinction between the military society and the industrial society does not go to the root of the matter. It opposes against each other two organisations that are both based upon a compulsory association of labour, and which do not differ from one another materially, and least of all in their moral systems. In the industrial society also it is the ethics of animosity that prevail, and within our most cultured communities a certain portion of the population is given over to the most unbridled egoism, while the remainder is held in check through a systematic perversion of its egoism rather than by any sentiments of respect.

We must take still more serious exception to Spencer, when he declares that the ethics of egoism-that is to say, the final morality-will assure the survival of the fittest, and therefore constitute a factor in progress. We cannot accept this conclusion. In the pure cconomic form, where alone the philosophy of egoism could prevail, the strong would find no means of exerting their strength at the expense of the weak. They might make it serve, indeed, to increase their own product, but beyond this legitimate reward, which far from being injurious to the community, would rather be a benefit, they could procure no other advantage at the expense of the weaker members of society. The very idea of the survival of the strong through a victory won over the weak, must, consequently, be regarded as an unconscious and inexact reminiscence of experiences encountered in the capitalistic society, and inapplicable, therefore, to the social phenomena 
belonging to economic equality. We say that the reminiscence is inexact, because in the triumph of one class of men over another in the capitalistic society, the victors are by no means the stronger. Were they so, they would not have to resort to the complicated methods we have already analysed in order to pervert the egoism of the vanquished and so guard against possible reactions on their part, for their superior strength would itsclf suffice for this purpose. ${ }^{1}$

There is yet another point in the theory of this great philosopher from which we must mark our dissent. Spencer belicves that the gradual transition from compulsory morality to the spontaneous ethics of egoism is duc exclusively to the growth of experience. The morals that rest upon political, religious and social sanctions belong, he thinks, to an early stage of development when the human race was not yet sufficiently informed by experience as to the efficacy of acts that go to produce social happiness, and had, consequently, to be compelled to do those things which were useful and leave undone those things which were injurious. But here Spencer fails to see that in a community where men are free to co-operate on equal terms, where economic relations are consequently transparent, and where no social institutions exist to warp individual judgment, a very limited degree of experience suffices to demonstrate what acts redound to the advantage of the agent. So true is this, that in primitive communities where capitalistic property does not exist, we find that the ethics of egoism succeed perfectly in assuring the welfare of both the individual and society, despite the still embryonic state of utilitarian expericnce. In the capitalistic society, on the contrary, the complexity of economic relations renders it impossible for the owning classes to foresee the results of their own acts, and prevents them consecuently from entrusting themselves entirely to the sway of their own egoism. The labouring classes would, however, readily discover the line of conduct conducive to their welfare were their egoism not purposely perverted. It is thus by no

'This is precisely what Turate has set forth so well in his reply to Cimhalis' work, Il diritto del fill furte, Rome, 1891 (Critica sociale, September, 1891.) 
means due to an insufficient development of the intellect that individuals are now-a-days unable to foresee what acts are in real conformity with their egoism. It is the complication of capitalistic relations that prevents proprietors, on the one hand, be they ever so intelligent, from perceiving the final results of their acts; and the systematic perversion of the egoism of the masses that, on the other hand, prevents the labourers from recognising the results of the acts that are really in conformity with their interests. This impossibility of recognising what acts are in harmony with one's egoism is not, therefore, the result of psychological causes, but due simply to the prevailing capitalistic conditions, which interpose themselves between the intellect of man and the results of his acts, rendering egoism blind and thus incapable of regulating human conduct. The necessary acts have, therefore, to be instigated by moral suasion.

So long as present social conditions persist, even the most marked progress in human intelligence can never clear the way for the institution of the ethics of egoism, because the system would still be vitiated and interrupted in its proper workings by existing economic conditions. But with the establishment of an economy of equals, egoistic morality will at once become possible, as the very equality of conditions will tear away the veil which now renders egoism blind. On this account we are not even able to share Spencer's opinion that the ideal morality stands in the same relation to the relative morals of different historical periods as physiology to pathology; for if we regard these uncompleted moral forms as organic products of historically necessary economic conditions, it is certainly illogical to affirm that imperfect morality is a pathological phenomenon. Rather is it a physiological phenomenon, even as the social organism of which it is the product is physiological in character.

We must therefore conclude that capitalistic morality is made up of a series of regulations, imposed by the owning classes upon the labourers in opposition to their real egoism, and upon their own number in opposition to their immediate interests; and that it is these regulations which succeed in 
guaranteeing the persistence of capitalistic society. But it will readily be recognised, that, though simple moral suasion suffices to hold a certain portion of the population from proscribed acts, there will always remain a certain number who will continue to be rebellious under such slight restraint. Against this element it is necessary to proceed in a different and much more energetic way. In such cases penalties that are substantial and no longer merely imaginary have to be imposed upon the commission of acts threatening the persistence of property. Thus where morality is unable to hold human conduct within the orbit traced out hy the necessities of capitalistic cohesion, a stronger and more definite connective institution-the law-steps in. The law's dependence upon economic conditions will, accordingly, next claim our attention. 

PART II.

THE ECONOMIC FOUNDATIONS OF THE LAIV. 


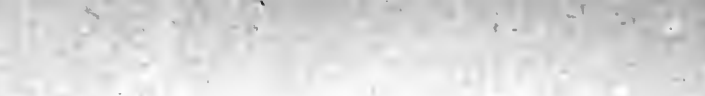




\section{CHAPTER I.}

\section{THE ECONOM 'C BASIS OF LEGAL SANCTIONS,}

When we come to consider the legal characteristics of the final economy, we find the law reduced to a set of imperative rules, designed to protect the different producers in the enjoyment of the results of their labour, and in the accumulation of its products. But, inasmuch as it is to every one's interest in this economy to respect the property of others, the law never has to apply its own penalties, since no one would ever think of violating it. Or if it were ever necessary to resort to legal penalties, it could only be against madmen or fools ; for nothing less than aberration or insanity could possibly impel any one tr? commit illegal acts that clashed with his own interests.

Locke's proposition: where there is no property there is no injustice, is as capable of demonstration as those of Euclid; for the idea of property being a right to something, and the idea we designate under the name of injustice being the invasion or violation of such a right, it is clear that the latter cannot exist without the former. But it is not necessary to go so far as to assume the non-existence of property in order to show the impossibility of injustice; for under an adequate system of private property, any violation of the rights of another would be in contradiction with the self-interest of the transgressor, since, as we have alrcady seen, it would necessarily react to his own disadvantage. No violation of another's property rights could occur in a society made up of producers of capital and ordinary labourers all having equal incomes; for any attempt on the part of one member of the group to usurp the rights of another could only succeed in driving the latter to disrupt the mixed association. This, in turn, would result in lessening the joint productivity of labour, and so diminish the income of the 
would-be usurper. In such a community, the law would therefore simply consist in the theoretical affirmation of the rights and duties of the individual, and these would never have to be incorporated into penal sanctions. Utility, which according to Hobbes constitutes the essence of the law in the state of nature, would then form the sole rule of justice; but, instead of leading to the war of all against all, this criterion would naturally and logically result in the respect of reciprocal rights and in social peace.

The logic of this conclusion comes out with still greater clearness in the argument drawn contrario from the legal characteristics of the economic form radically opposed to the above; namely, the capitalistic economy. It is evident that the law which assures to every individual the peaceful enjoyment of his income is no longer so sure of universal observance in a comnunity that tolerates, sanctions, and even accentuates economic inequality, and where one portion of the population grows rich at the expense of the other; for it is to the interest of tiose who possess less to usurp the rights of those who possess more, and those who labour without receiving any revenue have certainly everything to gain from violating the law and appropriating the revenue of the capitalists and nonlabouring proprietors. And although in the free-land economy violations of the law are powerless to augment the welfare of the agent, and in the end only succeed in diminishing his prosperity, where land is pre-empted, such illegal acts constitute, on the contrary, a very efficacious means of increasing the transgressor's competency. For this reason, the law can no longer confine itself, in this phase of economic evolution, to a mere theoretical affirmation of the economic privileges of the individual, but must arm itself with rigorous penalties to lay upon those whose individual interests urge them to violate its rules.

We have already noted while speaking of morality, that, in the capitalistic society, the reai interrests of the labourers urge them to revolt against the capitalistic class, while the conscious interests of the members of this capitaistic group lead them to resort to reciprocal usurpation among themselves, and to be 
implacable in their attitude toward the labouring population, although such conduct really results to their ultimate disadvantage. For this reason, as we have seen, the ethics of egoism cannot, under such conditions, lead to social equilibrium, and it is, therefore, necessary to resort to an imperative code of morals, with a view to vitiating the egoism of hoth classes by creating an ostensible egoism calculated to detach the poorer classes from their real interests and the well-to-do classes from their conscious interests. In cases where this perversion of egoism is not complete in its results, and where, on this account, the imperative code of morality does not of itself suffice to assure social equilibrium, the law intervenes. Instead of vitiating human egoism, and then allowing the individual to act freely according to the tenets of his perverted interests, the law proceeds either by absolutely forbidding acts that are in confornity with one's own interest, or by subjecting such acts to penalties so severe that their performance becomes henceforth anti-egoistic. Morality thus comes to the support of the capitalistic system by means of a fiction; for, even while permitting the individual to follow out his own inclinations, it takes care to vitiate his egoism and direct it in a sense opposed to his interests, real or conscious as the case may be. The law proceeds more explicitly and imposes at once so severe a penalty upon the egoistic act that its performance really hecomes contrary to the agent's interest. Morality imposes an ostensible penalty upon him who commits an egoistic act and thus renders the abstention therefrom apparently egoistic; while the law, on the contrary, inflicts its effective punishment upon the self-same act and thus renders the abstention really egoistic. Morality accordingly vitiates our interests, while the law, on the other hand, alters the conditions under which they are moved and determined.

This characteristic of the law has been vaguely comprehended by the more illustrious writers on jurisprudence; but their ignorance of the ceonomic element has always prevented them from grasping the true nature of the institutions of which we are speaking. Thus lhering regards the law as a compulsion exercised upon individuals by the collective authority, with a view to deterring them from excesses that would 
turn to their own disadvantage, which they themselves are unable to foresee. ${ }^{1}$ This definition, indeed, exactly describes the characteristics of the law in so far as it applies to the relations existing between the members of the capitalistic group, upon whom the law actually imposes a series of acts that are in conformity with their real interests; but it is not applicable to matters concerning the labourers, for they are obliged by law to act contrary to their real egoism. In the second place, this definition takes no account of the anomalous fact that individuals have to be constrained to act in conformity with their own interests; and it fails to see, that this contradiction must necessarily be the result of an abnormal and transitory economic system, under which acts that are in reality useful do not appear so to the individual and must, therefore, be dictated by some superior force. If, however, we turn aside for a moment from the capitalistic economy and fix our attention again on the final economic form, we will perceive that, owing to the transparent nature of the prevailing social relations, the individual is there able to recognise immediately the personal advantages and disadvantages resulting from the different acts he performs. A spontaneous fulfilment of the egoistic act is thus assured; and there is no longer any reason for psychological absurdity of its enforcement.

From all this it will be readily recognised that the legal system is much more complicated than the moral code. Morality, in short, requires no special institutions to guarantee its observance since it is left to the persuasions of conscience. But the law, on the other hand, demands a whole series of institutions to secure its fulfilment. Morality, besides, depends upon the work of a relatively restricted number of unproductive labourers whose business it is to preach moderation to the masses and the élite of society; while the law, on the contrary, employs a triple army of unproductive labourers: one branch to formulate the principles of justice, another to earry out these principles into practice, and the third to assure their execution; that is to say, there must be jurists, judges and police. From this

${ }^{1}$ ihering, Zweck im Recht; Leipzig, 1877-83, i., p. 250. 
we must conclude that the law is a phenomenon belonging to a more advanced stage of social evolution than morality, since it is a more complex and heterogeneous institution, corresponding to a more highly developed system of capitalistic civilisation. It is also a more costly system, and one to which capital only has recourse after it has experienced the inefficacy of the less expensive methods of safeguarding the persistence of property. ${ }^{1}$

Thus, as a coactive and imperative instruction, the law is likewise a necessary product of the capitalistic economy, serving to protect the income-holders from their own importunities and from attacks on the side of the labourers. ${ }^{2}$ It becomes thus at once the complement and the integration of capitalistic morality, wherever the latter proves insufficient.

This organic connection between the application of the legal sanction and the institution of capitalistic property finds its proof in the entire history of the law During the long period preceding the institution of the capitalistic régime legal penalties were never incorporated into material acts, and the purely abstract nature of the legal system finally gave rise to the theoretical illusion that a law could exist without its corresponding sanction. As a matter of fact, however, a law deprived of its material sanction is plainly an impossibility, since the essential characteristic of the law, and that which distinguishes it from morality, consists in just this material penalty. But though there cannot be a law without the existence of a corresponding sanction, one may still admit the possibility of a law without the exercise of its sanction, provided economic circumstances render it feasible to dispense with the necessity of resorting thareto. Now, just such circumstances are to be met with in an economy where equality of conditions prevails. Under such circumstances the application of the legal sanction

${ }^{1}$ The opposite thesis is upheld by Pellegrini, who regards morality as the integration of the law, and considers it accordingly as a later development in the evolution of social idcas (Diritto Sucialc, 1891, p. 14) But this is wrong; for the very rigidity, precision and complexity whish are the special characteristics of the law, of themselves denote it to be a more advanced institution than morality, and mark it as belonging to a later stage of human development.

${ }^{2}$ Cf. Vanni, Gei sludi di Sir H. Mainc, 1892, p. 46. 
is rendered superfluous by the fact that acquiescence in the law is to every one's interest. Under such conditions the law simply amounts to a tecbnical classification of the acts and abstentions that are to be the advantage of the citizens of the State; and, on this account, respect for the law is assured on the part of such citizens without the necessity of applying any penalties. Thus there is nothing extraordinary in the fact, that the primitive tribunals were simply courts of arbitration which left their verdict to the voluntary execution of the parties. The sanction becoming thus purely theoretical, it ended in being no longer even the object of a threat.

It is thus easy to explain how the non-exercise of legal penalties during this social period came to encourage the belief in the non-existence of such penalties, and consequently caused the jurist to imagine the possibility of the existence of a law without its corresponding sanction. The matter is also explicable from the fact that the non-exercise of the legal sanction continued even after the conditions of economic equality that first rendered this state of things possible ceased to exist. The non-exercise of the legal sanction for so protracted a period, resulted, in fact, in the atrophy of the social organs whose function it was to apply it. Thus at the outset of the capitalistic régime the sanction was but imperfectly applied, because the necessary organs were still inert or imperfectly developed.

The legal sanction was for this reason inadequate ${ }^{1}$ during the early days of capitalistic socicty, and primitive legislators had, therefore, according to Maine's profound observation, to accord to procedure an importance that seems to us out of all proportion, as modern legislators throw the prescriptions of procedure into the background. In early times the legislator had, indeed, to exert every effort to assure the rigidity of the legal sanction and to repair the insufficiency resulting from its practical disuse. This very inadequacy of the legal sanction during so protracted a period was, indeed, the cause both of its frequent violation and of its 'employment by private citizens. The revolts against the constituted judicial authority occurring during the middle ages and even in our day in some of the less

${ }^{1} C f$. Maine, Ancicut Law, and Vanni, Marine, p. $61 \mathrm{fi}$. 
civilised countries-the camorra and the maffia-are striking examples of the systematic violation of the legal sanction. On the other hand, we find no less remarkable examples of its employment by private citizens in the vendetta, so common during the middle ages and still actually in vogue in certain countries, and in the application of lynch-law in the United States. These two lines of phenomena, so diametrically opposed to each other, are both but the necessary products of a legal sanction that is inadequate in itself and imperfectly applied by the collective authority. It is only after the course of ages and with a constant improvement in its use that the application of the legal sanction becomes certain. Rebellion then becomes more rarc, and obedience to the law more regular. Thus beginning with that spontaneous submission to the law, arising from conditions of economic equality which made such conduct conformable to the natural interests of the agent, we reach a reflex obedience which is the product, not of natural egoism, but of the infallibility of legal penalties, which in turn assures the requisite transformation of egoism demanded by the property system.

If the law then constitutes the sanction that society, or more strictly, its ruling classes, accords to existing economic conditions, it must then of necessity reflect these same conditions, and docilely follow in the train of their successive transformations. The law, in other words, proceeds from the economic constitution and changes as it changes. The theory of Savigny and the historical school, which regards the law as the product of the national conscience, or the result of the peculiar inheritance and hahits of a people, is thus entirely erroneous. On the contrary, the legal systems of the most widely separated races and nations must be the same whenever the prevailing economic conditions are identical. On the other hand, every nation must undergo a change in its legal system when the onward march of its civilisation has biought about radical changes in its econonic constitution. 


\section{CHAPTER Il.}

\section{THE ECONOMIC BASIS OF LEGAL TRANSFORMATIONS. AN HISTORICAL DEMONSTRATION.}

Changes in the prevailing economic conditions necessarily involve corresponding alterations in the law. This is a truth that is evident from what we have already said, and the history of law furnishes us, besides, with clear and definite demonstration of the fact. From the early dawn of juristic life, during that primitive period when the law was worked out upon a family and not upon a property basis, mother-right prevailed among the most profoundly different peoples, and in the most widely separated places. The maternal family, with its complicated system of relationships, flourished alike in Asia, Greece and Africa, as well as in prehistoric America. When we come down to times that are less obscure and to facts that are more definite, we are again struck with amazement at the profound similarity in the legal systems prevailing among the most different peoples during these early historical periods. We know, as a matter of fact, that the ancient laws of the Romans, the Irish, the Gauls and the Germans were practically the same, or presented but imperceptible divergences. Among these different peoples the law shows us the same classification of persons, the same absolute character of marital and paternal authority, a like constitution of the family and an identical distinction between the ager publicus and the ager privatus. In each of these countries the law maintained the inviolability of private property, determined the boundaries of the patrimoniai fields, proclaimed the personal nature of an obligation and fixed the rigorous bonds that shackled the liberty of the debtor and transformed the security pledged into a right of property. In all four cases, finally, the law insisted upon respect for the 
sacredness of the oath, accorded ample confidence to the witness and arranged for the intervention of judicial warranties.'

Germanic law, it is true, founded property rights in the family, while Roman law accorded such rights to the individual; but in the primitive Roman law there are also many traces of the earlier family community. That so striking an analogy should exist in the legal systems of two peoples so profoundly different and so widely separated is a highly significant fact and one worthy of serious consideration; on the one hand because it radically $r$ zverses the theory that regards the law as an emanation of the national consciousness, and on the other hand because it shows that the law necessarily depends upon existing economic conditions. The Romans and the primitive Germans were profoundly different in race and manners and lived under different climatic conditions. Between these two peoples and these two lands there was, indeed, nothing in common beyond the identity of their economic systems; or, to put it more definitely, there was nothing in common between them except identical territorial conditions, which irresistibly impelled them to adopt an identical economic constitution. It is perfectly evident that this profound analogy in the legal systems of these two peoples could not have been the product of conditions wherein they differed, and must, accordingly, have resulted from the one element common to them both, namely: their economic system.

Thus the Roman economy and the German economy proceeded together for a certain time at about equal paces along the lines of their respective development. But after the collective economy gave place to the system of capitalistic property, based upon the suppression of the free land, their ways lay' apart ; for Germany's free land, being of a low grade of fertility, could be taken from the labourer without resorting to very serious violence, while in Soutlem Europe, on the contrary, where the land was of an exuberant fertility, a rigime of blood and iron could alone succeed in preventing the labourers from establishing themselves on the free land. Now this viofent suppression of the free land accomplished by means of slavery

${ }^{1}$ Laferrière, Histoire du droit Français, Paris, 1846, ii., p. $168 \mathrm{ft}$. Mnine, Ancient Law. 
served in Southern Europe as the foundation for an admirably perfected capitalistic system upon which a corresponding legal structure had to be raised. The phenomena of redistribution in particular, that is to say, the complex relations prevailing among proprietors, called for legal relations equally as subtle pan complex. It is not surprising, therefore, that such economic conditions engendered a system of legal relations and corresponding doctrines that remain to our day a superb monument to Latin genius.

From this point of view Roman law bears a striking analogy to English political economy. The former was the product of the complex relations prevailing among slave owners, while the latter was the outcome of the no less complicated relations springing up among modern capitalists. Both were the natural fruits of a country where egoism reigned supreme and of a people actuated by none of the softer sentiments. The only difference between the two systems consists in the fact that the Roman law only traces out the technology, while English political economy reveals the very physiology of human egoism. The law accordingly presents a more superficial character, corresponding to an earlier stage in the development of scientific thought, which can only proceed to more profound researches on reaching maturity. And just as classical political economy is a reflex of the economic situation surrounding the wagesystem, so the Roman law was an ideal product of the economics of slavery. A like legal system could never have arisen out of conditions of economic equality nor could it have been raised upon a patriarchal basis.

As soon as the slave economy began to disaggregate, the classic law fell into abeyance and another legal system, more in harmony with the new economic form, took its place. This period of legal decomposition and recomposition is of extraordinary importance, and confirms our chosen theory in the most striking manner. We have already observed that the slave economy was never established in all its rigour in Teutonic countries, and that from the very outset the suppression of the free land there assumed the milder form of serfdom. Thus, while the slave economy prevailing in Southern Europe en- 
gendered one set of legal relations, an absoiutely different legal system, based upon serfdom, was established in the countries of the North. The latter legal system differed from that of Rome in three respects: it instituted and sanctioned patriarchal relations between property and labour; it protected the serf from arbitrary acts of violence on the part of the proprietor, and it placed respect for the family and the sentiment of solidarity above the mere satisfaction of a brutal egoism. ${ }^{1}$ In the course of time Southern Europe was also obliged to introduce the serf system, and it then became expedient to substitute the Germanic code, which was the outgrowth of the serf economy, for the classic law of Rome that was the product of slavery. The national law of Italy thus sank into abeyance and came to occupy a subordinate position beside the barbarian codes which were henceforth to prevail. ${ }^{2}$ This change, as we can readily see, had nothing to do with the victory of one national code over another. It was simply the natural reproduction of a legal system already determined for the purpose, to meet the reappearance of the very economic conditions that had originally given it life. We have thus additional proof of the law's absolute independence of national character, and its exclusive dependence upon the economic structure of society.

The introduction into medireval Italy of economic conditions similar to those prevailing in primitive Germany thus brought with it the barharian codes of the Teutons. And in a somewhat analogous manner the later institution in Germany of economic relations similar to those formerly prevailing in Rome introduced the Roman law into that country at a subsequent period. This latter phenomenon, which has so puzzled legal historians and still forms a stumbling-block to the Savigny school, loses its anomalous character when regarded in the light of the theory

${ }^{1}$ Cf Schmidt, Der principielle Unterschicd zwischen den römischen und germanischen Rechten, Rostock, 1853, p. 272 ff.

${ }^{2}$ By the twelfth century "Roman jurisprudence and the books of Justinian had fallen into oblivion in ltaly, and the code of the Lombards, held full sway" (Giannone, Storia civile del regno di Napoli (1723), Italia, 1821, i., pp. 289-911. 
which looks upon legal revolutions as the necessary concomitant of economic change. ${ }^{1}$ The wage economy that grew out of the old trunk of feudal society engendered, it is true, an absolutely new set of relations between property and labour, and these in turn had consequently to give rise to legal institutions heretofore unknown. But the system of redistribution instituted under this new economic form, though it differed widely from that prevailing during the feudal period, offered a profound analogy to that of the slave economy. Thus though the law regulating the labour contract had to be an original creation of the new economic system (or at best an elaboration of the contract of feudal ${ }^{2}$ service), the law regulating the relations among proprictors could practically be reproduced in its classic Roman form. Now it is exactly these relations between proprietors that constitute the essential object, and form, as it were, the organic tissue of the law, while the relations between property and labour only enter in a subsidiary way. Thus the organic and vital side of the law could be regulated by the principles of the jus romanum. The Roman law accordingly emerged from the tomb where it had so long reposed into the expansion of a new life. The movement toward this awakening commenced in Italy where the wage economy first began to develop, following the expropriation of the cultivators. The new and more active economic relations that were springing up in the industrial cities of the Italian peninsula soon became incompatible with the narrow rigidity of feudal law and communal customs, and accord-

${ }^{1}$ Dankwardt very well remarks that the introduction of the Roman law into Germany-which according to some could only have been effected by missionaries after the manner that a new religion is imported and propagated-was really occasioned by an alteration in relations of fact, which made the ancient German code no longer possible (National-oekonomisch-civilistische Studien, Leipzig, 1862, pp. 19-30).

${ }^{2}$ In Roman law the contract locatio conductio operarum, which was not even protected by an action, was applied in the very rare cases where a freeman hired out his own services, and in the more frequent instances when the slave owner rented the labour of his slaves. But personal relations were more common in feudal law, and we, consequently, come more often upon contracts of service under the feudal system. It was these, therefore, that the new law turned to account (Handworterbuch "der Staatswissenschaften, vgl, Arbeitsvertrag). 
ingly necessitated the institution of a legal system more rapid in its workings and more subtle in its movements, and such a system was found already elaborated in the Roman law. ${ }^{1}$

This renaissance of the Roman law in Italy was thus the natural consequence of the new economic system which introduced relations of redistribution analogous to those of the slave society; and the successive ramifications of the Roman law from Italy into Germany was again but the necessary corollary of the economic revolution that spread these same conditions throughout northern Europe.

The introduction of this foreign law into Germany was not, however, effected without intense opposition, and it, indeed, contributed not a little to embitter the very economic relations of which it itself was the product. We find proof of this in the German peasant's intense hatred of the new law, a hatred so deadly and implacable that it recalled to the brilliant civilisation of the renaissance the rage with which the German warrion pierced the throat of the Roman jurist after the defeat of Varus,

${ }^{1} \mathrm{Cf}$. Lcrminier, Introduction générale à lhistoire du droit, Brussels, 1836, p. 139. Maine likewise (Ancient Law') sces in the development of economic conditions the cause of the modern renaissance of Roman law and of the substitution of individualistic law for feudal law. Even Savigny recognises that the earlier re-establishment of the Roman law in Italy "was duc to the prosperity and flourishing condition of the eities. This system lad, in fact, to be revived in the cities and hy the cities. It was not, therefore, by chance but through the necessary course of events that Roman law was re-established in the Italian cities, whence it passed on into France and Germany to correspond to like needs" (Storia del diritto romano nd medio evo, Turin, 1859, i., p. 130). Truly one could not affirm with greater clearness the economic basis of the law. And in several other passages in his work this illust rious author further recognises the fact. Thus, for example, in speaking of the legal system established in Italy toward the close of the barbarian invasions, he says: "Had landed property been taken from the Romans, the preservation of the Roman constitution would therewith have become inpossible. From the permanence of the Roman constitution, one has therefore to presume the permanence of landed property among the Romans" (Ibid., i., p. 198). Now in thus affirming that the persistence of cconomic conditions makes the persistence of legal conditions a matter of eertitude, the auther praclically adnits that the latter are the necessary product of the former. 
crying, "Now viper, hiss again if you can!"1 Nevertheless it would be an unpardonable error to regard the new law as the cause of the modern capitalistic system and all the crying injustices that accompanied its formation, since the new code only sanctioned and gave legal expression to economic conditions that were already in existence.

Thus legal history shows us that instead of being the product of abstract reason, or the result of national consciousness, or a racial characteristic, the law is simply the necessary outcome of economic conditions. ${ }^{2}$ For this reason a definite legal system may pass on from one nation to another and leap from an earlier to a later century, whenever its corresponding economic system is transmitted from this people to that and from one historical epoch to another.

After this rapid survey of the history of the law, let us now examine the various juristic institutions, and we shall there find additional confirmation of our main thesis.

${ }^{1}$ Grimm, Deutsche Rcchtsalterthïmer, Göttingen, 1854, Preface, xi. Eichhorn, Dentsche Staats-und Rechtsgeschichte, Göttingen, 1819, ,iii., p. 337.

2 "Property is the principal faetor in the development of the law." Thus Stein expresses himself (Französische Staats- und Rechtsgeschichte, Basel, 1875, p. 15). On page 369 of his work Stein, however, introduces an ideal element in to this evolution, namely, the idea of the State. 


\section{CHAP'TER III.}

THE ECONOMIC BASIS OF DIVERS LEGAL INSTITUTIONS.

Moders law, as we have just scen, is only really modern in its subordinate elements, in that portion, namely, which pertains to the relations between property and labour; and this is due to the fact that these secondary relations now assume a form unknown to former times. In its fundamental lines, however, that is to say, in everything that touches the relations among proprietors, modern law is but a reproduction of the Roman law; and this is the case, because these more important relations practically reproduce the earlier Latin structure. We have already demonstrated the relation of dependence existing between legal systems and economic conditions, by noting the constant recurrence of the same legal system whenever the corresponding economic conditions were reproduced. If we now make a careful analysis of the various legal institutions we will discover that they, too, are each and every one the necessary product of particular economic conditions.

\section{1.-The Law of the Family.}

Let us first examine the law of the family. The transition from primitive promiscuity to that earliest form of familial aggregation, known as the maternal family, was brought about by an increase of population, and the consequent need of augmenting the means of subsistence through organised cooperative labour. This necessity of forming an association of labour, however imperfect, inspired in the mind of the primitive man the idea of uniting into distinet groups individuals, who had up to this been in the habit of wandering at will from place to place. These groups were constituted, and at the same time 
circumscribed, by forbidding intermarriage among their menbers, and by compelling the women of each group to select their husbands from a foreign group. Within the familial clans thus constituted, the children always belonged to the clan of the mother, and consequently to a different clan from that of the father. In this way individuals belonging to different clans, but all collected around the same maternal head, were able to establish a primitive labour association. The maternal family was thus the first means employed to concentrate the labour of several individuals upon a definite territory. It constituted the first limitation placed upon the dispersive tendencies of savage life, and effected the first improvement in productive force.

But this prehistoric method of associating labour soon gave evidence of its multiple defects. It resulted in the dispersion of the masculine element of each clan over a vast territory, and brought together upon a restricted area a number of men belonging to different clans who owed obedience to different powers, and consequently were little inclined to work together in harmony. Production was thus confronted with serious obstacles, which became more and more difficult to overcome as the increase of population necessitated greater productive force. In the end, therefore, the maternal system had to give way to the paternal family. Under this latter organisation it was the men who sought their wives among foreign tribes and transmitted their name and descent to their children. ${ }^{1}$

The institution of the paternal family was also necessitated on other grounds. When subsistence could no longer be procured except by labour, the younger and weaker members of the family finding it impossible to produce enough for their nceds were forced to recognise that their very life depended upon the labour of the older and stronger nembers of the group. The existence of the women and children came, in short, to depend henceforth upon the labour of the man, and he, therefore, naturally acquiréd economic, and therewith also legal power over those who owed him their life. Henceforward the supervision of the family-which in prehistoric times had

'Sieber, loc. cit., p. $351 \mathrm{ff}$. 
rested with the mother-became the privilege of the father, and he acquired therewith a despotic right over his wife and children. The husband now prevented his wife from having any further intercourse with other men (thereby destroying at a blow the primitive polyandry), and subjected her to his authority in all the acts of her life. Over his children likewise the father exercised a limitless patria potestas, and practically assimilated them with his slaves. Now the sovereignty exercised by the father over the members of his family is in reality but an extension of the prevailing economic relation between property and labour, and for this reason it is bound to become modified as this economic antithesis is softened. Thus in the slave society the wife and children were legally the slaves of the husband and father, while in the feudal economy they found themselves rather in the position of his serfs and vassals, and in our modern wage economy, and especially among the poorer classes, they assume the position of his employees. Thus as economic relations change, domestic relations have likewise to be modified, and as Georges Sand has so profoundly observed, proprietors as well as labourers carry over into their domestic life the same relations of authority which they exercise or submit to in the outside world.

The institution of private property exerted still another important influence upon the constitution of the family. The complicated system of relationships growing out of the maternal family, which gathered so large a number of individuals about a common head, could only prevail belore there was any such thing as private possessions. As soon as the idea of private property arose the bond of relationship ceased to be represented by a community of sentiments and aspirations, and became embodicd in the economic relation of hereditary suceession. Thus when this institution was once firmly established, the maternal family with its innumerable host of relations became clearly intolerable, since it necessitated the division of the heritage among an enormous number of consanguins. The institution of private property consequently truncated with a blow the multiple ramifications of relationships growing out of the regrime of collective property, and replaced them with a 
simpler system of consanguinity and a more restricted form of the family. ${ }^{\mathrm{l}}$.

Finally succession in the paternal line was necessary in order to allow the father to satisfy his natural desire of transmitting his possessions to his children; for under a system of maternal succession his property must have gone to his brothers, or to his sister's children. For all these reasons, the maternal family constituted the familial form correlative to the system of communal property; while the paternal family arose as the necessary corollary of private property.

But the influences exerted by economic conditions upon the constitution of the family are not confined to those here indicated. On the contrary, they are so numerous and so deep that a writer who devoted his whole life to the study of this question did not hesitate to declare that every stage in the evolution of the family is determined by considerations of property. ${ }^{2}$

\section{II.-The Law of Property.}

The influence exerted by economic conditions upon the law of property is no less important. Thus the distinction between the ager publicus and the ager privatus, to be met with both in primitive German law and in the Roman law, was but a survival of the era of collective property, from which these two peoples had but recently emcrged. The absence at this time of any distinction between movable and immovable property was the result of the unlimited extent of free land which allowed cultivated soil to be compared exactly with any other product of labour. And the rigorous law of property enforced during Rome's best days was again the product of the then prevailing economic conditions. But after production had received so serious a check as that imposed by slavery, it became more than ever necessary to exclude all other institutions tending to restrict the product, for a situation that was already unsatisfactory could not well be aggravated. It was inexpedient, therefore, to load the right of property with

${ }^{1}$ Cf. Morgan, Ancient Socicty, London, 1877, p. $168 \mathrm{ff}$.

2 Mac Lennan, Studics in Ancient History, London, 1886, pp. 136, 377. 
legal limitations, for these only offered further obstacles to the productivity of labour. In the end, therefore, property cane to assume the character of an absolute right.

This essentially economic reason for the existence of Quiritarian property appears also e contrario from the fact that the Roman law did not hesitate to place rigorous limitations upon the right of property whenever such action was rendered necessary in the interests of production. It was with this end in view that legal servitudes were established, as they afforded an opportunity of developing rural production. It was in the same spirit that permission was given to hunt over private estates, because the chase benefitcd extensive agriculture by destroying the wild animals that were wont to injure the fields. According to Ihering the peculiar provision of the Roman law which allowed him who had appropriated an object to return its price instead of restoring it in kind, also rested on economic grounds. In order to encourage the cultivation of the soil, it was further arranged that he who cleared an uncultivated area should become the proprietor thereof after a lapse of ten years. And it was also with an economic end in view that the usucaptio was introduced, which aimed at rewarding the spirit of industrial initiative by punishing absenteeism among landlords. The essentially economic character of this latter institution comes out still more clearly from the fact that it did not exist in countries where economic conditions rendered it unnecessary. The exigencies of Roman production, which had already become relatively intensive in character, made it expedient for the law to recognise such a right of property in him who had devoted his labour to a certain piece of land for a long period of time; but the agricultural conditions of the Orient, that were much more extensive in character and facilitated besides by the exuberance of nature, made no such demands, as production could proceed in a very satisfactory way without according any right of this kind. Thus in solemn contrast to the usucaption of the Romans stood the Jewish Jubilee, which disregarded everything that time and labour had added to the value of property, and assured its periodic return to the idle or absent landlord, 
Even in the Roman economy the limitations laid upon the rights of property with a view to increasing the rights of labour were effected by degrees, and only increased in number as production itself became more intensive in character. We can accordingly account for the gradual prevalence of the theories of the Proculeians, who maintained that the property right in the thing manufactured out of materials belonging to another was lodged in the maker, over those of the Sabiniens, who accorded this right to the owner of the original materials. This very prevalence betrayed, however, a prejudice in favour of the exigencies of production, and this prejudice also became more marked as production became more intensive. ${ }^{1}$ Primitive Romman law furthermore allowed the possessor in good faith of another's estate to be ejected by the rightful owner and even deprived of his property in the fruits. We can readily understand, however, what difficulties a rigorous application of this law would, in the course of time, place in the way of agricultural progress, and how it must have become necessary to guard the interests of the cultivator by some milder form of legislation. For this reason it was later provided that the fruits should remain the property of him who held in good faith. ${ }^{2}$ We can also recall another incident of the same order. The rigorous provisions of primitive Roman law that permitted and even encouraged the most signal bad faith on the part of contractual parties, became with economic and commercial progress a serious obstacle to all business transactions, because they gave rise to numerous tricks and subterfuges that prevented honest men from entering into contracts at all. With the growth of capitalistic property, the necessity was, therefore, felt of exacting good faith on the part of those entering into a contract, and of departing from the rules of the primitive strictum jus upon this subject. ${ }^{3}$

In general we may say that the jus gentium of the Romans was, in its entirety, the product of the development of their

${ }^{1}$ Oertmann, Die Wirthschaftslehre des Corpus furis Civilis, Berlin, 1891, pp. 27, 60, 71, 119, etc.

${ }^{2}$ Dankwardt, National-ockonomie und Furisprudenz, Rostock, 1857,i., p. 49,

${ }^{3}$ Schmidt, op. cit., p. 268; 
intensive economy, which compelled them to pay continually greater consideration to the producer's capital. Later on, during the days of the feudal economy, the liens placed upon property in favour of labour were provided simply with the idea of favouring production, which at that time required the $\mathrm{em}-$ ployment of assiduous, efficacious and, consequently, well-paid labour. A like thought inspired that set of servitudes, emphyteuses, quit-rents and the like, which encumbered property during the middle ages-and so true is this that the moment these provisions became an obstacle to production they were at once abandoned. Thus in medizval England, the right of pasturage upon the uncultivated lands of the seignorial demesne formed an integral part of the feudal lord's grant, because without the exercise of this right the cultivation of land was impossible. But with a change in agrarian conditions, this right, instead of favouring agriculture, became an obstacle in its path, and it was accordingly abolished. ${ }^{1}$ In short, all those strange rights attached to feudal property constituting what are spoken of as banalities (moulin banal, four banal, etc), the right of chase, and others of a like nature, were but products of conditions inherent in the medixval economy, for, seeing their income constantly curtailed, property owners had to arrogate to themselves all sorts of lucrative rights and privileges in order to increase their revenue.

\section{1. - The Law of Inheritance.}

The influences exerted by economic conditions upon the right of succession are still more interesting. When regarded from the economic standpoint the singular evolutions of this law are not so difficult to follow. The fundamental principle that has determined the course of hereditary succession is as follows: During the primitive period when property belonged to the family, succession was necessarily $a b$ intestato as the several members of the family group already enjoyed a right of property or condominium in the common professions. But the motive

'Blackstone, Commentaries on the Laws of England, London, 1854, ii., p. 36. 
that led to inheritance $a b$ intestato disappeared upon the institution of the slave economy and the introduction of private property. Other reasons also argued in favour of according the proprietor the right of disposing of his goods upon his death. Slavery, as we have seen, placed serious obstacles in the way of production and accumulation, and these obstructions had to be overcome by the creation of some counteracting force equally as powerful. Among the forces applied to this purpose nothing was so effective as the right of testation, which excited the desire of accumulation and finally rendered it insatiable. Thus the individualistic character of slave property and the bounds it set to production together resulted in the appearance of the testament.

But continued accumulation aroused all the antagonisms inherent in the slave system and ultimately threatened universal impoverishment. Thus there was no longer any reason to stimulate production, and the desire arose to confine the opportunities for accumulation within narrower bounds. Numerous exceptions were therefore made to the freedom of testation, and the right was further limited to a part of the testator's possessions. At a later period, when slavery was succeeded by serfdom, some of the conditions of the primitive economy were reproduced. Holdings of serf-lands were not granted to the individual but to the family, to be handed down undivided to succeeding generations. This was due to the necessity of allowing the soil that had been so exhausted by slavery to recuperate through continuous and careful cultivation. Thus the exigencies of agriculture necessitated inheritance $a b$ intestato for peasant holdings. The political nature of feudal property introduced a like necessity for seignorial holdings, since the jurisdiction accompanying the property right of the early middle ages rendered it necessary that the estate should not pass out of the family, inasmuch as the family was the depositary of political sovereignty and answerable for the same to the king. Sovereignty, moreover, was essentially monarchical and could not be divided among a number of lords. Thus the property right which constituted the basis of such sovereignty had likewise to be transmitted to but one of the sons or de- 
scendants. Hence the right of primogeniture, so general during the middle ages, was, as Adam Smith remarked, the product of the political power inherent in property. Its end was in no wise to deprive some members of the family of their share in the common heritage, but simply to entrust one of them with its administration and jurisdiction. ${ }^{1}$

And even after the right of property ceased to carry with it political power, other reasons entered in to limit the heritage of landed property to a single descendant. Collective inheritance $a b$ intestato was compatible enough with the primordial economy, where the several members of the family worked together and jointly administered their common possessions, but the arrangement became intolerable after the growing spirit of individualism had induced the several co-heirs to dismember the family heritage to the injury of production and economic life in general. The necessity then arose of immobilising the land in the hands of one of the descendants. Herein also lies the explanation of the survival of the right of primogeniture, and of the fidei commissa after the downfall of the feudal system, and the tenacious persistence of these two forms for so long a period. In this connection it is also interesting to note that while the evolution of inheritance ab intestuto proceeds from institutions that tend to dismember property (by dividing it up among the legitimate heirs) and makes for institutions, like the fidei commissn that succeed in concentrating it, the course of inheritance by testament, on the contrary, proceeds from institutions that tend toward the concentration of fortunes (by transmitting them to a single heir), and makes for institutions that tend toward their disintegration, by dividing up the legal reservation among all the nearest descendiants.

Inheritance $a b$ intestato was thus the prevailing form of succession in the serf economy, because the advantages of the testament in encouraging accumulation were far outweighed by the advantages secured through inheritance ab intestato,

${ }^{3}$ Adam Smith, Wealth of Nations (standard edition), p. 305. Miaskowski, Das Erbrecht und die Grundeigenthumsvertheilunge'n in Dentschen R'ich, 1.eipzig, !885, ii., pp. 44, 201, 253, ete. 
which favoured a restorative cultivation of the soil and transmitted political power uninterruptedly in a definite family group. But the reasons that led to inheritance $a b$ intestato vanished with the disappearance of the serf economy. After the labourer had been deprived of the possession of the soil he cultivated, and there was no longer any connection between property and labour, the transmission of the holding within the proprietor's family circle was of no further interest to the producer, and consequently carried with it no advantages to rural production. Like other productive enterprises, agriculture found itself benefited by the testament, which was at that time encouraging capitalistic production and accumulation. It is thus easy to understand why the right of testation was revived with the institution of the wage economy, and became the normal corollary of the property system, for the accumulation of wealth and its subsequent concentration in the hands of the few proceeded more rapidly under this impulsion. But as was the case in the slave economy before, so now the process of accumulation under the wage system came in time upon obstacles which it could not surmount without provoling general disaster. It was thus to the public's advantage to set bounds to capitalisation and enrichment. For this reason freedom of testament had again to be limited, because it encouraged too much accumulation. It was at this juncture, accordingly, that the institution of the legitime was re-established, which had originally been instituted toward the close of the slave economy.

This alternate development of inheritance $a b$ intestato and the testament is written indelibly in the history of the law. Thus in primitive Germany inheritance was $a b$ intestato, and the heritage was handed down ipso jure to all the members of the family. Inheritance $a b$ intestato was likewise the rule in primitive Roman law, and the testament-which in itself was an exceptional act needing a special law to invalidate it-was resorted to in the early days simply with the view of assuring a portion of the family heritage to the emancipated sons, who, according to the strict law, would otherwise have been excluded. ${ }^{1}$ 
Even to-day in Russia the peasants recognise nothing but inheritance $a b$ intestato, because all the nembers of the family jointly cultivate the paternal property and regard thenselves in consequence as the possessors of a right of condominium in the estate. But in western Europe the introduction of the slave economy gave rise to testamentary institutions. Upon the decline of this economic system, however, and with the decomposition of the capitalistic cconomy, these institutions, in turn, came to be limited by the institution of the Falcidian portion. As the slave economy gave rise to testamentary succession in Italy, so the serf economy revived inheritance $a b$ intestato in Germany, and grafted on to this old trunk the right of primogeniture and the fidei commissi. These latter institutions afterwards spread out over the Latin world as well, when the serf economy took root there among the ruins of slavery.

When the free land could be suppressed automatically, serf. dom finally made way for the wage system, and the testament appeared again in ltaly to start on a fresh course of development. The barbarians themselves adopted all the provisions of the Roman law relative to testation with the single exception of the Falcidian portion, which, it should be remarked, they emphatically repudiated.' And why was this? Simply because this provision was an expedient to check dangerous and excessive accumulation, and it had therefore to be thrown aside at an epoch when, as was the case during the early days of the development of the wage economy, the normal process of accumulation was barely sufficient to satisfy the needs of production. From Italy the testament passed on into Germany, where the older feudal relations were likewise undergoing a process of disintegration to make way for the institution of the wage economy. This process continucl until the growth of an abundant fund of capital-always an element of crises and disasters-made it necessary to impose a series of progressive checks upon accumulation. Limits were then set to the right of testation, and more stress came to be laid upon the importance of inheritance $a b$ inlestato through the institution of the legitime.

${ }^{1}$ Glasson, Mistoire du droit [ctc.] de la France, 18s7, iii., p. 188. 
Economic science thus furnishes the simplest and most natural explanation of the evolution of the law of inheritance; while legal philosophers, too often ignorant of economic principles, have never succeeded in making it accord with their systems. The theories of Gans and Lassalle are the most ingenious legal philosophy has to offer us on this subject.

Gans regards inheritance $a b$ intestato as the result of necessity and the testament as the product of liberty. The former system thus predominated in the east, where the seeds of liberty never germinated, and it also prevailed in the early days of Rome before liberty was born. But as soon as the ideal of liberty took root and spread, it caused testamentary institutions to bloom throughout the Latin world. But this theory fails to explain how it was that the Germanic world-which according to Gans himself represented the completest expression of liberty -so long ignored the right of testation. Nor does it explain why, upon the abolition of slavery, this right was also suppressed in the Latin world itself. ${ }^{1}$

Lassalle, on the other hand, looks upon the testament as a phenomenon peculiar to ancient Rome, a product, in other words, of the psychological stage that this nation was then passing through. The religious concept peculiar to this epoch was the immortality of the will, symbolised in the myth of the God Lar, or the idea of the continuance of the spirit of the defunct in the house after his death. But the carrying out of the deceased's wishes must have given rise to an impossible condition by subjecting the patrimony to the will of the dead, thus paralysing all effort on the part of the living. To obviate this difficulty the institution of the testament was interposed, whereby the defunct abdicated his rights over patrimonial

${ }^{1}$ Gans (Das Erbrecht in scincr woltgeschichtlichcn Entwicklung, Stuttgart, 1835 , iv., p. $214 \mathrm{ff}$.), it is true, says that the German system of inheritance constituted a step in progress in comparison with the Roman system, because in the former the will of the individual no longer operated against the sacred rights of family, and only exercised itself after family rights had been satisfied. But this does not interfere with the fact that the system countenanced a backward step in the freedom of the testator, and by no means constituted a factor of progress in his direction. 
affairs and invested them in his heir. It was thus the latter who was left to carry out the wishes of the deceased and prolong as it were the original individuality. ${ }^{1}$ But, adds Lassalle, the human mind, in the course of its evolution, finally broke away from its earlier belief in the immortality of the will, and rose to the higher conception of faith in the immortality of the soul. Now this new faith excluded all desires on the part of the deceased in regard to earthly things, and thus severed the connection that the testament had established between the will of the testator and the heritage. This at once demonstrated the absurdity of desires that were supposed to cease with this life continuing to direct and command temporal affairs after their own extinction. Thus the historical and psychological reasons for the testament disappeared, and henceforth inheritance had by the very nature of things to be $a b$ intestato. Such, accordingly, was the system which was established and became general throughout the Germanic world. But why then was the testament re-established in Germany toward the close of the middle ages? This, Lassalle concludes, was entirely due to an error on the part of the jurists of the time, and to a false application of the Roman law which the human mind when better informed must sooner or later set aside. $^{2}$

Thus according to this ingenious philosopher the modem will is the result of the error of some sage. This all important institution, entering so closely into the economic life of the people, had its origin in the caprice or ignorance of some doctor of law! Such are the conclusions and such the absurdities to which we are led by following a theory that endeavours to deduce the law from the nebulous regions of myth instead of allowing it to proceed naturally from the prosaic but real world of economic fact.

1 Lassalle, System der erworbcnen Rechte, Lecipzig, 1S61, ii., p. 10 ff. Fustel de Coulanges also deduces the testanent from religions concepts, and declares that it was unknown in the carly day of Rome simply because it was incompatible with the primitive religious beliefs of the Roman people (La cité antique, l’aris, 1890, p. 87).

${ }^{2}$ Lassalle, loc. cit., ii., p. 497. 


\section{IV.-The Law of Contract.}

Passing on from the law of inheritance to the law of contract, we come upon fresh proof of the law's dependence upon economic conditions. The personal basis of obligations, the sanctity of the oath, and the absolute faith in the testimony of the witness, were, as we have said, common characteristics of German and early Roman law. Now the personal basis of obligations was rendered necessary from the existence of free land, which excluded the possibility of the wage system, and, consequently, compelled the capitalist to take advantage of his debtor's insolvency in order to reduce him to a condition of servitude and so obtain his profits. This important legal phenomenon has, accordingly, been reproduced among all peoples possessing an abundance of unoccupied fertile land. It prevails to-day in Africa, where the law makes the insolvent debtor and his descendants the slaves of the creditor so long as the debt remains unpaid. ${ }^{1}$ The probative force of oral declarations was, on the other hand, a product of the open brutality and the absence of all fiction prevailing in the slave economy. In the midst of the wage economy falsehood, indeed, reigns supreme and covers with a mantle of justice the injustices inherent in such economic conditions; but fiction was unknown to the slave society, whose economic relations were openly based upon force. It is thus easy to explain why so great faith was accorded to the given word in this society, and how evidence came to be accepted as proof. ${ }^{2}$

A still more suggestive comparison next demands our attention. Even a superficial study of the rent-contract reveals a substantial difference between the condition of the Roman tenant, who only held a jus ad rem (which was, however,

${ }_{1}^{1}$ Post, Afrikanische Furisprutenz, Leipzig, 1887, i., p. 90.

2Ihering (loc. cit., ii., 608) has judicicusly remarked that the lie is only punished when it is socially injurious, and that it is not so, for example, under the despotic régime, because'lying is then a necessary condition of social existence and individual tranquillity. But the economic despotism that is founded upon the exclusive appropriation of the soil likewise makes lying a condition precedent to individual and social existence, and therefore leads also to its impunity. 
somewhat enlarged during the later days of Rome through the action of the pretor), and that of the modern tenant, who possesses (at least according to a well-recognised authority) a jus in re. Now the cause of this difference lies in the dissimilarity of conditions existing in the slave economy and the wage economy. In the slave economy only the most fertile lands were reduced to cultivation, "and this practically excluded economic rent. Hence it was impossible that a progressive increase of the revenue from this source should ever induce the landlord to evict his tenant in order to obtain a higher rent. Upon the introduction of the wage economy, however, a difference arose in the fertility of the different lands under cultivation, and economic rent consequently entered in. The upward tendency of this return offered an inducement to the proprietor to break the contract with his tenant as soon as the amount of the economic rent excceded the amount stipulated in the lease. The condition of the tenant was thus rendered precarious, and the uncertainty affected cultivation injuriously. The necessity thus arose of providing for the exigencies of production by assuring the tenant a position that was securer and less exposed to the arbitrary acts of the landlord. We notice the first timid manifestation of this tendency in the provisions of the Code Napoleon which accorded the tenant a jus in re. ln England and lreland still stronger provisions were adopted for the purpose. Thus English legislation recognises a right of compensation in the tenant for improvements worked into the land, while in lreland the redemption of the rent-charge is allowed, that is to say, the substitution of the tenant for the proprictor. In this manner the legal form of the rent-contract was substantially altered under the pressure of economic conditions, which rendered the ancient form no longer compatible with the normal advance of production. At first exposed to the arhitrary will of the landlord, the tenant came gradually to encroach upon the position of the proprietor and threaten his rights.

Economic evolution has, moreover, long since resulted in the application of the principle of redemption to the perpetuat lease or emphyteusis. Indeed, the greater the augmentation 
of production, the smaller became the proportion that the nixed rent bore to the total income of the estate. The economic power of the emphyteuta thus increased at the expense of the proprietor, and it thus became comparatively easy for him to have the right of redemption introduced by statutory enactment. This right of redemption was besides vigorously demanded in the interests of production, as agriculture was otherwise fettered by a perpetual lien that burdened the soil and interfered with the liberty of contract. With the increase of population and economic progress this antagonism became more marked, until at last it determined the destruction of the ancient legal form and introduced a new practice and a new theory of the perpetual lease.

It would be easy to show in a more general way how all the important and really fruitful legal reforms have been carried through with a view to advancing economic evolution. Thus, beside the redemption of the rent-charge that we have just been speaking of, the abolition of a legal rate of interest, and of imprisonment for debt, the publicity of the mortgage, and the free alienation of land, were all legal reforms rendered necessary by a change in economic conditions. But though it be a fact that the law is thus metamorphosed with every readjustment of economic relations, it is nevertheless true that this transformation is effected very slowly and only after a considerable interval has elapsed. Thus our present legal system has already grown rigid, and seems, as it were, to be stricken with a kind of paralysis. This is simply due to the fact that it is no longer inspired with economic life, and thus fails to respond with sufficient readiness to modern demands. Frequent contradictions are thus apt to occur in applying the law of the past to the present economic situation. The new conditions to-day entering into rural industry call for agrarian contracts that are more elastic and more favourable to the labourer, but the law, wrapped in its dark mantle of Roman formalism, still holds fast to legal forms that have long since ceased to be applicable. This legal system, which is in large part the product of a past age, is even being applied in all its rigour to new colonial lands.- It is also the present desire to 
confine the contracts on the Bourse within the narrow limits of the Roman law. The German system of the land register, an invention so well adapted to facilitate the free alienation of the soil and the raising of mortgarges, is frowned upon by jurists because, forsooth, it does not enter into their traditional formulas. The landlord's legal rights over the tenant's farming implements lilicwise constitute a serious obstacle to the introduction of an agricultural credit system. The Code Napoleon (as Pelegrino Rossi has already remarked) and the Italian Code both evince an unjust partiality in favour of landed property, according it an excessive importance no longer compatible with the development of personal wealth.

There is thus a sorry contrast between economics and our modern legal system, which no longer answers readily enough to the exigencies of conomic cvolution. The law is thus defeating its own ends; for insteal of facilitating the existing relations among proprietors and lavouring the development of property, it often places obstacles in the way of its own expansion.

\section{V.-The Law Regulating the Relations between Masters and Workmen.}

The legal forms thus far mentioned deal exclusively with matters pertaining to the redistribution of wealth. It is the object of these provisions to repress all violations of the right of property arising among the owning classes, and establish such relations among proprictors as are calculated to favour the extension of capitalistic property. Now this part of the law presents a deep impress of equity, and thus gires countenance for the moment to the idea that the law is indeed the realisation of justice. But this is simply due to the fact that these legal provisions regulate the affairs of men who are economically equal-or at least enjoy a liberty of choice-and among whom usurpation is excluded. But as soon as we turn our attention to the legal provisions regulating the relations between proprictors and non-proprictors, we perceive at once that our former concept was but an infantile delusion; for this side of the law shows us an obstinate, inpulent and thorough consecration of privilege and a decisive preference for property rights. 
So long as property was founded upon slavery, the usurpatory character of the law was not accentuated, because the labourer was excluded entirely from legal relations, which then only took account of the affairs of proprietors. We may therefore look in vain through Roman law for the exhibition of any hostile intent toward the labourer. And yet the law brutally proclaimed its inherent character by affirming the entire institution of slavery to be contrary to the laws of nature. In our modern epoch, on the contrary, capitalistic property is based upon the exclusive appropriation of the soil, and accordingly has no motive in suppressing the legal personality of the labourer. Modern law thus reflects the usurpatory nature of its origin and clearly betrays its emanation from capital. This fact appears very clearly from the law's unremitting care for the fortunes of the masters, and from its no less constant abandonment of the workmen's interests. The truth is shown again in the complete liberty that the law accords to property in its dealings with labour, in striking contrast with the multiple checks it places upon the reciprocal relations of proprietors.

Upon this point a comparison between modern and mediæval law is enlightening. During the middle ages when capital was weak and labour acquired its strength from the existence of free land, the law came to the assistance of capital by regu. lating the labour contract in a manner hostile to the labourer's interest. In our times, on the contrary, when capital is strong and labour is deprived of its liberty of action, the law amply fulfils its office of guardian of property by abstaining from regulating the wage contract at all, and leaving it to the dictation of capital. Following the transition from the systematic to the automatic economy, the labour contract has thus descended from its former condition of being regulated in a capitalistic sense, to a position beyond the reach of the law entirely, where it is now handed over to the tender mercies of capital.

And does any one doubt that the civil code was really inspired in the interests of the richer classes? Matters pertaining to redistribution or the reciprocal interests of proprietors are 
regulated with the utmost care. But as far as distribution is concerned, the wage contract is purposely left to the good pleasure of the capitalists, who are thus in a position to exploit the working men at their pleasure. The law's silence upon the rate of wages, and in regard to the manner, the form and the time of their payment furnishes the capitalist with the legal possibility of practising usury, and allows hin to pay his wages in damaged products, bad meats and the like. The lack of any provision to the contrary also permits the manager to sit as judge over the labourers under his control and inflict fines upon them freely and according to his own caprice. Jurists class such fines among the penal clauses of the contract, but, as a matter of fact, they are real penaities, and only too often serve as inequitable expedients for reducing the wage that is alieady too small. And at all events the result of such conditions is that the capitalist is at the same time judge and party to the suit! All the efforts that have been made to guarantee labourers an indemnity for injuries received during the course of their employment have met with systematic opposition on the part of jurists, who have succeeded in forging out of their classical formulas an insidious weapon which they employ against those who work for their living.

All the learned discussions over the violations of the labour contract clearly betray the capitalistic character of the law and its ill-will toward the labourer. During the course of the interesting controversies upon this subject in Germany, Lasker maintained that the contract being a matter of the civil law, its violation must come under the same head, and that, therefore, the violation of the labour contract ought not to be subjected to a penal sanction. But the sycophants of property were not in the least ashamed to uphold the opposite thesis. Thus his opponents argued that violation of contracts on the labourer's part ought to be the object of a penal sanction, hecause breaches of this kind endanger the internal security of the State; hut that violation of contracts on the part of the capitalists might he left to civil sanctions, hecause such offences do not compromise social security, and because in any event the capitalist can always make good any damage he may do! Let us hasten 
to add, however, that this Ultima Thule of sophism did not succeed in making its way into German legislation, and that up to the present the law has refused to take any explicit measures + against the labourer who breaks his contract. But what legislation is unwilling to do, jurisprudence has accomplished. Always amenable to the wishes of capital, jurisprudence has hit upon the proper measures, thanks to a sophistical interpretation of the existing law. The capitalist is, in short, allowed to hold back as much as a quarter of the wages due, in order to guarantee him against the contingency of a violation of the labour contract. So the net result of these learned discussions and these court-chicaneries has been cheeriully pocketed by the capitalists in the form of an increase of profits.

All the legislation concerning seduction and illegitimate children-matters which involve the violation of the honour of the poorer classes by the rich-is exclusively inspired in the interest of the latter, and tends to exempt the wealthy in every possible way from the consequences of their acts. The law reaches this result by forbidding the revelation of paternity, by refusing to give illegitimate children any right to the father's possessions, and by other such means. A fact particularly worthy of remark - and also of regret-in this connection, is that the rights of the poorer classes were much better protected under the absolute régime of the past than they are at present, for the government then succeeded to some extent in restraining the exactions of the bourgeoisic, while under the liberal rêgime of our day the upper classes are able to attain their complete satisfaction. Thus the provisions of the Prussian law born under the shadow of absolute power and imbued with pity toward the seduced woman and illegitimate children, excited the antipathy of the rich classes, and their paid advocates the jurists. So as soon as these classes acquired political power by the institution of representative government, they availed themselves of this opportunity to abrogate these well-intended prescriptions and substituted their own law of blood and iron - the law of the 20th of April, 1854.

And though debtors in easy circumstances are protected against usurious contracts, nothing is done to preserve the 
poorer classes from the most inhuman usury. The property of minors is placed under the strictest guardianship, but no steps are taken to protect their persons. For this reason poor children who have only their persons to dispose of are abandoned without recourse to the most deplorable abuse and pitiless expioitation. Finally by establishing the principle that ignorance of the law does not excuse without at the same time providing any way by which the poor can inform themselves of legal provisions, the civil code places the masses in a disadvantageous position and renders them an easy prey to the upper classes.

In regard to the general principles of the law our criticism would be still sharper. In general we should say that all legal aphorisms have been drawn up in the interests of the rich and strong and in contempt of justice and equity. "We might even add that the law in its entirety vindicates the assertions of Saint Simon de Clsampionniere (who was himself a jurist) and other impartial writers who regard lawyers as the most implacable enemies of the labouring classes and the most zealous defenders of feudal and capitalistic usurpation.

\section{VI.-Criminal Law.}

In passing on, finally, from civil to criminal legislation, we find the influences exerted by ceonomic conditions upon these legal phenomena are, if anything, still more sharply accentuated. We should also note that economic conditions here operate at once, and with equal force, upon the crime itself and upon its punishment. A lengthy demonstration is scarcely necessary to establish the fact that a very important class of crimes, namely, those against property, are the result of economic conditions and proceed directly from the misery that weighs so

'On these points of. Menger's very important Work, Das bürgerliche Recht und dir besitzlosen Classon (Arithir firr soziale Gisctzgebung und Statistik, 1889, 1890). Salvioli, I difotti sociali dit codtic civili, Palermo, 1891. Bechaux, Le droit it les faits économigus, Paris, 1S\$9, pp. 101, 156, 171, etc., and for the opposite point of view of. Nani, Il socialismo nel codice civile, Turin, 1892. 
heavily upon the larger proportion of the population in our richest and most civilised countries. ${ }^{1}$ And crimes which at first sight offer but slight evidence of correlation with the economic condition of the criminal, such as crimes against the person and crimes committed by the rich, upon more careful analysis also reveal their economic essence. It has been remarked, however, that crimes against the person are more frequent during periods when living is cheap and prosperity more general. The conservative school has hastened to conclude from this that a large number of crimes are independent of the economic condition of the criminal and the general distribution of wealth. ${ }^{2}$ But the error of this decluction becomes apparent when account is taken of the fact that an augmentation of material wealth only leads to foolish waste or criminal design when prosperity is precarious. Thus if the labourer profits by a rise in his wages to employ his funds in an illegitimate manner, or if, as Toynbee said, an augmentation of wages simply means an increase of crime, this is true only because the increase of wages comes in the way of an act of munificence from the

${ }^{1}$ Baudrillart has diseovered that the greatest criminality and the greatest frequeney of qualified thelits occur in the Department of the Eure, which is one of the most intelleetual and richest departments of France (La Normandie et la Bretagne, 1855). "With the diffusion of manufactures the number of crimes against persons diminish while those against property increase" (An Inquiry into the State of the Manufacturing Population, London, 1831, p. 9). Del Mar (History of the Precions Metals, London, 1880, p. 342) furnishes eloquent facts upon the influence exerted by the discovery of gold mines upon the increase of erime (and upon the increase of suicides as well). Levasseur (La popnlation française, ii., pp. $46,129)$ shows that the constant increase of second offences (and also of suicide) is the result of economic causes.

${ }^{2}$ Ferri, Das Verbrechen in seiner Abhïngigkeit von dem jährlichen Temporaturwechseln, Berlin, 1882. The fact alleged in the text has been recently contested by Silioy Cortes (École positive, February, 1892), who shows by figures take! from Spanish statistics that there is a constant parallelism between erimes against persons and crimes against property. Lux (Archiv fir soziale Gesetzgebung, 1892, p. $277 \mathrm{ff}$.), on his side, has established the fact that in Germany economic depression has not only added to the crimes against property but also to those against morality, by rendering classes less resistent to deleterious impulses. $C f$. also the striking remarks of Tarde, La eriminalité comparée, Paris, 1886, pp. 66-72. 
upper classes, and its essentially transitory character renders any wiser employment irrational. But the result would be very different if we had to do with a really lasting amelioration in the condition of the lower ranks of society. A betterment of this kind would have the inevitable result of raising the general standard of morality, and this in turn would introduce a greater power of resistance to deleterious appetites. ${ }^{1}$ As for the criminal acts of the rich, we must bear in mind that economic conditions exert a corrupting influence upon morals, not only through an excess of misery but also by a superabundance of wealth. The criminality of the rich is, therefore, not so independent of the influence of the economic environment as one would think.

But the anthropologists insist-and their argument is the strongest of all-upon the existence of a distinct criminal class, made up of born criminals. These natural criminals are driven to crime, they say, by reason of their physiological constitutions, and no mere change in economic enviromment could accordingly have any ameliorating eflect. ${ }^{2}$ These attempts to deduce criminal plienomena from anthropological antecedents give evidence, however, of an incomplete study of the facts. A more independent examination of the subject will show that these phenomena, insteac of heing the result of individual causes, are rather the outcome of general conditions acting upon socicty as a whole. And a little further study must convince even those who wish to premise a criminal type, that the physical characteristics of the criminal are by no means the product of natural and unavoidable necessity, but

1"Chaque citoyen possède-t-il quelque bien dans un Etat, le désir de la conservition est, sans contredit, le voeu gioniral de la nition. Le grand nombre, au contraire, y vit-il sans propriété, le vol devient le voeu frencral de celte méme nattion" (Helvetius, De fhomme, sect, vi., ch. vii.). See on this subject Ferri's excellent work, Sociologin crimnale, Turin, Bocea, 1892, p. 246.

"Mayliew has remarlied: "It is noticiable that the dangerous clisses of our cities, who are indeed valgahonds and saviges, preserst the same anthropological characteristies as nomad tribes, lilie the lialits, the Fellahs, etc, ; and especially in that their skulls slow a large development of the jalw-bone" (London Labour and London Poor, p. 4). 
rather the work of economic causes that have operated long enough to bring about degeneration in the criminal or in his ancestors. Prolonged poverty, hard labour performed by women during the period of pregnancy, malodorous and unhealthful dwellings, insufficient and anti-hygienic alimentation, alcoholism (the fatal corollary of idleness among the rich as well as among the poor), spasmodic work for varying and uncertain wages, the dissolvent influences of indolent and inactive wealth-all these prepare the way for deep degradation which, lasting through a number of generations, can perfectly well manifest itself in external characteristics and anthropological anomalies, inevitably leading to crime. Criminal anthropologists, and in particular their illustrious master Lombroso, look no farther than the asymmetrical cranium, or the projecting ear, or epilepsy, and attribute criminality to these factors. The imperfection of the logical process is apparent, for it does not inquire into the causes that led to the asymmetrical skull and the other anthropological peculiarities, which they are content to regard as mysterious phenomena derived from some atavic reversion more mythical than the Indian Trimurti. The theory fails, in short, to recognise that these anthropological phenomena constitute simply the last detritus and external indications of a long erosive process worked out by economic conditions, mercilessly operating upon human life.

Crime being a morbid emanation of capitalistic conditions, tends to interfere with their normal functions, and the punishment of crime is thus the legal means employed to consolidate and protect these same relations. Penal sanctions have, accordingly, followed the alternate prevalence of the different forms of ownership and favoured the entire evolution of property. Thus an agricultural state metes out its heaviest penalties to crimes against landed property, while a commercial state punishes most severely the crime of issuing false money. Severity against theft, again, is an indication of the prevalence of movable over fixed property. For this reason primitive Roman law proceeded with great severity against thieves, while under the code of Justinian the rigour of the early law was considerably 
modified. And in general each state proceeds most severely against the crimes that injure its predominant interests. ${ }^{1}$

But though the law varies thus in its predilections toward different forms of property at different cpochs, it is nevertheless always constant in its partiality toward proprietors. It is, indeed, scarcely necessary to insist upon this point, as the best criminalists have already vigorously denounced the essentially capitalistic character of the law of punishment, with its constant solicitude for the privileges of property and its total abandonment of the poorer classes. To be sure, jurists now recall with indignation that under the Salic law the punishment for the theft of animals was visited more severely upon the poor than upon the rich $;^{2}$ some sociologists also regard it as an enormity that savages should punish theft more severely than homicide; ${ }^{3}$ and an Italian traveller has recently recounted with horror how theft and brigandage go unpunished among the Somali if committed on a large enough scale. But when we notice what is going on round about us, honestly compels us to admit that, in the matter of legal morality, we Europeans are not much above the Somali. Pelegrino Rossi has, indeed, deplored the fact that in a civilised country like England the indulgence of the law toward assassins should offer so striking a contrast with its severity toward thicres. But the same contrast is to be met with among all modern nations, and the system of punishments generally in force in the most civilised countries of the world certainly deserves no less decisive condemnation. Bismarck also deplored the fact that in matters of money the law shows an absolute rigour, contrasting strangely with its relative indifference to questions of health, life and honour. The Italian code, likewise, inflicts very severe penalties upon theft and proceeds with vigour against strikers; while it treats

'Wilman, Die Rezeftion des römischen Rechts whd die sozinlle Frage, Lcipzig, 1890, p. 40.

${ }^{2}$ Glasson, Histoire du droit [etc.] de la Frunce, 1887, ii., p. 567. Among the Marea, likewise, an African tribe, 1 he 1 hief, if he be a nohle, is only obliged to return the thing stolen; hut if he be a man of the people, he is con. demned to give up everything that he possesses (post, loc. cit., ii., p. 89).

${ }^{3}$ De Greef, Introduction à la sociologie, Brussels, 1886, ii., 267. 
with manifest indulgence a large number of crimes especially characteristic of the richer classes. On this point the learned criminalist Ellero has expressed himself as follows: "Theft under certain aggravating circumstances has to be expiated by twenty years in the galleys, while for swindling five years in prison suffice, one year is the penalty for violation of the domicile, and six months for outrages of chastity, while under certain circumstances these crimes are merely punished by a fine of five hundred francs. ${ }^{1}$ I understand full well that swindlers deserve all the consideration possible-especially when they become millionaires-but it would seem, nevertheless, as though domestic peace and modesty-even though these things are good only for the miserable-should be rated a little higher than five hundred francs. And how does it happen that the petty thief has to expiate a fault that may presuppose great degradation, but not necessarily perversity of character, much more severely than the dastard who tramples upon the most sacred joys of humanity. In short, the entire civil code is in favour of the rich and in opposition to the poor; it guarantees the bourgeoisie and abandons the proletariat." P. Rossi also has remarked: "The upper classes of society simply look upon criminal justice as an instrument to be directed against those whom they speak of as the multitude or herd-in other words, the people," 2 and a writer of our day concludes: "The office of criminal law up to the present has not been to protect society as a whole with all the various classes that compose it, but more particularly to defend the interests of those under the favour of the constituted political authority, or in other words, the proprietors ". 3

Thus under all its varied forms the law constitutes a very powerful means of preventing reaction among labourers and of

1 These facts are taken from the penalties laid down in the Sardinian Code. The new Italian Code has reduced the punishment for qualified theft to eight years of confinement, and raised the penalty for outrage of modesty and for violation of the domicile to thirty months.

2 I borrow these quotations from Colajanni's substantial book on Criminal Sociology, Catania, 1889, vol, ii., pp. 648, 658-61.

${ }^{3}$ Vaccaro, Genesi e funzione delle leggi penali, Rome, 1889, p. 101. 
assuring the continued existence of property. ${ }^{1}$ It follows from this that the decomposition of the capitalistic economy must involve a corresponding crisis in the legal sy'stem. At every period of social decomposition a dissolvent, accordingly, works its way into the law and changes its elements. Thus in our day a growing current of aversion has set in against the excessive individualism of the law. The opinion is also gaining ground that this individual tendency ought to be checked by the intervention of the social element, that the right of property might be progressively limited by law, and that the jus abutendi should be forever abolished.

Now whence comes this critical tendency in modern law? It is simply a product of that slow process of social disintegration which is day by day rendering our dominant economic form and its legal manifestations more intolerable. This modern criticism of things in general has already eaten its way into our vitiated economic system, and is now forcing upon us the necessity of building anew. The confused conditions of our economic life have thus laid the law open to criticism as well. But a glance reveals to us the antagonistic and contradictory character of this latter critique; for it is endeavouring to introduce into the law, which is essentially an individualistic production, the social element, which is heterogeneous and therefore irreconcilable with the suggested reform. An analagous and equally contradictory critique appeared toward the decline of the Roman cconomy, when the organic dissolution of economic relations caused a reaction against the exclusiveness of the Quiritary law and gave rise to the idea of tempering its severity with milder provisions. In fact in every case it is always the same causes which produce the same effects. Over against the comparative perfection of the legral system resulting

${ }^{1}$ These remarks and these facts show again the perversion of the theory that endeavours to derive conomic conditions from the law. I have opposed this theory for fourteen years while it was still in vogue (sec my Rendita fondintia, Mlilan, 1:379, chap. vi.). It would not be fais to combat it any further now that it has heen abandone.l $y$ its own parti-

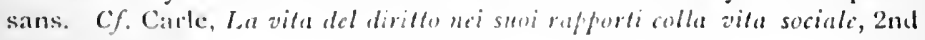
ed., Turin, 1891. 
from a relative equilibrium of economic relations, there is always to be set the imperfect and hybrid character of the law during the critical periods of society when the shock of the social elements, warring together in the undercurrents of economic life, give rise to counter conflicts between tendencies and elements in the field of legislation. We need not be surprised, therefore, if the coming social revolution which is now assuming such alarming proportions should determine a corresponding crisis in the law. The adumbrations of this event are already apparent, and in the near future we may expect to witness still more interesting phenomena. This last legal crisis will not pass over until a new and adequate social system is established, wherein the law of equality shall prevail. The law will then no longer constitute the justification and support of privilege, but will rather stand for the consecration of labour.

To sum up in a few words what we have set forth in this second portion of our work: the law is really derived from economic conditions, and it is only in the light of the latter that we are able to understand the genesis of legal sanctions, the history of the law, and the real structure of its various institutions; the law is also a monopoly of wealth, and in the temple of Themis there is no place reserved for the labourer.

If capital desires to accord an irresistible and solemn character to the legal sanction, it must model the law after its own design and prevent the labouring classes from subsequently modifying it to suit themselves. To this end it is, however, essential for the capitalistic class to possess the necessary power to create the laws, and the requisite force to apply them. In a word, it behoves capital to gain control of political power. It is to this final conquest, constituting property's brightest crown and forming the most interesting page in its history, that we have now to direct our further studies. 


\section{PART III.}

THE ECONOMIC FOUNDATIONS OF POLITICS 


\section{CHAPTER I.}

ECONOMIC REVENUE AND POLITICAL SOVEREIGNTY.

Turnisg now to the politics of the final economy, we find that the economic conditions there prevailing naturally give rise to a perfect type of political democracy. The absolute equality in the incomes of the several producers-or the necessarily transitory character of such trifling incqualities as may arise -indeed, makes it impossible for one set of producers to acquire any ascendency over the others. The absence of class conflict does away, moreover, with the necessity of establishing a despotic centralised authority to restrain individual excesses. Thus where free land prevails the normal development of economic relations should in itself suffice to assure perfect liberty.

This appears most clearly if the free land determines the simple economic form-meaning thereby a spontaneous labour association between producers of capital and ordinary labourers. If, however, the free land, by reason of its high degree of fertility, engenders an cconomy of isolated producers, and if co-operation among such producers can only be effected through political force, then the state has to be endowed with absolute authority in order to triumph over the recalcitrant impulses of the various producers. Under such conditions, despotism is, therefore, the necessary political form. Not that species of despotism, however, which results from class privilege and is employed by the few to the injury of the many, hut a form of despotism that is at no one's particular service, and which, springing from the collective interest, employs itself to the advantage of even those against whom it is directed. Despotism, under such economic conditions, is simply an adequate means of allowing every one's labour force to acquire the 
highest degree of efficiency. It is thus an instrument for potentiating labour, and becomes in this way a means of enlarging and guaranteeing liberty.

But the conditions change radically as soon as free land ceases to exist and the capitalistic system is instituted; for the conquest of sovereignty on the part of the proprietors and the exclusion of the labourers from all share in authority constitute the conditions precedent to the existence of this form of property. This exclusive retention of political authority by the owning classes does not, however, result entirely from property's innate tendency toward expansion and limitless domination. It is also essential to the continuance of economic revenue; for it is evident that any extension of political authority to the non-proprietary classes would determine a course of collective action hostile to the income holders, and lead to the establishment of that socialistic polity which is at all times the dream of the disinherited and the nightmare of the capitalistic class.

This conclusion might be objected to on the ground that, at a certain stage of economic evolution, the suppression of the free land is in any event the condition sine quâ non to the association of labour and the onward march of civilisation. "On this account there would seem to be no reason to fear lest the labourers' participation in political authority should permit them to establish a different economic form; for even if they succeeded in destroying the capitalistic system, it would surely be resuscitated very shortly by way of a counteractive to the disassociation of labour and its disastrous results. But it is easy to see that such a restoration of the capitalistic system would after all bring but slight satisfaction to the recently expropriated, for the re-establishment of the capitalistic régime would not necessarily result in the reintegration of their former possessions. On the contrary, their property would much more probably constitute henceforth an appanage of the successful appropriator's.

Now it is just this danger of a change in the personality of ownership that urges the revenue holders to employ every means at their disposal to render the labouring classes sub. 
missive. Moral suasion and legal compulsion are resorted to in turn to attain this end, but whatever the efficacy of these earlier methods of control, partial insurrections on the part of the labouring classes are still possible; for by peaceful means they may still seek to obtain legal protection for labour and a more equitable distribution of the product. In order to check these insurrections a show of force is necessary, and in order to counteract these democratic attempts at legislative reform, capital has, as a last resort, to lay hold of political power. Political sovereignty thus becomes the ultima ratio of the property system. Now it is enough for the proprietary class to desire to lay hold of political power in order to insure it the monopoly thereof ; for the labouring classes, deprived of all choice in the matter, and compelled to solicit their very subsistence at the hands of capital, have no possible means of disputing this conquest of sovereignty. The labourers are thus compelled to uphoid this combination of political power and economic revenue, and in this way property's hold upon political sovereignty becomes an accomplished fact.

The appropriation of political authority is certainly the most costly of all the means employed by capital to lieep down the disinherited classes. To be effective it not only necessitates the institution of complicated political machinery, but it furthermore requires a much larger army of unproductive labourers than the moral and legal methods of compulsion. Property only has recourse to this system, accordingly, after long experience has demonstrated the imperfect efficacy of the two methods previously employed. It is not strange, therefore, that moral imperatives and judgments of legal tribunals have, in the course of history, preceded the institution of political society on a capitalistic hasis. Property, in other words, only attempts to substantially modify the stite after it has alreacly radically transformed morality and the law and fashioned them both in its own interests. But what though political power is thus, in point of time, the last of the social influences employed hy property, it is none the less vigorous, for it completely changes the political organism and converts the state into an infallible instrument of dominion and exploitation. 
The history of mankind furnishes striking demonstration of the powerful influence exerted upon the political constitution by the suppression of the free land and its outcome the capitalistic property system. And to demonstrate the truth of this fact it is not necessary to recur to the hypothesis of a "state of nature," as was the delight of the philosophers of the last century, for the development of our modern colonies has cast in striking relief the effects thus produced by the gradual absorption of the free land upon the constitution of the State. Adam Smith attributed colonial prosperity to two causes: the enormous extent of fertile free lands and political liberty. But the history of new countries--taking the United States as our example-shows us that these two causes may practically be reduced to one. Political liberty can, in short, only develop where there is an abundance of free land, and with the progressive diminution of this element freedom is gradually curtailed and eventually disappears. During the early days of America the colonial congresses expressed the sentiments of the entire nation, and the modest farmers who formed its nucleus sent men of their own stamp to represent their interests in these legislative assemblies. As Burke observed: "The people, by their being generally freeholders, and by their form of government, have a very free, bold and republican spirit". ${ }^{1}$ Toward the close of the last century another Englishman made this remark: "The British Parliament is made up principally of wealthy men, but the American Congress is composed of men chosen from the people. Their money never has any influence upon their election, and there is no example of electors allowing themselves to be corrupted, or of any attempt being made in this direction, for any such procedure would only result in arousing the indignation of the entire population." 2 Twenty years later the conditions were yet unchanged, and obedience to the will of the people still remained the essential principle of action of the American Congress. Thus, for example,

${ }^{1}$ Burle, European Scttlements, London, 1777, ii., p. 167.

${ }^{2}$ Letters on the Present State of England and America, London, 1794, pp. 117-18. Cf. also Lecky, History of England in the Eightecuth Century, i., p. $330 \mathrm{ff}$, 
when the people demanded an emission of paper money Congress had to yield." "The people, who possess the power in the United States, certainly have not accomplished half as many acts of injustice in their legislation against the rich as the British aristocracy has committed with its legislation against the poor." 2 Nevertheless " in New York the people pay onethird less and property pays one-fourth more than in England. Throughout the United States taxes are lighter upon persons and heavier upon property, while in England they are lighter upon property and three times as heavy upon persons. In New York the citizen has the right of vote, while in England one has to be a proprietor in order to enjoy this right. In a word, the great contrast between England and America consists in the fact that in America the masses make the laws and property pays, while in England, property makes the laws and the people pay." 3

But as population increased inequality of fortunes entered in, and with the growth of landlords and capitalists the American Congress came to be gradually filled up with representatives of the privileged classes, and the contrast between the real country and the country as legally constituted became continually more marked. Although every one recognised toward the middle of the century that "the labourer's influence in the American Government was powerful and irresistible," still people "began to note the beginnings of jealousy between the labourers and the capitalists, eager for power". ${ }^{4}$ After this things proceeded more rapidly, and political power soon became the monopoly of property. Thus instead of a Congress composed of great plebeians, constituting the legislative expression of the epoch of independent producers, we now find a Congress made up of plutocrats and agents of railway companies, forming the legislative expression of an epoch when capital predominates. Dr. Tocqueville, in his dense ignorance of the economic bases of $39-41$.

'Bolles, Financial History of the United States, New York, 1879, i., pp.

${ }^{2}$ Combe, Notes on the United States, Edinburgh, 1811, i., p. 351.

Johnston, Notes on North Amarica, l,ondon, 1851, ii., p. 254.

'The American Labourer, New York, 1813, p. 237. 
political authority, imagined that the political conditions of Europe would one day approach the purely democratic ideal worked out in America at the beginning of our century. But exactly the contrary has happened; for instead of European conditions coming around to the American democracy, it is rather the political situation in America that is approaching the European oligarchy so long established by economic conditions.

But the more rapid evolution of the colonies only allows us to trace the broad outlines of this political transformation accompanying the institution of capitalistic property. The slower and more complete development of ancient Europe malies it possible to analyse this memorable event more closely. If we turn our attention, accordingly, to the most perfect example of an economic community that history has thus far afforded - the Germanic mark-we will find that it was composed of a number of cultivators holding their lands in common and co-operating under a régime of perfect equality. Now this economic equality involved as its necessary adjunct political equality as well. All the members of the community took part in the assemblies which elected officers to measure off the fields and to act as rural police, which determined the amount of the impost and assessed every one equally, and which established rules relative to the rotation of crops and to the time of tillage and harvest. And all the co-associates owed absolute obedience to the enactments of the community. ${ }^{1}$ Under this ancient political form the State was not something apart from society; it was simply society itself organised. Collective authority proceeded naturally from the prevailing economic conditions, and the laws of the mark in the form of acts of joint sovcreignty were dictated by the very necessities of production. Reducing this political system to its simplest expression, we may therefore say that it was the requirements of production which made it obligatory for the communists to subject their liberty to certain restrictions in order to render their labour efficient. In other words, the exigencies of pro-

1 Maurer, Geschichtc dcr Markícrfassung, Erlangen, 1SE6, pp. 21, $57 \mathrm{ff}$, 
duction not only transformed the isolated producer, whose labour had up to this point proved inefficient, into a nember of a productive community, but also endowed this community with sufficient coercive power over all its members to develop an effective labour association. And though the liberty of each communist was henceforth subjected to restrictions, these limitations were in no wise imposed upon him by the authority of a higher caste, nor were they intended to promote interests that were forcign to his own. But in so far as he formed part of the collective will it was, on the contrary, he who suljected himself to such restrictions simply because they were necessitated by interests which he as a producer was bound to defend. Under this social form, therefore, a perfect system of self-government resulted from conditions of economic equality.

In cases where the purely democratic form of government proved incapable of associating labourers whose natures rebelled against political cohesion, a despotism was usually established which laid its yoke upon the entire population and rendered them all equal under a single tyranny. Thus the Asiatic despotisms were simply the outcome of this necessity of forcibly associating labourers - who would themselves never have voluntarily resolved to unite their efforts-in order to accord their work a greater efficiency and a higher degree of productivity. ${ }^{1}$ A tyranny of this kind is always founded exclusively upon the organic exigencies of production, and therefore responds to the interests of the people it dominates. It is, furthermore, atutomatically regulated by the existence of free land, which of itself renders the excrcise of true despotic authority inpossible so long as slavery is unheard of ; for the subjects always have a way of avoiding the oppressions of the sovereign by abandoning him and setting up for theneselves upon an unoccupied territory. It was in this way, for example, that the kihan of Bulsara, failing to take account of the possibilities thus afforded by the existence of free land, lost a large number of his Turcoman subjects, who, weary of his vexations, simply transferred them-

'Metchnikoff, La Civilisution at les grands flute's histuriques, Paris, 1889, pp. 224 ff, 
selves to the Government of the Khan of Khiva.' The gens society discovered by Morgan among the American aborigines was also ruled over by a military chief who was often a tyrant ; but his tyranny was precarious and always directed to the common good. ${ }^{2}$ In Trinidad, likewise, the Indians are ruled by chiefs who only exercise absolute authority during the periods of production, that is to say, when the tribe is engaged in hunting, fishing or in agricultural pursuits. ${ }^{3}$ Under such economic conditions it usually behoves the constituted authority to flatter his subjects in order to keep them under his jurisdiction. The despotic régime must thus be exercised in the peoples' interests and aim at preserving them from disassociation and its resulting barbarism.

Association of labour constitutes, therefore, the original foundation of civil society. But, at the outset, it does not necessarily mean private property; for, at first, co-operation usually accompanies the collective property régime. We can thus recognise at once the falsity of the assertion that the first man who subjected the soil to private ownership was the original founder of civil society. But though property be not the immediate concomitant of the social aggregate-which in reality antedates the genesis of property by several centuries -it, nevertheless, has considerable influence upon the constitution of the state. The institution of private property has, indeed, exerted a twofold influence upon the political constitution. By allowing the members of the same gens, heretofore united by communal property, to appropriate isolated and remote lands in severalty, the admission of the right of private property, in the first place, destroyed the ancient gentile nucleus and substituted the State based upon territory for the State founded upon the gens. From this followed an increase in the extent and population of the State; for its citizens had no longer to belong necessarily to the same gens. Nor were they any longer joined together in a compulsory labour

${ }^{1}$ Sieber, Essai sur la civilisation économique primitive, Saint Pétersbourg, 1883 , p. 440.

'Morgan, Ancient Socicty, London, 1877, p. 149.

${ }^{3}$ Sieber, loc. cit., p. 431. 
association, which of itself checked the territorial expansion of the primitive state and restricted the growth of its population to a limited number of men. ${ }^{1}$

But beyond this somewhat superficial change in the political constitution, private property with its natural outcome, the capitalistic system, produced a further transformation, important in a very different way. It concentrated political power in the hands of the proprietary class, and consequently introduced radical changes in the nature of sovereignty. Under the régime of collective property, the State differed very slightly from society, of which it was simply the organising force. But with the institution of private property and the concentration of political power in the hands of the proprietary class, the State suddenly severed its former connections with society, as a whole, and came to represent the interests of a mere fraction of the community. Thereupon two distinctly separate series of relations were established, one between the State and the proprietors, and the other between the State and the non-proprietors. As against the proprietors the State found itself, on the one hand, in a passive relation, inasmuch as it was the creature of their own making, and, on the other hand, in an active relation in so far as it placed certain restrictions upon their liberty. But these restrictions were laid down in the interest of the proprictors who composed the State, and they wcre besides of a far less exacting nature than those formerly imposed upon the members of the primitive society; for the proprietors, being exempt from labour, naturally avoided all the exactions that used to discipline the labour of the communists. The institution of property thus mitigated the restrictive action of the State upon the class which composed it, and accordingly extended the liberty of the proprietors.

'Morgan, loc. cit., pp. 264, 268. Lieber (loc. cit., p. 450), on the contrary, belicves that the change of sovereignty from the fentile into the territorial form must have been effected before the institution of private property, and as soon as exogamy had brought together upon one ierritory men belonging to different tribes, becaluse a State based upon the gens would have been unable to discipline these men in their reciprocal relations and unite their forces. 
The condition of the non-proprietors was, however, very different. The State stood entirely in an active relation to them, for it issued from influences that were foreign to their interests and subjected their liberty to such restrictions as it pleased the proprietors to impose, and the above-mentioned limitations that served the ends of the landowners in no way corresponded to the interest of the classes that were excluded from ownership entirely. Thus although the institution of property effected an enfeeblement of the State in its relations with its component parts, the proprietors, it brought about at the same time an extension of State authority over those who were now excluded from ownership. This latter dominion was still further increased by the necessity of holding the nonowning classes in obedience and preventing violent reactions, which, however powerless they might be to destroy the economic system, nevertheless disturbed the tranquillity of the opulent classes.

The extra authority that property thus transferred to the State with a view to holding the subjugated classes in check, often reacted against the proprietors themselves and limited their own privileges. The divisions among the various classes of proprietors (of which we shall have more to say in the following chapter) likewise tended to increase the power of the State and accentuate its effect in limiting property. But in spite of these exceptions it is still true that the institution of property lessened the coercive power of the State over proprietors ${ }^{1}$ and increased it over non-pro-

${ }^{1}$ Spinoza (Traité théologico-politique, Paris, 1842, i., p. 293) gives a well-chosen instance of this influcnce that property exerts in weakening the political system in relation to the class out of which the State is constituted. So long as the Hebrews remained nomads, he remarks, and everything belonged to all, they had a chief. But after the conquered lands had been divided among the tribes, and private property was instituted, the necessity for a common chief was no longer felt as the chiefs of the several tribes sufficed. Under such conditions only one of the two opposing influences exerted by private property upon the political constitution could manifest itself, because it was impossible for property to have any influence in reinforcing political power in the absence of a class of non-owners. 
prietors. For the former it therefore meant an extension, and for the latter a curtailment of liberty. Now the increase of power that the State acquired from the greater energy of its procedure against the non-owners more than counterbalanced the loss of energy sustained through its weakened position toward the owning classes. And this was the case because, under normal conditions, the non-owners far excceded the owners in numbers, and because the force directed against the former had to be very great in order to compel them to act contrary to their interests. Considered in its entirety, therefore, the power of the State was increased by the institution of capitalistic property.

With this augmentation in force, the entire organisation of the State also underwent a substantial modification. During the epoch of collective property either a patriarchal form of government prevailed, wherein authority was accorded to the oldest or wisest, or a military tyranny was established, which was elective and transitory in its nature and founded upon popular approval. But with the growth of capitalistic property these forms of government were rejected, because they were incapable of disciplining the class excluded from possession of the soil. The State that then appeared was capitalistic in character, and no longer permeated with the principles of equality. Henecforth the State no longer echoed the peaceful and equitable expressions of universal consent, but became in the hands of a rapacious minority a terrible engine of defensive and offensive warfare against the exploited majority. ${ }^{1}$

'Cf. Ferguson, History of Civil Socicty, with Hearn, The Ary'an Houschold, Mclhourne, 1879, pp. 322-25. Mory,an (loc. cit., p. 2(it) show's very clearly how the institution of eapitalistic property, or slavery, in Greece rendered the older political form, founded upon the gens and collective property, no longer tolerable and caused its destruction at the hands of Solon. The two latter writers, however, Hearn and Morgan, lefuse the appellation of state to these primitive forms of political government, and aflirm that the Stale only emerges upon the dissolution of the antique gens, upon the establishment of a fixed domain, and more especially with the institution of private property, making a cuercive power neces. sary to hold the lower order of non-owners in subjection. In this 
The great truth, already voiced by Hobbes, that wealth is power, because the holders of riches always appropriate to themsclves political authority, is common to the various historical phases of capitalistic property. It is the class that predominates economically that holds the political power in each historical period. Thus in the Greco-Italian world it was the slave-owning class, in the middle ages it was the fcudal lords, and at the present epoch it is the bourgeois proprietors who are politically supreme. The labouring classes, on the other hand, either found themselves brutally excluded from all share in political authority, as was the case in the ancient world, or at best they were given a nominal right of participation, like that exercised by the representatives of the bourgeoisie in the States-General of France, and by our modern labour candidates, who do not in the remotest degree threaten the political preponderance of the capitalist class. ${ }^{1}$

Nevertheless these different social periods offer marked differences in the manner in which the dominant class succeeds in excluding the others from all participation in the affairs of the State. During the epochs of slavery and serfdom the labourer was definitely excluded from political power by the same law that determined his economic bondage. But after liberty had been proclaimed, it became an absurdity and a contradiction to exclude the labourers any longer from political

matter of terminology (for it does not go beyond that) we do not, however, share the opinion of these historians, for it seems to us that the primitive elan and gens both show us, though in embryonic form, a political organisation, and, therefore, the institution of the State.

${ }^{1}$ In the French Chamber elected in 1885 there were but eleven labourers enrolled among the deputies, their number amounting to about $\frac{1}{t}=$ of the national representation. The number of working men deputies in the House of Commons elected in 1886 represented the same proportion. In the House of Commons elected in July, 1892, the labouring class had but two representatives. And even though the political representation of the labouring class exists thus in embryonic form, "the few representatives of labour who do get into the House of Commons arc there quite swamped and made powerless to move by the mass of landlords and capitalists around them (Webb and Cox, The Eight Hours Day, London, 1891, p. 178). 
rights; for the bourgeoisie, who had crushed out feudalism in the name of legal equality and were even then calling on these rights of equality to justify the economic system they were establishing, could not well make political rights a class privilege without traversing the very principles of their civic life. The labourer had thus to be excluded from political authority in some indirect way, and herein the cleverness of the ruling class showed itself anew. Thus in France the Constitution of the 3rd of September, 1791, established a distinction between citoyens actifs and citoyens passifs. Only those who paid taxes amounting to at least three francs were classed among the active citizens, while the rest, who were grouped together as passive citizens, were excluded from the right of suffrage. The Constitution, furthermore, regarded all those who worked for wages as passive citizens, and therewith denied political rights to the entire labouring class. In this way the suffrage was so restricted that in the Faubourg St. Antoine, for example, there were only 200 electors among 30,000 residents. And though temporarily suspended during the really popular period of the French Revolution, this law was reinforced under the Restoration. In the different states of Germany, three, ten, thirty or even more poor electors for a long time only exercised a right of rote equivalent to that of one wealthy landowner, and according to the law of the 3eth of May, 1849, 153,800 rich men possessed the same right of suffrage as $2,691,950$ workmen. The law of 31 st May, 1850, accorded the right to vote only to such citizens as had resided three jears at least in the place where they were at the time of the election, and, taking into account the frequent changes in domicile that modern industrial conditions require, such a provision was bound to exclude a large number of labourers from their right to vote. In regard to England John Stuart Nill wrote: "The present electors, and the bulk of those whom any probable Reform Bill would add to

ILassalle, Programme outricr in the Bibliotherque de l'Économiste. Lassalle, however, like Webster (Worlis, Boston, 1853, i., p. 33), thounht universal suffrage would prove sulticient to break down the political monopoly of property. Facts have proved him to be wrong. 
the number, are the middle class". 1 Even in the United States "the suffrage is far from being universal, as the poor and illiterate are excluded". ${ }^{2}$ Where Parliament is composed of two houses, it is sufficient, however, that the right of suffrage be limited to the election of one of the two legislative branches and not necessarily to both. Thus in a large number of the English colonies election to the lower house is by nearly universal suffrage, but for election to the upper house the suffrage is restricted to the landowners exclusively. As a result, reforms that are voted in the lower house are continu. ally being rejected in the upper. ${ }^{3}$

All these restrictions laid upon the right to vote-and we could cite many other examples-undoubtedly tend to disappear and give place gradually to universal suffrage, ${ }^{4}$ but even after this right has been established it is still easy for capital to maintain its monopoly of political power. If wages have already been reduced to a minimum, this is done by tyrannising over voters; but if this be not the case, the same result is obtained by corrupting those who are elected. After a series of economic influences (of which the most important is the declining productivity of labour) has resulted in reducing wages to a minimum, the labourer having no savings laid by finds himself completely at the mercy of the capitalist, who by threatening him with dismissal practically threatens his life. Henceforth the capitalist has only to condition the further employment of his employees upon their support of his candidate in order to dispose of their votes, just as the feudal lord disposed of the

${ }^{1}$ Mill, Thoughts on Parliamontary Reform, in the Dissertations and Discussions, London, 1875, iii., p. 37.

${ }^{2}$ Bryce, loc. cit., ii., p. 130 ff.

${ }^{3}$ Webb and Cox, loc, cit., p. 44.

${ }^{4}$ The elcctoral reforms in Italy in 1882 and the English reforms of 1885, for example, considcrably extended the political suffrage. Even to-day, however, universal suffrage is opposed by some writers precisely on this ground of the economic constitution of the State. A contemporary economist argues, for example: "Labour does not produce until it has already consumed a fund of pre-existing wealth. It is, therefore, economically dependent upon capital. It should, accordingly, be politically dependent likewise; ergo universal suffrage is unjust" (Philipp, The Function of Labour in the Production of Wealth, London, 1890, p.92). 
services of his vassals. ${ }^{1}$ And every one knows that this is a phenomenon of regular occurrence in all modern countries. Bagehot observes that in England "the great capitalists believe they are sincere in asking for more power for the working man, but, in fact, they very naturally and very properly want more power for themselves ". ${ }^{2}$ Not long since Herbert Spencer deplored the fact that in America twenty thousand labourers were guided at the polls by the will of a single entrepreneur, and that only the capitalist class was represented in Congress. And an impartial observer gives us the following account of the subject in modern Sicily: "As the landowners traffic in the minual labour of the husbandman, so they also dispose of his will. The peasants go to the polls in obedience to an order reccived from their patron or from the country magnates. The electoral reform has been a plague to the husbandmen, and has spread a new vice, the sale of votes, throughout the agricultural class." 3

It is, however, much more difficult for the capitalist to exercise undue political pressure upon his labourers after an increase in the productivity of labour has caused a marked rise in wages above the minimum of subsistence. To be sure, the cntrepreneur can, even under these conditions, threaten to dismiss

'This remark is attributed to a certain lord: "With limited suffinge 1 control six of my constituencies, under universal suffrage I would control them all". The Pall Mall Gazette of 12th November, 1855, offers the instructions given by Sir John Swinburne to the tenants on his Northumberland estates as a unique example of political disinterestedness: the linglish baronet forbade his agents to ask the agricultural labourers for whom they intended to cist their vote, or to milic any suggestions in this regard.

${ }^{2}$ Bagehot, The English Constitution, London, 1867, p. 203. Though recognising so explecitly that the working man's vole is dependent upon the will of the capitalist, this author, nevertheless, contradiets himself in the most singular way. He admits, indecd, that an extension of the suffrage to the agricultural labourers would only augment the political preponderance of the landed proprielors, but he denies that the same would be true of industrial labourers, for they, he thinks, would elect the representatives of their choice (pp. 218-20).

"Damian, Relazione in the Atti dellinchiestu agraria, vol. ii., No. 4, pp. 419-20. 
all employees who refuse to cast their votes for the capitalist candidate, but labourers who are able to support themselves on their savings during a period o idcress are not to be frightened by such threats, for they know full well that they will more than indemnify themselves for this brief suspension of wages under the new shaping of the State constitution that is to turn the balance of power in their favour. But capital succeeds in avoiding this fresh difficulty by other ingenious means. In the first place, capital can retain its paramount influence over the labourer's suffrage by buying their votes, either out and out, ${ }^{1}$ or indirectly, by making the rate of wages proportional to the number of votes the labourers give to the capitalist candidate. Thus when Mr. R. Boch stood for the district of Saar in Germany, the capitalists of the house of Billeroy and Boch divided their labourers, scattered among the different villages, into fourteen classes, according to the number of votes they secured in each village, and adjusted their wages proportionally. ${ }^{2}$

In the next place, the numerous expenses attendant upon an election render it increasingly difficult for those who are not especially well-to-do to obtain a seat in Parliament. ${ }^{3}$ And for this reason the great majority of seats are occupied by the rich. "There are said to be 200 members for the railways in the present Parliament. The Saturday Revicuo said, some years since, that the ability of Parliament was a protected ability; that there was at the door' a differential duty of at least $£ 2000$ a year." 4 The total wealth of the Senators of the United States reaches $600,000,000$ dollars, and each Senator controls the appointments in his own State, ${ }^{5}$ in that he recommends his candidates to the President, who feels morally obliged to conform to the suggestions. Seats in Congress and the Senate, as well as the Presidential office, are all open to the highest bidder in America, and consequently

In the month of November, 1888, during the election of the President of the United States, votes were sold in New York at fifteen, twenty and twenty five dollars apiece.

${ }^{2}$ Neut Zeit., 1s91, p. 633.

"Syme, Represcutative Government in England, London, 1881, p. 192.

"Bagehot, loc. cit., pp. 139, 209.

B Meyer, Ursachen der Amirikanischen Concurvenz, Berlin, 1883, p. 731. 
a monopoly of the wealthy. In one American State (Delaware) it is necessary to "own frcchold land of 200 acres or real or personal estate of the value of $\$ 1000 " 1$ in order to be a Senator. The Spanish Senate is exclusively composed of wealthy men. ${ }^{2}$

But it is not in this that capital's cunning is best exemplified: there are other means at its disposal. In fact, when capital can no longer prevent the labourers from electing the representatives of their choice. it cmploys itself instead in transforming these representatives into defenders of capitalistic income, buying up their votes so long as they hold their seats and indemnifying them handsomely afterwards for thus betraying their own electors, if these, by chance, have hecome indignant over their defection. Thus the people's representatives usually end by roting in favour of capital, as they reap advantages in this way which they could never obtain under a truly popular remime. Even in Australia, where the high rate of wages gives the labowiers a certain independence in electoral matters, the legislatures are composed of proprietors or their representatives, and legislation is inspired exclusively in the interests of property. This is possible hecausc capital succeeds in linking the people's representatives to its own fortunes. ${ }^{3}$ This condition of affairs is still more marlsed in the United States. To take one example among a thousand: ln one State an election was conducted on the platform of taxation of corporations. The popular party, which desired to see the companies taxed, happened to he victorious, and its representa-

'Bryce, American Commontealth, 3rd ed., i., p. 482.

2 Montero, El positivismo on la ciencia gruiridica [etc.] italiana, Madrid, 1891 , ii., p. 76.

${ }^{3}$ Dillec, Problems of Civeatir Brituin, London, 1890, P. 501. Wallace, Rural Economy of Austrelie, etc., Iondon, 1891, p. 297. We can sece from this that the remumeration of deputies, which is usually a part of all democratic schemes, must end in accentuating the omnipotence of capital, for it eliminates any fechle desire the people might have to replace the modern exonomic system ly anolher form which would necessarily preclude any such gross rewards. Phere is nothing. therefore, which is more thoroughty bourgenis than this legistation atiording remuneration to representatives. 
tives introduced a bill to this effect in the legislature. But the plan was defeated through the activity of a certain corporation counsel who had formerly been president of the convention of the popular party, and by the aid of the telephone companies' lawyer who had himself drawn up the original manifesto in favour of the taxation of corporations. ${ }^{1}$ Thus when capital is no longer able to prevent the election of popular candidates, it still succeeds in corrupting them and in transforming them into advocates of its own interests.

It is moreover well linown that the representatives of the American people are rapidly being converted into a venal class of politicians (already numbering some 200,000) who are but the tools and creatures of capital, and who, when they fail of re-election receive ample compensation in the form of offices and sinecures. "In all the great American cities there is today as clearly defined a ruling class as in the most aristocratic countries of the world. Its members carry wards in their pockets, make up the States for nominating conventions, distribute offices as they bargain together, and-though they toil not, neither do they spin-wear the best of raiment and spend money lavishly. They are men of power, whose favour the ambitious must court and whose vengeance he must avoid. Who are these men? The wise, the good, the learned-men who have earned the confidence of their fellow-citizens by the purity of their lives, the splendour of their talents, their probity in public trust, their deep study of the problems of government? No; they are gamblers, saloon-kecpers, pugilists, or worse, who have made a trade of controlling votes and of buying and selling offices and official acts. They stand to the Government of these cities as the Pretorian Guards did to that of declining Rome. He who would wear the purple, fiil the curule chair, or have the fasces carried before him, must go or send his messengers to their camps, give them donations and make them promises. It is through these men that the rich corporations and powerful pecuniary interests can pack the Senate and the Bench with their creatures."

${ }^{1}$ Ely, Taxation in American Sitates and Cities, New York, 1888, pp. 276-77. 
The bourgeoisie monopoly of power is no less general in Europe. In fact a Conservative member thus expressed himself in the House of Commons: "The people regard us as incomparable when it comes to the question of defending the cause of the rich and the powerful, but they consider us but listless legislators when it concerns the interests of the labourers and the disinherited". And it is equally the case in Italy, where wealth rules supreme over the elections and in the Government, as witness the words of one of her most illustrious authors, Villari: "Constitutional Govemment is in substance the rule of the bourgeoisie. The proprictary class is become the governing class, and in its hands are the municipalitics, the provinces, charitable endowments and the rural police." 1

We are thus able to trace a remarkable evolution in the methods employed to exelude the lahourer from political power. During the period of slavery it was the legal status of the labourer that shut him out of all participation in the government of the State. When the rate of wages is at its lowest, the exclusion of the worlsing man from political power is effected by means of this very depression of wages which subjects the labourer's rote to the decision of the capitalist. But during a period of high wages this exclusion has to be systematically obtained, first by laws restricting the right of suffage and then by allowing the people's representalives to share in the incomes and fortunes of captal. But though the processes be different the result is always the same; namely, the political monopoly of the proprietary class.

Changes of this kind in the economic constitution not only effect a corresponding differentiation in the processes whereby the labouring class is excluded from power, but also determine the different methods of appropriating and excrcising such authority on the part of the capitalistic class. Thus different

' Viliari, Lettere meridionali ad altri scritti sulla questione sociale, Florence, 1878, p. 48 ff. Turiello, Governo e Gozernati in Italia, Bohogna, 1890, i., p. 189) If. One of our hest deputies, M. (Giustino Fortunato said in the It:alian Chamber on I7th February, 1890, "Loria is, inded, right. All political systems and all gereromental comstitutions of whatever form are always conscionsly or uncon cinusly predommancly inspired in the interests of the social classes which direct the State." 
linds of revenue give rise to substantially different political systems. We should add, however, that this correlation of economic and political forms though normal is still not always so essential as to exclude the possibility of the existence of an economic system that does not correspond with the political constitution. Indeed when we realise that the political constitution is after all but a superstructure built upon economic conditions, we can readily understand how the latter may change without causing an immediate or perhaps any alteration at all in the former. Political relations are, indeed, but the involucel, the outer covering of society; and even as the same hat may fit the man of genius as well as the fool, so the most diverse economic forms can adapt themselves to the same political system.

And what we have said of politics applies equally as well to legal, commercial and even monetary systems. They are all superficial forms that may remain invariable, despite. profound alterations in underlying economic conditions. We have already noted the revivification of the Roman law upon the decay of the feudal system and its application with some important modifications to modern economic conditions. In the same way we come upon identical monetary systems and uniform commercial legislation at widely different economic epochs. And so too we may discover almost identical political conditions prevailing at periods that are nevertheless distinguished from one another by substantially different economic systems.

But though the superficial character of the political system thus allows frequent and important exceptions to this connection between the species of economic revenue and the form of political power, the correlation nevertheless exists ; and corresponding to the three principal economic systems-slavery, serfdom and the wage system-we find three distinct governmental forms.

While slavery prevailed, private law gave the proprietor absolute authority over the labourer's person, and it was not necessary to possess political power in order to acquire and augment the revenue from property. Under such conditions 
political sovereignty was only important to the proprietors as a means of guaranteeing the source of their income, and in order to prevent the economically subjugated class from instituting measures hostile to the capitalistic system. In order to attain these ends it was not necessary for the proprietors to possess any individual authority; for collective or class sovereignty was amply sufficient for the purpose. Nor was it essential for such sovereignty to be an exclusive privilege of the slave owners, since all freemen participated cither dircctly or indirectly in the property system. And though changes occurred in the internal composition of this small group of freemen who exercised active political power during the successive stages of the ancient economy-political dominion being first the heritage of patricians, and then opened to the plebs ${ }^{1}$-it was still always an economic sovereignty that prevailed, as the plebeians also participated in the property system, though to somewhat less extent than the patricians, and themselves constituted one of its essential supports. ${ }^{2}$ It is only when one appreciates the real character of these ancient societies where all freemen participated either directly or indirectly in the property system and consequently also in sovereignty, that one is able to understand the true nature of that ceascless struggle between the optimates and the people, which marks the course of ancient society. It was simply a struggrle among the several factions of the owning class to secure control of political power.

Property's monopoly of the sovereign prower in ancient times is also attested explicitly in the censuses of Solon and Servius Tullius, wherein property's political omnipotence was definitely decreed. And the fact is still more clearly estalo. lished in the words of Sencea: "It is the census that raises a man to the dignity of a Semator; it is the census that distinguishes the Roman knight from the plebeian; it is the census that determines promotions in the camp, and it is according to the census that the judge is chosen in the

'In Grece political power was a monopoly of the wealthy (Giote, History of (irece, l.ondous, 1861 , i., p. (i5). This was likewise true during the early day's of Reme, lhe rule of the plehs belonging to a hatce age.

"Sec on this point lontia's Anulisi, ii., p. $\$ 5$. 
Forum ".1 "In our country," said a Greek to Familius, " it is wealth that rules, and all else is subservient thereto." " "It is riches that malies the man, and he that is poor is neither honoured nor esteemed." 3

The political constitution of serfdom was profoundly different, as were also its economic antecelents. Physical control over the personality of the labourer was no longer compatible with the lower fertility of the soil. A more fecund social system was required, and therewith a milder method of suppressing the free land, in order to afford greater stability of conditions and to ameliorate the condition of the labourers. Subjection, it is true, increased in extent as a large number of freemen wcre now reduced to serfdom, or to a state bordering thereon; but it diminished, nevertheless, in intensity. Slavery, as we have seen, gave the proprietor an exclusive right over the person of the labourer, and consequently afforded him an opportunity of obtaining a maximum rcturn. But the new economic system, according the serf a right of property in the fruits of the soil allotted to him, and subjecting him to a fixed charge, made it impossible for the proprietor to acquire an increasing income. Thus in order to obviate conditions so disadvantagcous to the dominant class, it was necessary to transfer political sovereignty to the individual proprietor. This allowed him to impose charges upon his serfs under the form of tributes that he could not have extorted in the name of property. An alliance was thus effected in the serf economy between property and sovereignty. It was not, however, the owning class as a whole that now exercised sovereignty in the state, but each individual proprietor was sovereign over all who dwelt upon his estate. The proprietor was, however, in no position to engross political authority without allowing his clients, and more particularly the ecclesiastics, to have their share in the same. These men were necessary to guarantee the persistence of serfdom, and as, they participated in the revenue, they had also to share in authority. Political sovereignty was thus altered substantially with the modification of the revenue system. From being a collective privilege of freemen,

'Controv., ii., 5.

${ }^{2}$ Livy, xxxiv., 31.

${ }^{3}$ Aristodemus. 
it was transformed into a personal privilege of the individual proprietor with his clients and retaincrs.

When the appropriation of the soil became enough of itself without any direct action on the part of the proprietor to compel the working man to toil for the capitalist and leave him the greater part of the product, the theoretical freedom of the labourer was proclaimed. It was no longer necessary then for the proprictor to claim a right of private property in the labourer's person or to insist upon individual sovereignty, because the mere ownership of capital made it possible to secure the maximum profit without vesting the person of the proprietor with sovereign authority. Personal jurisdiction was thus again disassociated from property and collective or class sovereignty reappeared. This separation of property and personal sovereignty occasioned a revivification of the ancient répime, but with this important difference: in the antique world political power was apportioned among all freemen, as all shared either directly or indirectly in the property system; but in modern society liberty has no longer any necessary connection with property and consequently none with political power. Thus legal liberty implying, under the ancient régime, a participation in the property system involved a corresponding share in collective sovereignty. During the middle ages, on the other hand, the proprietor and his unproductive labourers were given individual sovereignty, because this alone made it possible to extort a progressive share from the productive labourers. But in our day legal liberty carries with it no participation in property and therefore involves no share in political power, so sovereignty now remains an exclusive monopoly of the actual owners and their unproductive labourers. It is, however, no longer uti singuli, as was the case during the preceling epoch, but uti universi, simply because individual sovereignty is no longer necessary to maintain the existing revenue system.

Not only is the method of appropriating political power thus definitely determined by the different forms of capitalistic income, but also the manner of exercising such sovereignty. The most important modification that capitalistic property has as yet undergone, and the change that has had the greatest 
influence upon the constitution of the State, is the transition from the servile to the wage economy. While slavery and serfdom prevailed the proprietor was freed by the very mechanism of the prociuctive system from the vulgar cares of accumulation, and could thus devote his whole energy to the affairs of State. The automatic process of production, such as we find in the Greco-Roman oikos, rendered it unnecessary for the proprietor to devote his labour and intelligence to private enterprise, and thus made civil life the end and aim of his activity. Hence the identification (if I may use such a term) between the citizen and the State in the ancient world, and the prevailing influence of public over private law (of the citizen over the man) which forms one of the most interesting characteristics of this period.

Under the wage system it is quite different. The proprietor is now compelled to intervene constantly in the mechanism of production and busy himself with the material cares of industrial enterprise. He is, therefore, forced to detach himself from active participation in public life and the struggles for political office. Individual activity in politics has thus come to succeed the political solidarity of ancient times. This clearly recognised contrast drew from Ferguson, Adam Smith's precursor, the following melancholy conclusion: "If the lot of a slave among the ancients was really more wretched than that of the indigent labourer and the mechanic among the moderns, it may be doubted whether the superior orders, who are in possession of consideration and honours, do not proportionally fail in the dignity which benefits their condition. If the pretensions to equal justice and freedom should terminate in rendering every class equally servile and mercenary, we make a nation of helots, and have no free citizens." " "We call it a Society, and go about professing openly the totalest separation, isolation. Otir life is not a mutual helpfulness, but rather, cloaked under the due laws-of-war, named 'fair competition' and so forth-it is a nutual hostility." 2

"Ferguson, loc. cit., ii., pp. 143-44. The same author adds: "How can he who has confined his views to his own subsistence or preservation be intrusted with the ènduct of nations?"

"Past and Prisent, 1\$53, p. 185. 
From this point of vicw we can distinguish four distinct epochs differing from one another in the relations established between the cconomic and political constitutions. During the period of collective pioperty complete political consolidation resulted from, and exactly corresponded to, the existing cconomic solidarity. Under the slave system the former economic solidarity gave place to an equally pronounced individualism, with its bitter conflict of opposing interests; but the older political solidarity stili persisted because the freenen were a!l jointly interested in the political collectivity, which was indceci a necessary element of their existence and part of their very personality. This was particuiarly true in the case of the Greeks, who had only recently emerged from the primitive period of collectivism. Thus Greck civilisation was characterised by marked political solidarity; whereas in Rome, where capitalistic property had heen estabiished for a longer time individualism broke through its bonds more readily. Under the feudal system cconomic conditions resumed their ancient consolidated character, but the political constitution was then characterised by the most pronouncel individualism-excepting of course the political solidarity of the free towns. Finally, in our day absolute economic individualism is accompanicd by political atomism no less complete, and the older community of interests between the citizen and the State has given place to the morc modern relations of mutual tolerance or indifference.

The most important phenomenon resulting from this metamorphosis of the servile into the wage cconomy is the institution of representative government. The direct excrcise of political authority was possible under the rigrime of collective property, because society was then divided up into distinct communities, which were limited in size and nembership. But the institution of capitalistic property, farouring as it docs the creation of large states, places difliculties in the way of such an exercise of political power and therewith prepared the way for the representative sy'stem. Nevertheless, so long as the original form of capitalistic property, the slave system, remained, direct government still persisted even in the 
largest and most populous States. Rome furnishes an example. Even in the serf economy the representative system only attained an embryonic form in the States-General, called together at secular intervals. In fact, in all history we only find one country where the great extent of territory rendered representative government necessary during the periods of slavery and serfdom, and this was the United States. The vast extent of the States at a time when the means of communication were but slightly developed made direct government a material impossibility, and thus occasioned the necessity of establishing the representative system. But even in the United States direct government still prevailed in administrative bodies so long as slavery endured, and it was only upon the institution of the wage system that it ceased to exist entirely.

These facts are readily comprehensible from the preceding considerations. Slavery and serfdom both tended to exclude the owning classes from productive activity and to concentrate their energies upon public life, whereas any system of representation would, on the contrary, have shut out the large majority of proprietors from the exercise of political power. Under such circumstances, therefore, representative government was thus logically impossible. The conditions were altered, however, when the wage system began to re-enlist the proprietor's energies in matters of industrial enterprise and accumulation; for the representative system then became a condition precedent to any reconciliation between the engrossing demands of production and the necessary participation of the owning classes in sovereign power. Hence England, which was the first country to institute the wage system, was also the first to establish the representative system. A long period of time elapsed, however, after the institution of parliamentary government in Great Britain before Germany emerged from the superannuated institution of the Curiae, each made up of a distinct social order, an'd only coming together in cases where extraordinary contributions were required to meet some public danger. ${ }^{1}$ Thus an alteration in the mechanism of ${ }^{1}$ Gneist, Geschichte der englischen Selbstverwaltung, p. 140. 
production brought with it an important, though not perhaps a substantial, modification of the political constitution, by repressing the direct form of govermment that had prevailed during the period of slavery and serfom, and replacing it with the representative system. ${ }^{1}$

The conditions inherent in the wage economy render it impossible, in short, for the large majority of capitalists to take an active part in the work of Iegislation, and compel them accordingly to delegate their political authority to men who belong to another class of society. But, let us hasten to add, this deputation detracts in no way from the political sovereignty rested in property, because the representatives chosen are either already dependent upon the propertied class or made dependent from the fact that they owe their election to its good pleasure. The choice of the proprietary class as a matter of fact usually falls upon the unproductive labourers, lawyers, doctors, professors and the lilie, and these men living upon the fruits of property, are not at all inclined to deny the principles of their existence. It is for this reason that unproductive labourers constitute the most numerous element in our modern Parliaments. It is true in conservative Holland the members of the elective bodies that constitute their Parliament are still largely recruited from among the wealthy cultivators; ${ }^{2}$ and cven in England, until recently, a large number of landed proprietors were regularly returned, hut this was evidently due to the fact that the mere acquisition of rent (in contradistinction to profits) requires no very assiduous attention to productive enterprise on the part of the landlord, and consequently opens up to him a broad ficld of political activity. Since the year 1880 the number of unproductive labourers in the British Parliament has, moreover, been constantly on the increase. In the French and I talian chambers they constitute an overwhelming majority, and in America this class, under the name of a strange

When Mommsen declares that the ancient democracies were founded in an error because they were not representative, he shows that he has not understood the economic basis of representative government or its dependence upon the wage economy.

${ }^{2}$ Laveleye, La Necrlande, Paris, 1865 , p. 132. 
variety of so-called politicians, practically makes up Congress, as neither planters nor directors of railway companies have time to spare for active politics. ${ }^{1}$ But to whatever class the nation's representatives belong, they are always dependent upon the property system, either because capital has bound them body and soul to its fortunes by graciously allowing them to share in its revenues and thus made them its unproductive stipendiaries, or more particularly because property, being sovereign over the elections, is able to dictate the political conduct of its elected representatives. It is therefore of much greater importance for the bourgeoisie to control the electors than the elected; ${ }^{2}$ for by disposing of the votes of the former they may be perfectly sure that the latter will never give voice to their own sentiments in opposition to the interests that determined their election, or, in other words, the interests of the capitalistic class.

It is, therefore, ridiculous to offer in objection to this theory of the economic composition of the State the fact that modern Parliaments are so largely composed of lawyers, professors, functionaries, higher officers, journalists and the like. It is ridiculous, I maintain, because none of these men really represent their own interests in the legislative assemblies, but simply support the property system, upon which they are

${ }^{1}$ Bryce, loc. cit., p. 171 ; ii., p. 392, etc.

${ }^{2}$ Would property be represented if the representatives of property were elected by men that did not possess a shilling? No; Arthur Young replied with his usual good sense: "The number chosen is of little consequence while persons without property are the electors" (Travels in France, 2nd ed., London, 1794, vol. i., p. 615, note). But this does not appear to be understood by those who offer in objection to our hypothesis that there are landed representatives who favour free trade and other measures of a like nature that would tend to reduce their rents; for they do not take into account that it is not so much the personality of the elected as the character of the class which elects that really counts. If this class gains any advantage from such democratic provisions, the landed deputy will vote for the democratic cause in order to retain his seat, which of itself compensates him for the loss of a small portion of his income. If, on the contrary, the electoral class be made up of proprietors, their deputy will uphold the interests of wealth even though he belong to the proletariat. 
dependent, either directly as its stipendiaries, or indircetly as its representatives. ${ }^{1}$

I will go still further. Far from the representative system weakening the political power of property, it is, on the contrary, the political organisation best adapted to assure the domination of the proprietary class. We will admit it sacrifices the individual by preventing possible excesses on his part, but it considerably strengthens the power of the mass. True, the bourgeois monopoly of political authority is identified under the representative system with the governmental majority, and consequently associated with the irreparable wealiness of social sovereignty. Hence arises the political paradox, that the progress of civilisation while it increases the attributes of the State, at the same time diminishes its force by allowing it to become entangled in the antagonism of the diverse interests prevailing among its innumerable collaborators. But the very weakness of the modern State is an advantage to the bourgeoisie, whose interest it is to lirrit collective authority in order, as individuals, the more freely to exploit productive forces. And this is precisely the reason why the fittest are so persistently eliminated from the management of public affairs in democratic States. ${ }^{2}$ This important political fact, forming one of the most significant manifestations of inverted Darwin ism and constituting a veritable sociological law of itself, is not altogether a product of the democratic spirit-as a distinguished writer would have it-but rather the resuit of the proprietary instinct, which is naturally rebellious against all energetic exhibitions of social power. In fact, ostracism of the politically fittest is the general rule whenever property is economically and politically strong. Aristophanes mentions it in a famous passage it profos of the

${ }^{1}$ The influence that the eapitalistic class exerts upon the choice of the electoral body often oversteps national boundaries. Thus, in 18.46 , the English mantacturers expended several million pounds sterling to have Polk, the frec-trade partisall, elected Piesident of the United States.

${ }^{2}$ laryce remarks that the most adroit and expert intrigners make their way in the Senate; that there is a natural selection of the worst (Bryce, loc. cit., ii., p. 166i); and we slould also note what this same writer has to say in regard to the vulgar type of politicians, statesmen and Presidents of the United States. 
conditions prevailing in the Greek cities, where he likens this law of politics, working toward the exclusion of the best men from the government of the State, to the economic law of poor money driving out the good. But during past epochs the economically dominant class always found itself compelled by the very necessities of self-preservation to establish a powerful government though it was bound to react eventually against its own interests. Indeed, the greater the labourer's subjection to the non-labourer, so much the more complete must the latter's servitude be under the collectivity, because the State has then to exercise increasing force in order to maintain its supremacy over the oppressed. This accounts for the omnipotence of the Greek and Roman States and the political subjection of their citizens. But the necessity for such an omnipotent State no longer exists in our day, because the labourer's bondage is at present effected automatically and without the necessity of proceeding against his person or violating his natural liberty. The ruling class can consequently fashion a Government that is entirely its creature, and an in. strument withal so fragile that it dare not oppose any resistance whatever to the class freedom of its authors. Herbert Spencer was therefore right in saying that representative government is the proper political form for the industrial type of society, and the system best adapted to perpetuate its processes. ${ }^{1}$

Not content with this successful assault upon political authority, and only rendered more audacious by success, the capitalistic class then proceeded on its triumphal march to conquer the military, administrative and judicial powers as well. At every historical epoch the capitalistic class has invariably dominated the army, because the commanding officers are unproductive labourers, chosen for the most part from the well-to-do classes, living at property's expense, and naturally interested in defending the system. The dependence of the administrative power upon the economic constitution shows itself likewise even in the smallest details. Thus the system of local government varies rhythmically with every change in the economic structure of society. Talie for example

${ }^{1}$ Herbert Spencer, Principles of Sociology, iii, , pp. 806 ff., 810. 
the United States. In the New England States, where the Puritan colonists established their small agricultural and manufacturing industries, the town formed the administrative unit; while in the Southern States, which were settled by slave awners who regarded political sovereignty as a natural attribute of their property, the town system was exceptional liecause the general life of this section presented a rural type that found its natural limits in the organisation of the county. !inally in the Middle States, where the two economic forms coexisted, the two corresponding administrative systems liourished side by side. ${ }^{1}$

But the monopoly of administrative power, so persistently and universally maintained by the propertied class, is a fact of still greater importance. Thus it is to be remarlied that when Greece was a Roman province powerful families dominated the provincial diets, and the municipal magistacies were conferred more in accordance with the possessions of the candidates than their individual merits; while in Asia Minor the controlling influence was placed directly in the hands of the rich." It must also be evident, even to the less clearsighted, that matters have not altered much to-day; for the proprietary classes still predominate in all spheres of modern administration, either directly or through their delegates and representatives. True, in several communes and in some provinces the popular element has come to prevail in administrative councils, sometimes even tending toward a kind of local socialism; ${ }^{3}$ but this is generally due to the indolence of the bourgeois class, which does not place much store upon adminis-

'Bryce, loc, cit., ii., pp. 221-25.

${ }^{2}$ Mommsen, Les Provinces romaines, etc., trans., Italian, Rome, 1887 , pp. 261, 267, 325.

${ }^{3}$ Thus, for example, when the communal councit of Plaisance, composed of working men and democrats, in January, 1891, voted 128,000 francs of new taxes, a violent demonst at ion was male against the plan by the rich population of the town. Sec also the facts recounted lyy Laveleye upon the influence of the kiferendum in Basilat aille (Le gonternement dans la democratic, Daris, $189 \mathrm{I}, \mathrm{ii}, \mathrm{p} .158 \mathrm{ff}$.$) . We should also call to$ mind the recent socialist elections in Camaux, the origrinal cause of the famous strike. 
trative power so long as political sovereignty remains in its hands. And rightly too, because the capitalistic monopoly of political power must eventually make a mere mockery of this attempt on the part of a fraction of the labouring class to control the administrative machinery. Thus popular influence in administration is effectually checked in a large number of the American States by a law limiting the amounts the different administrative bodies are allowed to raise by taxation. In the majority of European States, on the contrary, the deliberations of communal and provincial assemblies are (by a law emanating from the dominant bourgeois class) subject to the veto of the executive power which is a creature of the bourgeoisie. This in itself is enough to neutralise the labourer's attempt to lay hold of administrative authority, and all danger to the dominant rights of capital is thus avoided.

Judicial authority has likewise become an appanage of the proprietary class, though it does not always show sufficient ductility to follow all the varying forms of the economic system. Interesting contrasts arise from this fact, one of which we may mention by way of example. The jury system (being the direct exercise of judicial authority by the proprietary class) gave excellent results in classic Greece and Rome, where it was even extended to civil cases. In our day, however, the institution offers a miscrable spectacle of its own impotency, though it has since been confined exclusively to criminal cases. The reason of this is that the capitalistic conditions of ancient society disassociated the proprietor from productive enterprise and urged him to take part in public affairs; while modern economic relations, riveting the capitalist's attention on production, render any conscientious exercise of public functions on his part impossible. Our juries are consequently made up of those who do not possess competency or influence enough to exempt them from the duty. They are thus constituted from the outcasts rather than from the élite of the bourgeoisie. It is, therefore, not to be wondered at that the verdicts rendered are too often ludicrous, and offer melancholy evidence of intellectual degradation and the violation of all law and commonsense. 
The conquest that eventually crowned property politically supreme was of a different nature than those thus far described. It was effected by the proprictors ennobling themselves and raising themselves to the rank of a privileged class, to be distinguished for gencrations to come from the vulgar herd of non-proprietors. This process does not, however, appear to be logically consistent with the political power of wealth; for if sovereignty follows property, it cannot well be attached to the personality of the proprietor, as it would not in this case be free to detach itself from him whose property has been taken away. Wealth being essentially an impersona! phenomenon, to-day belonging to one man and to-morrow passing over to another, the dependence of political sovereignty upon such a factor would imply its independence of all personality whatever, and therefore render the very idea of an inherent political power vested in some man or family altogether absurd. But incompatible as these consequences may at first sight appear with the political sovereignty of property, a closer examination will show us that they are in reality the normal coroliary and final expression of such sovereignty. In fact, those who came into possession of political power by engrossings the revenues naturally hastened to take advantage of this opporitunity to perpetuate their privileged condition by making it henceforth independent of the fluctuations of property. And hy what means could this be effected? Simply by decorating themselves and their children with a special title, and by investing their families with an indelible mark of distinction which would henceforth assure them a share of political power even though their property might be subseguently curtailed or lost. An income could thus be secured by virtuc of their personal dignity, even though no longer to be obtained from property. Thus the' genius of property was thoroughly eculual to the dificult operation of rendering the phenomenon independent of its hase. The political power originally accuired from property was thus prescred, and an income assured even after its property basis had been removed. There is, therefore, an appatrent inversion in the normal relation betwen economic revenue and political sovereignty in these cases of imporerished descendants of the 
noble houses of landed proprietors; for to them political power is undeniably the source of private income. But if we look into the matter more closely we shall see that this inversion in no wise militates against our thesis. In fact, it is one of the best proofs of our proposition, because this same political power which is to-day a source of private income was itself the result of the revenue absorbed by some antecedent proprietor, who made good use of the power that wealth gave him by perpetuating it in his posterity, as such, independently of their economic condition.

Such was the origin of nobility and such the special causes leading to that division of humanity into two social classes - patricians and plebeians, nobles and roturiers, lords and commoners. But however much to the individual advantage of the proprietary class the institution of such a noble order might be, the plan could only be effectively realised when inherent econonic conditions rendered it possible, or perhaps even necessary. When, on the contrary, the economic constitution of socicty offered obstacles to its fulfilment, the project was inexorably condemned. Under certain social phases, inherent economic conditions, indeed, demand the ennoblement of proprietors. During the feudal period, for example, political sovereignty, constituting a personal attribute of the proprietor, could only be effectively exercised when capable of transmisson from father to son and confined to the family as its inalienable heritage. Thus the inherent conditions of feudal society caused a marked division to occur between noble and plebeian families, quite independently of the individual interests of the feudal lords themselves. Now-a-days, however, the conditions are reversed; for, under the normal development of the wage system, economic egoism must be free to follow its own inclinations without being checked by any manner of restraint. Thus the existence of a class of men enjoying power, or even mere privileges, without controlling corresponding revenues, and ruling merely by virtue of heredify and tradition, is inconsistent with the normal course of economic development, tending as it now does toward the simple omnipotence of wealth. Modern economic conditions consequently demanded 
the destruction of the political and social power of name. The nobility, gradually deprived of their former prestige and retaining a mere nominal distinction, found themselves accordingly compelled to renounce all influence in politics and confine their activities to elegant salons; the rendezvous of idleness and ennui.

But even after economic conditions made it no longer possible for power and privilege to inhere in the person of the proprietor, capitalistic property still continued to maintain the privileges and distinctions of the owning class as a group, and finally engendered such a condition of affairs that it became irrational, and even dangerous to extend political power to the non-owning classes. In short, the intellectual capacity necessary to good government was developed among the proprietary classes as their wealth increased, and opportunity was thus afforded of cultivating the higher virtues of the mind. The disfranchised classes, on the other hand, lost intellectual power with their increasing misery and degradation, and relapsed into greater brutishness as the distinction between the rich and the poor became more marked. This mental degradation of the non-owning classes involved political incapacity as well, and made it socially necessary to deprive them of privileges which they could only have exercised in an irrational and brutal manner, involving the entire society in anarchy and ruin. Having engrossed political sovereignty with an exclusively egoistic end in view, property thus created an order of affairs which made it necessary in the interests of civil society for the proprietors to retain their political authority. The political ascendency of the owning classes thus finds its complete justification in the very eondition of affairs which they themselves originally brought about. ${ }^{1}$

Though the facts thus far mentioned seem to offer decisive proof of the dependence of the political upon the economic constitution, other phenomena of no less importance appear to

'Maine (Essay on Populin Goverumcut), and before him Austin, relicd upon the political incapacity of the poor classes to condemn popular government, forgeteing. howerer, that this very incapacity and the degratation that hought it about were simply the natural results of the capitalistic economy. 
contradict the hypothesis. Among the latter we might mention the laws for the protection of labour, which very often lower the profits of capital, and the laws regulating landed property, which limit the rents and privileges of the landlords. Laws such as these are certainly contrary to the interests of those who, according to our theory, compose the State. To solve these apparent contradictions, we have to study with some care a whole series of facts that have not jet been brought to light. 


\section{CHAPTER II.}

TIIE BIPARTITION OF REVENUE AND SOVEREIGNTY.

UNDER the free-land economy the revenue acquired by the producers of capital and the ordinary lahourers presents a character of absolute uniformity, precluding any divergence of interests among the several members of the community. There being hut one form of revenue, acquired in equal proportions by all the co-labourers, the preponderance of one form of income or of one class of producers orer another is absolutely impossible. Consequently legislation or public administration emanates spontaneously from the gencral will and is in no wise dictated by the interests of the majority.

The revenues from capitalistic property are, on the contrary, subdivided into two distinct categories, rent and profits, differing from each other substantially, and even showing dynamic opposition. This partition of the reventies into two fundamental forms occasions a corresponding schism in the dominant class. and introduces the germs of a perpetual division. The revenueholders, though dominated as a class by the common desire of preserving and augmenting their income, are at the same time equally desirous of increasing the special kind of revenue acquired by each group. The former interest draws the members of the proprietary class together in their efforts to clominate and control the subjugated population, hut the latter aim divides them into two hostile camps, each endeavouring to increase its own special income at the expense of the other. Thus while the subjugated class presents a solid and compact front, its nembers being held tonether by the very identity of their condition, the twofold division of the revenues occasions a bipartition of the dominant class; and inasmuch as revenue is the basis of political sovereignty, this economic bipartition 
occasions in its turn a corresponding schism among the holders of political authority, and thus creates two political parties animated by opposing interests. Those who live from rents, being benefited by the natural increase of wealth and population and opposed to productive improvements, represent the Conservative party ; while the Progressive party is made up from those who receive profits and who find every improvement in production to their advantage. ${ }^{1}$

Even when cultivation is limited to the most productive lands, and before land rent is cieveloped, an economic conflict may break out between agriculture and manufacture if one or both of them be monopolised. Under such conditions a natural antagonism arises between agriculture and industry, each striving to increase its protits at the expense of the other, and each eager to claim undue advantages. This economic antagonism engenders a corresponding political conflict, and this explains how the ruling class may come to be divided into an agrarian and an industrial party in countries where the population is sparse and where land rent does not exist. During the carly days of the American Republic and in medireval Europe industry was carried on by free artisans, who were protected, by natural economic conditions or by means of artificial monopolies, from the competition of the agricultural producers, represented by the landed proprietors and serfs. The economic conflict, engendered between these two species of profits by this monopoly, gave rise to a political struggle which dominated the entire life of the times, and occasioned the most interesting phenomena. But now that free competition prevails there is no longer any occasion for such a schism between the holders of agricultural and industrial profits, since they are both dominated by the same interests. Now that rent has assumed its automatic character, the differentiation

${ }^{1}$ The great philosopher Coleridge reeognised this faet, and identified the Conservative party with landed, property and the Liberal party with movable property (see St. Mill, Coleridge, in his Dissertations and Discussions, London, 1875, i., pp. 447-48). Turgot also offered several excellent observations upon this subjeet. Naturally, this statement, though true as a general proposition, cannot always be applied to every particular case. 
of the revenues is based upon the inevitable antagonism between capitalistic profits and land rent.

It is this fundamental division between the two branches of capitalistic revenue that is the cause of the perpetual conflicts between the Conservatists and the Progressists in Italy, between the Opportunists and the Radicals in France, between the Whigs and the Tories in England, between the P'rovinciani and the Portcni in the Argentine Republic, and between the Republicans and the Democrats in the United States. We note, however, a striking difference in this regard between Europe and America. Though established upon economic foundations, the political parties of Europe have other than purely economic ends in view, because the revenues maintaining these parties require a whole series of political, ecclesiastical and military regulations for their proper development. But in America (and the day will come when identical conditions will prevail in the Old World) international questions, religious controversies, and all that sad heritage of strife that a hundred centuries of history have bequeathed to Europe, are happily unknown, and the divergent revenue interests can therefore be perfectly well safeguarded by purely cconomic laws. Consequently, not only the platforms, but also the ends and aims of the American political parties are essentially economic in character. It is a perfectly well-known fact that the Republican party of the United States, which upholds federalism and protection, is composed of the commercial and manufacturing classes; and that the free-trade and States-rights Democratic party recruits its ranks from the class of landed proprietors. The struggle between these two partics is thus essentially economic, since it corresponds exactly to the most important division of their revenues. The conomic character of American political parties is, indeed, so matried that we see them change whenever social conditions or the interests of their memlers are altered in any way. Thus in 1852 the Northern Capitalists belonging to the Republican party passed over into the ranks of the 1)emocratic party without any further ado, hecause the loans they had made to Southern slave owners gave them a deep interest in the landed property 
of the South. ${ }^{1}$ An analogous condition was produced in 1889 when an increase in the duties on raw wool injured the woollen manufacturers, and caused them to go over to the Democratic party. At the time of the presidential election of 1888 a large number of the Republicans who had taken up farms in the west voted for the Democratic candidate, because a Republican victory meant the continuance of protective duties which were especially injurious to the interests of the farming class, forcing them by these indirect taxes to enrich the industrial plutocracy of Pennsylvania and New England.2

Besides this fundamental differentiation of the revenues into rent and profits there is also a further subdivision of the latter into cntrepreneur's wages and the capitalist's interest. A considerable amount of wealth is furthermore taken from rent and profits alike to pay the interest on unproductive capital and the wages of unproductive labour. These sub-species of rcvenue give rise to as many conflicting interests, or economic groups, which sometimes form separate political factions, but more often adhere to one or the other of the two main political parties. Unproductive capital and unproductive labour are of the most importance in this regard and exercise considerable political influence.

As economists know, during certain social phases unproductive capital is necessary to guarantee the existence of capitalistic revenue, and accordingly becomes the object of particular favours on the part of agricultural and industrial property. During such periods it is but natural that the political influence of this form of capital should liliewise be considerably strengthened. And even though it fails to reach this position of political preponderance with the assent of the other revenue factions, unproductive capital may still be able to

1 Cairnes, The Slave Power, London, 1863.

'See Bryce (loc. cit., ii., p. 338 ff.), who is wrong, however, in affirming that the division of partics in America docs not correspond to a class distinction. And when he adds that the division is not along horizontal but along vertical lines, he is only right so far as the American party lines, like those of any civilised country, do not correspond to a contrast between the rich and the poor, but to a distinction between the two kinds of revenue, 
attain political control in spite of them, through the concentration of wealth which draws gigantic fortunes within the sphere of its influence. In ancient Rone, for example, the farmers of the revenues acquircd political supremacy with the augmentation of personal wealth and came to form the privileged equestrian order which dominated the comitia and opposed the patrician land owners. ${ }^{1}$ Mediæval Italy also suffered under the political domination of bank capital in its cruciest form at the hands of the bank of St. George of Genoa, a financial institution which acted under the Republic and determined its actions with the utmost precision. In fact, in all the Italian Republics bankers for a long time exercised an ascendency, which became even greater as the towns needed more money to develop their belligerent policies. And as the bankers kept in constant touch with the sovereign Pontiff, in order to transmit the Peter'spence and the tithes forwarded from foreign countries, the Pope profited by their influcnce to bring the majority of the Italian States to his side. ${ }^{2}$ Some time after this the bankers Fugger of Augsburg, Germany, secured an impregnable position by refusing the exchange of the Genoese banks and concentrating German money in their own hands. They then refused to alluw credit to the ling of France and gave the imperial crown to the lord of the Netherlands. This preference was made because Charles V. pledsed them in return the commerce of Antwerp and other very lfourishing towns, hypothecating in their favour the custom revenues that came in to him from these ports. And how did the bankers aid the emperor in his ambition? By' buying up the votes of the principal electors who trafficlicd in their own consciences according to the most approved laws of supply and demand. These bankers also monopolised the office of receivers in the sale of indulgences to which the Popre had been forced by the financial distress of the time. Hence it happened, as Michelet has already observed, that they were instrumental in bringing two great events to pass that changed

'Hegewisch, Historisches Versuch äber die rönisitün Finunän, Altona, 1804, p. 140.

"Hartwig, Florentiner Gisthichti, 1250.1202, in the Deutsche Zeitsthift fur (ieschichtswissonschaft, 18s9) i. b. 22 It. 
the face of the world: the coronation of Charles V. and the Reformation. Finally in Great Britain the Bank of England was powerful enough on the morrow of the "glorious revolution" to overcome the coalition party of the Jacobins and the small gentry, and to protect the new dynasty, by preventing a change in the ministry that might have compromised its political prestige. $^{1}$

But it is in our day that the political power of unproductive capital is most clearly marked. With the centralisation of wealth and the creation of great banking fortunes the political power of property has assumed a new and more important character. Now-a-days the political monopoly of capital is no longer content to manifest itself through the acts of the legislative body alone, but must also bring pressure to bear upon the executive power as well. This is done by means of alliances and illicit connections between the bank on the one hand and Government finances on the other, and through the latter's necessarily increasing dependence upon the former. By thus subjecting the executive power to its influence, capital gains a means of political domination that is more expeditious and freer from attack, because its activity is now clandestine and out of the range of parliamentary assemblies that are open to the fire of public opinion. Moreover, unproductive capital is itself provided with defences of its own to meet any such attacks. For example, the most typical form of unproductive capital, the public debt, makes it possible for the Government to abstain for some time from levying new taxes, and thus frees it at least temporarily from the control of legislative assemblies. ${ }^{2}$

The present political omnipotence of unproductive capital must, incleed, be clear to every one. And to persuade ourselves of the truth it will not be necessary to recall the conditions prevailing in modern Italy, which offer us only too evident demonstrations of the fact; it is enough if we turn our attention to the social phenomena of free America. American capital, in its menacing proportions,' now exercises clandestine and despotic power over the Government much more effectually

${ }^{1}$ Lecky, England in the Eightcenth Century, i., pp. 199, $249 \mathrm{ff}$.

${ }^{2}$ Adams, Public Debts, Neiw York, 1887, p. 23. 
than European capital is able to do. Agents of the railway companies rule the lobbies of Congress, and in this way impudently bring their irresistible pressure to bear. The American rings, controlled by financial magnates mysteriously omnipresent, are able to impose their capricious demands upon legislative and administrative bodies. ${ }^{1}$

The political influence of unproductive labour is no less important than that exerted by unproductive capital. There are times when unproductive labour gains a considerable share in the revenues, and sometimes, indeed, in capital itself. Un. productive labour's share in the revenues naturally implies its participation in political sovereignty. The political power of unproductive labour is especially marked when it has secured an interest in property, for this allows it to play its natural political part of opposing the dominant form of revenue and courageously restraining its excesses. Thus, for example, during the middle ages the unproductive labourers, represented by the ecclesiastics, acquircd special economic importance, because they were nccessary to guarantec feudal property against any reaction on the part of the labouring class; for this reason the ecclesiastics were not only allowed to participate in the revenues, but were also rewarded by a share in capital itself. The economic independence thus accorded to unproductive labour, allowed it to offer a successful resistance to both the landed and the capitalistic revenues. Hence arose those interesting political struggles between Church and State, or in other words, between ecclesiastic and secular property. Feudal revenue, having already endowed the unproductive labourers very richly in order to guarantee its own existence, now sought to take back the donations it had made; while the unproductive labourers, becoming emboldened by power, continually pretended to fresil concessions. In our day, however, the unproductive

'Bryce, loc. cit., ii., p. 463. Hudson, The Railways and the Republic,

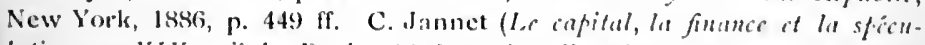
lation an XIXe sicle, Paris, 1392, p. $497 \mathrm{fr}$.) grives us some eloquent data upon the political power of the Rothechilds. Amedeus of Savoy withdrew from his contest for the throne of Spain because he found he was being made the tool of intriguing linancices. 
labour of the ecclesiastics is no longer essential to guarantee capitalistic property, and the economic importance of the clergy has accordingly been reduced to very modest proportions. Not only has all their property been taken away from them, but their share of the revenues has also been greatly diminished. ${ }^{1}$ But a new form of unproductive labour has since arisen out of the ruins of the old, and the class is now-a-days represented by employees, magistrates, lawyers, physicians, journalists, and, in general, by the liberal professions. Their duties, and especially their moral duties, are arranged for the benefit of capital. True, they are no longer rewarded by a share in capital itself, but their participation in its revenues is amply sufficient to compensate them. Of this class of unproductive labourers, sometimes one group prevails and sometimes another. In America, for example, the prevailing group is that of the lower employees, while in France it is the group of higher employees. As a result it is the lower employees that are better paid in America, and the higher employees that are better paid in France, simply because in the former country salaries are determined by the lower employees, and in the latter by the higher. ${ }^{2}$ But whatever be the group of unproductive labourers that comes to prevail in each nation, it always acquires an important political position, allowing it to combat the revenue from property with some degree of success. True, this struggle between unproductive labour and the revenues can never result in the latter's entire destruction, for in this case unproductive labour, which itself lives off the

It is this falling off of ecclesiastical revenues that has driven the Pope to speculate on the Bourse, but his operations have not been successful, and he has been obliged to disburse a million and a half to make up the deficit. To cover his loss he has loaded Father Didon with all manner of attentions, that he may secure a large number of French pilgrims with their customary offerings for St. Peter. But as this source will continue to afford, less and less, the time is sure to come when the Pope will be compelled to accept the obolus that is guaranteed him by law, and thus put an end to the Roman question. If this be the outcome, it will again be economic conditions that finally solve the political problems.

${ }^{2}$ Roscher, Naturiehre der Domokratie, 1890, p. 60. 
revenues, would only exhaust the sources of its own remunerative appointments. Nor can this conflict abolish the office of unproductive labour, which has still to guard the retainers of the revenue from all reaction on the part of those who are excluded from the possession of the soil. But within the limits thus circumscribed by the inherent conditions of the capitalistic economy, this struggle between unproductive labour and the revenues is none the less a constant phenomenon, which, as we shall see later on, exercises considerable influence upon national politics.

Accompanying this qualitative division of the revenues into rent, profits, interest on unproductive capital and the remuneration of unproductive labour, a quantitative differentiation is also to be remarked between large and small holdings. Small undertakings, whether manufacturing or agricultural, find themselves in marked antagonism to large concerns, and associated by community of interests with the labouring class. Thus so long as small holdings can preserve any political influence they continue to engage in a fierce struggle with the dominant plutocracy. We find examples of this in the conflicts between the patricians and plebeians in Rome, between the great and lesser vassals cluring the middle ages, between the lords and gentry in the earlier British Parliaments, between the large and small proprictors during early times in Denmark, and in our day between large and small industrial undertakings. There is, therefore, a double conflict between the different kinds of revenue on the one hand, and between the different degrees of income on the other. And it is worthy of note that the conflict between the two degrees of revenue becomes more accentuated as the struggle betwcen the two species of revenue and their sub-species is less marked. In Rome, for example, where in the absence of a distinctly industrial class there could be no marked division between agricultural and industrial profits, and where the conflict between the large landed estates and unproductive capital did not arise until a later period, the struggle between large and small holdings was correspondingly acute and characterised the entire social development. 
The political power of property naturally becomes greater with the elimination of these mixed forms of revenue which accord a share of political authority to the classes whose interests draw them into community with those who are excluded from ownership entirely. Small proprietors, metayers, and independent artisans finding themselves more in accord with the wage earners than with the great capitalists usually favour the legislative limitation of large estates for the benefit of the proletariat. Capital's political monopoly therefore demands the destruction of this middle class, whose interests are with the labourers though they share in political power. To be strong against the masses, property must be concentrated said Burke. The destruction of the small proprietors is, consequently, an essential condition of the life and development of property, and for this reason after having gained political supremacy the large owners always use their power to ruin the small. It is, indeed, with this end in view that the system of taxation is arranged in all countries where the large owners predominate politically, with a view that is (as has long since been observed) to inevitably ruin the average and smaller holdings.

In the course of social evolution changes occur in the economic energy of the differcnt linds of revenue, and political ascendency consequently oscillates and passes from one form to the other. Thus in ancient Rome economic supremacy at first belonged to the patricians who represented productive capital, agricultural and commercial alike, and to whom loaning at interest and all employment of unproductive capital was forbidden. But the insuperable obstacles that slavery offered to production forced an increasing amount of capital in to speculative enterprises, and therewith transferred the economic and political sceptre to unproductive capital, represented by the publicans. These speculators, however, enriched themselves not so much from Latin capital as from the productive capital of the provinces, by means of exactions laid upon the conquered peoples. The incxhaustible fertility of the Asiatic lands offered a broad field for their rapine and, by enormously increasing their fortunes, secured them a dominant position in the government of the State, in virtue of which they eventually obtained the 
monopoly of judicial power. The unproductive labourers of the period, the clients, were for a long time the paid apologists of their depredations, and Cicero himself, who gave proof of a not very costly patriotism in combating the unproductive capital divided tip among a number of small owners, then engaged in the exploitation of Sicily, had finally to champion these more powerful Asiatic publicans in his oration pro lege Manilia. During the third stage of Roman evolution, however, the increasing agitation of the slaves rendered the work of the clients much more important. The unproductive labourers then became an economic and political power, and the military chiefs whom they elected began to hammer away at speculative capital with redoubled blows. Pompey, though the favourite of the publicans, still held them in checli, Cosar then disciplined them, and Augustus finally crushed them entirely by suppressing their political and judicial function and suhstituting paid functionaries of the Government, the frocuratores. Thus in ancient Rome political supremacy underwent an interesting transition, passing from productive to unproductive capital and ending finally in the triumph of unproductive labour.

Turning our attention from ancient to modern times we see that, in our day also, economic development tends to alter the quantitative relation prevailing between the different forms of revenue. Before accumulation has gone very far, sent maturally predominates over profits, and the land-owning class exercises tyrannical power in the legislative assemblies. But with economic progress and the increase of accumulation several new and partially contradictory influences come into play. If the proprietors of the soil were to malie it impossible for capitalists to subsist by refusing to cede any land, they might maintain their monopoly of political power, for the mere threat would seem enough to put them in control of the industrialists' votes. But inasmuch as the capitalists could still maintain themselves for some time on their accumulated stock, even though the refusal of land on the part of the proprictors prevented them from employing it in productire walys, the landlord's pre-eminence over the capitalist would probably' not go

${ }^{1}$ Deloume, Les manicurs d'argent i Rome, Paris, 1890, p. 400 ff. 
uncontested. It is very true that rent has an upward tendency and that the tendency of profits is to diminish; but it is equally true that the political power of the landlord is limited to his rents, while the capitalist's power is not limited by his profits but by his capital. Even as the capitalist controls his labourers, so (at least when wages are low) does he dispose of their votes, and to a degree that is exactly commensurate with the importance of the capital employed. Thus in the political struggle between real and personal property, it is really rent and capital that find themselves engaged. In the course of cconomic progress, the influence of the landed proprietors undoubtedly appreciates with the increase of rent following the augmentation of population and industrial capital; but this very augmentation of capital multiplies the number of those representing personal property, while the introduction of agricultural machinery leads to a diminution of the rural population at the disposition of the landed proprietors. ${ }^{1}$ The relative power of these two forms of revenue is thus the resultant of two adverse influences. But it is easy to see that their net result is the progressive extension of the capitalist class, and the declining prevalence of proprietors. And this result is only the more accentuated by the prevailing system of renting which removes the agricultural labourers from the authority of the proprietor and places them under the tenant, who by the very nature of his income is in sympathy with the industrial capitalist. ${ }^{2}$ The increasing indebtedness of landed proprietors to unproductive capital also favours this result. Hence the formerly powerful proprietary

${ }^{1}$ We find a remarlsable example of this in England, where the increasing migration of the rural classes to the cities changed the electoral centres and made it necessary to increase the political representation of the towns (Gneist, Self-government in England, 3rd ed., Berlin, 1871, pp. 6264). Industrial centralisation, the product of technical improvements tends to aggravate this result.

2 In 1867 England extended the right of suffrage to tenants and made them independent by instituting the secret ballot. This measure increased the political influence of the tenant class, and one of the first results was an agitation on their part for compensation for landed improvements (Caird, The Landed Interest and the Supply of Food, London, 1880, pp. 7273). 
class is slowly forced to abandon its superior position to the capitalists, who thus gain political powcr. ${ }^{1}$

But profit's political triumph over rent is often cut short by the unexpected intervention of unproductive labour, or unproductive capital. Indeed, these latter forms of revente are very apt to thus offset the political predominance of productive capital by allying themselves with land-rent, which can then continue to dispute the field with growing industrial property. Within comparatively recent times, for instance, Southern Italy was the scene of just such an alliance between unproductive labour and rent. To put it more definitely, the kingdom of the two Sicilies was simply an absolute monarchy founded upon unproductive lahour and land-rent, and for this reason capital and the bourgeoisie were there loaded with all manner of abuses.2 In our day it sometimes happens that the wavering political power of rent mects its Blücher in the intervention of unproductive labour. More frequently, howerer, unproductive labour makes its alliance with profits rather than with rent, while unproductive capital, on the contrary, usually decides to join its forces with rent. This last alliance completely changes the normal equilibrium between the two dominant revenue forms, and definitely determines the political supremacy of rent

${ }^{1}$ The German nobility, secing their privileges of presentation in the upper house disturbed, grasped as a last resort at 1,iebig's theory of the inpoverishment of the soil, and declared that if it was desirable to legally require the restoration of the minerals taken from the soil, it was necessary to confide to them the requisile power and jurisdiction (Fratas, Dic Ackerbunkisin, Leipzig, 1866, p. 143). But naturally this was not enough to retard the political triunph of capital. This viclory has also had its effect upon jurisprudence. Thus for a century in france the lawyers proclained that the rights of the cultivator were superior lo lhose of the manufacturer, and that, for this reason, water rights helonged to the riparian proprictors, inasmuch as the manufaclurers could substitute some other force for water-power, whereas the agriculturists could not do without the water necessary for irrigation. These considerations rught to carry still more weight now-a days sinee the introduction of ste:1m, hut they have nevertheless fost all the authority they ouce had, because manufacturing industry his since hecome supreme.

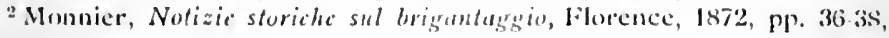
104.106 . 
over profits. The triumph obtained in this way means, however, a victory for unproductive capital. It is, therefore, natural that unproductive capital is to-day preponderant in the countries where it has succeeded in effecting an alliance with ground-rent and, thanks to this alliance, dominates the rival revenues. ${ }^{1}$ Thus while in England and in Germany the Government is able to maintain its control over the banks and railway companies and holds them within bounds, in modern Italy, on the contrary, the banks and the railway companies tyrannise over the governmental authorities, who are there powerless to restrain speculation within proper limits. This contrast exists bccause productive capital is still powerful enough in England to defeat the efforts of unproductive capital in spite of the support the latter obtains from rent; and because in Germany rent is able to cope with profits singlehanded without the aid of unproductive capital, which is thus left isolated and powerless. But in Italy the situation is very different. In order to be able to contend with profits in the arena of politics, rent had there to involse the alliance of unproductive capital, which thus became an essential auxiliary of landed property, and, thanks to its support, obtained important concessions at the expense of productive property. ${ }^{2}$

The alliances thus formed between the revenue from unproductive capital and land-rent on the one hand, and between the revenue from productive capital and unproductive labour on

${ }^{1}$ When unproductive capital holds its power uncontested in politics, it itself is apt to become divided. Thus in France, follcwing the favours bestowed on the Rothschilds by the Government in 1847, a large party broke away from the high bank, and passed over to the opposition forming the centrc left (Capefiguc, Histoire des grandes opérations financieres, Paris, 1858, ii., p. 211.)

2 Italian politico-economics, characterised so largely by favours granted to the landed proprietors and bankers, really rests upon this coalition of rent and unproductive capital. . The confusion that prevails in the organisation of our banking system, and the impotence of our laws concerring bank circulation, will never ccase until some clever minister succeeds in uniting productive capital with the people in a compact alliance against the bankcrs and agricultural proprietors, or at least succeeds in breaking up the alliance between the latter 
the other, render the original contrast between real and personal property of continually less importance with the progress of economic development. Noreover, with the increasing mobilisation of property, real and personal estates are brought into closer accord, thus minimising the chance of conflict between the two. At the same time, the inevitable schism between productive and unproductive capital, as it becomes more marked, tends to form the economic platform of political strife and party division.

Such in broad outlines are the relative positions occupied by the different kinds of revente in the political struggle, and such are the complicated relations that prevail among them. Now the quantitative relations between the different linds of revenue likewise exert political influences that are worthy of remark.

Whenever rents prevail in one part of a State and profits in another, the confliet that breaks out between the two assumes the character of a territorial strugsile, and sectional politics thus arise as the corollary and natural product of the underlying economic sectionalism. This is especially true in the wage economy, or, more properly, under the representative system of government which is its necessary consequence. This system of government allows two sections equally well populated to send the same number of representatives to Parliament, though the wealth of each may be very different, though large incomes may prevail in one and small in the other, and though the kind of revenue acquired in one section may be more powerful than that ohtaned in the other. This allows the smaller revenues to control as many votes as the large and thus continue to struggle successfully. For this reason those who woukl have political power exactly commensurate with riches, do not hesitate to propose that the several provinces of the State elect their representatives not according to their population but according to their wealth; that England, for example, holding eight-tenths of the wealth of the Linted lingemen, should also elect eighttentlis of the total number of representatises in Pandiament.

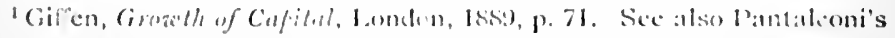

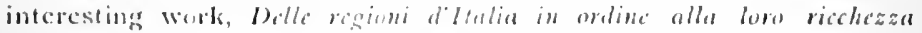
(Ciomale degli Economisti Jan., 1s\$) 
But this proposition is evidently unrealisable, as it is in contradiction with the principle of political equality that constitutes the organic law of the wage system. It shows, however, to what extreme conscquences the economic antecedents of political sovereignty may lead. We should hasten to remark that the equal representation of quantitatively different revenues does not in the least disturb the dependence of political power upon property, because even in the poorer provinces it is property alone that counts, and the equal authority of quantitatively different revenues in no way contradicts the capitalistic basis of sovereignty.

Instances of sectional politics growing out of economic sectionalism are to be found in all countries. In Italy, for example, land-rent prevails in the central provinces and capital in the north. The former provinces, accordingly, demand import duties on grain and the latter import duties on manufactured products. A sectional conflict has thus arisen which is often compromised for the time by an alliance ratified between the two at the consumer's expense. And the same is true of Austria, where different forms of revenues prevail in the different provinces. There the principal contest occurs between agricultural and industrial proprietors, but conflicts are also of frequent occurrence among the different industrial classes. Thus, for example, the moment the manufacturers of spinning machinery obtained protective rights, the owners of spinning mills considered themselves injured and demanded import duties on yarns, etc. In these bitter sectional disputes lies the strength of the Austrian monarchy, for it is thus enabled to rule more easily over a population whose economic interests are divided.

It is upon the manner of appropriating and exercising poitical power that these quantitative relations between the different kinds of income really exert their greatest influence. Indeed, when one of the two fundamental forms of revenue is considerably smaller than the other, and has not yet produced a separate class of non-labouring proprietors, it remains practically excluded from political control, which is then monopolised by the holders of the dominant income. Wherever, for instance, the capitalist 
class is not yet developed, and manufacture is carried on by independent artisans, or practised by the agriculturists as a subsidiary industry, land-rent monopolises political power. Such is the case in India, where the zemindars, or proprietors of the soil, are also the representatives of social authority.

This fact has a decisive effect upon the form of government, for whenever one form of revenue predominates and political sovereignty is thus confided to a single class, all discussion and every kind of opposition is eliminated from the government of the State, and the ruling class forms a compact body, which disposes of public affairs at its will. Under such conditions the form of government is necessarily aristocratic. But if the class retaining the revenue be very numerous, it usually finds itself obliged to delegate political power to one man in order to bring promptitude and force into the administrative system. Thus the absolute monarchy is the normal result of the prevalence of a single form of revenue and its division among a number of participants. This form of government rests neither upon the divine right of kings nor upon the meckness of the multitude; it is simply the product of the interests of the economically dominant class, and lasts just so long as it continues to satisfy such class exigencies. Even under the most despotic and tyrannical rigime, the sovereign is only maintained at the good-will of the class that possesses economic power. This class lends him its entire support as long ats his acts as sovereign satisfy its demands and guarantee its revenues more completely than could be done under an aristocsatic government; but it does not hesitate to overthrow him the moment his actions become in any way hostile to its interests or he himself fail to fulfil the function imposed upon him. If we follow the course of Asiatic monarchies, for example, we find they are the result of the predominance of a single resenue form. They continue to persist, in spite of the most barbarous excesses, so long as they are not bostile to the holders of this revenue, and they crumble away, but without in the least altering the conomic system, as soon as the monarchs place themselves in opposition to the interests of the proprictary class.

The sovereign power thus delegated to one man, that the 
class may be more effectually guaranteed in its authority, is greater when the delegating class is numerically large and when the opposing forces are correspondingly powerful. The dominant class limits its delegated sovereignty when its existence is assured, but willingly accords more authority when the opposing factors become numerous and powerful, or, in other words, as the rival revenue becomes stronger and more compact. Thus, during the feudal period, royal authority was reduced to a mere form so long as no industrial class existed; but the growth of industrialism marked a corresponding increase in monarchical authority, because the feudatories then found themselves compelled to confer absolute power upon a single head. 1 This delegation of authority had an unexpected and very curious result. The monarchs, to whom absolute power had been given in order to defend the feudatories from the towns, eventually broke away from their former masters, hoping thus to free themselves from the tyranny of the nobility and limit their privileges. It thus happened that the nobles, though they remained the dominant class, were dispossessed of their absolute power by the very sovereigns upon whom in their own interests they had originally conferred the authority.

Striking proof of these assertions is to be found in the political history of Russia as outlined in Tchitcherin's important work upon national representation. In Russia, too, a struggle broke out before the fifteenth century between the feudatories and the towns. But the political contest in Russia was distinguished from the similar contests occurring in Western Europe by the fact that neither noblemen, seris nor townsmen possessed permanent abodes, but led a semi-nomadic life, moving from one region to another. Even during the fifteenth century "the boyars and vassals were not established upon

${ }^{1}$ Warnkönig and Stein (loc. cit., iii., p. 39) are therefore wrong in thinking that the falling off of royal authority during the middle ages was due to the progressive diminution of the royal demesne, resulting from the constant donations of land to the feudal lords. This opinion is, indeed, controverted by the suecessive additions to the power of the monarch at a time when the royal demesne was reduced to almost nothing. 
their estates like feudal lords, but acquired their demesne lands as nomad mercenaries"; while the towns themselves were but accidental conglomerations of citizens living in provisional encampments composed of transportable dwellings. Thus the struggle between town and country was fought out upon varying ground. This gave a peculiar and striking character to the contest, and, in fact, to the entire Russian system of fiefs and communes. By reason of the chaotic character of these precarious social aggregations, the political constitution was anarchical, and even in the few towns, like Novgorod, that were more stably established and better able to resist the encroachments of the Muscovite princes, there was no permanent political organisation, but only an unstable system of self-government.

The dispersive tendency that thus dissipated Russia's powers and checked her development required an heroic remedy. This came in the form of the Tartar domination, which substituted a rigid immobility for the variableness that had thus far prevailed. The new rule forbade the nobles from going beyond the limits of their domains, and thus made them seris of the empire. Vassals and serfs were also forbidden to quit the estates of their lords, and the townsmen were not allowed to leave their cities. A great chain was thus stretched across Russia, and for the first time in history an entire population was hound to the soil. Those who resented this universal serfdom nost bitterly were nalurally the nobles, who found themselves suddenly deprived of their original independence. They, therefore, formed a coalition among themselves against their new masters, and sought to regain their lost power during the minority of lvan the Great. The central Government accordingly looked for support in the towns, which were forthwith organised more effectually and given an autonomous administration, though at the same time loaded with heavy taxes. It was thus with the aid of the communes that the Russian monarchs were enabled to overcome the nobility and transform their independent and bellicose boyars into obsequious and ceremonious courtiers. But the moment this transformation was effected, the Crars, finding the support of the communes no fonger necessary, once 
more accorded their preference to the nobles, who were the natural supporters of the Crown, and for a long time the Russian Government depended for its support upon the nobility. Thus, in spite of its original elements, Russian political history will be found to offer a perfect analogy with that of Europe. In both places feudal anarchy was suppressed by absolute monarchy, and after having relied upon the communes to vanquish the nobility, the monarchs in both cases abandoned the bourgeoisie after victory was assured to malke common cause with the aristocracy. ${ }^{1}$

When two forms of revenue exist independently of one another, but one is less developed than the other, the struggle between the two kinds of property so represented is purely nominal, for the more important revenue really predominates in politics, leaving the minor revenue but an apparent share in power. And just as the prevalence of one revenue form constitutes the economic basis of despotism, so this pre-eminence of one class of revenues over another engenders either an aristocracy or a monarchy concealed behind more or less democratic appearances. In ancient Rome, for example, the plebeians, who constituted the weaker economic class, obtained but a show of political power through their tribunes of the people. In like manner, during the middle ages the economically inferior bourgeois class was granted but a nominal participation in the assembly of the estates. Under the modern wage system also the prevalence of one type of revenue has given rise to an absolute monarchy but thinly disguised behind parliamentary forms; as in modern Austria, for instance, where profits are confused with wages and have not as yet assumed definite form on account of the prevalence of the metayer system and small undertakings; and in Germany, too, where capital is a growth of recent times and yet already discredited on account of its lamentable excesses. In both cases the landed proprietors still predominate both economically and politically, and, as a result, there is but a nominal parliamentary system in which the minor revenue only exerts an apparent influence, and

${ }^{1}$ Tchitcherin, $O$ narodnomi predstawitelistwo, Moscow, 1866, pp. 357. $358,360$. 
where the dominant revenue rules through its delegate the sovereign.

One of the most remarkable means that the dominant revenue employs under the wage economy to exclude its rival from active power is the division of Parliament into two houses. This plan makes it possible to confine the activity of the minor revenue to the legislative house that is deprived of all political influence. Thus, if we were justified in saying that the institution of the wage economy gave rise to the parliamentary system, we may now affirm that it is the division of this revenue into two unequal sub-species that has occasioned the division of Parliament into two houses. The comparative constitutional history of England and Scotland affords striking instances of this effect of the bipartition of the revenues. In commercial England the bourgeoisie had already acquired abundant wealth before this class had got beyond its nascent state in pastoral and agricultural Scotland. In England, moreover, the statute of Quia emptores was in force, which allowed any one purchasing an estate from a vassal of the Crown to become in his turn a vassal with the right of entering Parliament. This allowed all commoners who bought up the estates of impoverished nobles to participate in political sovereignty. But there were no provisions of this kind in Scotland, and as political power in this kingdom was practically in the possession of one class, Parliament consisted of a single house up to the time of the ultimate union with England. In the latter country, however, the competition of two classes soon occasioned a division of Parliament into two branches, in one of which, the House of Lords, landed property reigned supreme, while in the lower house personal property maintained at least a partial sway. ${ }^{1}$ Now in so far as this division of Parliament into two houses is the result of the bipartition of the revenues, and in so far as the representatives of rent ${ }^{2}$ prevail in one branch,

${ }^{1}$ See upon this subject Dalrymple, An Essay' tozeard the General History of Feudal Property, London, 1759, pp. 267-75.

${ }^{2}$ Unproductive capital, land-rent's natural ally, often takes a place by its side in the upper house. Cases of this kind are to be found in the House of Lords, in the French Senate during the Second Empire, and in the Austrian Herren haus ( $f f$. Hock, Offentliche Abgabch, etc., p. 232). 
and the representatives of profits in the other, the coexistence of the two houses is after all purely nominal, for the house representing the predominant revenue really exercises absolute sovereignty, leaving the other house with purely nominal functions. Thus so long as land-rent prevailed in England the House of Commons was barely tolerated by the House of Lords; but as soon as profits gained the upper hand the House of Lords was sradually reduced to the position of a decorative element in the political system. ${ }^{1}$ Such was also the case in France under the Restoration. The Chamber of Deputies, composed of representatives of landed property, was there outvoted by the Chamber of Peers, dominated by the great bankers. ${ }^{2}$ This division of Parliament into two houses is only really effective when the dominant revenue possesses a majority in both houses. Instead of the two-house system corresponding to the division of the revenue, it then constitutes an administrative mechanism, calculated to introduce a spirit of reflection and temperance into the deliberations of the dominant class.

When the two kinds of revenue attain a certain equilibrium, the political contest between them reaches its fulness and becomes decisive. It is then that the democratic constitution under which this battle is fought out becomes finally perfected. If the two classes of revenue are equally powerful a political balance is struck between the two parties, and State inaction and governmental impotence inevitably result. The only way to breali this political deadlock is to establish an absolute government and replace the antagonistic and poweriess activities of the dominant factions by a personal direction of affairs. But when, on the contrary, the equilibrium between the two revenues is unstable, and when each in turn outweighs the other, the contest between the two factions then engrosses the

1 John Stuart Mill, Representative Government, p. 315. Sometimes, however, as we have already seen (chap. i.), the division of Parliament is intended to exclude the working men from political influence.

${ }^{2}$ Louis Blanc in his Histoire de dix ans paints a vivid picture of the struggles that took place between landed and personal property in the French Parliament during the Restoration. See also Calmon, Histoire parlementaire des finances de la Restuuration, Paris, 1868, and Georges, La dette publique, Paris, 1884, pp. 223-24. 
entire political field, and leaves the monarchy, if it continue to exist, but nominal power. ${ }^{\text {Th }}$ Thus when the English bourgeoisie reached a plane of perfect political equality with the landed aristocracy, and the two well-balanced parties thus formed mutually offset each other without either one gaining the superiority, Henry VIII. reigned supreme, the most absolute monarch that has ever mounted the British throne. But as soon as the bourgeoisie gained the upper hand and succeeded to power, the contest hetween the two political factions was again given free ficld, and the function of the monarchy was therewith limited. We find Charles I., then upon the throne, the weakest monarch England has ever had.

We should add in conclusion that the contest occurring between these two revenue forms, after they have attained their complete development, is both the consequence and the cause of the power of the reigning class. The consiquence, because it is only when the dominant class is perfectly assured of the integrity of its revenues and guaranteed against attack from the non-proprietors that it can afford to indulge in such family quarrels. But the moment the revenues are threatened, the two classes cease their struggles at once and unite against the common enemy. ${ }^{2}$ The cause, since this struggle betwcen

'Two other influences should be mentioned which render absolute government impossible upon the bougeois accession to power. One of these, already mentioned by Macaulay, is that with the increase of capitalistic wealth violent revolutions always work too much injury to the dominant class. It is, therefore, less disposed to resist the usurpations of the monarch by open revolt, and prefers rather to prevent them by constitutional incisures. The other influence, mentioned by Dufresine St. Leon, is that the system of public debts makes it necessiry to have a political constitution that will limit the power of the sovereign, for without this there would be no guarantec to furnish the ereditors of the State.

${ }^{2}$ During the carly days of hourgeois power in England a close alliance was formed hetween the capitalists and landed proprictors, simply becaluse the bourgeoisie felt it s: If hut poorly defended agaunst possible aggressions on the part of the proletariat. And in Austria, too, the struggle between the aristocracy and the plutneracy suddenly ceased in 1848 at the first sound of popular uprisings, and the two adverse factions were suddenly reconcilcd to march together against their common 
its two factions exercises the powers of the dominant group and keeps them supple and active, while unity and accord among its nembers sterilizes the energies of the proprietary class. This is seen most clearly when we compare the degeneracy of those who rule without opposition with the longer and more glorious lives of those who, while maintaining their power, still keep up a ferment of war and dissension in their ranks. ${ }^{1}$

We see thus that the transition from one form of government to another is in no wise due to a change in the structure of property. Liberty is, indeed, ancient, but-contrary to the advice of Mme. de Stael-despotism is equally so. At different epochs and under the most divergent systems of property, we come indifferently upon political liberty and the most absolute despotism, and this in itself is sufficient to convince us that we have not to look to the structure of the property system for the cause of more or less freedom in government. The diversity is due to the manner in which the revenues are divided, whatever be their nature. Whenever the revenues are divided into two sub-species, and each has acquired sufficient-development to successfully compete with the other for political supremacy, struggle becomes a necessary condition of social life. The governmental system must, therefore, be such as to allow the contest to proceed most freely ; that is to say, it must necessarily be democratic in character. But when, on the contrary, only one kind of revenue exists, or when one alone maintains uncontested supremacy in the politico-economic system, supremacy belongs to the holders of this revenue, and the form of government is necessarily aristrocratic. When, however, the members of this class are numerous and consequently in no position to exercise their power directly with any degree of success, they find themselves obliged (and this is especially

enemy (Marlo, Weltockonomie, Tübingen, 1885, i., p. 406). Every day, in fack, we see sudden coalitions of this kind betwcen the opposite factions of the dominant class whenever any menace to property appears on the horizon.

${ }^{1}$ Note the profound observations of Machiavelli, Discorst sulla prima Deca di Tito Livio, Liv. i., ch. iv: 
necessary when the rival revenue shows strength) to delegate their sovereignty to one man, and monarchy becomes ac. cordingly the normal policical form. Thus the bipartition of the revenues determines a democratic government, and unity of the revenues occasions an aristrocmatic government if the revenues be held by a small number of proprietors, and an absolute monarchy if they be divided among a large number.

After these preliminary considerations it is easy to infer the form of government toward which socicty in its ascending phase is inevitably tending. The concentration of wealth (which is the normal result of dynamic conomies) increases the cohesion between the holders of political authority, and thus strengthens the power of the oligarchy. But, parallel with this augmentation in the political powcr of the proprictors, goes as a natural consequence a diminution in the power of the central government; for as the division of wealth among a large number of owners compelled then to delegate their power cither to one man or to a small group of men in order to assure a sufficiently encrgetic exercise of authority, so, inversely, the concentration of wealth in the hands of the few does away with the necessity of such a delegation of power, and personal government becomes therewith no longer an indispensable condition to vigorous collective action. The centralisation of wealth consequently tends to wealien the power of government.

Before attempting to support the truth of these assertions with further proof, let us first avoid a possible misunderstanding. lirom the very fact that the form of government is determined not by the different historical kinds of revenue lut by the manner in which they are dirided, it follows that there is no necessity for a nation to make an experiment with every form of government during the course of its history. A country may, indeed, preserve an absolutely invarialle form of government, even though changes occur in the structure of its revenues, provided that the division of the revenues remains the same. We need not be surprised, therefore, to lind countries passing through a rapid economic evolution and still retaining 
perfect immobility of political structure. Nor is it surprising that some countries have never passed beyond the stage of the absolute monarchy, while others have never known anything else but democracy. The United States furnishes a remarkable example of this. The persistence of the American democracy is due to the simple fact that capitalistic revenue, though it has undergone numerous changes in form and substance, has not yet exhibited that special division that makes for tyranny. This latter form is only produced when the dominant revenue is divided among a number of holders, and over against it stands a rival revenue, subjugated, but still quarrelsome and importune. Now such conditions have never existed in the United States, for during the first phase of their development landed property maintained an uncontested superiority, and industry exerted but an imperceptible influence upon economic and political life. And as the absence of capitalistic exploitation with its concomitant conflicts precluded the necessity of a strong government, it was naturally a democratic régime that was established. Then with the development of the capitalistic economy, industry took a sudden start, bringing it soon on a level with its rival. The balance that was thus struck between the two revenues resulted in the maintenance of the democratic constitution. Thus the United States passed from the omnipotence of one kind of revenue to an equality of power between two rival forms, without stopping for any appreciable time upon the intermediate stage where the prevalence of one kind of revenue is continually disturbed by the restless revolt of another. In short, the rapidity of American development suppressed that economic phase which necessarily determines absolute power; and for this reason the democratic form of government has remained intact in the American republic, despite the continual modifications that have occurred in its economic structure. But beyond this exceptional case, economic development usually occasions a different division of the revenues in its several phases, and corresponding thereto there generally follows a marked change in governmental forms.

Well-known facts demonstrate the truth of these statements. During the epoch when, wealth was concentrated in the hands 
of the patricians, Rome lived under an aristocratic government ${ }^{1}$ but with the augmentation of personal property in the hands of the plebeians, the power of the publicans and small propirietors increased, and, as the conflict between them and the optimates became more marked, the government was transformed into a democracy. Finally when the disappearance of middle-class fortunes left only the few opulents to strugggle with the body of clients and freed men (who shared indirectly in property), victory went to the latter and the empire was established. In the Greek cities, likewise, the triumph of the people necessarily resulted in the tyranny. In the medieval cities also the well-to-do class predominated at the outset and instituted a pure aristocracy. And as their economic power was long maintained, the aristocratic system proved equally enduring. Of this we have a classic example in the Republic of Venice. An aristocracy was there produced by the concentration of commercial capital in the hands of the few, and owing to its tendency toward progressive accumulation this form of capital succeeded for centuries in maintaining its political and economic supremacy. In Geneva the goverument was also aristocratic, though another form of movable capital, bank capital, there prevailed. With the falling off of this revenue, however, the government took on more and more democratic forms. In other medieval towns, less favourably situated for the growth of commercial and banking capital, independent artisans came to predominate, and after then the common people. The democracy then emerged from the conflict between the commoners and the aristocrats, and the victory of the former ultimately occasioned the principality. ${ }^{2}$

${ }^{1}$ The primitive Roman monarchy was essentially aristocratic in character. Servius Tullius, because he granted large stretches of land to the plebeians, was overthrown by the patricians, who elected Tarquin in his place. He in turn wats removed from the throne because he established two pleheian colonies on the land taken from the Volscians.

"When Gautier de Bricnne beerme tyrant in Florence the conmonn people hailed the event with joy. But after the duke was driven forth popular control was still more complete. "Sce," said Villani, "what becomes of the government of a town when it hats artisans, day-labourers and idiots for its lords" (Crunica, anno 1344). 
But the most strilking, and also the most recent, example of this phenomenon is to be found in the rapid succession of political forms that have followed one upon another in contemporary France. In 1815 the great landed properties predominated in the economic, and therefore also in the political world of France. The Legitimist party made up from this class accordingly established an essentially aristocratic government in the Bourbon monarchy. But economic development brought with it a colossal incrcase of capitalistic wealth, and the bankers and industrialists with their enormous fortunes then coalesced into a powerful party which raised the Orleans to the throne. ${ }^{1}$ Under the July Monarchy an issue was drawn between landed and industrial property, and this occasioned the democratic or parliamentary system. This rêgime was but short-lived, however, for the contests between these two fundamental species of revenue and their corresponding political systems were soon after cut short by two memorable events: the revolution of 1848 and the re-establishment of the empire. The active part taken by the people in the former event, and the force they employed in its execution, caused the two great revenue factions to cease their quarrelling and unite against their common foe. Hence in the National Assembly of 1849-51 the great land owners or Legitimists united with the industrialists or Orleanists in forming the party of order, which led a violent reaction against the proletariat. But even after the reasons leading to this alliance (that was after all but transitory) has disappeared, another important phenomenon entered in to make the reestablishment of a democratic government out of the question. Side by side with landed and industrial property there existed in France a third important factor consisting of a large population of small proprietors, whose wealth had steadily increased during the period of commercial prosperity culminating in 1850. As the political power of these small proprietors increased with their economic well-being, small holdings were bound in time

${ }^{1}$ The same events occurred in Austria in 1848. The capitalist class then opposed the Metternich ministry, and, after having driven it from power, substituted a more libcral government in its place (Marlo, i., p. 403). 
to prevail over both landed property and capital. Now this conquest of political power at the hands of several million of these small proprietors could evidently give rise to but one form of government, since the very division of the dominant revenue among this immense number of holders made a direct exercise of political power on their part utterly out of the question, and compelled them (especially as there were other forms of revenue that were hostile to their aims) to clelegate their authority to one man, in order to maintain order and defend their property. Hence the economic necessity of the Second Empire, which rested upon the support of the small estates that has so long been the rule in France. But the economic founclations of this absolute monarchy were soon to be undermined. Personal capital through its exactions, landed property through its encroachments, and the State with its taxes acted as three powerful levers to accomplish the ruin of the small proprietors and reduce them to the position of wage earners. Upon the decline of the small estates whose ephemeral power occasioned the empire, the foundations of this political system were shaken, and the superstructure accordingly fell. Opportunity was thus offered to re-establish a democratic reinime which allowed more room for the contest between the two principal forms of revenue.

In what has preceded we have followed the threefold division of governmental forms - monarchy, aristocracy and democracybecause this is the classification habitually adopted by writers on public law. But from our analysis it is evident that these distinctions correspond but imperfectly to the real nature of the political constitution. In fact, it is a mere illusion to regard our modern political rigime as democratic. Our theory of the economic constitution of the State shows us that there are but two fundamental political forms-the democracy and the oligarchy. The forner can only exist when all are proprietors; for the moment an expropriated class cnters into the composition of socicty, the democratic form is irresocably. hanished, and oligarchy, or the rule of the proprictary elass, talies its place. We find this demoratic rigime most completely developed in the primitive community, where all were proprietors and all took part in civil government. We 
also come upon fragmentary and sporadic examples of the democracy in the medieval towns, where a population composed of artisans and apprentices participated without distinction in the government. But intestine feuds soon led to the rule of the rich and the gradual impoverishment of the many, who were ultimately reduced to the position of wage earners. And this gave rise to political absolutism. Beyond these two examples, every political constitution that has thus far been framed, whatever its outer form, has been in essence oligarchical. Such was the government of the ancient cities in which only freemen participated. The alsolute monarchies were oligarchical in character and so also are our modern republics and constitutional monarchies. The ancient republics were oligarchies because the slaves were excluded from power. The absolute monarchies were oligarchies because the sovereign could not have maintained his power without the support of the proprietary classes. Our republics and modern monarchies are likewise oligarchies hecause they are ruled by the propertied classes alone. We do not wish to say, however, that these various forms of oligarchy contributed in the same degree to the public well-being. On the contrary, there can be no manner of doubt that the transition from the individual sovereignty of the proprietor to the collective sovereignty of property has brought with it a marked amelioration in the condition of the subjugated classes. Individual sovereignty gave arbitrary power to the proprietor, who could abuse his political authority for the satisfaction of his caprices; but collective sovereignty renders the exercise of such political authority more prudent and regular and confines it within limits that are defined in the interests of the entire class. We should also note in the same connection that parliamentary government allows social legislation which is not strictly in accordance with the economic intercsts of the ruling class. And this is possible for three reasons: first, because the moral currents generated from the contact of men in assembly of themselves excite generous outbursts and altruistic enthusiams; secondly, because the very publicity and solemnity of such gatherings preclude the overt manifestation of that economic egoism which shows 
itself so boldly in the secret processes of private enterprise ${ }^{1}$ and finally because the struggle that is let loose under the parliamentary régime renders regulations in favour of the working classes especially necessary. This last is, indeed, one of the most important results that flow from the bipartition of the revenues, and must now arrest our attention.

We have learned from our inquiries that parliaments simply represent the large owners and the classes that this narrow oligarchy deems worthy to share in political power. But we have also noted the natural tendency of an aristocratic body of this kind to split up into two partics; one in possession of active power, and the other endeavouring with the aid of public opinion to oust its rival and gain the supremacy, without however sacrificing its aristocratic privileges in the attempt. The result is that an opposition aristocratic party cnters the political field, which coquets with popular principles to gain the support of the people. ${ }^{2}$ In the struggle thus engendered between the two factions of the income-holding class, it may happen that one or the other, or perhaps both of the two parties, courts an alliance with the disenfranchised class in order to overcome its rival. Thus the capitalist class, indignant at the usurpations of the landlords, and jealous of the political preponderance of the landed proprietors, may excite the agricultural labourers to revolt ; or the proprietors, in their turn, may stir up the working classes against the abuses of capital. We have typical examples of such phenomena in the parliamentary history of England during the period following the corn law legislation. At this time Parliament was composed almost exclusively of landed proprietors. "What can the land owners not ohtain if they remain in accord?" asked a writer of this period. "The old nobility still constitutes an immense majority in the House of

${ }^{1}$ This is a singular application of Hegelian logic to politics. Assem. blies made up of men, who are ruled entirely hy egristic standards, may nevertheless reach altruistic conclusions. "Fieri enim potest ut multi, quorum unusquisque vir non bonus est, tamen congregati ct congressi paucis illis sint meliores, non ut singuli, sed uti universi" (Aristoteles, Politicormu, 1281, iii., $11 \mathrm{C}$ ).

${ }^{2}$ See the remarks of James Mill, ciled by Jolun Sluart Mill (Mimoires, Paris, 1875, p. 89). 
Lords, and in the House of Commons the landed gentry form a phalanx which no ministry nor opposing influence can possibly resist." 1 This Parliament of land owners was the author of a host of invidious acts in the interests of landed property. It authorised the trust estate, it sanctioned the inalienability of lands, etc., ${ }^{2}$ and it levied protective duties upon imported grains, thus raising the price of food stuffs and increasing groundrents. $^{3}$ The capitalists could only partly compensate themselves for the resulting rise in wages by enforcing harder and more prolonged labour from their working men by employing women and children in their factories, and by the introduction of machinery. The industrialists accordingly rebelled against these provisions restricting free trade, and began their celebrated agitation against the corn laws by exciting the people to revolt against the exactions of the landed proprietors. In order to meet these pretensions of the capitalist class and offset its influence, the land owners then began to attribute the misery of the masses to industrial exploitation and to lend their support to the latter's agitation for a reduction of hours and for a limitation of the labour of women and children. Every year in the House of Commons a manufacturer, Villiers, proposed the abolition of the duty on corn, and a land owner, Lord Ashley, pleaded for factory legislation. ${ }^{4}$ This parliamentary struggle between rent and profit really resulted to the advantage of the

${ }^{1}$ Sir James Graham, Corn and Currency, 3rd ed., London, 1827, pp. 6 and 7.

${ }^{2}$ The landed proprietors long preserved their numerical superiority in the English Parliament. This explains how scventy-three years after Pitt's Legacy Act instituted laws of succession for movable property real property still remained exempt (Brodrick, English Land and English Landlords, London, 1881, p. 250). The prepondcrance of landed proprietors in the House of Commons determined legislation in favour of real property (Bagehot, loc. cit., p. 239 ff. Cf. Narlo, loc. cit., i., pp. 384-85).

${ }^{3}$ The same phenomena were reproduced in France. During the feudal period landed property showed itself favcurably disposed toward the free exportation of cercals, but, on becoming converted into bourgeois property, it raised a great outcry and finally obtained high protective duties (1818).

"In France the most encrgetic advoeate of laws limiting the labour of children was Baron Dupin, the celcorated ehampion of the Restoration. 
labouring classes, who thereby secured a reduction in the cost of living and a shortening of the hours of labour. Indeed, the lot of the labouring man would have been still further ameliorated had not the landed aristocrats instinctively recognised the tie that bound them to the industrialists, and foreseen the injuries that must have resulted from a too serious humiliation of the capitalist class. They accordingly paused in their good work, and left child labour beyond the pale of their philanthropy.

Thus the existence of laws and institutions tending to limit the revenues is in no contradiction to the dependence of the political constitution on property. It is simply the result of the division of the revenues into two parts whose ends are opposed, and whose owners are consequently dominated by antagonistic interests. This schism naturally engenders a struggle between the holders of the two forms of revenue, and from the resulting clash of interests the labourers obtain appreciable advantage. The division of the revenues into rent and profits and the antagonism arising between them, therefore, fulfil a great social function by constraining the holders of one kind of revenue to seek an alliance with the people against the holders of the other, and by forcing both classes of revenue holders to consent to legislation favouring the lot of the labourer. Thus after having won their initial cause against the landed proprietors and abolished protective duties, the English capitalists began their decisive struggle against real property by calling for restrictive legislation upon rent rates and upon the legal term of leases. And to the present day they continue to combat the exactions of the owners of coal mines and uphold the cause of their lahourers. The proprietors, on their side, denounce the abuses attendant on the emission of bank notes and oppose the joint stock companies, demanding restrictive legislation and stricter surveillance for both. In their own behalf and against the interests of the capitalists, the landlords also secured the abolition of imprisonment for debt, and continued their campaign against the exploitation of the factory labourers. This double movement resulted in the land laws of England and Ireland, in the laws 
restricting bank issues, and in labour legislation, ${ }^{1}$ provisions that are all, directly or indirectly, advantageous to the popular classes.

The social function of the bipartition of the revenues shows itself under different aspects in other countries, but nowhere has it assumed so characteristic a form as in the United States. Thus in California the agrarian party and the big capitalists and manufacturers were united at first in opposition to the legislation demanded by the labouring classes to exclude the Chinese and repress the abuses of the railroad companies. But as the power of the big capitalists continued to increase they became overweening in their demands upon the landed proprietors. The latter thereupon made an alliance with the popular party led by Kearney, and supported the agitation toward the adoption of a constitution that was little short of radical. This alliance between landed property and the people resulted finally in the election of a convention which proposed a constitution that was subsequently approved by the people. The constitution adopted was as favourable to landed property as it was hostile to capital, for it burdened manufacturing industries with heavy taxes, forbade big monopoly companies to water their stock or employ Chinese labour, and confided the duty of determining railroad rates to a supervisory committee. This occurred in 1879. But the moment the landed proprietors, with the aid of the popular faction, succeeded in inflicting a defeat upon the rival revenue, they hastened to free themselves from their embarrassing ally and abandoned the popular party to its orrn designs. In fact, when it came the time to elect the legislature that was to put the new constitution into effect, the victorious proprietors took pains not to vote for the candidates of the popular party, but supported the candidates of the democratic party instead, thus scattering their votes and assuring the success of the

${ }^{1}$ Almost all the legislation relative to the labour question was due to the initiative of statesmen belonging to Tory ministries. The laws relating to factories and works, mines, navigation, hygiene, labourers' dwellings and education are all to be traced to the Conservative party. Chamberlain, "The Labour Question," Ninctcenth Century, November, 1892, p. 709 . 
Republicans, or, in other words, of the Conservative element. Thus the new constitution, though anti-capitalistic in spirit, came to be applied in an eminently capitalistic manner, and the sharp points directed at the big corporations were prudently blunted by its partisan executors. In this way the capitalist's arrogance toward the landed proprietors was checked, but all that part of the new constitution which looked to the advantage of the labouring classes remained a dead letter, with the exception of a single clause.

I say with the exception of one unique provision, for one article of this celebrated constitution has becn scrupulously applied, and has even constituted a point of departure for a general law of the National Government. I refer to the clause that prohibits the immigration of Chinese labourers This prohibition being the first legislative expression of the American's antipathy toward the Asiatic lahourer, gave fresh impulse to the popular agitation directed toward the deportation of the Chinese, which received its final sanction in the Scott Bill, passed by Congress in 1888 . Judging from this legislative victory of the American labourers, a number of writers, Sir Henry Maine among others, have attempted to show that in America political power is in the hands of the working men, who make use of it for selfish and reactionary ends. ${ }^{2}$ But we have already exposed the error that underlies such statements of construction, and shown that this victory of the American labourers (an exceptional victory, and almost unique in the history of the New World) was due to the unconscious hostility between landed proprietors and industrial capitalists. In the midst of the contest thus engendered the land owners were compelled to call upon the labourers for aid, and this afforded the latter their opportunity for insisting upon the exclusion of their Oriental competitors. But of itself this alliance would never have been able to maintain this Chinese wall against the Chinese if their admission had continued to be as essential as heretofore to lower the wages of American labourers and

'Bryce, loc. cit., iii., pp. $235-219$ it prossim.

${ }^{2}$ Maine, Essug on Pofuler Govermment. Several of Manie's remarks were utlered sume time hefore by Macalaly in his celelwalled letter to the Times of $23 \mathrm{rd}$.11arch, 1857 
assure capital a reasonable rate of profits. If capital ceded a point to the demands of the labourers it was only because the rapid increase of population had of itself effected the necessary reduction in the wages of American workmen, and thus rendered the importation of Chinese labourers superfluous, and perhaps even injurious to capital. Capitalists now found labour in their own country that was infinitely more capable, more intelligent and more efficient than the Chinese and only a little higher priced. They no longer had any motive, therefore, to create a systematic competition for such labour in order ultimately to depress its value.

If it is thus that the strugsle between the two kinds of revenues gives rise to provisions advantageous--though, indeed, in very modest measure-to the labouring class, we can readily understand that where no such contest occurs economic legislation preserves its essentially capitalistic character and continues to favour one or the other or both revenue classes at the same time. In Belgium, for example, where political power is an appanage of manufacturing capital, and where landed property plays but a secondary part in the direction of public affairs, social legislation is to-day unknown, and even the adulterations effectcd by liquor dealers can not be suppressed by law, in spite of the injurious effects upon the labouring population. In Italy likewise, where landed property predominates, or where more often a coalition is formed between rent and profits, legislation is inspired by narrow and selfish aims and constantly hostile to the labouring classes. Italy, indeed, has no law to protect the labour of children-1 mean no law that is really efficacious - though even India has provided such legislation. Italy also lays high protective duties upon cereals, which, though originally levied on the pretext of offsetting the importation of cheap provisions, still persist in spite of the rise in the price of food stuffs. Hence the sufferings of the Italian people, who are burdened with protective duties and scarcity prices at the same time. The looked-for reaction on the part of the capitalists that could easily prevent the evil is habitually disarmed by concessions of high protective duties upon manufactured products; and in this way the alliance 
between the two linds of revenue is sealing the ruin of the Italian people. ${ }^{1}$ In Germany the uncontested superiority of the large land owners and mine owners occasions high duties on eereals that the industrial classes are powerless to prevent," and sanctions syndicates among coal producers that raise the price of fuel enormously. Landed property is, indeed, so powerful that it can even afford to allow internal dissension to arise hetween the land owners and the mine owners, each of whom take exception to the other's usurpations. Elsewhere the political preponderance of protit occasions differential rates, which by diminishing the effect of distance lower land-rents. In America the law of July, 1890, which compelled the Secretary of the Treasury to purchase four and a half million dollars worth of silver every month was passed by the combined influence of the holders of silver mines and land owners, the former demanding a market for their products, the latter desiring higher prices for their produce. The Nckinley Bill was the result of the victory of the Republicans-large capitalists and manufacturers-who are insatiable in their demands for industrial protection. Everywhere, in short, the triumph of one form of income over the other, or a coalition between the two, gives a capitalistic turn to legislation and cheeks the tendency toward social politics arising from the original bipartition of the revenues. ${ }^{3}$

'We come upon analogous examples of this coalition between the different kinds of revenue in the past history of England. Thus in the eighteenth century the landeal gentry consented to the prohibition of the exportation of wool to the cxclusive advantage of the manufacturers in order to obtain in return the latter's adherence to a bounty of tive shillings on the exportation of corn. And before this commercial capital had already secured important advantages by enforeing the Navigation Act (see Adam Smith, Wealth of Nitions, i., 10; iv., 3).

${ }^{2}$ The recent commercial treaty between Gernany and Austria (1892), that lowers the duties on cercals and modifies the conditions inposed upon industry, may be regarded as a sympton of an approaching reaction in favour of industrial capital in the German Empire.

${ }^{3}$ Still more night be said. The creation of the new monetary unit in Austria, the crown, which is inferior in value to that which has up to this been current, appears to have heen instigated by a desire to favour a particular faction of the rich classes by lowering the value of the pourboircs! 
We can thus comprehend the peculiar character of the politico-economic development of the last few centuries. During the first period we find the State supporting the property system with provisions for the protection of industry and agriculture and by means of legislative intervention for the reduction of wages. Upon reaching the second stage protection of this kind disappears, the checks that the legislation of the previous period imposed upon individual liberty are removed, and the laissez faire principle rules supreme in political and economic life. During the last phase State activity is again resumed, but under a profoundly different form. Far from looking toward the protection and augmentation of property, State aid is now called in for the defence of the labouring man and the amelioration of his condition. ${ }^{1}$ After what has already been said the secret of this evolution is not difficult to understand. During the first phase of the capitalistic economy a politico-economic system is established that is advantageous to industry and hostile to the labourer, simply because, for a long period of time, property cannot persist except with the help of such energetic action on the part of the State. But economic advance ultimately renders all legislative interference on behalf of capital superfluous. Thus the very provisions which during capital's infancy formed an essential condition of its growth eventually became an obstacle in the way of its further development. Hence all forms of State interference for the protection of property cease in the interest of capital itself, and the progress of production and exchange goes on under the régime of perfect liberty. As yet the proprietary class shows no split into two revenue classes, each endowed with about equal force, either because a single class predominates without opposition in the politicoeconomic world or because property is not yet sufficiently consolidated and proof against reactions on the part of nonproprietors to allow any division of this lkind to occur. The absence of such a division into two revenue classes removes the

1. This politico-economic evolution is very well described by Cunningham (Politics and Economics, London, 1885, pp. 1-126. See also Jevons, The State in Relation to Labour). 
possibility of State intervention on behalf of the labourers; for, as we have already seen, it is just this bipartition of the revenues which is the occasion of such action and gives it its greatest force. During this period property is sufficiently strong not to require State intervention to increase its revenue, hut it is not yet sufficiently advanced to become differentiated into two sub-forms and thus cause State action in the interest of the labourer. During the third period, finally, the progressive development of property, accompanied by its increasing power, causes a differentiation into two partially hostile classes, whose political attrition engenders State action in favour of the poorer classes. Thus from the era of absolute laissez faire upon the bipartition of the revenues we pass over at once to an epoch of social politics. ${ }^{1}$ But even though social legislation proceeds thus from the proprietary classes, it can never go so far as to endanger the essential rights of property. Its direction is, moreover, entirely different according as one or the other of the two revenue classes predominates politically. In England, for example, where political supremacy belongs to profits, the provisions favouring the labourer are expressed in a series of laws (of which the English and I rish Land Acts constitute the most striking examples) restricting the rights of landed property. But in Germany, where rent maintains its political supremacy, State action in favour of the poorer classes is expressed in a series of provisions limiting the rights of capital, as for instance the limitations upon joint stock companics, the tax upon operations of the Bourse, and the compulsory insurance of working men."

${ }^{1}$ It was in 1832 that urban districts acquired an adequate representation in the House of Commons, and in 1833 the social legislation of the United Kingdom began.

2 In April, 1889, the large land owners of Germany passed laws for the compulsory insurance of aged and inflrm working then. In June, 1892, 185 Conservative deputies in the Reichstag dimanded legislation against the operations of the Bourse. In each case it was rent which allied itself with the people agiinst profits. Sonetimes, however, the labourers refuse to make an alliance with the revenues, as was the case in Belgium, where the working men, who were up to this ardent opponents of the duty on live stock, ceased their opposition at once when the bourgeoisic demanded the abolition of this tax. 
The social effects of this bipartition of the revenues are most clearly marked under the parliamentary system, where the conflicts thus aroused are so energetically fought out. But it is also possible to discover traces of such an influence in political systems where parliamentarism is unknown, and if we go back to past ages we shall find repeated examples of the operation of this same law. Let us look to the feudal epoch for example. During its first stages, after every trace of manufacturing industry had been obliterated by the disaggregration of the Roman Empire, landed property played a great rôle and the seigneurs were the only actors in the economic drama. But a division soon occurred between the revenue from land and the income going to the unproductive labourers who were found necessary to guarantee property against possible revolts of the serfs. Feudal revenues were thus divided into secular revenues and ecclesiastical revenues. This schism lay at the root of the persistent antagonism between the two classes of feudatories and gave rise to the subsequent grandeur of the towns, which profited by these disagreements among the ruling classes to obtain their freedom. Upon the appearance of the free town the political struggle entered into a new phase, for the revenues of independent artisans, who carried on the trade and industry of the guilds, now ranged themselves in opposition to the landed revenues that were shut up in the chatteaux. This latte: division of the revenues into the two fundamental forms gave rise to a struggle between the holders of landed revenues and the holders of industrial revenues, which for several centuries marked the course of the history of Europe and was the secret cause of her internal wars. In Italy the contest between ecclesiastical and secular revenues was fought out upon the field of battle in that gigantic struggle between the Pope, the chief of the ecclesiastical feudatories, and the Emperor, the head of the secular lords. In the hopes of winning in this bitter and uncertain struggle, each of the two adversaries sought the alliance of the towns, and they too, accordingly, entered the lists. At Campaldino, at Monteaperti and at Legnano both armed factions believed they were fighting for an ideal cause, the triumph of the Pope or the 
Emperor, and this was a necessary illusion, for only high ideals can lead brave youth to death. But whatever the delusion that led these gallant knights to combat, and whatever the ideal in whose cause they threw themselves into the fray, the unknown and invisible genius that animated the struggle did not descend from the heights of idealism but proceeded rather from the lower regions of economic utilitarianism. In this contest ecclesiastical revenues measured their strength with the incomes derived from secular fiefs. The condition of the disfranchised classes was thereby improved, for the alliance that the Pope and the Emperor each sought in turn to effect with the towns was sold to them dearly, and only accorded at the price of a series of concessions that hecame the foundations of the subsequent glory of the Italian cities. In Milan, where the schism between secular and ecclesiastical revenues was not so clearly marked, a furious war raged between the different degrees of feudal revenue, and prepared the way for the ultimate extinction of feudalism. Here the division between the great and the lesser nobility, the great vassals and the smaller vassals or vavasors, increased the power of the people, who finally revolted under Lanzone and established a democratic rêgime.

Thus the division in the feudal order gradually wealiened its force, and opened the way for the appearance of a new and more vigorous power which was ultimately destined to overthrow feudalism entirely. In fact, as soon as the Italian cities reached a condition of stability and established autonomous governments, the now predonsinant industrial revenue instituted a formidable revolt against the feudal revenue. A sanguinary war then broke out against the chatteaux as the result of this new contest between the industrialists and the feudatories, the former constituting the Guelph party and the latter the Ghibellines. ${ }^{1}$ The monent this new issue was drawn the two

I Villari (Le frime origini ed istituzioni della repubblici fiorentina-Politcrnico, 1866, pp. 7-10) and Toniolo (Sui rimoti fattori dilla potenza economica di Firrnze, Milano, 1882, pp. 55-56, 62.63, 92, etc.). Both show admirably that the contest between the Guelphs and the Ghibellines was but a struggle between personal and real property. It should be 
factions of feudal revenue straightway forgot their old quarrel and united against the common enemy which was threatening them. The Pope and the Emperor, heretofore irreconcilable, now tendered the hand of friendship and vowed the humiliation of the rebellious municipalities. The earlier contest between the two kinds of feudal revenue established the glory of the Italian cities, and this new struggle between the communes and the fiefs contributed no less powerfully to the elevation of the lower classes. As soon as the conflict broke out between the towns and the fiefs, the serfs fled from the estates of their lords and found freedom under the shelter of the city walls. And after the feudatories had been transformed into citizens, and the struggle between the Guelphs and the Ghibellines was continued within the walls of the towns, at every triumph of the Guelphs the privileges of the arts were extended to new classes of the population, and whenever the Ghibellines were triumphant they rehabilitated the meanest professions and raised the condition of the common people, whom they used as an arm against the bourgeoisie. Finally, when the feudatories were rendered powerless and excluded from all share in the government of the towns, and when the

remarked, however, that the struggle between the town and the country assumed a different course in France, in Italy and in Germany. In France the towns always represented the bourgeoisic and the country the feudatories, and the struggle between the two was incessant. In Italy the towns after having vanquished the feudatories absorbed them into their own systems, and the contest bctween the country and the towns was converted into a civil war. In Germany, on the contrary, the original inhabitants of the towns were themselves proprietors of the soil or feutatories, and it was only with the appearance of manufacture that an industrial population hostile to the proprietors grew up. The manufacturing classes then obtaincd a share in the political power heretofore exclusively exercised by houscholders, and when the new revenue form demanded a share in authority it was extended to artisans and merchants provided they could pay the price to rent a house (Arnold, Geschichte des Eigenthums, 1861, p" 255). .Civil struggles resulted which ended in the defeat of the feudatories who were driven back into the country. Hence the separation of the feudatories from the towns, which in Italy was the beginning of the development, was in Germany its final result (see Maurer, Städtcverfassung, ii., p. 540 ff.). 
bourgeois supremacy remained uncontested, it too split apart into two hostile factions, one composed of the well-to-do industrialists and the other made up of the common people, the small artisans and apprentices; and the struggle which arose between these two classes of the dominant revenue extended civil rights to the lower stratum of medixval society. ${ }^{1}$

In mediæval Italy the absolute separation between the political authority of the artisans exercised in the towns, and the political power of the landed proprictors exerted in the country, made it absolutely impossible for these two forms of revente to mect except in armed conflict. But in France the struggle assumed a more interesting political character. However great the economic preponderance of landed property orer industry, fiscal reasons made it necessary to accord the latter a nominal share in political power; for the fiscal demesne was no longer able to provide for the new wants of the public treasury. It was thus necessary to have recourse to taxes, and as these charges were bound to affect the bourgeoisie, it scemed better to appease them beforehand by allowing them a right to vote on the budget. It was solely with this thought in mind and not in the least through the generosity of the feudal lords that the hourgeoisie was given a right of representation in the States-General. Care was taken, however, that the representatives of the bourgeoisic should always find themselies in the minority orer asainst the representatives of the privileged orders.

'Nevertheless power always remained in the hands of the bous: genisic. Bonaceorsi, polestat of Regrio, having inclined to be fitourable to the poor, was turned down by the Chihellines after eight months'

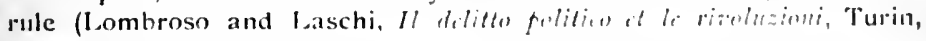
1890, p. 193).

${ }^{2}$ The same thing took place, but on a smatler scalc, in the lingdom of Naples (Giannone, loc. cit., iv. p. 264; vii., p. 270/and in Sicily in the thirteenth century. Exen in the lesser states and in the towns the same phenomemon is an be remarked. Thus De Tillet in his Hisfoire du duchi d'Aoste (Anste, 173s) insists upon the constant minority of the bourgeoisic in the States. (iencral of the Duchy of Aosta, and adds that in consequence the tatses fall exclusively upon the bourgeoisie. 
When the third estate came to talse part in the national assemblies, a political contest was inaugurated between the bourgeoisie and the feudal class which ran through several centuries and every year became more bitter. A double series of phenomena resulted from this struggle. On the one hand. there was the fundamental division between the feudal class and the industrial class, which benefited the serfs and hastened their emancipation; on the other hand, the usual conflict broke out between revenue and unproductive labour, resulting in a further division of the more powerful faction of the ruling class into the feudatories and the clergy who protected their rights. And even as the main contest between the two privileged orders and the third estate favoured the serf class, so this intestine struggle between the two privileged orders augmented the power of the third estate and increased its influence. In order to overcome its immediate rival each of the privileged orders invoked the aid of the bourgeoisie, and with greater assurance. in proportion as the latter's force was weak and feudal authority was assured. Thus the States-General for a long time presented the singular spectacle of an alliance between one of the two privileged orders and the third estate $\ln 1560$, for example, the nobility of Orleans united with the third estate to limit the pretentions of the clergy, and during the following year, in Pontois, the same factions agreed to compel the clergy to contribute their two-thirds to the liquidation of the royal debts. But as soon as the third estate demanded the substitution of a tax on realty for the personal tallage, harmony was at once re-established between the clergy and the nobility, and the two privileged orders then ranged themseives in opposition to the pretentions of the bourgeoisie. In the States-General of Blois the alliance between the nobility and the third estates became manifest in the year 1588 in propositions hostile to royal authority. But before this, in 1560, the clergy had endeavoured to detach the third estate from its alliance with the nobility and secure its aid in limiting the privileges of the nobles. And in the States-General of Blois in 1577 the clergy and the third estate united against the nobility in a demand to have the vote 
on the budget come before the assembled estates. ${ }^{1}$ This division between the two privileged orders increased the power of the third estate, and the latter, after gaining strength thus for several centuries in silence and comparative obscurity, in 1614 suddenly summoned together all its accumulated spirit of resistance and threatened the very foundations of feudal privileges. The feudal class could afford to allow these internal dissensions to go on so long as the third estate was held in subjection, but the moment the bourgeois class gave this exhibition of its force the dissensions among the factions of the dominant class suddenly ceased, and the nobility and clergy straightway forgot their ancient animosity to unite against the common enemy. As an historian of the States-General has said: "The alliance between the two privileged orders was effected under the stress of the bitter animosities that agitated the prelates and nobles in different ways against a turbulent bourgeoisie, which was attacking their privileges and minimisirg their influence either under the toga of the magistrate or through the office of deputy "."

The struggles that were fought out in medixval firance between the different kinds of revenue were not confined, however, to the rarely-opened precincts of the States-Gencral. They extended beyond these assemblies and occasioned noisy rebellions that were fecund in advantage for the working classes. One of the most noteworthy of such revolts was the League. This great event of the reign of Henry 111. was simply an alliance between the clergy, who were the great proprietors of the lingdom, and the mendicants of Limousin and Auvergne, together with the coal-men and water carries of Paris, against the nohility and the bourgeoisic. Its ephemeral

'See on this subject, Thierry, lissai sur l'histoire et la formation du tiers état, Paris, 1853, i., pp. 137-138, 197. De Tocqueville, L'ancicn rigime et la rivolution, Paris, $1866, \mathrm{p}, 128$. "Whenever the irris found llumselves in opposition with the scigneurs, some advantages for the people always came out of the struggle" (Saint-Simon, Dn systime imbstricl, Paris, 1821, pp. 133.134).

${ }^{2}$ Picot, Histoire dis Etals Giniranx, P'aris, 1572, ii., pp. 238, 389; iii,, p. 368 . 
success brought with it a number of measures advantageous to the popular classes, among others, the remission of rents due by poor tenants. Another still more turbulent conflict broke out a little later between the different factions of feudal revente in the war of the Fronde. This was an insurrection undertaken by Parliament, in alliance with the more important and higher paid administrative bodies, against the Government, which had attempted to retrench somewhat the immense perquisites attached to the numerous offices. In a word, it was a revolt on the part of unproductive labour, judicial and administrative alike, against the feudal revenuc which had endeavoured to restrain the clemands of its allies. This fleeting alliance between the rebellious unproductive labourers and the higher nobility, which was itself a victim of the monarchy and the dominant revenue, allowed the Councils and Parliament to hold their own momentarily against monarchical power, and force through a number of reforms dictated by liberal ideas. And though the resistance thus offered was soon overcome by the deleat of the Fronde, this temporary disagreement between the two revenue factions still had certain beneficial results that showed themselves to their full extent later on. It was to this conflict, in short, that a large number of the provisions, whereby Colbert later regenerated the French finances, owed their origin. ${ }^{1}$

Going back to a still earlier period we meet with the same phenomenon. Thus in ancient times we find this contest between landed property and manufacturing interests turning inevitably to the advantage of the slaves. Thucydides recounts that in Corcyra, at the height of the struggle between the optimates and the people, or, in other words, between the land owners and the artisans, both factions endeavoured to effect an alliance with the slaves by promising them their liberty, and that the latter chose to range themselves on the side of the people asgainst the optimates. ,When war was declared between the Spartans, who were conservative agriculturists, and the Athenians, who were liberal industrialists and traders, the former offered to enfranchise their Helots provided they would

${ }^{3}$ Clamageran, Histoire de l'impât en France, ii., p. 568 ff. 
fight on their side. ${ }^{1}$ In Rome also the struggle between the great landed proprietors, represented by the Senate, and the great capitalists, represented by the Gracchi, i.e., the contest between the two factions of the rich class, benefited the plebeians, who received lertile lands with the necessary capital to cultivate them.:- The plebeians' revolt against the patricians compelled them in like manner to ally themselves with the lower classes of society and enrol artisans and freed men in their tribes." "We see from history that it was to the labouring class-to the ser's of industry-that the plebeians appealed in their eternal struggile with the patricians. If we desire to understand the history of the Roman oryanisations of worling men, we must stuly the history of the civil wars at Rome. The corporations were, as it were, for sale to the highest bidder. Among the organisations of worlsing men, Marius found devoted supporters against his famous rival; while Sulla, on coming into power, wishing to be avenged for this hostility of the corporations, struck them down with a hand of iron. Catiline's flattering but interested acts of liberality were likewise intended to gain numerous supporters among the corporations. Another agitator, no less celebrated, Clodius, succeeded in enlisting the favour of the working men by means of all sorts of gratuities, immunities and calculated senerosities. In the popular assemblies the colleges of worling men accordingly alwalys cast their votes at the motion of the Tribune, and by their turbulent elamour prevented his adversary from speaking." In this way the lower classes of society prolited by the strugrgle between the difierent factions of the ruling class, and the contest even benclited the

1 Thucydides, Mistory, liv. iii, ch. ix.; liv. iv., ch. ix. "The following day the optimates and the people fought a litle with arrows and with everything that could be hurled, and both parties sent to the villages to asls the slaves to com: 10 their :tid, promising them their freedom. The latter chose to ally themselves with the people." In like manner during the struggle with her Americall colonies, linglind promised freedom to such slaves as took her side andinst the colonists.

"Roscher, System, iv., p. 2ti9. Lange, Roniseht Alterthumer, i., p. 671. Bertagnolli, Vicende dell' agriolfura in Ilalide, lssi, p. 111.

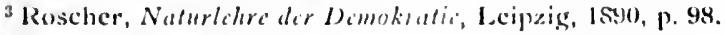

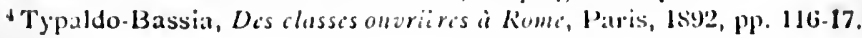


unhappy slaves. Thus while the struggle between the patricians and the plebeians was at its height, the condition of the slaves was somewhat better, and the revolt of Spartacus was also made possible by this division of the ruling class. ${ }^{1}$ The bipartition of the revenues is the salvation of the proletariat!

We may here take occasion to resolve the apparent contradiction with which we are confronted. If property be the basis of political power, how does it happen that the State sometimes takes energetic action against one form of property ? The preceding considerations furnish us with the key to this enigma: when one form of property predominates economically and gains political supremacy, the State, which is the organ of this dominant faction, is naturally driven to repress the rival form of property. A partial socialism arises from this which keeps down one form of property in order the better to encourage the other. Thus Solon's Seisaktheia was effected through the influence of the economic and political influence of debtor proprietors who used their power to humble their creditors. Again, the massacre of St. Bartholomew was simply the result of an insurrection on the part of the Catholic bourgeoisie against the Huguenot nobility; and the revocation of the Edict of Nantes was likewise instigated by the Catholic townsmen of France who, finding themselves overwhelmed by the industrial competition of the Protestants of Nimes and other more flourishing cities, insisted upon the expulsion of the Huguenots. But the most striking examples of such phenomena are to be found in modern eastern monarchies, like Persia and Turkey, where property is but poorly guaranteed and open to continual extortion from the sovereigns and the army. In these Oriental states property assumes two fundamental forms: the productive property of merchants and agriculturists, and the military holdings held in feudal tenure by the chiefs of the army and their followers. ${ }^{2}$ The janissaries, for example, are vassals of the Crown who receive landed

${ }^{1}$ Roscher, Naturlehre des Caesarismus, Leipzig, 1888, p. 13.

${ }^{2}$ See for example, Comte, Traité de Législation, Brusscls, 1837, p. $270 \mathrm{ff}$. 
property in return for their military service. ${ }^{l}$ The Mussulmen of Sicily, in like manner, were wont to pay their soldiers by assigning to each a share of the Kharag, that is to say, by allotting to every soldier a pension drawn from revenues that came to the State from the land of certain provinces. Then the soldiers were commanded to collect the Kharag themselves, hut this converted them into gabelers and extortioners, and gave them an actual right of property over lands in which they originally possessed but a fiscal claim.2

When omnipotent in the State, military property frequently commits excesses against the inferior orders of property which are unable to resist its claims. Hence the extortions and incessant abuses that productive enterprise is forced to submit to at the hands of the State when the latter is the organ and humble servant of military property. Such was the spectacle that Rome presented during the last days of the empire, when the military holdings of the legionaries crushed out productive property through the instrumentality of the State. The same thing occurred in mediaval Europe when the feudal lords and their vassals loaded bourgeois property with abuses and exactions." In the German towns, likewise, during the rule of the feudal seigniors, it was only landed property that obtained the protection of justice, and neither the courts nor the communes were compelled to protect personal property. The adulteration of coinage was also but a disguised form of usurpation which feudal property carried out to the detriment of the bourgeoisie through its creature the State. The evil accordingly disappeared as soon as the bourgeoisie came into power. Finally, the laws against usury and the persecution of the usurers during the midule ages were largely the result of a reaction on the side of landed property, hurdened with debt,

isce in this connection Ranlice's splendid comparison between the modern systen of paying armes with money and the Oriental system of rewarding military service by granting a plot of land to each soldier

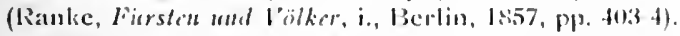

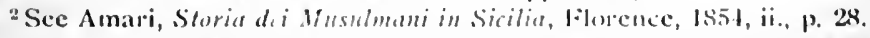

${ }^{3}$ For the political domination of the procers - the military proprietors among the Gauls-see Winspeare, Shorio denli abrsi foudeli, Naples, 1883, pp. 304.6. 
against the creditor capitalists; just as the persecution of the Jews in modern Russia is the result of a reaction cn the part of Christian usurers and commercialists against their lsraelitic competitors.

It is worth while to remark in this connection that the guarantee of property does not, as economists pretend, rest upon the protection accorded it by the State through the excellence of its constitution and the foresight of its government officers. This guarantee is rather derived from the organic constitution of the State itself and is only secured under certain conditions of economic development. When one class of proprietors predominates over another, the guarantee of the subordinate form of property is inevitably weak because the State, representing as it does the prevalent form of property, exploits the wealser in its own interest. Nevertheless the manner of accomplishing such oppression differs, according as one or the other form of property predominates. When military property prevails the subordinate property is subjected to violent exactions, but when, on the other hand, the predominant form is merely a species of bourgeois property, the inferior form is discriminated against in a less brutal manner through legislation.

There is one other very important phenomenon which the bipartition of the revenues explains, namely: the historical possibility of reform movements and the partial success of their leaders. The men of genius who succeed in giving fresh impulse to the power of the State clo so by turning this organic conflict between the two property classes to the account of the people. Robert Peel, for example, availed himself of this conflict in England with marvellous ingenuity, by making himself alternately the champion of the landed proprietors against the capitalists, and of the capitalists against the landed proprietors, and by taking advantage of their mutual hostility to introduce legislation beneficial to the poorer classes. In our day, again, one of the most active and powerful reformers, Bismarck, simply profited from the inevitable antagonism between the proprietors of the soil and the capitalists to obtain, with the consent of the former, laws limiting the expansion of capital and ameliorating 
the condition of the working men. ${ }^{1}$ From the very fact that the reformers who obtain big results do so by the grace and with the support of the ruling class, it is easy to understand that they gain their ends only so long as their activities are not injurious either to the predominant revenue-form or to the essential rights of property. But the moment the reformer, intoxicated by success, attempts any measures that threaten property, the owning classes forget their internal dissensions and unite in a compact alliance to discountenance the movement. Then the too audacious reformer suddenly sees his glory fade. The prestige of his genius is powerless to defend him in the war now waged upon him by the dominant classes. Secret attaclis are instituted atgainst him, unforeseen conflicts arise, tenacious resistance is offered to all his reform measures, until the reformer at last tinds himself inexorably condemned to the status of a revolutionist. History hats something to tell us of attaclis of this lind instituted by the dominant class against those andacious enough to threaten its power. Indeed the grandest and most sublime of alt reformers owed his anguish to just such a coalition among the owning clatsses against his socialistic propagandia. "It was not in opposition to the Mosaic law, but rather in hehalf of its literal interpretation that Christ took up his work," an impartial writer observes. "His revolt was not directed against religious principles, but agatinst property, and for this reason he was obliged to suffer death. This explains, too, why the Pharisees opposed him. They constituted plysicatly and intellectually the fine flower of Judaism. They were the best informed and the wealthiest. And though they might talic pleasure in discussing fine points

${ }^{1}$ By this political flan Bismarck realised what latssalle before attempted, whose Socialisn really amounted to an alliance hedween the proletariat and the large lamb owners against the captotlists (Nars,

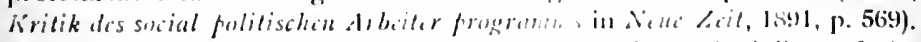
And such, moreover, is the fundaunental idea of lle Socialism of the Chair and Catholic Socialism, beth of which are hut the theoresical product of an alliance between landed properly and the labourers against capital. The same may be said of Tory Socialism in England. On the other hand, economic l.iberalism and agrarian Sociatism represent a reaction on capital's part agatust the dematuds of landed property. 
with a religious sectarian, they hated him who drove the money changers from the temple, and crucified the man who declared himself an adversary of the publicans." 1 Socrates would never have been brought to the tragic end that Plato sadly tells us of had he not so bravely opposed the democratic party then dominant in Athens, had he not cast reflections upon elections by lot, then so dear to the popular classes, and had he not gone so far in his reforms as to threaten the kind of revenue that was then all powerful. ${ }^{2}$ In times less distant Savonarola mounted the pyre, a victim of the fury of the landed proprietors, upon whom he desired to lay a tax, up to this paid by the industrial classes alone. ${ }^{3}$ And even if the ruling class does not have the improvident reformer put to a cruel death, it at all events renders him powerless and frustrates the realisation of his designs. Colbert furnishes us with an example of this. The moment he attempted to restrain the nobility of the robe and the sword, the court parliament and the financiers all combined against him and worked in an underhand way to overthrow him. Colbert was accordingly obliged to reduce his grand financial reform to the miserably sterile plan of Commissions of Parlia$m e n t$, which were to meet at a stated time of the year" to examine the financial condition of the provinces. Later on in French history Turgot's reform projects met a similar fate. This intelligent minister was removed from power by a coalition of all the privileged classes. In our day Gladstone's fall in 1886 was due to a combination between land owners and British capitalists who opposed the redemption of Irish lands advocated by this audacious reform minister. In Brazil an intelligent prince refused to wait for the natural course of economic evolution to effect the downfall of slavery and abolished the system by force of law. But the holders of the revenues

${ }^{1}$ Hertzka, Die Gesetze dor socialcn Entwicklung, p. 286. See also Nitti's great work, Sur le socialisme catholique, Turin, 1891.

2 Zeller, Geschichte der griechischcn Philosophie, 4th ed., Leipzig, 1877, ii., pp. 177-86.

${ }^{3}$ Toniolo, Scolastica ed umanismo, Pisa, 1888. Rava, Celsi Mancini, etc., Bologna, 1888. 
The Bipartition of Revenue and Soz'ereignty. 205

destrojed by this reform rebelled, and a coalition of slave owners and military men precipitated the revolutionary monarch from his throne-an eloquent example, indeed, of the incapability of absolute power to disrupt the revenue system, whose creature it is and whose docile instrument it must under pain of death remain! 


\section{CHAPTER III.}

MANIFESTATIONS OF REVENUE AND SOVEREIGNTY.

If political power be thus an emanation of economic revenue, the natural tendency of acts of sovereignty must be to facilitate the development of capitalistic income and favour its holders in every possible way. Indeed, the slightest examination of the workings of the State is sufficient to convince one that all privileged and powerful classes make use of their authority to advance their own interests. ${ }^{1}$ In short, with the exception of the influences already mentioned of the bipartition of the revenues, all the efforts of political authority converge toward one supreme end: to guarantee and augment the income from capital. Finance, administration and foreign politics can thus only be explained when regarded as the outcome of property interests.

\section{I.-Financial Policy.}

The economic constitution of the State, with its exclusive dependence upon the economically dominant class, is clearly exhibited when we examine the acts of political sovereignty in financial legislation. The first fact to strike our attention in this connection is that at every historical epoch the dominant class has loaded the subjugated class with the whole, or a large portion of the burden of taxation.

This phenomenon was not very marked during the earlier period of the Roman economy; for the principle of equality formed one of the best features of this system of taxation. Thus the constitution of Servius, though it established political sovereignty tairly upon the hasis of property, nevertheless provided that belli pacisque munia, non viritim ut antea, sed

1 John Stuart Mill, Principlcs of Political Economy. 
bro habitu pecuniarum fievent. ${ }^{1}$ When it became necessary to raise an extraordinary tax after the second Punic War, it was only levied upon the rich; and even up to the time of Constantioe direct taxes upon capital and landed property were usually levied in cxact proportion to possessions of the tax payer. it would nerertheless be a mistake to regard thesc facts as exceptions to the usual relation of dependence existing between the political and the economic constitutions, or as contrary to the constant tendency of the proprietary classes to tax the non-proprictors; for the plebeians, who werc thus charged proportionately-or pcrhaps entirely cxempted from taxation-were not, as the modern lahouring classes, entirely excluded from ownership, but participated in the property system, either directly as small proprictors, or indirectly as unproductive lahourers. The only inhabitants entirely excluded from the rights of ownership were the slaves, and they. for this reason, escaped taxation. Taxes could thus only be levied upon proprietors, and for a long time the hurden was divided equally among them. If, indecd, the owners as a group could have taxed those who possessed nothing, the large owners would not have succeded so readily in shifting the burden upon the smals owners. ${ }^{2}$ As it was the growth of large revenuc soon began to cxercise its influence upon Roman finance, and when Constantine established the sordidn muncra and the cirtrondinarin tribute, hoth very heavy taxes, the chase for immunities hegan, and therewith a shifting of the burden from the rich to the poor. "Inveniuntur plurimi diritum," Salvian cxclaimed, "quorum tributa pauperes forunt . . arljectiones tributnrias ipsi interdum diates faciunt, fro quibus pauperes snlaunt." "3

The phenomenon was more clearly marked during the feudal periou when the scigneurs assured themselves of their own

'Titus livy, Histıry, i., 42.

${ }^{2}$ Among the Jews, likewise, taxes were proportional in wealth, some. times even falling exclusively upon the more wealthy (Sals:ador, Mistoire

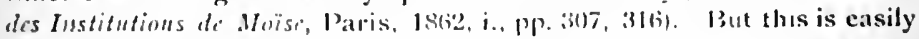
explaned from the fict that the dews were a nation of proprictors, who were in no position, thereforc, to shilt the burden upon a class deprived of the liberty of choice.

3 Salvian, De (iubermatione Dci, v., 7 ; iv.. (i. 
immunity from taxation by shifting the entire burden upon the shoulders of the bourgeois and agricultural classes. It was impossible, however, for this plan to be carried out at the outset, for a very simple reason. True, the classes that held property also exercised political sovereignty; but before the proprietors could cast the burden of taxation upon the other members of society, it was necessary that the revenues of the subordinate classes offered sufficient margin to allow them to bear the necessary charges. And inasmuch as during the early days of feudalism the revenues of the bourgeois class were still too small to allow them to bear the burden of taxation, it was necessary that the incidence should still rest entirely, or in large part, upon landed property. England furnishes us with a remarkable example during the reign of Richard I. (1243), when taxes were levied upon proprietors exclusively, and in proportion to their fortunes or their titles of nobility, as these furnished the most exact standards of valuation. Thus the counts were taxed twenty silver marks, the barons ten, and the lnnights four. ${ }^{1}$ In France, likewise, during the first phase of feudalism, there were numerous taxes that only affected the well-to-do. We need not be surprised, therefore, to find that during this period high tallage was a mark of distinction or that the rich made it a point of honour to pay high taxes. ${ }^{2}$ Later on, when the bourgeoisie emerged from complete poverty, the class became taxable to a certain degree, but it could not yet bear the entire burden of taxation, despite the fact that taxes played but a small role in the State finances, as public expenditures were for the most part met by the revenues of the demesnes. During this period the feudal class succeeded in shifting a portion of the taxes upon the bourgeoisie and in establishing a sort of tributary justice by instituting a proportional tax upon property. But before long the proportional

'Sinclair, History of the Public Revenue of the British Empire, London, 1803, i., p. 129. Comparing this 'period with the modern epoch, Sir James Steuart's remark would appear to be true, namely, that under the pure monarchy the prince taxes wealth preferably, but in the limited monarchy, poverty (Inquiry [etc.] on Political Economy, Basel, 1796, ii., p. 119).

${ }^{2}$ Boisguillebert, Détail de la France, p. 173. 
tax became an equal tax, for it affected large and small owners alilie and ended by exempting the former.' As soon as the increasing revenues of the bourgeoisie became more evidently taxable, the feudal class next hastened to proclaim its own immunity from the charge. But as the bourgeoisie was still unable to bear the entire burden of taxation, and as the feudal class was now legally exempt, State revenues could only be properly provided for by introducing a general system of indirect contributions, which alone could overcome the legal immunity of the seigneurs and compel them to malse up that part of the public contributions which the bourgeoisie was unable to supply. ${ }^{2}$ Finally when the wealth of the hourgeoisie increased to such an extent that it was finally in a position to bear the whole burden of taxation (and this point was reached about the fourteenth century), the entire public expenditure came to be provided for by contributions from the bourgeois and agricultural classes. The imposts then laid upon small proprietor's furnished a powerful means of breaking up their holdings; and still heavier were the burdens laid upon the serfs and coloni who were employed in the cultivation of the soil."3 Frederick the Second's bold attempt to establish equality of taxation in the kingdom

'Schmoller, Epochen de'r proussischen Finanz-politik, 1\$77, p. 49.

${ }^{2}$ Although modern cconomists regard indirect taxes as unjust and injurious to the labouring classes, Colbert, nevertheless, proposed a systen of indirect contributions as a means of obtaining tributary justice (Clement, Mistoriv de la aie at de liulministrution de Colbort, Paris, 1846, p. 97), and Stcuart declared that the principal advantage of such indirect contributisins was to make the entire hurden of taxation fall upon the rich (lic. cil., p. 197). He contradicts himself, however, a little further on (p. 193). This opposition betwen the opinions of the ancicnts and the moderos is easily accounted for when we remember that during the midelle ages indirect taxes affected especially such objects as were not of prinal necessity, while the laxation of fool-stuffs is an arrangeunent of modern times. Then, too, the fetalil classes were nornally excmpt from direct taxation, and indirect taxes thus furnished the principal means of sabjecting them to taxation at ail. Such was likcwise the effect of the regales, and it was for this rason that they were so bitterly (pposed by the aristuratic classes (Schmoller, Epochen der prenssischen linanz, etc.. p. (it).

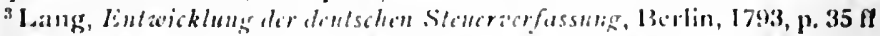

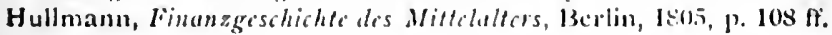


of Naples was reduced to nothing by his successors. ${ }^{1}$ In France it was still worse. "The rich," wrote Boisguillebert, "are beginning to practice injustice in the distribution of taxes by shifting them upon the poor, thus making it necessary for the latter to sell what little they possess." 2 "A tax that would scarcely have taken ten pistoles from the amusements and expenses of the rich would, with the current revenues, often have sufficed," Forbounais wrote, "to carry on a war without the labourer even hearing of it except in the public prayers. But if a decree imposing a tax of this kind had been published, one would have heard nothing but the outcries and complaints of two or three million men: Demand nothing of us, draw upon the country; the people suffer, it is true, but the general good outweighs private interests, and it is not good for this class of people to be well-to-do." 3 In vain Courts des Aides in 1613 required the tax-collectors to enter every house, those of the nobles as well as those of the people; its decree remained a dead letter. Under the ministry of Richelieu a magistrate proposed equality of taxation, but even this audacious minister drew back, appalled at such a measure which would surely have cost him his office. Not being able to reach the nobility and clergy, Richelieu then burdened the bourgeoisie with the taxe des gens aisês, which fell most heavily upon the working man. In 1710, when the minister Desmarets found himself compelled to lay a tithe on all revenues, he consoled the king, who was grieved at taxing the nobility, by assuring him that the nobles would find ready means of escaping the levy. And such, indeed, turned out to be the case. ${ }^{*}$ Finally, when Calonne, brought

${ }^{3}$ Giannone, Storia, vi., p. 45.

${ }^{2}$ Boisguillebert, Détail de la France, ed. Daire, p. 179.

${ }^{3}$ Forbounais, Recherches et eonsiderations sur les funances de la France, Basel, 1758, ii., p. 83. At the same time Rousseau wrote: "He who has little pays much, and he who has much pays little. If the least article of luxury or display were attacked, all would be lost; but so long as the rich are content, what does it matter whether the people live?" (Lettre a d'Alenbert sur la comédie, Amsterdam', 1758, p. 217).

${ }^{4}$ Michelet, Histoire de France, Paris, 1879, vol. xiv., p. 189 ; xvi., p. 285. In Italy in the seventeenth century "if it came to a question of voting taxes, the nobles, sure of their own immunity, would vote for the tax, and then cure control of the customs, and aggravate the misery of the 
face to face with the ruin of the French finances, proposed a territorial contribution affecting all proprietors of the soil, the privileged classes arose as one man and drove him from power. ${ }^{1}$ Brienne, who succeeded him, had no better success in submitting the privileged classes of society to taxation.

Under the wage system the general conditions remain about the same, though the form of oppression has been considerably modified. Like the nobles of old, the bourgeoisie finds no difficulty in throwing the burden of increasing taxation upon the poorer classes; and it is just in this that the marvellous ingenuity of capital is most clearly displayed. Mlodern capitalists, after having proclaimed the principle of universal political equality, could not logically provicle for their own immunity by means of a law to that effect. On the contrary, in principle at least, they maintain the proportionality of taxation-the dogma so boldly defended by its earliest exponents, Vauban and Boisguillebert. Nevertheless, during the early stages of the wage-economy capital did not hesitate to establish a system of taxation particularly favourable to large fortunes. Thus in England, for example, in the eighteenth century, the inheritance tax and the stamp duty both became less and less of a burden as wealth increased and finally dwindled to nothing

people through this monopoly" (Ferrari, Lat Minti di Vico, Milan, 1837, p. 71). Moreover, any change in the dominant class brought with it a corresponding change in the financial system. Thus when the artisans and commercial classes ruled in Venice, equal taxation was vigorously enforced (Emiliani Gindici, Storia politica dei municipii ituliani, Florence, 1855 , ii., p. 512). In Florence, too, when the democrat ic government was instituted the dime was established, which burdened landed revenue exclusively, leaving industry and commerec exempt (Canestrini, La finanza e l'arte di stuto della ripubblica fiorentina, Florence, 1862, pp. 315 319). When the common people of Florence (who were made up not of proletarians but of small artisans and proprietors) acquired political power during the last days of the republic, and during the early days of the government of the Medici, who relied upon popular support, they introduced proportional taxation, and thus threw the burden upon the large proprietors (Villani, Cronica, liv. v., p. 180 ff.). Ricca Salerno, Storia critica delle dotirine fintmeiaric in Italia, Rome, 1881, p. $37 \mathrm{ff}$.

'Vührer, Histoire de la detle publique en France, Paris, 1886, i., p. 311. 
upon fortunes of a certain amount. ${ }^{1}$ And to-day in West Virginia houses pay a tax which is proportionately low as their value is high; and the large landed proprietors, by corrupting the expert appraisers, succeed in rendering the burden insignificant. In Germany also, where wealth is more centralised, the plutocrats long ranged themselves in opposition to a scheme of taxation that promised to affect them adversely. ${ }^{2}$ Down to 1873 the Prussian law provided that the income tax paid by one tax-payer should never exceed 7200 thalers, which amounted to complete exemption for all incomes over 240,000 thalers. And the large feudal proprietors in Prussia still combat Miquel's plan for an income tax declaring that he would rob them of their right of immunity. This obliging minister seemed, indeed, disposed to indemnify the landlords for their loss by assigning them a fund equal to thirteen and a half times the amount of the annual tax; but they demand still more, and insist upon a capital equal to twenty-nine times the tax, plus an indemnity for the taxes they would be obliged to pay upon their pensions, and upon the emoluments they receive. ${ }^{3}$

When it is no longer possible to obtain immunities directly, the bourgeoisie seeks to secure exemption by indirect means. At first they succeeded in lessening the tax upon wealth through the system of declarations which allows the tax-payer to fraudulently reduce the taxable sum. Hence, under the influence of the bourgeoisie, the modern aversion to the cadastre has arisen, and now-a-days continually greater preference is given to taxes on valuation. Moreover, by setting forth and exaggerating the difficulties in the way of the taxation of personal and industrial capital, the bourgeoisie has forced some States to abandon the taxation of a considerable portion of capitalistic wealth. As a result, the tax imposed on the income derived from invested capital, and more particularly

${ }^{1}$ Vocke, Geschichte der Stcuern des Critischen Reichs, Leipzig, 1866, p. 85. ${ }^{2}$ Nebenius, Offcutliche Credit, 1829', p. 218.

${ }^{3}$ Since these lines were written the Prussian finance minister has presented another project in which still greater concessions are made to the proprietors. They have now reached the point of abolisning the iand.tax. 
from landed capital, affects the consumer injuriously, for it assesses a special form of profits and is consequently shifteci upon the purchaser. During this historical phase even the direct tax has in this way become an indirect burden especially affecting the poorer consumers. Thus from 1692 to 1802 England retained a light property tax, even though the public expenses were almost exclusively provided for hy indirect taxes. By rights this tax, besides burdening landed property, should likewise have assessed industrial and commercial capital, and also the emoluments of the liberal professions; but it became, in fact, an exclusively territorial burden on account of the difficulty of determining with any degree of exactness the revenues derived from industries and employments. ${ }^{1}$ When reduced thus to an assessment on landed revenue alone, this tax is usually shifted upon the consumer; it becomes, in other words, an indirect tax upon the labouring classes. Petty, the greatest economist of the seventeenth century, indicated this very clearly in these words: "A land-tax is an irregular tax upon consumption". The writers of this epoch evidently hail this fact in mind when they regarded the taxes as the cause of the misery of the working man. ${ }^{2}$ During this period the taille prevailed in France, and as this simply amounted to a tax upon the profits of the least fertile lands, it was accordingly shifted upon the consumer by raising the price: or, to put it differently, it was an indirect tax that differed from the rest only in this that it raised the rent of the proprietors. ${ }^{3}$ And even to-day in

'Vocke, lac. cit., p. 501. Scligman, General Property Tax, New York, 1890, pp. 5 1-52. Dowell, Mistory of Taxation and Tatis in Englund, London, 1888, ii., pp. 49-51. Davenant, "An Essay on the Ways and Mcans," in his Works, i., p. 51. This last author complains that capital not invested in fand is not assessed. See also his "Discourse on the Puhlic Revenues," ibid., p. 251.

${ }^{2}$ Howlett, The Insufficicucy of the Cituses to nithich the Increase of our Poor is ascribed, London, 1785, p. 70. Sec also 131:the, ()bscriations on the E.ffects Produced by the Expenditure of (iozernm, nt, london, 1823, p. 83.

${ }^{3}$ Aecerding to Boisguillebert, who wrote in $16: 97$, the trille affected the proprietor of the least fertile land, wiw, not heing able to indennify hinself from the consumers, by raising the price, hat to give up cultivation entircly (loc. cit., pp. 203, 2(b), ctc.). But liorlounais, who wrote in 1758 , aftirmed, on the contrary, that in screral provinces the 
America, where the prevailing high wages can bear a large share of the public charges, direct State taxes assess real property almost exclusively, and are thus transformed, in fact, into indirect charges upon the consumer. ${ }^{1}$

But there is really no necessity for capital to resort to these round-about methods of shifting the taxes upon the labourers, since it can always assess the wages of the indigent classes by taxing articles of primal necessity. Thus personal capital, however large, succeeds for the most part in escaping taxation, while the wages of labour, which by reason of their very smallness, ought, it would seem, to be exempted, are burdened with the charge, thanks to the ingenious artifice of indirect taxes which seize upon the wealth of the working man in the very act of consumption, that is, at the only moment when it can be assessed.

Thus the economic and political triumph of the bourgeoisie coincides with the systematic and general introduction of the system of indirect taxation. Holland, the classic land of modern capital, made this system known to England, and in 1643 the English Parliament established the first excises upon the manufacture and sale of beer and cider. The people, ignorant of the effects of these taxes, and believing that they affected the manufacturers, accepted them without a murmur; but the bourgeoisie, in pressing the matter, attempted to forestall popular indignation by proclaiming the transitory nature of

price of food-stuffs was increased by reason of the tax, and that an increased rent was accordingly accorded to the large proprietors who were exempt from the tax. This was the case in Languedoc (loc. cit., i., p. 320). Such was precisely the effect that Ricardo attributed to the taille (Princifles, p. 108). It is true that the taille might have one or the other of these effects. When it was exclusivety a real tax, that is to say, when it assessed the least fertile lands, it might be shifted upon the sonsumer; but when it was a personal tax, and as such assessed all the proprietors or farmers of the lowest class, it could no longer be shifted and remained a charge upon those who were assessed. The taillc was thus a tax which affected either the producers placed in the most unfavourable conditions, or the consumers (see also Clamageran, Kiistoire de l'impôt, ii., pp. 93-94, 595-96, etc., and Adam Smith, Wealth of Nations, p. 675 ff.).

${ }^{2}$ Ely, Taxcs in Amcrican States and Cities, New York, 1888, p. 72. 
these new taxes. In spite of this assurance, the excises continued to increase considerably. Charles II. donated the landed proprietors with a larger part of the taxes they owed and substituted indirect taxes. ${ }^{1}$ Leading scientific men, Hobbes, Petty, Temple, De Wit, and a number of others extolled this new system of taxation. It was in vain that William III. endeavoured to introduce some sort of proportionality into the system ; he was met by a coalition of land owners who demanded that the excises be maintained and increased. In fact, they became more numerous from this time on. In 1723 a large number of imposts were done away with, either wholly or in part, and replaced by a tax upon production. Ten years later, Walpole, the bourgeois minister, conceived the plan of meeting all the requirements of the budget by means of indirect taxes alone, and he only abandoned his project when he saw the popular indignation that the project aroused.2 Through the influence of the bourgeoisie in Parliament indirect taxes remained, however, during the eighteenth century and continued into the early part of our own century; for, despite the poverty of the people, taxes had to be laid upon the labouring and industrial classes in order to meet the expenses of the antiNapoleonic wars. These taxes remained after the termination of the war, as it was decided to employ the surplus in the budget to lighten the taxes that weighed upon property.

The financial policy of the bourgeoisie had the natural effect of occasioning popular discontent. Thus the revolt of Masanicllo was the result of a tax on fiuits $;^{3}$ the uprising that occurred in Naples in 1767 was occasioned by a tax on figs; in Holland the tax on fish had a like effect; in England the Wat Tyler rebellion was due to the poll tax, and Jack Cade's rebellion followed excessive taxation.' But the bourgeoisie was not deterred by these rebellions. In France the indirect taxes

'MacCulloch, "Traite des effets des imp.its," Bibl. dell' Econom., p. 44.

${ }^{2}$ In the lsingdom of Italy, established by Napolion I., the minister Prina conceived the same idea; in fact, he owed his tragic end to this project of taxation and the St:Imp Act.

"Giannone, loc. cit., viii., p. 4.

+Buxton, Finance and Politics, I,ondon, 1888, P'reface. 
prevailing throughout the eighteenth century were only abolished by the Revolution, ${ }^{1}$ which instituted a system of taxation under which wealth alone was assessed. But this modification was simply the product of a corresponding change in the organic composition of the State, which (through a series of influences of which we shall speak later on) temporarily accorded political sovereignty to the French people. And as soon as the bourgeoisie gained the upper hand again under the Directory indirect taxes were re-established. A progressive tax was, however, maintained, and this rendered the Government obnoxious to the bourgeoisie. The Directory was accordingly overthrown and a régime of purely capitalistic finance was inaugurated, which has since continued without further interruption. Even to-day taxes in France fall most heavily upon the labouring classes. All the taxes necessitated by the loans contracted after the war of 1870 fall upon the poor people, who in this way pay the interest on the capital loaned by the rich creditors of the State; while the payment of the five milliards indemnity occasioned no increase in the land tax. ${ }^{2}$ In Prussia the tax on milling, which affected the agricultural classes, was long retained in preference to taxes that would have affected the.industrial classes, and this was clue to the fact that the industrialists possessed political influence which they used to their own advantage. This tax that weighed so heavily upon the labouring classes found warm defenders among the most eminent theorists of the science of finance. " "In Thuringen," an eye-witness

${ }^{1}$ Nevertheless, as late as 1790 the French towns provided for public expenditure by the revenucs from the octrois, neither being able nor desiring to assess the rich with direct taxes. It was only under the pressure of popular revolt that this odious imposition was finally abolished.

${ }^{2}$ Fellmeth, Zur Lehre von der intcrnationalen Handelsbilanz, 1875, p. 111. Cucheval Clarigny, Finances dc la France, 1891, p. 40.

${ }^{3}$ See on this subject, Voclic, loc. cit., pp. 331, 55, 85, etc. Hoffmann, Dic Lehre von dcn Stcucrn, Bcrlin, 1840, p. 319. Hock Öffontliche Abgabcn und Schulden, Stuttgart, 1863, p. 222. Nalchus, Handbuch dor Finanzwissenschaft, Stuttgart, 1820, i., pp. 362-63. Gneist, Das heutigc cnglische Verwaltungs recht, Bcrlin, 1857, i., pp. 275, 308. Leroy-Beaulieu, Traité de la science des finances, 1883, i., p. 245. Lassalle, Dic indirccte Steucr und die Lage der arbeitenden Klasse, Chicago, 1863, p. 85 ff. 
said, "it is surprising to see the contributions that can be extorted from the poor and the indigent. The taxes are voted by the rich, who control far more votes than the poor, who dare not vote freely." 1

Economists extol equality of taxation and preach the dogma, but the bourgeoisie everywhere understands full well how to shift the larger part of the burden upon the poor by means of taxes upon the consumption of necessaries. Only a few years ago Chamberlain, the British minister of commerce, declared that in England the rich paid, on an average, 4.7 per cent. of their income in taxes, while the poor paid 7.9 per cent. of theirs. ${ }^{2}$ Even today the indirect taxcs of the United States assess necessities and exempt luxuries. In fact, the modern system of taxation, instead of being inspired hy principles of justice, conforms rather to the maxim of Saint Matthew (who in his former capacity of gatherer of the taxes was an authority on matters of finance). "Unto every one that hath shall be given, and he shall have abundance: but from him that hath not shall be taken away even that which he hath." 3

But in our opinion it would be a great mistake to regard this

'Sax, Die IJausindnstric in Thuringen, Jena, 1sis, ii., p. 58.

${ }^{2}$ Chamberlain's figures have been disputed, but not the underlying fact he brings to light. Sce on this point the licomomist of the 14 th and 15th of February, 1885. On the prevalenee of indirect taxes affecting the poor under the English financial system, see Cliffe lesslic, lissays in Political Ecomomy, London, 18ss, p. 407. In Italy, Pescatore has already taken issuc with the rich who oppose taxes on objects of luxury wishing to lay them upon anticles of primal necessity (Logica dill imposte, Turin, 1867, p. 196). But taxes up an articles of necessary consumption still predominate (Ricca Sitcrno, Sulle riforma delle impeste indirelte in Italie, extract from Finanzarclsiv, p. 38). "Indirect tases are the main resource of all modern butgets" Cerboni, Statistica comparata dit bilanci dei

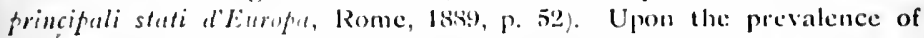
indirect taxes in our century, sec Clamangerau, Histoire de limprit en Fronce, Paris, 1867, i., xxy. He show's that the indirect tax, that in firance in 1839 amounted to $11.66 \mathrm{per}$ echt. of the revenue from direct suation, in 1863 gave 40353 per cent. of lase same (sce also \%orli, sistcmi fincunziari, Bologne, 1S\&5, p. 70).

"When we speak of the experses of governument, "we me:n, in very barge measure, that which is taken from the ginins of the people"

Gladstone, spech before the House of Commons, I6th April, 1863) 
financial animosity toward the people as exclusively the result of the avidity or caprice of the bourgeoisie. The disposition may be partly attributed to the auri sacra fames, but it is also partially the result of the law of survival of the capitalistic economy, which during an entire phase of its evolution requires the reduction of wages to a minimum. This also explains the indirect methods by which capital unconsciously endeavours to accomplish this result. During this period capital not only burdens the labourer with indirect taxes, but also shifts a large portion of the tributary charge upon small proprietors and independent artisans. The taxation of small capitalists is, indeed, rendered necessary by the law of the persistence of profits; for when population does not increase in the same proportion as capital, any augmentation of the latter that cannot be converted into unproductive capital is bound to raise wages and thus implicate profits. This result can, however, be avoided by expropriating the small capitalists, for they are thus converted into wage earners, and the resulting augmentation of the number of labourers, corresponding to the increase of capital, does away with the influence the increase of capital would otherwise have in raising wages. Thus, in so far as a tax upon small capital hastens its ruin, ${ }^{1}$ taxation is a powerful instrument for the preservation of profits.

In cases where it is impossible to tax the small capitalists, and where the imposition of heavy indirect burdens upon the labourers is unwise on account of the increasing impatience of the working classes and the probable reaction such taxes would excite among the masses, capital has to proceed in a very different way to reduce wages to the requisite minimum. It can only do so successfully by imposing taxes on profits, which, by retarding accumulation, contribute indirectly toward lowering wages, or at least prevent them from rising to a dangerous

${ }^{1}$ Mortara (I doveri della propricta fondiaria c la questione sociale, Rome, 1885 , ch. iv.) makes this point perfectly clear. See also Sonnino, $I$ coniadini in Sicilia, p. 307, et passim. Jäger̂, Die Agrarfrage der Gegenevart, 188:, iii., p. 107. Bertagnolli, Economia dell' agricoltura, 1886, pp. 23-26. Lexis (Gewerk-vereine und Untcrnehmerverbände in Frankreich, 1879, p. 87) endeavours to minimise the effect of taxation in wiping out small enterprises, but his remarks are not entirely convincing, 
point. At such times the taxation of profits is not only advantageous to the capitalists themselves hut even essential to their continued existence. Thus, for example, at a time when for some reason or other an augmentation of unproductive capital is impossible, the rise in wages (which would inevitably result from the increase of capital and thus jeopardise the existence of profit) can only be prevented by checking accumulation, and this can best be done by lowering the rate of profits. Hence this economic paradox, that the capitalistic class is compelled to favour any plan that tends to check the demand for labour; and among all such schemes none is more effective than a heavy tax upon income and capital.' Such was once the case in the United States. Even after a large number of the taxes introduced at the time of the war of the rebellion had become superfluous, all the tax-payers were not released, but only the less well-to-do. The taxes on the rich were thus left intact. This policy was pursued because it was recognised that so sudden an emancipation of capital would give too great an impetus to productive accumulation and thus raise wages. ${ }^{2}$ The real cause of such autotaxation remains a secret, however, even to the capitalists themselves. To them this exclusive or preponderant taxation of capital appears in the light of a principle of justice. It is, indeed, this unconscious tendency of the capitalistic class to tax itself that gives rise to the ideals of tributary equality, the ethics of finance and the proportionality of the sacrifice. In fact these ideals constitute the immediate motive impelling the capitalists to consent to an income tax, which is, in fact, an essential condition of the persistence of profits.

But a still more serious reason soon compels the capitalistic class to submit to taxation; namely, the reluction of wages to a minimum. This makes it impossible for the labourers to pay taxes, and, consequently, compels property, under pain of a

'This did not occur during the middle ages, however, for an increase in the reward of labour would not at that lime have endangered the persistence of eapitalistic revenue.

"Wells, "Recent Financial Experiences in the United States," in the Cobden Club Lissay's, ii., 1872, p. 496. 
chronic deficit in the budget, to support the tributary charge. The exclusive taxation of the bourgeoisie was made possible during the feudal period by the comparative prosperity of this class; but in our day a heavy taxation of the labouring class is out of the question on account of the working man's poverty. So long as wages are maintained above the minimum, they naturally bear the burden of taxation; but when wages are reduced to a minimum the capitalist understands that in taxing this form of wealth he is actually assessing profits. For this reason the previous efforts of the ruling class to shift the burden upon the masses suddenly cease. It is for this reason that, at a certain stage of modern economic development, we note the appearance and general spread of the plan to exempt the minimum necessary for subsistence from taxation. This is the reason why we find the reduction of wages accompanied by a gradual transition from indirect taxes, that are particularly hard upon the poor, to direct taxes that especially affect the rich. In France, for example, we note the first movement towards an income tax in 1725 , following the havoc created by Law's scheme. The taille and custom duties proving inadequate on account of the abject condition of the labourers and the poverty of the people, it was necessary to have recuurse to the tax of the 50th, worked out by the monlss of Paris. This tax was to be raised tor twelve years-in kind from the fruits of the soil and in money from all other kinds of revenue-and its product was to be devoted to paying off the public debt. But in spite of the end to which it was to be applied, this tax excited general indignation. The magistrates refused to enter it, and in order to make it effective the lsing was finally obliged to resort to lit de justice. ${ }^{1}$ This also accounts for the spectacle of the nobles and clergy of France renouncing their exemption from taxation in the Assemblies of Notables from 1787-1788. The same spectacle was repeated in Sicily in 1810. These sudden renouncements of privileges were but the result of the growing impossibility of confining taxation exclusively to the lower classes; for the bourgeoisie, by buying up offices, had already succeeded in exempting

${ }^{1}$ Bailly, Histoire financière de la France, Paris, 1839, ii., p. 110, 
themselves from the tax, and the labouring class, reduced to the last degree of poverty, was incapable of bearing the load. In England, at the very moment when capital was celebrating the reduction of wages to the minimum, Pitt proposed an income tax, and though the plan was at first opposed by the capitalist class, it triumphed in the end. Afterwards, when wages rose, the income tax was suppressed, and it was not definitely re-established until 1842, after wa:-es had again fallen to the minimum, and then only upon the cxpress statement of Robert Peel that the maximum limit of indirect taxation had already been reached, because the income of the popular classes was not susceptible of further taxation.2 In Germany the same phenomena were reproduced, and there, too, the

'See De Stourni's remarkable work, Les finances de l'ancicn régime et de la Rívolution, Paris, 1885, i., pp. 230, 237, etc. We should, however, make a note of De Gonel's renuark upon the facility with which the nobility subjected their own privileges to criticism and advocated their suppression. The poverty of the lirench labouring classes on the eve of the Revolution is vividly described by Taine (Les orig.nes de la France contemporaine, Parıs, 1576, i., pp. 176, 431, 507).

${ }^{2}$ The progressive income tax proposed hy Pitt under the stress of the antı-Napoleonic war was energetically opposed by Fox and Slueridan, both of whom denounced it as a violation of property rights, and it was not accepted by the English Parlianent until transfurmed into a tax on imports, which was soon after (1802) abolished on account of the opposition of the rich classes. It was re-established in the following year under the name of a property tax on account of grave financial difficulties. But this tax wats likewise abolished in 1816, and such was the aversion it aroused that ['allianent ordered the destruction of all the documents that had served to establish it. Rohert lecl afterwards iutroduced an income tax, hut he only succeded in hiving it passed by presenting it as a provisional measure. Gladstone also only succeded in reducing indirect taxes by allowing the tax to remain on articles that were most necessary to the lahourer, as, for cxample, beer. This concession was essential in order to gain the support of the rich classes for his project (Vocke, loce cil., pp. 87, 99. Pfeiffer, Startscinnahmon, Stuttgart, 1866 , ii., p. 2.15).

If one compares this bitter struggle over the introduction of the income tax with the ease with which l'atliaments voted the indirect taxes on articles of consumption affecting the poorer classes, it 1 ecomes still nore evident that financial policies are but the expression of properticd interests. 
introduction of the income tax, in May, 1851, corresponded with the reduction of wages to the minimum. ${ }^{1}$ In Italy, however, the abolition of the milling tax was only effected when agricultural wages were insufficient to support life.

The history of taxation thus presents a singular development. At the outset of the middle ages direct taxation of landed proprietors was the rule, on account of the poverty of the bourgeoisie class. During the second period the immunity of the feudal classes from direct taxation, together with the impossibility of shifting the whole burden upon the bourgeoisie (who were then not rich enough to bear it), resulted in the prevalence of indirect taxes. At the third phase the feudal classes were powerful enough to escape taxation entirely, while the increasing wealth of the bourgeoisie made it possible to shift the entire tributary charge upon their shoulders. These concurrent influences led to the diffusion of direct taxes among the bourgeoisie. At the fourth stage of development the dominance of the bourgeoisie and the existence of an imposable margin in the revenues of the poorer classes led to the reintroduction of indirect taxes which affected the working men. And since then the successive reductions of wages toward their minimum have made direct taxes once more the rule.

The preponderant taxation of the capitalistic class ${ }^{2}$ at a certain stage of our modern development is, therefore, in no way contradictory to the theory of the economic constitution of the State; for it simply results from the fact that it is impossible to burden the labouring classes any further after their wages have been reduced to a minimum. So true is this that the labourers are usually retaxed as soon as their wages rise. Thus several years ago duties on cereals were re-established in Europe as soon as wages rose, and all sorts of

${ }^{1}$ Indirect taxes were the rule in Prussia after the year 1806, but under the form of impots de classe, that were particularly grievous to the poor classes (Schmoller, Epochen, etc., pp. 91, 95).

${ }^{2}$ Alessio (Saggio sul sistema tributario in Italia, Turin, 1882, i., pp. 211, 215) while recognising that the dominant class is apt to throw the burden of taxation upon the subjugated class, also remarks that during the last fifteen years a sentiment in favour of the expediency of taxing themselves has taken root among the ruling classes. 
impositions came to be shifted once more upon the labourers.' But capital is not taxed simply with this end in view. Taxation of this kind is also in the interest of the capitalistic class as soon as profits have reached their minimum rate, because by retarding accumulation these taxes put off the periods of commercial crises. Taking this influence into account, an in. mediate solution suggests itself to several perplexing questions of finance. It explains, in the first place, why it is that with economic progress a transition occurs from the property tax to the income tax. The difference between these two forms of taxation is simply this: the former assesses unproductive wealth, while under the latter system it is exempt. The property tax consequently is in itself a stimulus to accumulation, while no such function pertains to the income tax. At a time when the rate of profits is considerably above the minimum, and when accumulation can proceed along its normal course, the property tax is preferred on account of its influence in stimulating accumulation. But when, by reason of the reduction of profits to a minimum, accumulation must be held within certain bounds in order not to arrive at ruinous excess, the income tax is preferable, simply because it accords no special encouragement to accumulation." From this point of view it is also easy to explain how it is that modern Parliaments, representing property and capital, are coming more and more to favour taxes on inheritance and progressive

'In the sessions of the Italian Chamber of the 21 st and 22nd of June, 1890, the minister Giolitti and M. Maggiorino Ferraris declared that in Italy the rich classes were comparatively little burdened, and that the mass of the taxes fell upon the poor. This naturally provoked an absurd reply from an enraged agrarian.

2 The expediency of limiting accumulation suggested by a reduction in the rate of protits, also explains the aversion that several economists (Lchr, for example, in the Zeitschrift fir Sthatstiss, 1877, p. 220 ff.) have toward exempting from taxation that part of the income which is the result of saving, even though an immunity of this kind affords the only way of avoiding double taxation. Thus are likewise to be explained the subtle distinctions made hy certain financiers with a view to denying the incontestable fact of such double taxation. Thus, Vocke, Dic Abgaben, etc., Stuttgart, 1887, p. 471. Bastable, Public Finance, London. 1892, p. 298. 
taxation. To understand this phenomenon we have only to remember that with economic progress there is a constant growth of disposable funds, and that when wealth of this kind is concentrated in the hands of large capitalists, it is especially apt to flow into ruinous speculations, and be swallowed up in financial failures. Now the inheritance tax is doubly efficacious in minimising the danger of such disasters, on the one hand because it takes from the tax-payers a portion of the capital which would otherwise be absorbed in speculation, and on the other hand because it leaves the rate of profits unaltered, and thus prevents the conversion of productive into unproductive capital, which would be the inevitable result of a fall in the rate of profits. lt is for this reason that the inheritance tax is much more suitable to a period of minimum profits than a progressive income tax, for the latter, by causing the rate of profits to sink below the minimum, leads to speculation. This also accounts for the increase and extension of inheritance taxes during periods when profits have reached a minimum, as, for example, in modern times and the decadent days of Rome. ${ }^{1}$

But after the economy has passed into its automatic phase, the progressive income tax becomes necessary on account of the reduction in the rate of profits. During the systematic period it is entirely different, as we have seen, for the heavy taxation of small capital is then necessary for the persistence of profits. But after the capitalistic economy has become automatic, progressive taxation becomes advantageous to large capital. This is true because small capital obtains a lower

${ }^{1}$ De Graziani's ingenious observations upon the economic nature of inheritance taxes do not explain why they are preferred to the progressive income tax. One can only understand it when one bears in mind that the former do not retard accumulation, while the latter has just this effect. It is true, Ricardo imagined both taxes had the same effect, and that both equally discouraged accumulation (Works, pp. 540 and 89), but his arguments are based on psychological factors of which it is impossible to determine the weight, and not upon economic grounds. $\mathrm{Had}$ he, on the contrary, perceived that the intensity of productive accumulation is in proportion to the rate of profits, he would at once have understood that inheritance taxes could not limit accumulation, simply because they do not diminish the rate of profits. 
rate of profits, and a proportional tax, which does not reduce the profits of large capital below the minimum, may still have this effect upon the profits of small capital. Should this reduction of profits then result in the conversion of small capital into unproductive capital, it would inevitably work an injury to large capital by provoking crises and disasters. It is, therefore, advantageous to large capital to substitute a progressive tax in the place of the proportional tax. Progressive taxation is consequently demanded in the interest of those whom it burdens

This necessity of subjecting large revenues to a tax that is more than proportional to their anount is the principal cause of a most important financial phenomenon, namely, the transition from a tax upon the net product to a tax on incomes. The continued reduction of the taxable margin in the hands of the poor and the labouring classes accounts for the transition from indirect to direct taxation, but it does not afford any reason why there should be a transition under the latter system from taxes on the net product to taxes on incomes. This latter transition can only be explained on the ground that taxes on the net product must, by their very nature, be proportional, and consequently cannot assess great fortunes at a higher rate. Hence when economic conditions render it advisable to levy a proportionately heavier tax upon the rich, it hecomes necessary to give up the tax on the net product, which is ncither supple nor elastic, and substitute an income tax which is by nature flexible and which can readily be adapted to the varying personal conditions of the different tax payers. But that which contributes still more efficaciously to the introduction of this peculiar and essentially modern form of direct taxation, is the necessity of reaching the incomes from unproductive capital and umpro. ductive labour. The tax upon the net product, assessing rent and profits exclusively, fails to reach the incomes derived from speculative or from intermediary capital, professional labour and the like. So long as unproductive capitil and unproductive labour are the objects of special favours on the prart of the State, the tax on the net product is usually preferred, because it does not reach the income from these sources. But the 
moment producers declare war upon these parasite incomes, and the favours of the State are withdrawn from these quarters, all the enormity of such a financial scheme is recognised, and it becomes necessary to introduce another system in order to assess these incomes that were formerly exempt. The new system finds its fulcrum in the income tax, which lifts the burden of taxation from its old real property basis, and allows it to rest henceforth upon the Prolean revenues derived from professional labour and speculative capital. Though it consents to burden large fortunes thus with a heavier load, the capitalistic state is nevertheless careful to alleviate the resulting inconvenience by refusing to regulate this income tax by objective standards based upon a technical valuation of the individual's possessions, and leaves the matter to a purely subjective criterion based upon declarations which allow a large part of the revenues to escape taxation. ${ }^{1}$

The aversion toward unproductive capital and the necessity of subjecting it to taxation explain still another financial institution, the tax on the transfer of property. This tax, irrational at the first glance and, in the eyes of a large number of financiers, without any logical basis, is really the outcome of the same desire to tax intermediary capital and other forms of unproductive wealth that cannot be reached even by the income tax. Hence the modern development of this new form of taxation. ${ }^{2}$

Important influences are also brought into play through the differentiation of the revenues, and particularly by their bipartition into agricultural and industrial incomes, into rent and profits. The effects of this schism are even more important

1 "In the State of New York, although wealth increased enormously from 1875 to 1885 , the personal wealth declared actually diminished" (Ely). We see from this the amount of confidence that can be placed in declarations. In Prussia it is calculated that the rich classes are only taxed upon half their real, income.

${ }^{2}$ See Vocke, Geschichte, p. 231 ff. Alessio, loc. cit., ch. i. Bastable, loc. cit., pp. 521-22. Wagner, Allgemeine Steucrlehre, pp. 432, $443 \mathrm{ff}$. In Italy, where unproductive capital is all-powerful, it succeeds more easily in escaping taxation, and the failure of the law upon the nullity of nonrecorded acts was due to the powerful opposition of speculative capital. 
than the phenomena we have thus far mentioned. When monopolised landed revenues find themselves in conflict with industrial revenues which are likewise monopolised, the former may prove powerful enough to cast a large part of the burden of taxation upon the latter. Many different countries offer examples of this during the medieval stage of their economic development. Thus in the United States, during the early part of this century, when political power was in the hands of the landed proprietors, the taxes hardly affected the soil at all, for the inhabitants of the towns bore practically all the public expenditure. In the Republic of Florence, also, in the sixteenth century, taxation weighed more heavily upon the inhabitants of the towns than upon the peasants. ${ }^{1}$ But still more renarkable are the effects of the contest between rent and profits. At such times and in those countries where rent predominates economically and politically it is invariably exempted from taxation. There are numerous examples of this. Thus in 1852 a proposition was brought forward in England to double the house tax and extend it to all houses whose rent exceeded $£ 10$; but the project was energetically combated by the inhabitants of the large cities, who as electors hastened to range themselves in opposition to the plan and succeeded finally in wrecking it." In 1860 the Lords opposed the abolition of the tax on mercantile paper proposed hy Gladstone, because the plan would have involved an augmentation of the charges on landed property. In Italy, likewise, the proposal to revise the property tax was defeated in the Senate (March, 1888), because, as is well linown, this body is largely composed of owners of huildings. On the other hand, the fact that the land owners possess a majority in the Chamber of Deputies was shown very elearly by their refusal to re-establish the tithes on landed property (Ilay, 1888). Even though rent thus refuses to drink of the bitter cup of taxation, it does not, however, object to favouring an alleviation of the taxes affecting labour, provided that the burden lifted from this base may be shifted upon capital and industry. Under

${ }^{1} C f$. Chevalier, Lettres sur l'Amerique dh Nord, 1836, ii., p. 265. Ely, loc. cit., p. 122. Canestrini, loc. cit., p. $3 \$ 3$.

${ }^{2}$ MacCulloch, loc. cit., p. 51. 
the Walpole ministry, for example, the Scotch Lords opposed indirect taxes and made the most of this opportunity to have capital assessed rather than labour. ${ }^{1}$ The alliance between the landed proprietors and the labourers in modern France has likewise resulted in the taxation of the capitalists. This only goes to show once more how the bipartition of the revenues always brings with it great advantages to the labourer. No less noteworthy are the facts that followed immediately upon the institution of the income tax in England. Landed proprietors whose income was more readily determinable, inveighed against the tax and accused the industrialists of fraudulently concealing their profits; while the industrialists, on their side, declaimed against the idle landlords and their realth. This struggle resulted in repeated revaluations of industrial revenues; and after it became evident that the incomes declared were regularly lower than the real incomes, the rate on industrial revenues was raised and the farmer's rate was correspondingly lowered. But a stiil more remarkable instance of the omnipotence of rent during a certain period of development is to be found in the history of the English tax on luxuries. "Real luxuries are rarely taxed," as Dühring has rightly observed, "because those who enjoy them control legis!ation." The landlords of England, nevertheless, favoured such taxes, and why were they then the exceptions? Because they lived during the greater part of the year in the country, and therefore did not object especially to taxes on luxuries which would affect the industrial classes of the towns almost exclusively. Thus Tory ministers were able to give an easy proof of their generosity by taxing the consumption of the rich. But as soon as the Whigs (the industrialists) came into power under Gladstone, the taxes on luxuries were abolished.?

The growing power of capital and its increasing prevalence over rent has its immediate effect upon the existing system of finance. It succeeds, indeed, in impairing the tributary immunity that rent has up to this enjoyed, by shifting a large

${ }^{1}$ Lccky, England in the Eighteenth Century, ii., p. 64.

${ }^{2}$ Bilinski, Dic Luxussteuer als Correctio der Einkommensteuer, Berlin, 1875, pp. 68.70 . 
part of the burden of taxation upon the landlords. The most notable example of this is to be found in the institution of the income tax in England. The growing power of the industrial class exerted increasing influence upon the distribution of this tax, and finally ended by assessing rent especially high; even to-day rent pays $17 \frac{1}{2}$ per cent. while profits only pay 8 per cent. of the tax. ${ }^{1}$ Not content with their success, the capitalists then desired to do away with the income tax entirely, and replace it with a tax upon rent. In 1853 Gladstone began his attack upon the income tax, which he proposed to abolish in 1860 . He maintained that the labourers were not so much benefited by freeing the products which they consumed from taxation as by freeing the capital that gave them employment; and in this way he prepared the way for the exemption of the industrialists from taxation. By then proclaiming the principle that industry ought to be freed and property assessed, he released lawyers, capitalists, etc., from the tax; and, by extending the inheritance tax to landed successions, he shifted new charges upon the soil." The Crimean War, and still more the reviving power of the landlords, rendered the abolition of the income tax impossible at this time. Nevertheless, in 1863, Gladstone again suggested the plan, and in 1874 he made a formal promise that if ever he were returned to power he would abolish the income tas, which was paid in so large a measure by the voters of his party, the industrialists. ${ }^{3}$ Three years before this Lowe had had the temerity to present a bill providing for still heavier burdens upon landed property. It thus came about that the landlords, who during the period of their ascendency had opposed the income tax, because it burdened them with a tributary charge, were now reduced to defending the tax, as it at least served as a means of shifting some of the burden upon

'Dudley-Baxter, The Taxation of the Unital Kingrdom, London, 1869, pp. $124,146$.

${ }^{2}$ Gladstone, Financial Statements, London, 1863, pp. 51-52.

${ }^{3}$ Lecky, loc. cit. This assertion of the English historian elicited a reply from Gladstone, and a polemic hetween the two writers followed. Buxton, loc. cit., ii., p. 165. 
industrial property. Finally, when rent regained political supremacy upon the formation of a Conservative ministry, all thought of abolishing the income tax was definitely abandoned. But though the landlords thus succeeded in recovering their political power and preventing the abolition of the tax, they were still not strong enough to alter the manner of assessment, and the tax continues to be especially unfavourable to the interests of landed property. Only to make the matter worse, the landed interests are also very seriously affected by local assessments which fall almost exclusively upon the revenues from the soil. It is very much the same in other countries. In Italy, for example, the direct taxes of the central government, the provinces and the communes all weigh very heavily upon landed possessions. Thus an alteration in the respective positions of the different kinds of revenue brings with it a parallel change in the distribution of the taxes; and the transfer of economic and political sovereignty from rent to profits involves a corresponding substitution of a preponderant tax on land-rent for the earlier heavy taxes on profits. ${ }^{2}$

"See on this subject the volume of the Cobden Club Essay's entitled, "Local Government and Taxation," pp. 153-176, 219 ff. Dudley-Baxter, loc. cit., pp. 37-39.

2 In a recent article Ricca-Salerno combats the conclusions here set forth touching the natural transition from a tax on profits to a tax on land-rent. He maintains, on the contrary, that the earlier form is a tax on rent. From this-but only at a later period-we pass to a tax on the income of capital, until the progressive decrease in the rate of profits finally renders it necessary to shift the greater part of the burden back again to rent (La trasformatione storica dci tributi in Europa ed in Ancrica. Nuova Antologia, February, 1891). But this objection rests upon an erroneous interpretation of the land-tax, established during the early centuries of our modern development. This tax, as we have already scen, assessed agricultural capital, not rent; and by raising the price of food-stuffs it fell entirely upon the consumer. It is besides singular to find this author classifying among the taxes on rent the taille, which as Ricardo has shown tended to raise rent. It is still more strange for him to offer the example of the taille in opposition to us, for our proposition only has to do with the wage economy where legal immunities are no longer possible; whereas the taille was an essentially feudal impost and presented a very marked instance of the nobles' immunity from taxation. 
No less important are the financial effects of the contest between productive and unproductive capital. During the systematic period, when the economic function of unproductive capital procures it special advantages, productive capital is compelled, in the interest of its own preservation, to exempt unproductive capital from taxation. To justify so peculiar an exemption, science, so called, then has to resort to the most ingenious subterfuges. It exaggerates the difficulty of taxing personal capital, whose manifold forms can, it thinks, easily escape the impost; it foresees the emigration of capital as the result of the tax laid upon it; it predicts and even announces the destruction of State credit when public funds are assessed; and so on. But when the function of unproductive capital, namely, its office of reducing the demand for labour and wages, has come to an end, and when profits former auxiliary has become its parasite, the subtleties of financial science are brushed aside, and profit and rent then begin to shift the burden of taxation upon personal capital (that was heretofore declared to be non-imposable), i.e., upon titles to the public debt, upon speculative capital, etc. This is done, as we have seen, by introducing the income tax and by laying taxes on the transmission of property. ${ }^{1}$

Finally the financial systen is also affected to a considerable degree by the struggles between revenue holders and unproductive labourers. The latter are successiul in escaping taxation in proportion as the dangers threatening property are great, and their aid is consequently more precious. It was thus that unproductive habotrers became all-powerful toward the decline of the Ronan Empire and succeeded in shifting the tributary charges accordingly upon the capitatists and land owners. And not very many years aso the fisc of the lingtom of Naples bore a heavy hand upon land-rent while it practically exempted the liberal professions - plyysicians, the architects, lawyers, etc., from all taxation. This was due to the fact that "those who practised these professions were in constant touch with

In Germany the tax on transactions of the Bonrse is upheld by the landed proprietors (Roscher, System, ir., p. 413). In the United Stales the large corporations are being subjected lo increasingly heavier tases. 
the people and therefore exercised a certain ascendency over them," and the Government, which was based upon property, was afraid of exciting these classes. Even to-day the professions that lend their powerful, though unconscious, aid to property are but little affected by taxation. But in proportion as the aversion toward unproductive labour increases, these professions become more and more heavily assessed through the income tax and other forms of imposts. 1

If capitalistic property exerts such considerable influences upon the normal course of finance, what can we say of its effects in exceptional periods, when war or some national crisis malses it necessary to suddenly increase public expenditure? It is at such times, indeed, that the enormous power of capital is especially manifest. Extraordinary taxes of this kind, by reason of their amount, can only be imposed to a limited extent upon the working classes, and the bourgeoisie categorically objects to every such project for meeting exceptional expenses by means of a tax. They prefer to have recourse to public loans; for by this means they benefit unproductive capital and at the same time shift the bulk of the charges necessary for the payment of interest, upon the poorer classes. Optimistic financiers have been inclined to glorify the thesis, now somewhat antiquated, that everything real is rational, and have adopted the most whimsical devices of logic to demonstrate the rationality of public debts. But facts brutally annul these chimerical notions and show quite clearly that the extension of this system of public loans is not due to the nature of things but simply to the omnipotent egoism of capital. Long ago in the Italian cities the growing ascendency of personal capital gave rise to the system of public loans and in its turn gained added impulse therefrom. On the eve of the great Revolution, Necker was obliged to resort to a public loan because the rich would not listen to any taxes. ${ }^{2}$ In England, at the time of her wars with France, the necessary expenses could, as Leone Levi and Cucheval-Clarigny clearly show, have perfectly well been met by taxing the rich, but the property owners put up an energetic

'Scialoja, I bilanci del regno de Napoli e degli Stati Sardi, Turin, 1858, p. $51 \mathrm{ff}$.

2 Vührer, loc. cit., i., p. 262. 
opposition and forced Pitt to resort to a loan which was contracted at ruinous rates. Not content with this success, the Bank of England also favoured the institution of a sinking fund, which resulted in immensely increasing the debt of the United Kingdom. Since then it has been the invariable policy of all Chancellors of the Exchequer, to whatever party they belong, to employ any surplus in the budget in the reduction of taxes rather than toward the liquidation of the public debt, because this is too dear to the dominant classes. Had Gladstone's provisions been followed, the expenses incurred in the Crimean War could have been met without resorting to a loan; but his successor three times had recourse to this expediency, for reasons that are easy to conjecture. We might devote a number of pages to citing instances of this kind, all of which go to show that public loans are by no means the result of unavoidable necessity, but rather a product of the self-interest of the capitalistic elass and one of the effects of the economic and political prevalence of unproductive capital. So true is this that the moment such prevalence ceases to exist and when unproductive capital is no longer the object of exceptional favours, Governments hasten to arrange for the extinction or the conversion of their debt, and seek henceforth to provide in other ways for exceptional financial needs. In this connection it is sufficient to recall the insurmountahle resistance the project for the conversion of the public deht of France met with in both Chambers in 1836, and the relative ease with which the conversion of the loan was effected in 1883 . This is enough to convince us of the close connection that exists between the fate of public debts and the power of personal capital.

After these inquiries into the actual development of financial institutions it is possible, perhaps, to trace the general theory of public finance. To this end we should look upon finance as a means of producing public services, and apply to this peculiar kind of merchandise the general laws of valuse, which vary under different economic systems according as competition between the various classes of producers is absolutely free or limited to any degree. Thus under the highest economic form the mixed 
association, where competition is absolutely free ${ }^{1}$ among producers of capital possessing different amounts of wealth, and between producers of capital and ordinary labourers, the amount of public expenditure is definitely determined by the number of public services required by the several producers. Not only is the total value of the public services thus definitely determined by their cost of production (since if it exceeded this amount producers of capital and ordinary labourers would themselves become producers of public services), but the value of the separate public services sold to different consumers is likewise determined by their respective costs, because if the producers of such services should endeavour to impose a higher price upon the better-to-do consumers the latter would themselves become producers of public seivices. Hence, under such conditions, the tax paid by each tax-payer is equal to the cost of the public services he consumes and the rate is proportional or progressive according as the cost of the public services demanded increases proportionately or more than proportionately to his income.

Leaving the free-land economy and passing to economic systems established upon the negation of this right, we find serious difficulties in the way of any such free competition among the several classes of producers, since the labourers can no longer convert themselves into capitalists or producers of public services, and as small capitalists can not readily become large capitalists. These obstacles to free competition involve a corresponding change in the law regulating the quantity and value of public services, and, as a result, the whole financial system undergoes a radical metamorphosis. The existence of a class that has no option in economic matters-that can neither compete with the privileged classes of society nor oppose their desires-makes it possible for the latter classes to sinift the heaviest burden of taxation upon the former. This may, and usually does, have a considerable influence on the number of public services demanded and the amount of public expenditure necessary to meet them. If the privileged classes had to pay for public services out of their

${ }^{1}$ See on this subject our Analisi, vol. i., chaps. i. and ii. 
own pockets, they would require but little; but when they know that most of these services are paid for by the subject classes they are naturally disposed to increase their demands. We can thus explain the logic of that principle, so dear to the science of finance, that in the public budget income must be adjusted to expenditure. This principle, apparently so contrary to every criterion of good administration and elementary common-sense, is rational enough when we consider that the public expenses are defrayed by one class while their amount is fixed by another class which is benefited thereby. Under such conditions public services are gratuitous to the class that establishes them, and financial legislation may thus extend in any direction according to the caprice of the legislators without causing any pecuniary sacrifice on their part. Neither the difficulty of providing for the public incone nor the burdens oi taxation sets any limit to public expenditure, because these factors have no weight with those who determine the disbursements. As a result, public expenditure is only limited by the will of the privileged classes, who also indirectly' determine the amount of public income. This explains the enormous expansion of public expenditure in the capitalistic economy. This increased expenditure stands in no possible relation to the collective needs of society; it is simply due to the fact that a large portion of the public services are gratuitously enjoyed by the privileged classes that determine them.

In the servile economy this excess in the amount of public services demanded over the amount necessary to society is determined arbitrarily by the privileged classes, but during the systematic period of the wage economy the surplus becomes in itself a condition essential to the continuance of profits. In fact, at this stage it is impossible for the capitalistic conomy to exist unless wages are reduced to a minimum ; and taxation sufficient to reduce the wages of the poorer classes to the required minimum is, therefore, the condition sine quat non of the continued existence of profits. Consequently the amount of wealth taken from the labouring classes is far more than enough to supply the collective needs of society, and public expenditure is artificially augmented. During the automatic 
period profits are no longer dependent for their existence upon the taxation of the labourer; but inasmuch as it is still possible to shift the burden of taxation upon the working man, whenever his wages happen to exceed the minimum, the inducement still continues to extend public expenditure irrationally. The tendency toward such extravagance is also accentuated during this period in another way. Floating capital comes to the surface and seeks profitable investment, which it cannot find in productive employment. An artificial expansion of public expenditure is therefore necessary in order to absorb this floating capital; for it would otherwise be employed in speculative enterprise and bring disaster to society. The necessity of unduly expanding public expenditure, which first bccame manifest during the systematic stage of economic growth, is thus enforced during the automatic period on very different grounds. ${ }^{1}$ But after this senseless expenditure has absorbed and exhausted the floating fund, and threatens next to absorb productive capital as well, a reaction is produced and a more or less lasting period of financial retrenchment follows.

The value of public services varies very much under the different forms of the capitalistic economy. In the slave economy, where there is no competition between the producers of wealth and the producers of public services, the total value of the services provided may exceed their cost, and, in addition to this, a portion of the price of the public services consumed by the large proprietors is paid for by the snall proprietors without the possibility of effective opposition on their part to such unjust taxation. The same thing is true of the serf economy, but with this important difference: the working men, if sufficiently well paid, can here bear a large part of the burden of taxation, and the taxes accordingly affect the labourersserfs and coloni, as well as the small proprietors. Under the wage economy, on the contrary, where competition prevails between the large capitalists and the producers of public services, the total value of services provided can never exceed their cost. A portion of the public services consumed by the large capitalists

${ }^{1}$ This modern cause of the expansion of public expenditure has already been remarked by John Stuart Mill, Leroy-Beaulieu and by many others. 
and by the producers of these services themselves is paid, however, by the small capitalists and the wage earners, as they, having no choice in the matter, cannot rebel against the prevailing system of taxation. An inverse progression of taxation proceeds from this, and an especially heavy charge is thus laid upon the needy classes. In much the same way a portion of the public services consumed by the holders of one kind of revenue is sometimes paid for by the holders of another kind of revenue possessing less power in the economic and political system. But when wages and the profits of small capital have been reduced to a minimum, neither the labourers nor the small capitalists can any longer be subjected to a tax. The roles are then inverted and a portion of the public services consumed by these classes is paid for by the large capitalists. As a result, taxation necessarily becomes progressive.

Such is the natural law of public finance. It is a law that is independent of the arbitrary action of individuals, and not to be overridden by bold reforms. But a certain field of action is still left open to the art of finance, whose mission will always remain important. In the first place, it belongs to the art of finance to make as much as possible of the bipartition of the revenues and the resulting legislative struggle, that both revenue forms (or at least one of the two) may be heavily taxed and the labouring class to that extent relieved. And even admitting the necessity of exempting the revenues at ecrtain periods from heavy taxation, the art of finance may still indicate the proper method of taxing the poorer classes so that the burden shall he as light as possible. Finally the atr of finance should develop a system of taxation that would reduce the difference between the amount taken from the tax-payer and the amount paid into the State treasury to the smalicst possible sum.

Not only do economic conditions thus imperatively determine the persons upon whom the taxes are to be imposed, but they also point out no less definitely the ohjects whence the State may draw its revenues. The art of finance finds itself hemned in in this direction also by the complexity of social relations. Why, for instance, did states so long provide for their public 
necessities from the products of their demesnes rather than by taxes? This was primarily due to the existence of free fertile lands which could be brought under cultivation without the application of capital. It was thus possible for the State to appropriate as much land as it desired and increase its resources by simply claiming fresh territory and setting new labourers to cultivate it. A tributary cause lay in the fertility of the lands under cultivation which made the extensive system of agriculture practised on State lands moderately profitable. ${ }^{1}$ After the free fertile lands were exhausted the State was no longer able to extend its demesnes unless it possessed the necessary capital to cultivate them, and capital could only be acquired by taxation. Hence the extension of the royal demesne of itself required the institution of a new form of public revenue and gave rise to the system of taxation. Beginning as the complement of the demesne revenues, this new institution came in time to form the real basis of modern finance. The transition was also hastened by a diminution in the natural productivity of the soil, which, on the one hand, rendered State agriculture more and more intolerable, and, on the other hand, by increasing land-rent, encouraged individuals to absorb the greater part of the State demesnes that they too might enjoy the blessings of "the unearned increment".

The system of taxation in its evolution was bound to follow the changes in the taxable objects. Thus in the Roman economy, when agriculture and industry were united on the oikos of the landed proprietors, taxes were assessed on the total income, both agricultural and industrial. But, when industry was separated from agriculture, taxes also split apart, and we note the assessment of special taxes upon merchant vessels, the lustralis collatio which affected the products of industry, and also the beginnings of taxes on personal capital.

'This is why the theorists of 'finance in the middle ages classified taxes among extraordinary dues, the demesnes, according to them, furnishing the ordinary revenues. Read, for example, Seckendorff, Teutscher Fïrstenstaat, Frankfort-on-Main, 1678, 448. This prevalence of revenues from domains over ordinary taxes in the total revenue of the State is reproduced in medern America (Ely, loc. cit., p. 60), 
In like manner at the beginning of the middle ages, before the towns had assumed an importance of thcir own and when buildings were but an appurtenance of the estate, the buildingtax formed part of the land-tax; but after the towns had become differentiated from the country, the tax on buildings also became separated from the tax on land; and finally when buildings became capitalised and the custom of renting grew up, the tax on buildings was transformed into a tax on leases. ${ }^{1}$ The English land-tax which in 1696 supplied 40 per cent. of the State revenues, under Walpole gave but 23 per cent., and to-day only represents 1 per cent., simply because personal wealth has relatively increased. The stamp on contracts and taxes on consumption were introduced in Holland after land (which was reclaimed with increasing difficulty from the sea) could no longer bear the burden of taxation. So long as laws prohibiting-usury were maintained, profits could not be taxed."

To summarise: at all times and in all countries it is economic conditions that determine, first, which classes nust be exempted from taxation and which are to bear the burden ; and, secondly, what objects are capable of assessment and advisable to tax. It is within these narrow limits, consequently, that the art of finance has to confine itself, if it desires to formulate systems and propose nocasures that shall place taxation on a really rational basis.

If our suppositions are correct, and if we are ready to admit that the financial system is rooted in cconomic conditions, we are forced to the conclusion that the modern science of finance is involved in serious error. Incleed, of all the social sciences finance has been least rcjuvenated by the life-hlood of historical research and the positive method. Instead of founding the system of taxation upon economic conditions-of which it is, after all, but the superstructurethe science of finance still holds fast to an anticuated phitosophy of law, and strives to deduce a system of taxation from certain

'Stein, Finanzwisscuschaft, 1878, ii., pp. $62-\$ 0$.

${ }^{2}$ Hock, loc. cit., pp. 117-18. In regard to the relative increase of the taxes on industry in proportion to the totil amount of the taxes in different states, see Malchus, loc. cil., i., p. 24.t. 
precepts of absolute justice. Yet, strange to say, the science is unable to determine whether this ideal principle of taxation demands a distribution of taxes according to the capacity to fu! , or according to the iquality of the sacrifice, or according to other criteria held by the various schools. ${ }^{1}$ But absolute justice does not exist, and modern science has shown that justice. lilie morality. varies with the several stages of social evolution. For this reason an eminent writer has attempted to found a system of taxation upon an historical concept of justice which is almittedly the product of a definite epoch and only applicable thereto." But eren this innoration cannot be regarded as adequate, since the justice, or the concept of justice, prevailing at any epoch consists, as we have seen, simply in that which redounds to the adrantage of the proprietary class. In fact, this salient maxim that the justice of any epoch enanates from the interests of the then dominant class. nowhere finds more perfect apflication than in the financial system. whose guiding frinciples are in reality but the dicta of an egoistic concept of justice corresponding to the interests of the propricary class. These principles are. in other words, the product of the economic conditions which determine the proper systen of tasation. Thus though justice proclaims the necessity of assessing every one according to his means, indirect taxes, which weigh preponderanty upon the poor. continue to prevail. And even when indiret tases are finally abolished, the change is in no wise due to some sudiden revelation of the precepts of justice. but simply follows upon a rejuction of wages. which makes it impossible for labour to bear the burden any longer. Nor was the eloquent argument in favour of frogressive taration enough o: itselt to cause the priaciple to triumph : but the moment cononic conditions made progressive tares distincty teneficial to the owning classes the reform was eftected spontareousiy.

Thus ins:as of coming down from the rebubus regions of absolute justice, as the science of Arane rould have it the

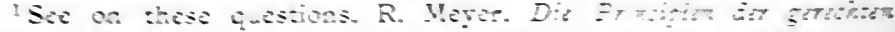

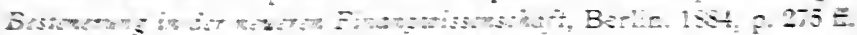

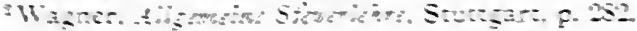


principles of taxations are really rooted in the sub-soil of economic conditions and proceed from the lower strata of social relations. The attempt to work out a theory of taxation and propose measures for its proper adjustment without first taking account of the organic composition of the State and the economic system that determines it, is, accordingly very much like trying to write a treatise on the hearing without troubling oneself to make a preliminary investigation of the auditory apparatus. It is into just such an error that the science of finance has fallen. Its analysis of the organic composition of the State is incomplete, and it takes no account of the compatibility of its doctrines with the organisation of social sovereignty. Hence the Utopian character of most financial theories. If the condition of the working men is moderately good and the bourgeoisie is able to shift the burden of taxation upon their shoulders, the science of finance proclaims the principle of equality of taxation. If wages are reduced to a minimum and the bourgeoisie is compelled to accede to the principles of equality of taxation, the theorists of finance then declare in favour of progressive taxation. Finally when profits have likewise been reduced to a minimum and progressive taxes have become a general necessity, financial science devotes eloquent pages to show that the State has a right to establish a "social" tax, effecting a profound change in the distribution of wealth. The theorists fail, however, to remark that such a tax would have to be voted by the legislature, or, in other words, by the rich classes in whose vital interests it is to prevent such a tax. ${ }^{1}$

1 In this connection it is worthy of remark that the older writers showed a much more exact conception of the nature of these phenomena than modern theorists do. For example, the already anticuated work of Lang on the history of German Hnances is inspiled from beginning to end with the idea that the sy-stem of taxition wat the necessary outcome of the military system, and that cvery modiflcation of the former was produced by change in the latter as an eficct by its cause (Lang. Entwicklung der deutschen Stcherverfossung, Berlin and Stettin, 1793). One may not be in accord with Lang's fundamental proposition, but one must at all events admit that he had a clear conception of the financial system since he regarded it as an organic product of social relations, 
The same visionary character applies to the more modern school of finance. These theorists do not set out from a principle of abstract justice in order to determine the nature of the financial constitution, but endeavour to analyse the laws which would govern public finance in a society of equals, where free competition existed among all classes of producers. This school undoubtedly marks an advance in scientific research, since it substitutes an analysis of the natural laws governing the incidence of taxation for the narrow empiricism which

instead of encleavouring to connect it with "prineiples of justice" or with the "will of Governments," or with the somewhat too plastic "conditions of intellectual development and civilisation". It is, indeed, the consciousness of this growing void in modern science (and the remarkable chapter-ii., 1, 2-in Wagner's Steuerlehre does not seem to me sufficient of itself to fill up the gap) that in my opinion explains the success of Rodbertus' observation, which, when reduced to plain language, may be summed up as follows: In order to lay a tax on industries there must first be industries. Undoubtedly the economic system determines the system of taxation by showing which class is politically dominant, and to whom therefore the decision in matters of finance is accorded.

The most noted of modern theorists, Wagner, falls. into flagrant contradictions on this matter; for he maintains the ability of the State to modify economic relations through taxation, and yet he admits that the development of the financial system has, up to the present, been the product of economic evolution (Stetterlehre, pp. 195-216). But if the relative dependence of financial institutions upon economic conditions be the law of all human history, why has this law suddenly ceased to operate at the present epoch; and how, in our day, can the State fashion a better system of taxation to suit itself ? This is an error similar to that made by the philosophcrs of the last century, who believed the past to have been ruled by caprice or chance and only the present by reason. This illusion is definitely maintained by Vocke in his last work (Die Abgaben, Stuttgart, 1887). It is only fair to remark, however, that among other adherents of the new school of finance, no less deserving of attention, this idea of the dependence of the financial system upon the economic constitution is beginning to prevail. Thus Schäffle (Grundsütze der Steuerpolitik, Tübingen, 1880, pp. 172-73) makes a point of the financial difficulties to which modern States are exposed on account of the disinclination of the proprictary classes, who control the Parliaments, to vote an increase of the taxes. Prudhomme, also, in his Théorie de l'impott, understood, though imperfectly, the economic basis of the financial system. 
wasted itself on a series of practical propositions that were often enough contradictory. It is perfectly evident, however, that the laws applicable to a hypothetical society of economically equal beings can have but little application to the various economic systems based upon the suppression of the free land where economic inequality is bound to prevait. It is clear, in other words, that any theory of finance elaborated on such premisses must, by its very nature, be visionary in character. Indeed its true character becomes only too manifest when we examine the doctrine as set forth by Sax, its most eminent and original representative. According to Sax public finance is simply the application of a certain anount of wealth to the satisfaction of public wants. The wcalth of each citizen is composed of a number of increments, the first of which satisfy his most pressing needs, and those that follow minister to wants that are continually declining in intensity. All that portion of his wealth which, if no public services were provided, would go to the satisfaction of individual desires of a lower intensity than his collective wants represents the amount he would be inclined to employ in the gratification of such social desires; or, in other words, the sum each citizen would be disposed to furnish the State. This sum ought then to increase with the augmentation of individual wealth; for the larger the patrimony of the individual and the greater his capability of applying his income to the satisfaction of wants of a low degree of intensity, the larger the number of increments available for the satisfaction of desires less intense than his public wants, and therefore the more considerable the sum he would be inclined to pay into the public treasury for the gratification of these collective wants. Let us suppose an individual whose possessions are represented by 10 to satisfy with the last three increments of his wealth wants of an intensity of $3,2,1$, respectively; while an individual whose wealth amounts to 5 satisfies with the last increment of his wealth a want of the intensity of 6 . If then the collective want felt by these two individuals be represented by 7 , it is evident that the latter individual would not be inclined to part with a single increment of his wealth for the gratification of this social desire, while the first-named individual would, on 
the contrary, be disposed to dispense with three increments of his wealth, because they in their totality only satisfy a want of the intensity of 6 , or a lower degree of utility than that of the collective want. In this way each individual spontaneously devotes to the satisfaction of his collective desires that amount of his wealth which has a somewhat lower utility to him than the collective want, and this amount naturally increases with the augmentation of his possessions. A harmonious satisfaction of the various individual and collective wants is thus secured, and therewith a sys'em of distribution congruous with the wealth of the various individuals and the varying degrees of intensity of their respective desires. Through the incidence of taxation the State merely sanctions and puts in the form of an imperative latw this natural distribution of wealth between the satisfaction of individual and collective wants. Or, to put it differently, it applies to collective wants the amount of wealth which would otherwise have been applied to the satisfaction of less intense individual desires. If the State should ever attempt to violate this normal rule and demand an amount of wealth from a group of tax-payers greater than they would be voluntarily disposed to devote to the satisfaction of collective desires, it would immediately provoke a reaction and render the continuance of such successive taxation impossible. ${ }^{1}$

We might offer in objection to this theory that it is absurd to try to justify the distribution of taxes on so arbitrary a principle as this calculation of the intensity of the wants satisfied by successive increments of individual wealth; for we can scarcely conceive how the legislator could be guided in his practical decisions by so nebulous a criterion. We might also add that the sum each man is disposed to employ in the satisfaction of his collective wants does not at all denote the normal value of public services (which are, on the contrary, necessarily determined by their cost of production), but simply marks the maximum limit this value may temporarily attain. But putting these objections aside, the fact still remains that so equitable a financial system could only apply to a society where free com. petition prevailed among the different classes of producers. It

¿Sax, Grundlegung der theoretischen Staatswirthschaft, Wien, 1888. 
would he entirely out of place in an economy based upon the suppression of free land where competition is lacling between labourers and capitalists and between small and large capitalists. Sax's theory recalls the idyllic financial conditions of former times, when the good town of Zurich was able to meet its expenses from the voluntary contributions deposited by its citizens in a sealed box. Under such circumstances one migite truly say that taxes represented the amount of wealth each citizen was disposed to apply to the accuisition of public services. But public finance has long since lost its idyllic character. In our day the labouring classes, being deprived of their liberty of choice, are compelled to submit to unjust taxation and renounce the satisfaction of painfully acute inclividual desires in order to pay for the social consumption of the rich. That is to say, the labourers have to devote to the State a far greater amount than they would spontaneously apply to the satisfaction of their collective wants. As a result the rich classes gratify their collective desires with a far smaller sum than they would voluntarily have devoted to this purpose.

It could not, indeed, be otherwise; for the most elementary logic shows us that it is impossible to establish a perfectly equitable financial system on the basis of an economic system essentially usurpatory in character. The theory we are oppos ing, therefore, conceals a logical contradiction. I say " con ceals," but this is a mere figure of speech. for as a matte" of fact the fallacy is perfectly apparent. It has not, indeed. escaped the attention of the more intelligent defender's of the theory in question. They ask with astonishment how it is that the injustice and exploitation prevailing in the economic wor:el do not enter into the financial system, which, according to their own theory, is but the outcome of economic conditions.' But this question (to which, by the way, they offer no reply) wou!d have been superfluous had these theorists only examined the real systems of finance prevailing in our capitalistic societies. instead of picturing the imaginaly financial system of some ideal State. They would then have been convinced that our present financial arrangements stand in no opposition to our

1 Wiescr, Der naturliche Werth, Vienna, 1889, p. 2335. 
economic system, but, on the contrary, run exactly parallel therewith; and that, far from eliminating the exploitation to be met with in the economic world, the methods of modern finance simply reproduce and accentuate the difficulty. ${ }^{1}$ In according their preference to the opposite method, these doctrinaires have only added another page to the already bulky volume of financial Utopias.

The visionary character of these financial theories is shown in a still stronger light when we come to examine the way in which they attempt to solve the controverted question as to whether taxation should be proportional or progressive. The old school of finance, which looks upon the tax as a burden imposed by the State, regards proportionality of sacrifice as the guiding principle of public finance. This principle requires that the units of utility taken from each tax-payer be proportional to the total utility of his income. This rule only leads to the institution of progressive taxation when the final utility ${ }^{2}$ of the tax-payer's income stands in inverse ratio to its total amount. If, in short, the utility of the last increment of his income (with which the tax is paid) varies inversely as the total income, a proportional rate by taking from cach tax payer an increasing number of units as their utility decreases requires from each an equal sacrifice of total utility. A proportional rate does not, in other words, increase the burden of taxation to correspond with the increase of total utility, and progressive taxation is, therefore, necessary. But when, on the contrary, the final

I It is to be remarked that Sax himself was the first to recognise that the egoism of the dominant class might place numcrous and serious obstacles in the way of his optimistic doctrine, but he regarded these impediments as mere "aberrations" of which the theoretical economist cannot take account. Such "aberrations" are, however, the result of a constantly active cause, and the product of an essential factor in economic evolution, namely, self-interest. It is thus the "aberrations" that follow the true cconomic law.

${ }^{2}$ By the expression final degrce of utility economists mean the utility of the last increment of the product demanded by the consumer. This final utility is naturally lower than that of the preceding increments, because the units successfully demanded usually afford a declining scale of utility to the consumer, 
utility of individual income declines at a rate less rapid than the increase of the income itself, progressive taxation is only rational on condition that the utility of the wealth taken by the proportional tax increases at a rate less rapid than the total utility of income.'

But this idea of the tax as a burden pure and simple is clearly erroneous; for the payment of the tax necessarily corresponds to a public service, of which it is supposed to be the equivalent. The moment we accept this latter concept of the $\operatorname{tax}$ (which Sax was the first to enunciate) we perceive at once that justice in matters of taxation does not demand proportionality but rather equality of sacrifice. It is no longer a question of making tax-payers bear a loss proportional to the utilities they possess, but rather a question of secing that all tax-payers give the same sum of subjective utilities in exchange for public services that are equally uscful to them. In order to conclude from these premisses in favour of progressive taxation, it is not enough that the final utility of the tax-payer's income stand in inverse ratio to its total amount; for even under such conditions a proportional rate would still conform to justice by requiring from each tax-payer the sacrifice of an equal subjective utility. To justify progressive taxation on these premisses it is necessary to suppose that the final atility of the tax-payer's income declines at a rate more rapid than the increase of its total amount, since only under such conditions would the amount taken from each tax-payer, which ought to correspond to the sacrifice of an equal subjective utility, be more than proportional to the total income possessed by each.

In this way Sax's theory restricts the operation of the progressive tax within very much narrower limits than the older science of finance. But in both cases, though in a different degrec, the argument offered by the two schools in favour of progressive taxation is of hut doubtful value. A principle so indiscernible and abstract as the declining utility of successive doses of income a principle which John Stuart

'See on this subject the profound work of Collen Stuart, Bijitrage tot de thearie der progressize Inkunsbilasting, s' Gratrenhatge, 1889. 
Mill rightly declared incapable of inspiring the work of legislation) is neither susceptible of any control nor open to any proof. The tax-payer has only to affirm that the final utility of his income declines at a rate less rapid than the increase of its total amount (and with certain limitations a mere assertion to this effect is enough for no one in a position to deny it) in order to prove the injustice and impossibility of the progressive tax. It is for this reason that the theories we are opposing can never succeed in affording a rational basis for progressive iaxation. ${ }^{1}$

Our own theory seems to us to avoid this difficulty; for instead of attempting to deduce progressive taxation from an indeterminable principle, it induces it from the actual fact that the cost of the public services required by the different taxpayers increases more rapidly than their wealth. This can occur in the mixed association because the successive increments of income may be applied to an ever increasing demand for public services. It can also happen in a capitalistic economy, when small incomes and wages, having become

${ }^{1}$ In a recent very remarkable work (Dic Progressivsteuer; extract from the Zcitschrift für Volkszirtschaft, 1892) Sax admirably exposes all the weak points of the theory which attempts to deduce progressive taxation from the principle of proportionality of sacritice. He shows that it is impossible to measure the decline in the utility of successive increments of revenue, and consequently to determine whether the rate of decline be such as to justify progressive taxation. But, a thing scarcely to be believed, he doss not seem to perceive that his criticisn affects his own theory with still greater force. From the logic of the theory which looks upon the tax as a sacrifice, progressive taxation is rational even though the final utility of the income diminishes at a rate less rapid than the increase of the income itself, provided it decline within certain limits. We can conceive of a number of reasons for a decline in the final utility of the income which would be compatible with a progressive tax. The legislator is thus a!lowed a certain latitude, and a sma!ler opportunity of resistance is open to the tax-payer. But a doctrine which only justifies a progressive tax when the final utility of the income declines more than proporticnatcly to the augmentation of the total income must always leave the tax-payer free to contest the existence of such conditions in his concrete case, and consequently allow him to deny the legitimacy of the progression. And the remarks gratuitously added by Sax at the close of his article in no wise suffice to dispel the contradiction. 
insufficient for the purpose, can no longer be app!:ed at all (or only appiied to an insigniflcant extent) to the acquisition of public services; with the result that a part of the necessary public services consumed by the small capitalists and the wage earners must be paid for by the large proprietors. Besides, our doctrine suggests a solution of the vexed question regarding the limits of progressive taxation, and offers the soundes: criticism upon the widespread opinion that the nature of the progression is indefinite and that its tendency is toward the confiscation of large incomes. There is no foundation for this sophism when we reflect that the very function of the progressive tax is essentially capitalistic, and that it is in reality advantageous to the class that institutes and maintains it. Inasmuch as the aim of progressive taxation is to prevent the profits on small capital and the wages of labour from falling below the minimum, the limits of such progression are exactly determined by that portion of the proportional tax which falls upon the profits of small capital and the wages of labour and ¿epresses one or the other below the minimum rate. $U_{p}$ to this point the class of large capitalists are willing to submit to a differential rate, and it is, consequently, just to this point that progressive taxation can go. The problem of progressive taxation is thus easily and exactly resolved when we bear in mind that the tax itself is the necessary outcome of the conditions surrounding the distrihution of wealth, and cease to attempt to laboriously deduce the system from some metaphysical principle of justice and utility.

\section{1.-Doninstic Politics.}

Still clearer evidence of this great law that political power is constantly being directed toward guaranteeing and augmenting the revenues is to be found in the domain of domestic politics. It is, indeed, through legislation primarily that sovereignty is expressed. From our remarks upon the capitalistic foundations of the law it has already become sufficiently clear with what partiality the State acts toward proprietors. Passing on now from legislation that has become crystallised into codes to 
the living and progressive legislation of present day legislatures, the spectacle presented is in no wise different. The dominant character of modern Parliaments-as also of the legislative assemblies of former times-stands in marked opposition to the interests of the labouring classes, except when social legislation is induced by a temporary conflict between the two revenue factions or a passing alliance of one of the factions with the working men.

If proprietors are sometimes reformers, it is only because it is in their own interest to be so. Alison's words: "Given the Toryism of a landed proprietor, how many years with no rents would it take to make him a radical reformer?" find constant application. Thus the present agrarian crisis is forcing a large number of British land owners to demand radical innovations - for example the abolition of the right of primogeniturein order to do away with existing obstacles to agricultural production. In like manner the long agricultural depression of 1829-30 led to the Reform Bill of 1831, which was passed by a Parliament of land owners. ${ }^{1}$ But beyond these exceptional cases, revenue is the enemy of all social reform. Thus in Italy, Parliament (especially since it has come to be elected by the extended suffrage) follows a distinctly capitalistic policy, refusing to legislate any matter tending to benefit the poorer classes, even though the question turn on the comparatively innocent proposition of a law to regulate strilies. But with marvellous facility the Italian Parliament multiplies idle discussions, passes laws, either utterly useless or of imperceptible importance, attempts reforms in administration, legislates in regard to the number of ministers, amends penal and judicial laws-all in order to avoid the danger of touching upon the social problem. $^{2}$ The Austrian Parliament, after many evasions, has finally allowed the proposition for working.

${ }^{1}$ Patterson, The New Golden Age, London, 1882, ii., p. 110.

2 Morcover, whenever proposals that are in any way beneficial to the poor elasses are presented in the Italian Parliament, they are invariably rejected. The Chamber, for instance, rcjected the proposal of a law regarding strikes, and succeeded in making a farce of the law concerning the protection of labour. 
men's assemblies to drop. ${ }^{1}$ In France an impartial writer pictures the condition of affairs in these words: "In our Republican Parliament no social question is seriously broached. Politics pure and simple rule and predominate there. They discuss the revision of the Constitution, the prerogatives of the Senate and Clericalism; they dispute with the monarchists; they expect marvels of the separation of powers; but they do not touch upon the pressing social problems which are presenting themselves with increasing pertinacity. It is not that Parliament ignores the gravity of these questions; it is simply powerless to solve the least of them." 2

In Europe where insensate military expenditure burdens the budgets so enormously, the Parliaments of the several countries, despite their social inaction, still find a large field of legislative activity in arranging financial matters. In America, however, on account of the inexhaustible fertility of the country and the moderate public expenditure necessary, the financial problem has not yet reached threatening proportions, and there is a void opening up before legislative activity. The legislative function is, in fact, reduced to so narrow limits that the State legislatures only meet at long intervals, sometimes not more than once in two years, and these infrequent sessions are strictly limited in duration. The laws discussed and voted upon in these short sessions are few in number and of mediocre importance. For the most part they are private bills, of advantage only to individual capitalists or the monopoly

${ }^{3}$ The history of this project of establishing working men's assemblies in Austria is very interesting and furnishes fresl proof of our assertions. The flrst proposition to this effect, formulated by the l:tbourers in 1872 , was rejected by Count Taafle, and only taken up again with many modifications by a Parliamentary Commission, which skilfully avoided setting a date when the proposition should talie elfect and thus practi. cally rejected it. Twelce years later the proposition was again presented-and why? Because the progeressive party (the capitalists) recognised the impossibility of overcoming the clerico feudal party (the landed proprietors) unless they showed some sympathy toward the labourers. But after the progressive parly had used the plan as a political instrument, it took good carce to prevent its success, and actually faroured the abandomment of the secheme.

${ }^{2}$ Maurice, Riforme agrate it misive on lirutit, IS87, p. 52. 
companies that flourish so extensively in the United States. ${ }^{1}$ These capitalistic legislatures are careful not to take any action on measures to ameliorate the lot of the working man, whose condition, even in the New World, is day by day growing more serious.

Administration likewise corresponds in character to the essentially capitalistic nature of legislation. The first effect that capital has upon administration is to create an enormous number of useless offices which render the administrative machinery of modern States so slow and cumbrous. To what can we attribute this phenomenon? During the middle ages the creation of superfluous offices was an indirect form of public loan, and we can readily understand how States might have to resort to such methods when their finances were in a critical condition. But in our day, when offices are granted ${ }^{2}$ and not sold, a very different cause leads to their undue multiplication. At the present time the creation of public employments is an excellent method of maintaining an army of unproductive labourers at the expense of the mass of the tax-payers; and also a means of completing the income of certain proprietors who, in the capacity of employees, are thus able to write additional revenues into the margins of the budget. ${ }^{3}$ The State in this way becomes a powerful agent in the redistribution of wealth, deducting a considerable amount from producers and transferring it gratuitously to non-producers, i.e., to proprietors and unproductive labourers. This redistribution, which in the supposed case demands at least an appearance of employment on the part of the classes so favoured, is often effected in

${ }^{1}$ Bryce, loc. cit., ii., p. $186 \mathrm{ff}$.

${ }^{2}$ In the United States the sale of offices is still practised, not, however, by the State but through the Rings. This simply results in distributing the funds taken from contributors among a larger number of unproductive labourers. The greater number of certain elasses of unproductive labourers in the United States is explained by the necessity of making up the lack of other kinds of unproductive labourers resulting from the absence of a military organisation.

${ }^{3}$ See the observations and interesting facts brought to light by De Molinari, in his L'évolution pölitique et la révolution, Paris, 1884, pp. 318, 455 , etc. 
a more flagrantly gratuitous manner. Thus the State may actually distribute a portion of the public revenues among its parasites; that is to say, among those who compose the State, namely, the members of the proprietary class.

The relation existing between the reventes and the administrative system naturally varies according to differences in the structure, the amount and the development of the income. In countries where the revenues are large, and where they can go on increasing, and attain their full development of themselves, l.e only demand upon social administration is not to place obstacles in the way of such development, and not to oppose their more or less legitimate methods of expansion, but allow them to organise every institution which can in any way favour their growth. Wherever, on the contrary, either the incomplete development of productive forces, or their declining activity, hinders the growth of the revenues, and when they cannot rely upon natural economic conditions to encourage their expansion, administration (and legislation likewise) is called upon to add new wealth by the aid of public authority. Public administration is in such cases converted into a suction pump to draw off wealth from the tax-payers and divert it into the profits of property. We see this process going on every day in a number of civilised States, where a part of the public moneys, instead of being applied to the production of public services useful to the proprietary classes, is handed over directly to the revenue-holders, in order to make up a deficiency in their incomes. It is useless to dwell upon this wellknown fact by giving pertinent examples; we simply desire to call attention to a practical conclusion that has resulted from this interesting phenomenon of contemporary politics. Whether the taking-over by the State of certain public functions that can he equally well performed by private parties is beneficial or not, depends upon what use the revenues make of public ad. ministration for the acquisition of wealth. Giving over certain monopoly enterprises, like banks and railway companies, to the State is undoubtedly advantageous when it takes out of the hands of private capital undertakings in which monopoly is bound to prevail and adds the profits to society. But when, 
on the contrary, the State is simply an instrument for expanding and integrating private income, and when the public revenues go to swell the pockets of proprietors, the attribution of new functions to the State is dangerous; for it simply adds a new base of supplies and a fresh source of nourishment to the equivocal and dishonest partnership already established between the revenues and social administration. Under such conditions the State is simply a joint-stock company in disguise, and the worst of all stock companies, because the mask under which it is concealed, and its own eminent position, allows it to act with impunity, and renders it particularly dangerous. These considerations, upon which we shall not insist any further, help us to understand the diversity of opinion that exists in different countries in regard to the absorption of public enterprises by the State, why the policy is regarded with favour in Germany, and why such an aversion to the plan prevails in Italy. Our remarks also go to prove-if further proof is necessary-that the economic doctrine of politics is not confined exclusively to theory, but also goes far toward simplifying practical legislation.

Beyond these more general influences capitalistic property also exercises its tyranny in all spheres of social administration. Every one, indeed, must be aware that administration is inspired almost exclusively in the interests of the rich classes, and that public expenditures are for the most part made with a view to favouring this small group. This is especially true of the provisions for instruction. Adam Smith, as we know, urged that the State meet the expenses of instruction for the poor, and leave the rich to provide for themselves; but modern States pursue the opposite plan. They devote enormous sums to classical and higher education of peculiar advantage to the bourgeoisie, but they strangely neglect the education of the masses. It is also perfectly evident that the outlay for the encouragement of the arts, for the military organisation, for public works, ${ }^{1}$ and for civil justice, all turn to the exclusive

1 We are indebted to Villari for some startling revelations on this subject (Nuovi tormenti e nuovi tormenteti-Nuova Antologia, 15th December, 1890). The municipality of Naples spent three millions for the 
advantage of the capitalist class. ${ }^{1}$ The monopoly of political power that the revenue-holders enjoy is no less manifest in the administration of those particular functions which are supposed, theoretically, to correspond to the interests of all social classes ; for, in practice at least, these offices arc performed by the State with marked partiality toward the proprietary class. Thus wealth's partial exemption from military service is but the result of its political preponderance The severity that juries usually apply to crimes against property, standing in such marked contrast to their habitual indulgence for crimes against the person," also reveals the bourgeoisie's influence upon judicial administration. Finally, the capitalist class is to a large extent exempt from punishment ; for as the fablist has said:-

Selon que vous screz puissant ou misćrable,

Les jugements de cour vous rendront blanc ou noir."

And even as there is a criminal code for the rich and another for the poor, so there are capitalistic penalties and penalties for

Galerie Humbert 1. The 100 millions voted by Parliament to Naples were all spent in embellishing existing structures and in building houses for the rich; and no means were found of spending any sum on houses suitable for the poor. In this way the poor have beendriven out of their hovels in the course of their demolition, and are unable to find other houses in which to instal themselves, because those which have been constructed for their use are far from the places of their labour and trade. The result is that they must either sleep in the open air or else take rooms in the houses recently construeted for the better-to-do, where they have to cramp themselves for roon on account of the excessive prices charged for rent.

'The fact that Zorli (Tcoria psicolngica della finanza publica, 1890) brings against me, namely, that capital would be obliged to tax itself in order to help the poor and unemployed, in no way contradicts what has been said in the text, because it is in capital's own interest to assure a means of existence to this outcast class which molesuolu fames might drive to terrible violence.

"Messedaglia, Le slatistiche criminali dell' imferio Austriaco, Venice, 1867, p. 117, in note. The purcly economic claracter of this fact does not seem to be eontroverted by the doubtful remarls of this illustrious writer. See also Ferri, Studi sullit criminalita in Francia, Rome, 1881, p. 35.

- La Fontnine, Fablis, liv. viii., 1. 
the proletarians. ${ }^{1}$ All these different phenomena, and others that might be mentioned, are but manifestations of the political prevalence of the class that predominates economically.

\section{I1.-Foreign Politics.}

Lcss evident, perhaps, but of equal importance, are the influences exerted by the revenues upon the foreign policy of a country, which is constantly being adapted to suit their interests. We have already had proof of this in the way that foreign politics follow the general variations of the different forms of revenue. In slave societies, for example, where the owning classes are freed from the sordid cares of accumulation, the plan of foreign politics is adapted to satisfy the land owners' thirst for glory and power, rather than their vulgar economic interests. This striking characteristic of the politics of slavery is familiar to those who have made any study of colonial development. So long as slavery prevails pecuniary interests are sacrificed to the desire of possessing political ascendency. We find a striking illustration of this in the desire of the Southern States to annex the island of Cuba. The annexation would have virtually ruined the planters of Louisiana, Florida and Texas, and acted prejudicially to the Union from every point of view save that of political power. Though the plan was not crowned with success, the mere fact of its having been suggested shows very clearly that the slave owners were

${ }^{1}$ In November, 1887, a Nilan jury acquitted Count P-, who was guilty of homicide, while a Savone jury condemned a certain coal-heaver, Firpo, to fifteen years' forced labour because he inflicted a wound upon another coal-heaver that fiftecn days would heal. The public concludes : the law is equally severc upon all miserablc wretches! An cminent personage assures us that in Italy rich prisoners are liberated after three or four months of imprisonment. Henry George said that if a man wished to kill another man in the United States he could do so without difficulty. He could give himseli up afterwards as a prisoner and with money he could readily obtain a decree of pardon (loc. cit., p. 384). A judge in one of the Western States made it a rule to acquit all well-to-do assassins, and he only gave up the plan when he was shown that such indulgence toward homicides, by discouraging immigration, lowered the valuc of landed property (Bryce, loc. cit., iii., p. 647). 
dominated less by a desire of gain than by political ambition, and that their sensibility in regard to this matter of political power was enough to cause them to make serious sacrifices to attain their end. The prevalence of this political concept exercised a very unfavourable influence upon the liberty of action of the several States. Thus when the question of the admission of Missouri came up in 1820, the slave States of the Gulf, in opposition to their pecuniary interests, joined with Virginia in voting for the admission of the new State. The admission of Missouri was certainly advantageous to the States that had slaves to sell-and among these was Virginia-for it increased the demand for their product; but it was injurious to the States that purchased slaves for use, becausc it augmented the number of competitors on the marlict. This compact alliance among slave owners shows thus how the ideas of political control predominated in the Southern States over mere private interests. It was politics again which occasioned the rabid demand for the extension of slavery into the tempcrate zone, and urged Texas, against her own interests, to co-operate so earnestly in the efforts to saddle slavery upon Kansas. ${ }^{1}$ The slave owners, thereforc, justified perfectly Aristotle's definition - which is precisely applicable to the slave societythat man is by nature a political animal.

Under the wage economy, on the contrary, the capitalist is tied down by the cares of production and accumulution, and, on this account, his political horizon is more limited. With this change in the ends and aims of the dominant class, politics are also transformed in character. "In our day," Pompae remarked, "commerce is the basis of politics." Thus in place of the grand and lofty ideas that dictated the policies of the ancient States, whose citizens were strangers to economic cares, there has succeded a form of politics that is meanly inspired by the economic interests of parsimonious accumulators of stock, whose end is to exploit the productive forces of the nation to the utmost. It is in this vein that Sydney Snith expresses himself in his vivid and original style: "Were Cxsar," said he, "to revisit the earth, the rate of cxchange ${ }^{2}$ Weston, Progress of Stazery in the United States, Washington, 1857, p. 35. 
would be of more importance than his commentaries, the Rothschilds would open and close the temple of Janus, Thomas Baring would command the 10th Legion, and his soldiers could march to battle with the cry: 'Coupons et Omnium, stocks and Cæsar!'"

The influences excrted by the revenues upon external politics will appear much more clearly after we have examined the many forms forcign politics have already assumed. Turning our attention first to the bistory of alliances, we shall discover that it is very often an underlying economic cause which determines their course. The history of Basel throws considerable light on this subject, and shows us that the alliances contracted by the bishop princes of this town were always determined by the exigencies of commercial politics. A painstaking historian says in this connection: "When we read that the Bishop Burchard de Hasenbourg obtained Buchogan in 1080 , a glance at the map shows us that he thereby secured the two passes of Havenstein and of the Aaar into Olten, giving him access to the great Swiss road which furnished Basel a means of communication with the Alps. The long struggle that the bishop maintained for possession of the cloister of Pfäfer appears in an entirely new light when we reflect that this cloister afforded the prelate an opportunity to make use of the Septimanian road. The bishop also obtained the passes of the Jura from the king as a point d'appui to the Septimanian road, and this shows that all his efforts were directed toward making his commerce profitable. The importance of these gitits reveals to us the price of the bishop's imperial policy. His desire to secure control of the Alpine passes, so essential to his commercial success, made Burchard one of the most faithful acolytes of the Emperor Henry IV. It was his craving for wealth that brought him to the Diet of Worms. It was his conmercial spirit again that caused him to take part in the deposition of Gregory VII., that made him range himself with those who were chosen to carry the decree to the Lombard bishops, and forced him to accompany Henry IV. to Canossa and oppose the emperor's rival. The greater the economic significance of these gifts granted to the prelate by 
the emperor, so much the more does the bishop's imperial policy assume the character of a link in the chain of his commercial projects." A rapid examination of the commcrcial relations existing between England and Flanders in the middle ages reveals the economic basis of this alliance as well. English wool was largely exported to Flanders, and it was consequently indispensable for England to maintain friendly relations with the Flemish towns, which formed the principal market for her most important product. For this reason the English sovereigns devoted every effort to maintaining this feeling of amity, and never undertook a war without first proving the Flemish alliance. This was especially necessary as the war expenses were usually met by a special tax on wool, and this tax, being paid in kind, had finally to be redecmed by exportation of the product to Flanders. ${ }^{2}$ To take another cxample: Geneva broke away from France and formed an alliance with Charles $V$. because the emperor had contracted a loan with Geneva bankers; and analogous reasons brought about the alliance between Geneva and France in the eighteenth century.

Many other equally convincing instances could be added; but numerous as they are, we cannot conclude that all political alliances are contracted for economic reasons. It may, indecd, happen when two nations enter into a political alliance that one proposes to reap conmercial benefits, while the other is actuated by a totally different impulse, either seeking to obtain some political advantage or hoping, by making commercial concessions, to augment its own power. It frequently happens that both nations scek a military rather than a purcly commercial end, and often such alliances, by occasioning real economic loss, actually sacrifice the commercial end in order to secure political advantages. ${ }^{3}$ But the loss is alway's com-

${ }^{1}$ Geering, Handel und Industrie der Stalt Basel, Basel, 1886. Sec also Fahrbuth fïr Gesetzgebung, 1887, pp. $1121-22$.

${ }^{2}$ Giblins, Industrial History of Engltumd, 1.ondon, 1888, pp. 48.49.

${ }^{3}$ We have an example of this in the present alliance between taly and Germany; an alliance which causes Haly serious injuries hy afford. ing opportunity for economic reprisats on the part of France, hut which is imposed by the necessity of defending our political integrity against the assaults of a power that is essentially military, on account of the fact that landed property is there predominant. 
paratively slight, because the commercial system is a very subordinate factor in the economic prosperity of a people. And whether this be the case or not, the economic influences thus driven out through the door usually return through the window, because the very military policy which lies at the root of these bellicose alliances is itself the outcome of the existing revenue system, and its real end is to augment national wealth.

The structure of the revenues has another very marked influence upon the constitution of society which we have not yet set forth. So long as the revenues were derived from slavery or serfdom, their enjoyment involved no process of accumulation on the part of the proprietor. Under these economic systems the function of accumulation was given over to the slaves and serfs, and force became the only means of acquisition left open to free man. This state of economic inaction to which the proprietary classes were condemned, together with the preference which the morals of the day accorded to conquest over accumulation, compelled the proprietors to look to war as the best means of increasing their revenues. And for this purpose they found a ready instrument at hand in the military organisation necessary to maintain servile labour in subjection. During its earlier stages, capitalistic society is militant in character by very reason of its economic structure, and this explains why war has so long remained a normal institution of humanity and proved so excellent a means of increasing national wealth. In primitive ages wars were only undertaken to conquer the products of neighbouring tribes. According to the most recent researches, the earliest form of exchange was simply mitigated pillage, and even in its historical form it bears the imprint of its origin. Primitive exchange was effected with arms in the hand, which were only laid down during the moment of barter and then immediately taken up again. ${ }^{k}$ Even in a less remote age we

${ }^{1}$ Sieber, loc. cit., p. 371. This contradicts the opinion of those who would derive exchange from the gift, and also Adam Smith's idea that it arose from man's natural instinct to truck and barter. 
frequently come upon wars that were provoked by economic causes. As an bistorian has said: "One of the most pressing motives of international warfare has been the acquisition of mines and the treasure accumulated in the temples of the gods and the palaces of the rich. The Romans were urged to undertake the two Punic wars by their desire of possessing the precious metals that the Carthaginians acquired from the mines of Spain, Sicily, Sardinia and Corsica. Alexander the Great by his invasion of Persia and India conquered a treasure amounting to fifty million pounds. ${ }^{1}$ But these phenomena showed themselves in a much more remarkable manner in feudal society, where the revenue-holders, completely divorced from the cares of accumulation, sought to increase their fortunes on the field of battle. Hence the incessant wars which cast so sinister a light upon the middle ages, spreading out in an ever-widening circle, between town and town, vassal and vassal, State and State, and finally between the West and the East.

This progressive extension of the wars of the middle ages was comnected with underlying cconomic causes which must now be examined. Property obtained by war, like property gained through accumulation, is subject to the law of diminishing returns. Fratricidal wars, constituting the most marlied characteristic of this form of social organisation, dry up the very fountain sources of production and gradually exhaust the wealth to be derived from such forms of usurpation. At the same time, the destruction of petty despots by the great diminishes the number of the adversaries engaged, and lessens the frequency and probahility of such internecine struggles. Hence the occasions for armed conflict between the proprietors of a certain region gradually diminish as the revenues derived from the servile system attain their normal derelopment. Thus sooner or later the moment is hound to arrive when the activity of the owning classes can no longer find an outlet in intestine broils and is reduced to a forced repose. It is then that the militant energy of the proprictors, eager for action, 
is apt to seek employment beyond the border. ${ }^{1}$ And just as the proprietors of our day, who gain their wealth by accumulation, are apt to embark on foreign ventures, colonial schemes and commercial enterprises of the most hazardous kind when they can no longer find remunerative employment for their capital at home, so in like manner the conqueror proprietors of old embarked upon distant wars and mad military enterprises when their national aims were checked by a diminution of production and a falling off in the number of proprietors resulting from their former conquests.

The crusades offer a typical example of such enterprises. No more surprising scene is to be found in all history than this religious enthusiasm which seized upon the different nations of Europe at the same moment and made them sacrifice their blood and the flower of their fortunes in the purstiit of a mad ideal. If we ask the superficial historian the cause of this remarliable phenomenon, we shall find it attributed to the eloquence of Peter the Hermit, or the marvellous power of the Faith; and such, indeed, are the first explanations that occur to us. But science affords us quite a different explanation. Indeed, the very raison d'être of science lies in the fact that the explanation of phenomena elaborated from our consciousness differs radically from the things as they really are. It is the exclusive task of science to substitute a deeper interpretation of things for the necessarily superficial and fallacious explanations afforded by our consciousness. Science is thus the philosophy of the unconscious. Now the unconscious cause of this great mediæval folly that spread through Europe is to be found in the economic conditions of feudalism. It was the conquering impulse, condemned to desuetude in Europe, which sought its outlet in a series of transmarine expeditions and ended by founding a

${ }^{1}$ In England, for example, the Norman lords used up their energies in intestine broils up to 1152 , but at this point, no longer able to consume their activities and forces in internal dissentions, they abandoned their former centres of activity, England and Normandy, to conquer and colonise abroad (Thicrry, Histoire de la conquête d'Angleterre, Brussels, 1839 , p. 8). 
religious colony in distant Syria; precisely as in our day the instinct of accumulation, thrown out of normal employment in Europe, rushes into over-sea enterprise and hazardous speculation. The spirit of exaltation inspired in the European mind by Peter the Hermit finds a perfect analogy in the enthusiasm momentarily aroused in Holland for speculation in tuiips, or in England for draining the Red Sea, or for a host of other insane projects. And to-day we have cxamples of the same thing in the financial schemes that excite the wildest impulses in the wisest of modem nations. The same cause lies at the root of all these phenomena, and when we compare them one with another their marvellous and inexplicable character disappears. Thus once more we find ourselves compelled to recognise with Herder that every historical fact is a natural phenomenon.

The economic character of the crusades comes out very clearly; morcover, if we talse the trouble to examine the various phases of these strange enterprises, which, according to the opinion of one intelligent historian, were inspired solcly by cupidity and the desire of booty. We know that at the time of the fourth crusade the Venetians only consented to carry the warriors of the Faith on their vessels on condition that they should be richly remunerated and share in half the booty secured. And as some of the crusaders were unable to pay the sums they owed the Republic of Venice, the Doge, Henry Dandolo, proposed that they should acquit themselves of their obligation by undertaking a crusade against the cnemies of St. Marc, and particularly against Zara. No more brutal evidence of the economic basis of the morement and its purely commercial and capitalistic ends could be furnished than this crusade against a Cliristion town; for clearly the religious motive had no place in any such enterprise. The preachers of the sixth crusate themselves entered into the vicious circle of speculation, and paid far more attention to gathering in the funds than to assembling the men-at-arms, even going so far as to grant the same absolution to those who dishursed a fixed sum as to those who personally cmolled. And it is a significant fact that the concuest of the Holy Sepulche-which was 
to have crowned an enterprise that apparently had no further end in view-was made but an episode in the affair, and finally became an incident in the attempted colonisation of Asia on the feudal principle of Europe. Every one is aware that the feudal and commercial struggles, which found but a limited field of action in Europe, were given free reign among the new states thus created; that Christians fought on these fields no longer against infidels but against Christians; and that it was these later conflicts that accomplished the ruin of the principalities, and made the entire conquest ephemeral. ${ }^{1}$ These facts taken together ought to be enough to persuade even the most determined illusionist that history really turns upon economic facts, whose influence the brilliant effulgence of faith succeeds but imperfectly in concealing.

All the phenomena thus far mentioned are peculiar to the feudal system. Militant politics continue to prevail, however, through the wage economy so long as political supremacy belongs to land-rent; for rent, like feudal revenues, exempts its owners from the cares of accumulation, and induces them to devote their energies to military enterprises. Thus in our day the countries in which land-rent predominates politicallyAustria, Germany and Russia - are the only ones where military politics are particularly accentuated. And in all countries we note a recrudescence of militarism at times when landrents are for any reason increased. But the moment political power is conquered by profits, and when accumulation becomes accordingly the normal function of property, the proprietors find active employment for their energies in capitalisation and the direction of industrial enterprise. Thus they have neither

${ }^{1}$ Kruger, Geschichte der Kreuzzïge, Berlin, 1880, pp. 30, 64, 267, 349, etc. In 1234 " the Emperor Frederick departed from Apulia and sailcd across the sea, more to obtain the lordship of Jerusalem than for any particular advantage to Christiapity. His purpose was, indeed, very clcar, for, upon landing in Cyprus, he did not undertake to wage war upon the Saracens, but only against Christians" (Villani, loc. cit., ii., p. 23). The Italian poct Grossi in his poem, I lonbardi alla prima Crociatu (canto $\mathrm{xv}$.), paints a vivid picture of the avarice that actuated the crusaders. 
the means nor the desires to fritter away their forces in use less wars. Henceforth militant politics are practically put aside. This is why in all countries the transition from the rule of rent to the rule of profits has brought with it a parallel transition from militant to industrial politics. We have proof of this in the change that occurred in English politics when Disraeli gave way to Gladstone as Prime Nlinister. Thus as the revenue basis alters, either by reason of the change from slavery or serfdom to the wage system, or following the transition within the wage system itself from the political supremacy of rent to the political predominance of profits, a correlative alteration is produced in the constitution of society, which passes from the milimant to the industrial type. It is evident, therefore, that this distinction, which is wrongly credited to Herbert Spencer (Saint-Simon and before him J. B. Say ${ }^{1}$ mentioned it at the beginning of this century), is really rooted in the economic conditions that determine the character of the revenues.

As a result, war is only resorted to under the wage system as a subsidiary method of furthering the expansion of accunulation and rounding out capitalistic revenues after other more pacific and economic means have been tried without success. One consequence of this change is, therefore, the declining frequency of warfare in modern times. This is contrary, however, to the opinion of those who hold that wars are the result of an excess of population; for according to our supposition they diminish in frequency in proportion as population increases. Other economic motives also cnter in, beside the influence of industrial revenues, to diminish the frequency of modern warfare, and among others we may mention the increasing predominance of capital invested in industrial enterprise ${ }^{2}$ and the enormous

1 J. B. Say, Traité d'économie folitique, 7th ed., Paris, 1scio, pp. 375.77. Hubbard, Saint-Simon, sa vie at ses travalux, I'aris, 1857, p. 199. Bazard et Enfantin, Exposition de la doctrine de Saint-Simon, Brussels, 1831, p. 96 .

${ }^{2}$ Fawcett was thus right in ranging himself in opposition to every proposal to guarantec property in war lines by an internalional convention, for it is just this danger of the destruction of property that makes wars now-a-days of such rale ciccurrence. 
cost of modern warfare which makes it impossible for the less opulent nations to engage in such struggles. For example, it was simply on economic grounds that the aristocratic king of France felt constrained to recognise William of Orange sovcreign of England, for while French resources were exhausted English finances were in a flourishing condition, thus rendering the eventuality of war between the two nations a thing to be dreaded by France. In this way the very economic conditions which formerly fomented war now-a-days make for peace. ${ }^{1}$ Another consequence flowing from the transition to the wage economy is the essentially commercial character of modern warfare that loolss only to the advantage of the bourgeois class which furnishes the means and manufactures the necessary instruments. ${ }^{2}$ Statistics have actually proved that of 286 wars 258 were distinctly due to economic causes," and that behind the remaining 28 cases, which were apparently fought on religious grounds, economic influences were likewise at work though their effects were concealed. ${ }^{4}$ One is really cmbarrassed in the choice of the many examples that go to prove this incontestable fact, that modern wars are waged lor the enrichment of the bourgeoisie. Economic reasons led Louis XIV. to undertalie his rash and venturesome war against Holland, since Colbert, hoping to make good a financial deficit which he was unable to meet by the imposition of new taxes,

${ }^{1}$ Leroy-Beaulieu, Recherches économiques [etc.] sur les guerres contem. poraires, Paris, 1869, p. 285 ff.

2 "Jusqu'en 1498 les princes avaient fait la guerre pour conquérir des territoires ; depuis lors on la fit pour établir des agences commerciales" (Voltaire).

3"Wars are exclusively the result of a utilitarian calculation" (Ferrara, Nuova Antologia, 1866, p. 733).

${ }^{4}$ The war of the Cevennes, for example, under the guise of a religious schism, hid a revolt of the Camisards, or poor elasses, against the tyranny of property. In like manner, though at a very different epoch, the revolution fomented in Ephesus by the manufacturers of Pagan amulets, with a view to preventing the introduction of Christianity, was certainly not actuated by any rcligious motives, but rather by a fear lest the introduction of Christianity would work injury to the sale of their amulets to the nunierous visitors who frequented the temple of the goduless. 
urged France into this conflict with her commercial neighbour with a view to inheriting the latter's industrial prosperity. It was the desire for commercial expansion that led to the celebrated opium war between England and China, which was terminated by the peace of Nankin and resulted in the opening up of several Chinese ports to the Europeans.' England's anti-Jacobin war against revolutionary France was the result of the anxiety experienced by the British aristocracy at the successes of the Continental bourgeoisie. ${ }^{2}$ And why, indeed, are wars undertaken if not to conquer colonies which permit the employment of fresh capital, to acquire commercial monopolies, or to obtain the exclusive use of certain highways of commerce? The wage society cannot comprehend why a crusade should have been undertaken to redeem the Holy Sepulchre, but it would readily understand a movement in this direction if it were a question of preserving the neutrality of the isthmus of Sue\%.

Economic conditions not only exert their influence thus in making wars more or less frequent and in modifying the ends in view, but they also determine the military systems of different epochs, the make-up of the armies, and even the means of destruction. Thus no very profound knowledge of military history is required to see that the economic conditions surrounding feudalism necessarily resulted in the prevalence of cavalry over infantry; for the cavalry was composed exclusively

${ }^{1}$ If one desires to be persuaded of the base cupidity which determined this strange war one has only to read Justin MeCarthy's interesting and instructive work, A History of our Own Times, Tauchnitz ed., i., p. $127 \mathrm{ff}$.

${ }^{2}$ Carpi (Alcunc considerazioni economiche sulle imposte, sul debito fubblico, ccc, Turin, 1850, pp. 108-9) mentions as striking examples of sacrifices willingly made by capitalists for the State, those made by English capitalists who aided the Government in pursuing the war against Napoleon, and those made by American capitalists who supported the lRepublic in its struggle with Mcxico. But these wars were really dictated hy the self-interests of the capitalists and landed proprictors, for even as the inlluence of the British aristocracy impelled England to her war against France, so in like manner the necessity of extending Anerican capitaldrove the Union to war with its less powerful neighbour. (Bryce, loc. cit., iii., p. 264). 
of the nobles, who were useless to production and yet always ready to take to arms; while the infantry, on the other hand, could only be recruited from small proprietors and copy-holders. But military service is the surest means of ruining small proprietors, as it always results in their expropriation. Continued service thus led to the gradual destruction of the infantry by drying up the source of its recruitment. Hence the impossibility of maintaining a national infantry during the feudal period. The States that needed foot-soldiers found themselves, consequently, obliged to hire foreign mercenaries. The nameless proletarian multitude, created by the wage economy, possessing neither hearth nor home, constitutes, however, a natural infantry contingent, and makes it possible to accord the present high importance to this branch of the service. It is also the existence of this proletarian class that leads to the institution of permanent armies, whose ranks are filled with a disinherited multitude which is only too glad to obtain a bare means of livelihood in return for its military services. It is evident, indeed, that the maintenance of a permanent army would be a financial impossibility if the soldiers demanded for their military services anything beyond such simple subsistence. The writers of a former epoch, more clearsighted than those of our day, did not fail to take account of the interesting effect of the impoverishment of the people in facilitating the establishment of the modern military system. Thus at the beginning of the last century Daniel Defoe wrote that it was poverty which made men soldiers and drove them into the army, and that the very difficulty of enrolling Englishmen in the army went to prove that they lived in comparative comfort. ${ }^{1}$ Some ten years later an intelligent clergyman remarked: "The fleets and the armies of a State would soon lack marines and soldiers if diligence and sobriety everywhere prevailed, for what except miscry could drive the lower classes of society to incur all the horrors of war?"2 Macaulay, in his turn, saw proof of the sad condition of the English working man in the fact that the State succeeded with so 
little difficulty in recruiting foot-soldiers, although the pay only amounted to $4 \mathrm{~s}$. 8d. a week. ${ }^{1}$ And a hundred or more other writers have authenticated this influence of the nascent proletariat upon the formation of permanent armies.

Not only is a new military organisation thus effected through the economic conditions surrounding the wage system, but the art of strategy is also considerably modified thereby. As a competent authority writes: "The second stage of development in the military art was not introduced by the invention of gunpowder-this only hastened its natural evolution-but by the democratic transformation of society and the employment of infantry in mass ".2 The change from the disposition of infantry in squares to its formation in columns was the inevitable result of the necessity of mobilizing the inmense masses of men which the new cconomic regime adcled to the army. In fact so numerous and important have the influences exerted by economic conditions upon the organisation of armies become that they have now-a-days to be taken account of by military tacticians, and not very long since Captain Max Jahns, a Prussian staff-officer, explicitly recognised that "the foundation of the military system is, in the first instance, the economic condition of the people".".

Though normally the consequence of economic causes, war, in its turn, cxercises a powerful counter-influence upon economic conditions. and hecomes an important factor in their development. Warfare, in short, renders the contrasts of an antiquated economic systen more acute, and hastens its inevitable decay. Thus the 'Thirty Years' War contributed very powerfully to the cconomic development of Germany by hastening the dissolution of the feudal system and instituting bourgeois property. In more recent times, the victories of Napoleon compelled Prussia to abolish the last vestiges of feudalism by freeing the peasants, and half a century later the Crimean War did the same for Russia. The process is not difficult to dis-

'Macaulay, History of England, ch. xix.

2Marselli, La guerra c la sua storiu, Milano, 1881, iii., ؟. 414.

${ }^{3}$ Engels, Duhrings Umaülzung der ll'issenschuft. 1.cipzig, 1877, p. 145. Sec also Guerrini, La gucrra e lo stato sociale, Rome, 1892, p. 95 ff. 
cover. Wars of themselves cause a vast destruction of capital, instruments of production and productive forces. Production is accordingly retarded, and this emphasises the contradictions of the declining social form. Besides, if the war is unsuccessful its very results offer clear proof of a vitiated economic system, and usually precipitate its downfall. ${ }^{1}$ Economic conditions thus give rise to war, and war, in its turn, substantially modifies the economic system.

The influences that economic conditions exert upon politics are exhibited in a still more pronounced manner in the conquest of one people by another. Economists have long regarded the expansion of conquering races as the result of an exuberance of population; but in reality the causes are deeper and much morc complex. In the first place, the excess of population leading to conquest does not have to be an excess relative to the production of food-stuffs as the Malthusian school takes it; for such an excess is inconceivable during the many hundred years when free land existed in abundance, and conquest was nevertheless a fundamental institution of humanity. If conquest be due to an augmentation of population, we must understand this to mean an increase in the number of the unproductive labourers; for if on account of their numbers these men are no longer able to acquire a sufficient share of national wealth, they will naturally be inclined to provoke a war in order to better their fortunes at the expense of foreign revenues. ${ }^{2}$ And even though such an increase of the population does not directly occasion conquest, economic motives usually conspire to do so. In China, for example, commerce was the regular

1 Tchernitchewski (Lettres sans adresse, Geneva, 1891, pp. 15, 25, etc.) affirms that the Crimean War contributed powerfully to the abolition of serfdom in Russia, because, in the eyes of public opinion, the cause of defeat was the feudal system that prevailed in this great nation. It seems to me, howcver, that, side by side with this purely psychological reason, there runs an economic influence as well, inasmuch as the destruction of capital during the war rendered the limits opposed to production by the serf system more apparent, and thus urged the necessity of abolishing it.

${ }^{2}$ Turner (History of the Anglo-Saxons, London, 1820, i., p. 478) develops this point admirably. 
precursor of conquest, and invasions were instigated by the necessity of opening up marliets for Chinese products in Central and Western Asia. The conquests of the Phonicians were in like manner inspired by the exigencies of trade, and regularly followed their commercial peregrinations. ${ }^{1}$

Conquest is also very likely to result if a different proportion exist between the different kinds of revenue in contiguous States. If one kind of revenue dominate economically and politically in one country and another in another, the political aggregation of the two countries might very well lead to the ascendency of one of the locally subordinate revenues over the whole. Important political consequences are apt to flow from this condition of affairs; for the hope of gaining absolute dominion over so large an area naturally urges the locally subordinated revenue-holders to work for aggregation that promises supremacy. They will, therefore, be inclined to employ drastic means to accomplish their ends, even though their actions offend the loftier principles of patriotism. In 1848, for example, while land-rent predominated in Austria, and profits prevailed in Prussia, Austrian capitalists, finding themselves oppressed in their own country by rival revenue-holders, did not hesitate to solicit the ling of Prussia to dethrone the German princes and conquer Austria, as they hoped by this stroke to gain the ascendency over rent, and therewith sccure political power in the new State."

But the conditions prevailing in the conquering nation alone do not of themsclves suffice to explain the essentially bilateral fact of concuest; for in the realisation of this phenomenon the military tendencies of one nation must meet with the political inferiority of another, which thus acts as a contributory cause. And just as the bellicose activity of conquering nations is, as we have just seen, largely the result of economic causes, so in like manner is the political inferiority of the nations destined to servitude the outcome of their lower econonic condition. The conquest is thus due to the fact that the revenues of the politically inferior country are in their infancy, or have reached a

${ }^{1}$ Gumplowicz, Der Rassenkamff, 1853, pp. 319-20, 330.

Marlo, loc. cit, i., p. 407. 
stage of decline, while the revenues of the conquering State (and especially if it be a neighbouring State) are in their ascendency. When the economic inferiority of a nation is due to the immaturity of its capitalistic development, it is likely to pass uncler the commercial subjection of some more powerful State. But when the inferiority is occasioned by the decrepitude of its capitalistic system, the weaker State usually becomes a prey to the stronger. In the former case we have the colony, the protectorate, or some other form of subjection; and only in the latter case do we find real conquest.

Numerous examples go to show that this immaturity of the capitalistic system renders a nation an easy prey to political organisms that have reached a maturer stage. Thus the nascent revenues of young America developed a puny economic system at first, and the country was consequently given over to the domination of the English, who exploited it without scruple until American revenues reached their maturity and broke away from the tutelage and exactions of the mother country. The insufficient development of the capitalistic revenues of Portugal in the eighteenth century led in like manner to a form of economic dependence upon England that was almost colonial in its character, and this lasted until the progressive augmentation of Portuguese national wealth made it possible for Pombal to free his country from the British yoke. ${ }^{1}$ Almost at the same time a falling off in their incomes induced the Swedish nobles to sell themselves, some to France and others to Russia. Hence their historical division into two hostile parties, the Hats and the Caps, the former adopting a pro-French policy whenever they were victorious, and the latter following a Russian lead whenever they triumphed; hence, also, the succession of wars that Sweden was obliged to undertake, sometimes in the interest of one of their foreign masters and sometimes in the interest of the other. ${ }^{2}$

${ }^{\prime}$ Oncken, Zeitalter Friedrieh's des Grossen, Berlin, 1882, ii., p. 352.

${ }^{2}$ Lemoine, Abrégé de l'histoire du Suède, Paris, 1844, ii., p. $240 \mathrm{ff}$. Later on when France and Russia were united under the genius of Napoleon, they compelled Sweden to adhere to the continental blockade, and when the King of Swcden refused to comply he was deposed and replaced by Charles XIIJ. (loc. cit., p. 345). 
But a much more important relation-one in which we see still more clearly that political subjection springs from economic inferiority - is the protectorate of creditor over debtor countries. When a country which has contracted a debt is unable, on account of the slenderness of its income, to offer sufficient guarantec for the punctual payment of interest, what happens? Sometimes an out and out conquest of the debtor country follows. Thus France's attempted conquest of Mexico during the second empire was undertaken solely with the view of guaranteeing the interest of French citizens holding Mlexican securities. But more frequently the insufficient guarantee of an international loan gives rise to the appointment of a financial commission by the creditor countries in order to protect their rights and guard the fate of their invested capital. The appointment of such a commission usually amounts, in the end, however, to a veritable concuest. IVe have examples of this in Egypt, which has to all practical purposes become a British province, and in Tunis, which has in like manner become a dependency of France, who supplied the greater part of the loan. ${ }^{1}$ The Egyptian revolt against the foreign domination resulting from the deht came to nothing, as it met with invincible opposition from capitalistic combinations, and Telel-Kebir's success, bought with money, was the most brilliant victory wealth has ever obtaincd on the field of battle.

No less numerous are the examples going to show that the decrepitude of a nation's capitalistic sy'stem lays it open to invasion by all other peoples whose affairs are in a more flourishing condition. Thus it was the declining state of Imperial finances that occasioned Rome's economic and political weakness, and placed all Italy at the mercy of the invading tribes whose increasing revenues gave them an immense superiority over the Latin races. The cruel fate reserved for all nations on a declining stage of economic evolution, and surrounded by other nations in the ascendent phase of their development, is written in inclelible lines in the history of Britain Ireland and Poland. Britain became an 
casy prey to the Anglo-Saxons on account of the state of anarchy resulting from economic disassociation which divided the nation up among a number of petty tyrants and tribal chiefs. $^{1}$ This result was effected in a still more striking manner in lreland. The clan system, leaving the nation disassociated and anarchic, continued to persist in Ireland long after it had been replaced in England by an economic system which made for association among producers. The multitude of restraints that limited the productivity of labour, and the existence of an economic system which rendered association impossible, led Irish producers to become involved in a series of intestine broils which caused their all too insufficient revenues to decline. The economic anarchy resulting from these continual conflicts between the chiefs of rival clans, and the consequent disorganisation of the primitive communistic economy, constituted the real cause of the political anarchy which reduced green Erin to a state of impotency and placed her in the terrible clutches of her English neighbour. ${ }^{2}$ The same thing was true of Poland. There the continued decline in production, due to the progressive exacerbation of feudal relations, urged landed proprietors to resort to exactions and usurpation, hoping by these means to acquire an income which economic enterprise no longer assured. In order to wrest booty from one another, the Polish lords then gave themselves over to fratricidal struggles, and began to practise pitiless extortion upon their serfs. When the gains from such intestine conflicts began to fall off, the Polish lords were seized with a wild desire for conquest, and overran the neighbouring territory, bent upon procuring at any price that increase of income which neither production nor internal warfare had proved competent to provide. At the time when the feudal revenues of Poland were thus becoming reduced to so miserable a state, the nations of central and eastern Europe were developing the wage system and had already succeeded in substituting an improved economic organisation

"Turner, loc. cit., i., pp. 233, 249. "Tota insula, diversis regibus divisa, subjacuit," said one of the chroniclers of this period, ibid., p. 304.

"Meyer and Ardant, La quostion agraire, 1883, p. $133 \mathrm{ff}$. 
for the older condition of anarchy. This diversity in the economic systems of the countries in question resulted in considerable political variation as well. In Sweden and Denmark the ruin of the feudal system effected a breach in the power of the nobility and substituted a strong hereditary monarchy for the older elective monarchy, under cover of which the nobles had really exercised full sway. In Poland, however, the continuance of feudal revenues established the elective principle, and this meant an impotent monarchy, the arbitrary government of a few lords. and unrestrained political anarchy. 1 It was but natural, therefore, that a constitution of this kind, resulting from the declining state of the revenues, should have rendered Poland powerless before her neighbours, who had already attained a higher political and cconomic position. Moreover, the very extortion to which the Polish peasants were subjected broke down all sentiment of solidarity between them and their lords, and made them the natural allies of the foreign invaders whose serfs cnjoyed a more fortunate lot. There is therefore no reason to be surprised that Poland fell so easy a prey before her more powerful ncighbours.

These facts would seem sufficient to expose the error under which those are labouring who set the phenomenon of concuest in opposition to the economic theory of politics. These writers emphasise the superficial fact that men who are not proprictors (the invaders) possess themselves of the lands and chattels of the vanquished, and, without going further, conclude from this that it is political force which gives rise to property relations But in making this assertion they fail to note that before the concuest occurred the invaders were unproductive labourers who participated in the revenues of their own country, and that their victory was only possible because of the stuperiority of these revenues over those of the vancuished nation. The conquest cannot, therefore, be regarded as a triumph of foree over revenue, but must rather be looked upon as the victory of one kind of revenue over another inferior form."

'Oncken, loc. cit., p. $436 \mathrm{ff}$. Meyer and Ardant, loc. cit., ch. vi.

"Even in Tacitus the distinction between the people qui regnontur and those qui non rignantur is traced back to the system of landed property, 
We do not wish to deny that political conquest may sometimes effect a change in the economic structure of society, but we do affirm that the result is not directly due to conquest itself, but is rather derived from the fact that conquest is apt to modify the organic conditions of the economic system. It is of course true that conquest may determine a change in the personality of the property-holders, either from the fact that the invaders appropriate the lands of the vanquished (as did the barbarians in Italy, the Normans in England, and the English in Ireland), or from the fact that the conquering nation may impose a tribute upon the vanquished people. This point is so clear that it is not necessary to insist upon it any further. Suffice it to remark that economic subjection weighs far more heavily upon a vanquished people than simple political conquest. This is why lreland, quivering with rage ever since she was brought into economic subjection by England, still fosters a bitter resentment which no concessions of political autonomy can lessen in the least; and why Alsace and Lorraine, on the other hand, which were only conquered politically by France, so soon became loyal.

It is only when conquest operates against the very foundations of the economic system, and alters the appropriation of the soil, that it effects a real transformation of economic conditions and engenders a social revolution. It is necessary, however, at this point to establish a distinction : conquest may result either in the superposition of one people over another,

i.e., to economic conditions. After all we have said it is easy to see how far removed we stand from the theory of Gumplowicz, who looks upon history and the make-up of nations as the product of international conflicts, without remarking that nations must exist before they can contend with one another, and must consequently possess an economic and political organisation, which, existing before the conflict, cannot possibly be the product thereof. As a matter of fact, the process is reversed, inasmuch as it is the internal conditions of each of the social groups which regulate and deternine the relations between the different groups themselves. This apparently simple observation has escaped the attention of both Spencer and Molinari, who also explain the social constitution of the different nations as the result of the international relations of war and conquest. 
or in the substitution of one pcople for another. In the former case, conquest results in an augmentation of population, and this, in turn, necessitatcs an improvement in the methods of moduction. The retention of the older economic system-cither of the conquering or of the vanquished people-is thus rendered impossible. Under such conditions, conquest not only results in a change in the personality of the proprietors, but also effects an economic revolution by reason of the resulting increase of population on a limited territory. But in case a victorious race simply takes the place of a vanquished people - who are either cxterminated or driven out-the conquest results in no augmentation of population, and it is, therefore, unnecessary to introduce a ncw economic system, as that of the vanquished people may perfectly well be retained. Finally, when conquest occasions a diminution in the population of the conquered country, it makes for retrogression in existing economic conditions. It is evident, therefore, that the political fact of conquest which is itself the product of economic causes has no direct effect upon modifying the economic system. It only succeeds in effecting this result indirectly, in so far as it alters the relation between population and production upon which the existing economic system is based. In short, just as war gives occasion to new economic forms by destroying the means of production and accentuating the unproductiveness of the declining economic system, so conquest also brings about a like result by causing an increase of population. War, in other words, lessens the resistance offered by the economic system to be destroyed; conquest adds the necessary impulse to effect the change. Both operate upon the cause of economic evolution, namely, the contrast between the increase of population and the limits imposed upon production by the existing economic system; but war affects the latter term of the contrast, and conquest the former.

And as every economic change involves a corresponding political change, whenever conquest modifics economic conditions, it occasions ipso facto a radical modification in politics and law. But all the alterations that national law undergoes when brought under foreign domination are not to be explained 
by the simple fact of conquest. They are rather the result of the transformation which conquest effects in the economic conditions of the vanquished country by superimposing a new population upon the old This is so true, that when conquest occasions no profound modification in economic conditions it determines likewise no great legal or political change. Thus the phenomena succeed one another as follows: economic conditions lead to conquest, conquest, in the majority of cases, modifies existing economic relations, and the nodification of these relations, in its turn, engenders a corresponding transformation in the political institutions of the conquered country.

History offers the clearest proof of the truth of these assertions. The barbarians who effected their inroads into Italy at the time when Rome was sinking into decline, superimposed themselves upon the vanquished provincials. The resulting increase of population rendered Roman and German slavery unprofitable and necessitated the substitution of a more productive system. The economic institutions of the new State and the political institutions resulting therefrom both presented, therefore, a marked contrast with the older Roman and German constitutions. The same was true of the Norman conquest of England, which brought forth institutions differing from those of the earlier Normans; and of the Norman conquest of Sicily, which occasioned a complete transition from slavery to serfdom. On the other hand, the English conquest of India adding but slightly to the population of the country, left economic conditions unaltered and exerted but little influence upon the political and judicial systems. It is not surprising therefore that the contact of British civilisation has not yet resulted in detaching the rreat Asiatic peninsula from the sway of its legendary law. If finally we wish to note the effects of a diminution in the population of the vanquished country we have only to follow the course of events in Spain down to the seventeenth century. in the sterile northern provinces the Christians lived in wretched penury, burdened with a constant excess of population; while in the fertile provinces of the south, the Moors had their granaries filled to overflowing with food-stuffs and en,oyed a brilliant era of 
prosperity. Hunger, as Liebig remarked, ${ }^{1}$ urged the Christians to attack the Moors and inspired them with an heroic bravery that confounded the infidels and drove them from the peninsula. Then the Christians established themselves in the provinces abandoned by the Moors. But as the new population was less dense than the old it was no longer necessary to resort to the energetic productive methods which, under the Moorish régime, attained such wonlerful perfection. The marvellous irrigation works that the Moors had built were accordingly either abandoned or destroyed, production retrograded, and wasteful cultivation finally ended in exhausting the formerly fertile soils of Spain. Now what caused all this if not the diminution of population which effected a corresponding retrogression in productive methods and consequently in the economic and political constitution of the new State? In Ireland, likewise, the English conquest led to depopulation and determined a decline in production, bringing with it the destruction of a grcat number of industries, the ruin of agriculture, and the decay of political life. Thus not only is conquest itself the product of economic causes but the phenomena consequential upon conquest and the political régime derived therefrom are also determined according to the different economic conditions that conquest entails.

Nor does capitalistic revenue reach the limits of its influence in thus contracting and breaking alliances. in making wars, in effecting conquests, and in working all the political wonders the common mind usually attributes to the will of an absolute monarch.

Those who are imbued with the idea upon which the present studies rest, namely, that economic revenue is the basis of political power, will find themselves forced to conclude that political revolutions are likewise econonic at heart, and that consequently the majority of then are inspired by the revenueholders themselves. Thus those who are excluded from property either keep out of the struggle entirely or fight for

'1.iebig, Die Chomic in ihrer Anwendung ant Agrikultur und Physiologic, Braunschweig, 1862, i..,p. 196. Sec also Engels, Diehring's Umwälzung der Wissenschaft, p. 256. 
the proprietors through ignorance of the ends in view. This truth (of which we shall speak more at length in the following chapter) finds its most striking demonstration in the great political fact of our age, namely, the process of political aggregation, or, in other words, the formation of national States. When we reflect upon the grand revolution from which Italy emerged a united State, we ask ourselves with astonishment why it was that this country attained its independence and national unity so much later than all the others. Far from the Italian revolution being without analogy with those that gave birth to the other nations of Europe, it was, really, but the last episode in a succession of glorious struggles for national unity. The political conditions that agitated Italy for forty years were but the last phase of a state of affairs common to all the States of Europe, as long as the feudal system dismembered the nations in a number of warring principalities. In the other European States political disaggregation gave place to centralised government, which was formed and consolidated between the thirteenth and fifteenth centuries. But in ltaly disaggregation continued down to the present day. And why this difference? In France, England, and a number of other countries, the feudal system was replaced by a centralised government through the peculiar activity of the capitalists who found themselves compelled to reinforce the political authority of the monarch in order to contend successfully with the landed proprietors. Hence we read of French and English towns supporting royal authority by every means in their power, and aiding the monarch to free himself from the control of the feudal lords. And besides this necessity of centralising the sovereign power in order to carry on its struggle with landed property, capital likewise needed centralisation in order to employ its best energies in breaking down the provincial, feudal and communal barriers opposed to its expansion. These obstacles were the inevitable outcome of political disaggregation, and as accumulation progressed they ultimately became intolerable. Consequently, the very development of capitalistic wealth worked toward the national unification of these countries. 
In Italy, however, certain historical circumstances prevented the perfect reproduction of these phenomena. For a number of reasons, the most important being the lack of centralisation and the more rapid development of personal capital,' feudal property never attained the dominant power in Italy it elsewhere secured; while, on the other hand, the increasing power of the towns overthrew feudalism on the field of battle and thereby assured the bourgeoisie their political superiority. The Italian bourgeoisie was thus in a position to hold its own against feudal property without resorting to the institution of a centralised authority. In France and England the towns looked to royal authority for support and, in their turn, lent the monarch their assistance; but in Italy, the aid of the central government was never required by the bourgeoisie. It was, on the contrary, the feudal classes which there rallied around the Emperor, while the bourgeoisie preferred to range themselves under the spiritual and transitory authority of the Pope whenever they found it necessary to have recourse to some central power in their struggle with the fiefs. As a result, the bourgeois class, which, in other countries, exercised so powerful a unifying influence, contributed in Italy to perpetuate the existing political disaggregation. Morcover capital, though it appeared earlier in Italy than elsewhere, failed for a long time to attain the same vigorous development as in other countries. Like a precocious plant it remained stunted in its growth for a considerable period. On reaching its mature stage, and finding the obstacles presented hy political disaggregation no longer consistent with its growth, capital in England and France broke down these barriers in order to unify the State. But at this time Italian capital was weak and but slightly developed, and it chose accordingly to put up with the obstacles that confronted it and adapt itself to the resulting state of political disaggregation. Nevertheless, Italian capital finally attained a degree of development that rendered the difficulties arising from political disaggregation no longer supportable, and national unity then became an essential 
condition to the very life of property. Then at last capital made its final effort to overcome the obstacles that stood in the way of its development and do away with the political disassociation that lay at the root of the difficulty. ${ }^{1}$ There can be no doubt, therefore, that this capitalistic movement added enormously to the success of the revolution which ended so gloriously in the unification of Italy. ${ }^{2}$

${ }^{1}$ Italian national unity was necessitated by organic economic conditions, and the inherent necessity of the case was well recognised by the great statesman instrumental in bringing it about. With marvellous intuition he perceived the dependence of the political factors upon the economic situation, and expressed himself in this rcgard as follows: "We proclaim with assurance that Italy's political resurrection, now being celebrated with brotherly enthusiasm in Romagna, Tuscany and Piedmont, constitutes an indubitable sign of a new era in the industry and commerce of our country". For this rcason "let us accord as hearty co-operation as we can in doing away with all kinds of internal customs and cementing the economic unity of the peninsula " (Cavour, "Influenza delle Riforme sulle condizioni economiche dell' Italia," in the Risorgincnto of 15th Deccmber, 1848). See also a remarkable passage in the Saggi di economia, of Ferrara, 1890, p. 168.

2 "C'ètait sur le terrain des affaires que les Italiens de 1845 voulaient porter la lutte. La révolution italienne devait désormais se faire la main dans la poche. Suivant Petitti, les chemins de fer devaient amener la suppression de toutes les frontières; suivant Cavour le groupement de tous les intcrets, l'association des capitaux aurait bientôt dicté la loi à toutcs les monarchies" (Costa de Beauregard. Les dernicires annécs du roi Churles Albcrt, Paris, 1870 , pp. 13, 39, etc.). It was not by chance that Cobden was made so much of in Italy, but with political intent; because every one recognised that cconomic reforms were the basis of political reforms (ibid.). The origin of the war betwcen Piedmont and Austria was economic in character. as it was the customs duties that Austria levied upon Piedmontese wines that led to the war of 1848.

In several Italian States the insurrection was also the result of a reaction on the part of the bourgeoisie against a form of government that oppresscd them; such, for example, was the case in the Kingdom of Niples and in Lombardy. Of themselves such reactions would, however, only have led to the institution of a more liberal form of government, and not to the union of the different parts of Italy into a single State, This unification could only have resulted from the peculiar advantages it assured to Italian capital.

But however definite the advantage that Italian unity accorded to capital, immcdiate injury, neverthcless, rcsulted therefrom in the form of 
The long delay in realising German national unity was likewise due to economic causes. Feudal property, which was allpowerful in Germany, succeeded in reducing the normal conflict between feudalism and the towns to very small proportions, and made it impossible for political unity to result therefrom. Capital, moreover, appeared later in Germany than in the other countries of Europe, and, being overbalanced by the preponderance of landed property, it failed for a long time to acquire sufficient energy to overcome the obstacles of political disaggregation. The conditions of Germany and Italy thus present a strange contrast. In Italy the weakness of the feudal class and the precocity of capital produced the same results as were in Germany derived from the predominance of the feudal lords and the tardy growth of capital. Nevcrtheless, the progressive development of capital in Germany, though retarded by multifarious factors, still lept steadily on, and finally rendered the old economic and political divisions intolerable. Then followed the heroic period of German national unification. The essentially economic character of this great national movement is shown very clearly from the fact that it was inaugurated by the successful institution of the German customs-union or Zollverein, effected between 1828 and 1851. This league was formed with the definite purpose of breaking down the then existing barriers which limited the free development of capital between the several German States. The Zollverein was thus the first and imperfect expedient resorted to by capital, whose national demands could only find ultimate satisfaction in the political unification of Germany. ${ }^{1}$

Turning our attention, finally, to another country very different in character and far distant from those we have thus far spoken of, namely, North America, we find that there again political union followed as the result of commercial and capita-

personal sacrifice and territorial devastation. It is, therefore, no matter of surprise that the Bourse, which only considers the present moment without looking forward into the future, should have responded unfavourably to the moxement We know, in fact, that the Italian Bourse declined with cvery success of the national cause (Piccinelli, Vatori publici, Milan, 1890, pp. 205-7).

'Roseher, System, iv., p. $416 \mathrm{ff}$. 
listic exigencies. The earliest form of American union was anarchic to the point of producing almost complete political disaggregation and seriously prejudicial to commerce. It was the desire shared by all to check this process of disaggregation that led the States in 1786 to send delegates to the convention at Annapolis. This convention had no other end in view than to regulate commerce, but it really laid the foundations of American political union; for this was found to be the only means of putting an end to the existing commercial anarchy. Proof of this is found in the fact that the first advantage the Americans took of their political unification was to confide to Congress the power, heretofore exercised by the several States, of regulating interstate and foreign commerce. As an American writer has expressed it: "It is not a little remarkable that the suggestion which finally led to the relief, without which as a nation we must soon have perished, strongly supports the philosophical maxim of modern times, that of all the agencies of civilisation and progress commerce is the most efficient. What our deranged finances, our discreditable failure to pay our debts, and the sufferings of our soldiers could not force the several States to attempt, was brought about by. a desire to be released from the evils of an unregulated and burdensome commercial intercourse." 1

Thus, always and everywhere, the capitalistic economy at a certain stage in its development, emphasises its demands for association, and the various fragments of the nation are forthwith welded together into a compact unity. Later on in its development capital finds even national limitations irksome, and endeavours to fuse these national unities, which it has succeeded in creating, into a colourless mass of cosmopolitanism. In the first half of this century Benjamin Constant wrote: "Expatriation, which was a form of punishment among the ancients, is a simple enough matter now-a-days, and instead of being distressing, is often enough agreeable. What we love in our country is the security of our possessions, the possibility of repose or peaceful activity, glory and a thousand other kinds

1 Judge Miller, quoted by Bryec, loc. cit., i., p. 25. See also the work of Ugo Rabbeno, Protcziomismo americano, Milan, 1893, pp. 131-32. 
of contentment. The word country recalls to our minds the collection of our belongings, rather than any topographic idea of any particular land. If our possessions be taken from us at home, we go and seek our fortunes elsewhere." I In our day it has gone still further. On all sides we note a tendency to belittle the cause of patriotism, and relegate it to the lumber room of psychological curios. Herbert Spencer has already characterised it as a prejudice, and while, on one side of the ocean, America is dreaming of Pan-American confederation, on the other side, generous and sanguine hopes are held out for the creation of the United States of Europe.

Objections will doubtless be offered to these explanations of ours, which make economic influences determine things that sentiment attributes to the purest and most lofty virtues. Nevertheless, if we examine the hidden mysteries of the social mechanism we shall, I think, be forced to admit that the sentimental element surrounding all great social revolutions is after all but an illusion. A necessary illusion, however, without which great events could never occur. Social evolution is, no doubt, governed by a law of inflexible logic, but the law can only be realised through the action of human beings, and such action does not follow directly from abstract logic or proceed fium a cold idea; it must be impelled by burning sentiment and ardent passion. The idea can only be realised hy appealing to the heart, or, in other words, by assuming a guise that renders it attractive. Even though there be, as Ihering says, a planetary system in the moral world whose rules are as absolute as cosmic laws, it is still necessary that, corresponding to the real cosmic system, there be an apparent system which consciousness can grasp and in whose name heroic and disinterested acts may be performed; for such acts would never be undertaken if we were able to penetrate into the mysteries of nature and follow the hidden tendencies of social evolution. Even the authors of a social revolution are unaware of its underlying principles. They perceive but a mirage which reflects the movement in the high ideals of liberty and justice.

'B. Constant, Cours de politique constitutionelle, Paris edition, 1861, ii., pp. $25+55$. 
They fight, they conquer and they die in the name of this ideal, and the illusion held forth that the laws of history may be worked out, only fades away after the revolution has been accomplished, and the law of development is fully realised; for then there is no longer any danger lest the egoistic character of the revolution should prevent or retard its realisation.

Thus after the Italian Revolution was thoroughly effected, the secrets that actuated it were gradually revealed, and history hegan its analysis The idea then slowly permeated into the national consciousness that the ltalian Revolution was an essentially hourgeois movement, actuated in the unconscious interests of the capitalist class. We may recall the words of Vico: "The Roman monarchy was aristocratic, and the liberty that Brutus established was by no means popular liberty-the liberty of the people over the great-but simply seigneurial liberty, i.e., the liberty of the great over the tyrants. When we reflect upon the oath taken (according to Aristotle) by the heroes to be the eternal enemies of the people, and when we ask ourselves what real service Curtius, Decius and Frabricius rendered the unhappy Roman populace, we are forced to admit that they only added to the existing misery by plunging the people into wars and sinking them in the ocean of usury." Vico spoke these words of the Roman Revolution, but, addressing ourselves to the Italian Revolution, we can equally well say of it: Mutato nomine de te fabula narratur. ${ }^{1}$

1 "We have accomplished a Revolution which has to a large extent heen carried out by the intelligent bourgeoisie, disinterested, libertyloving and willing to sacrifice everything for their freedom. The conditions were such that the people could not taike part in the Revolution, and for this reason they had to be foreibly carried along by us. As a result we had to work alone, and establish a régime of liberty for Italy by ourselves. Thus, though wishing to do right to all, we found ourselves confined, without our wishing it or even knowing it, within the limits of a small circle; and we have now almost come to believe that our !ittle sphere represents the entire world, forgetting that beyond our limited rroup there is another elass whose numbers are large, and for whom Italy has never eared. It is time now she began to give these a thought " (Villari, Speech before the Chamber of Deputies, 30th May, 1875). See also Sonnino, I contadini in Sicilia, p. 463. Turiello, Governo e governati in Italia, 1886, i., p. 138. Mounier (Notizie storiche snl brigantaggio, Florence, 
This truth, which to some may seem too hard, does not really pluck a single leaf from the sacred laurels of the Italian Revolutionists. Nor does it remove a single stone from the monument of respectful admiration that the nation owes to its martyrs and redeemers. Instead of belittling the victory won, this concept ought rather to inspire us for the changes yet to come. Indeed, the moment it became clear that these national revolutions were essentially bourgeois in character,

1872 , pp. 36-8, 104-6) tells us: "In 1860, when they were clamouring for the constitution, the partisans of the Bourbons explained to the lower classes that the constitution was but the outcome of the violences of the bourgeoisie, who hoped to gain possession of monarchical power in order to increase the burdens on the people and wreak vengeance on the poor for their long suffering": and again, "it was the bourgeoisic who assured the success of the liberating army". A French brochure, published in 1863, also speaks, with a slight touch of irony, "of this bourgeoisie, by whom and for whom the Italian Revolution was begun and fought out". It is a very remarkable fact-and Ugo Foscolo deplored it with his usual eloquence-that during the French Revolution the Italian people constantly took sides with Austria against the armies of the Republic; while the Italian bourgeoisic, on the contrary, cverywherc fraternised with the Republicans (Quinet). And even in the recent struggle for Italian independence, the people remained indifferent or actually hostile to the national armies, and at times-sad to relatesecretly desired the victory of the foreigner. The brutishness of the poorer classes certainly contributed largely to bring about this state of affairs-and this we do not deny-and still more the fact, so often remarked, that patriotism is a sentiment unknown to the masses who are cxcluded from the possession of property. "I made my first experience," Garibaldi remarked in this connection, "with the slight sympathy the country people feel for the national cause, either because they are priest-ridden or because they are usually inimical to their lords, who for the most part were compelled to emigrate with the invasion, leaving their peasants thus to enrich themselves at their expense" (Garibaldi, Mcmoric, p. 201). In the Neapolitan Revolution of 1799 almost all those politically condemned were the rich and the unproductive labourers. So likewise in the Italian Revolution the proportion was about the same. Of 1159 revolutionists, there were 50 labourers and 44 peasants; 49 were landed proprictors and 256 practised liberal professions (Lombroso, Il delitto politico, 1890, p 244). In the south some of the more miserable classes lent their support to the national Revolution, but this was only because the bourgeoisic encouraged the hope among them that the new Government would divide the demesne lands among the poor. 
bringing but trifling advantage to the people, the idea was bound to take possession of the popular mind that the changes effected under the auspices and in the interests of the bourgeoisie must be followed up by transformations of a purely popular character elevating the degraded condition of the most numcrous classes of society. This revelation does not tarnish the glory of those who fought for past ideals, but only destroys the reality of the ideals themselves. And of itself the revelation has created a new and still more glorious ideal that is even now being blazoned upon a standard round which future generations will rally. Had the ideal of the bourgeois revolution represented a reality, and had this revolution really established the reign of universal justice, social evolution would therewith have come to an end. It is, indeed, in pointing out the divergence between the ideals proposed by this revolution and the facts that it accomplished, that science justifies and proclaims the necessity of a further transformation, which will surely add new pages to the history of heroism and sacrifice, and point out the path the human race must follow toward still further progress. 


\section{CHAPTER IV.}

\section{REVOLUTIONS OF REVENUE AND SOVEREIGNTY.}

Economic revenue stands in the same relation to political power as a principal to his agent, or as a workman to his tool. It often happens that the agent is dismissed or the tool thrown aside, either because they no longer satisfactorily fulfil the functions demanded of them, or because the requirements of the principal or of the workman have changed. In the same way it may come to pass that the existing political power is overthrown and replaced by a different form of government, either because the governing authorities fail to properly respond to the demands of the proprietors, or because the constitution of the owning class has undergone a change. In other words, political revolutions may occur for reasons intrinsic in the powers that be, or for causes inherent in the capitalistic revenues that constitute the basis of power.

Political revolutions of the former order are of minor importance. They occur whenever the constituted authorities turn against the class whose interests they arc supposed to represent. We have already had occasion to recall several examples of reactions of this sort in spealing of the fate that property reserves for reformers who threaten its power; and we might mention a number of others still more remarliable. Thus, "it was an excessive increase of taxation that provolied the reaction of the barons at Runnymede; unless taxes had been exorbitant, Charles I. would never have been put to death; the extortions of the exchequer, under Charles II., added to the unpopularity of the Stuarts, and it was the exactions of James 11., and the suspicion that he was making up his income out of packages secretly sent him by Catholic France, that hastened the Revolution of $1688 " .1$

${ }^{1}$ Buxten, lnc. cit., Preface, viii. 
Before proceeding further, we should also remark, that the fact that political revolutions are exclusively the work of the proprietary classes explains why it is that there seems to be no coincidence between times of scarcity and revolutionary periods. An eminent authority ${ }^{1}$ has brought up this fact in opposition to our contention, but, as a matter of fact, it is a perfectly logical corollary of the main proposition; for in affirming that political revolutions emanate exclusively from the proprietary class we imply that they are removed from all influences of a rise in the price of food-stuffs, which only affect the poor and disinherited classes. Temporary periods of scarcity may, indeed, produce popular discontent or lead to passing sedition. ${ }^{2}$ More frequently, however, famines render the people inert and paralyse their energies, maling it all the easier for the proprietors to control them. On the other hand, as Villani has said, "tranquil ease engenders (among the people) a spirit of arrogance and a desire for the new". But we know of no case where temporary famine has produced a real political revolution, for this is a phenomenon peculiar to property. If the dearth continue, very different effects may, indeed, result; for permanent scarcity betrays the decline of the prevailing capitalistic regime, and may thus be regarded, if not as the real cause, at least as the presentiment of an approaching decomposition of the existing political system.

But leaving aside this really exceptional case of the constituted authorities turning against the revenues which they represent, we find ourselves before the much more important phenomenon of a change occurring in political power through a transformation in the revenues themselves. This transformation may be of two kinds : it may either proceed from an alteration in the relative force of the different kinds of revenue, or it may be the result of a modification in the organic structure of the property system itself. We already know

${ }^{1}$ Lombroso, loc. cit., p. 88; and Rossi, Il fattore economico nei moti rivoluzionari (Archivis di Psichiatria, ix., fasc. i.).

${ }^{2}$ There can be no doubt that such temporary periods of dearth do not cause popular movements. This is clear from what has been said above on the influence of indirect taxes in provoking seditions. 
that different divisions of the revenues into their several sub-species result in different forms of political power; that the government is monarchic, or aristocratic when a single kind of revenue prevails which is divided among a large number or concentrated in the hands of the few ; and democratic when two kinds of revenue are struggling for political power with about equal force. Now it follows naturally from this that any change in the distribution of the revenues must effect a corresponding revolution in political power, which passes, accordingly, from the monarchic to the aristocratic, to the democratic form, or vice versa, as the case may be. Partial political revolutions of this kind may occur at any time without effecting any change in the existing capitalistic system. They are simply the result of alterations in the apportionment of the revenues among their sub-species, rent, profits, interest, etc. Thus all the revolutions that occurred in the Greek cities, of which Aristotle and other writers of antiquity made so much, those incessant movements which transferred political power from the optimates to the people, and from capitalists to unproductive labourers or the reverse, were but the natural consejuence of an alteration in the relative preponderance of the different parts of the revenue, whose main structure still rested upon the permanent foundation of slavery.' Such was also the nature of the ceaseless conflict that occurred in the 1talian cities during the middle ages. And at the present time similar political contests establish a form of government one day which may be abolished or modified on the morrow.

Political transformations of this kind derived from a quantitative alteration in the different divisions of the revenue, despite their great frequency, are, nevertheless, of but limited importance; for they are all effected on the basis of a substantially invariable economic foundation, and cannot, consequently, occasion any essential change in the political constitution. The transformations resulting from organic secondo Aristobele (Vol., fer le onoranze a $F$. Scrafini, Florence, 1892). 
alterations in economic structure present very different and much more important characteristics. We are already aware that each successive form of capitalistic revenue tends inevitably to decline, and that out of the dissolution of the old a new form of revenue appears with its corresponding economic organisation. Now a change in the form of economic revenue necessarily engenders a revolution in political power. Thus economic revolution is bound to result in political revolution.

The researches we are here pursuing bring to light a very remarkable fact, namely, that all variations in the revenues, however produced, always tend to increase political power and render its exercise more authoritative. On the one hand, any augmentation in the revenues increases the power of the revenue-holding class; and, on the other hand, any diminution in the revenues increases the tendency among the proprietary classes to compensate themselves for the pecuniary loss by exploiting political power to their personal advantage. Thus in Germany, the efforts of the feudal lords to acquire jurisdiction over their subjects bccame greater in proportion as the revenues from their estates diminished. ${ }^{1}$ Such was also the case in France; the more feudal regulations hampered production, and the more the reaction of the peasants and artisans limited feudal revenues, so much the more were the feudal lords inclined to use their political power to make good the loss. Hence the enormous pensions granted the idle nobility and which occasioned the huge deficit that ultimately led to the revolution. An augmentation of revenue increases political power in a permanent way, however, while a diminution of revenue only adds to political power temporarily, and ends at last in destroying it altogether; for the decomposition of the revenue system leads inevitably to the ultimate decomposition of political sovereignty.

The phenomenon which marks the beginning of this process of decomposition is the breating up of the standing alliance between the revenue-holders and the unproductive labourers. From intermittent struggles these two groups are led on to a 
battle à outrance, whence only one emerges intact. Toward the decline of the classic economy, for example, the unproductive labourers, clients, and soldiers, seeing their perquisites rapidly falling off, declared open war upon the revenue-holders, represented by the Senate. Thus the old equilibrium between the army and the Senate, that had been preserved with such care by the earlier Ciesars, was ruthlessly destroyed under Severus, who organised the army for its revolt against property. ${ }^{1}$ The reaction ended, as we know, in the political defeat of the revenue-holders, who were reduced to a mere shadow of their former power, and compelled to abandon the dictatorship to the unproductive labourers composing the army. Thus the decline in the revenues derived from slavery had its immediate effect in the dissolution of political power. In like manner, the decline of the feudal revenues was accompanied by increasing violence in the standing conflict between the unproductive labourers (the ecclesiastics) and the landed proprictors. The latter, unable any longer to maintain an innumerable horde of tonsured clients, forcibly expropriated them and took back the donations they had originally granted. This process of expropriation was effected in all the countrics of Europe, but the methods by which it was carried out differed in the different States. England and Germany simply confiscated the possessions of the ecclesiastics, but France forced the Church to give them up. In the two former countries the struggrle ended in a reformation, in the latter it was settled by a concordat. Moreover, in France, where there was no Parliament, it was the king, representing the proprietary classes, who combated the clergy; white in England, where the Parliament was so strong, it was the lay lords and commoners who opposed the Church, and the strugggle thus became sharper as the political representation of the laymen increased at the expense of the clergy.2 But though the methods of expropriation differed, the

'Roscher, Casarismus, pp. 61, 71.

${ }^{2}$ It was the power of the bourgeoisic, according to Burke, that sacrificed the interests of the Church for those of a few money handlers. See also Michelet, loc. cit., iii., pp. 42-59. Mill, Dissertutions and Discussions, ii., p. 176. Gncist, Englische Voroultumg, pp. 178, 203. Gneist remarks that 
result was the same, namely, the disruption of the historic alliance between the feudal revenue-holders and the ecclesiastics and the sudden coalition of the latter with the serfs-a coalition that was effected contemporaneously in Denmark, Sweden, Germany, and in most of the countries of Europe. ${ }^{1}$ This latter coalition, by encouraging the revolt of the serfs and the poorer classes, prepared the way for the final dissolution of the feudal revenue system and led to the downfall of the entire political organisation founded thereon.

From the midst of such economic decomposition, and out of the political ruin resulting therefrom, there arises immediately a higher form of capitalistic revenue, which, in turn, effects a recomposition of political sovereignty. Thus when the collcctive economy was disaggregated, and the weaker and less well-to-do members of the communal organisation were forcibly reduced to slavery by a few usurpers, the latter also took pos. session of political power, and excluded the vanquished from all participation in the management of public affairs. ${ }^{2}$ This ancient political revolution thus made sovereignty a prerogative of freemen, even as the preceding economic revolution made liberty itself a privilege. Later on, when the slave economy likewise became disaggregated and an ephemeral expansion of small holdings spread itself over the ruins of the old system, these small owners were, in their turn, forcibly expropriated and reduced to serfdom by a handful of bandits. The usurpers, having thus gained possession of the revenues, hastened to lay hold of political power as well. The enserfed class was accordingly deprived of all right of interference in the government of

the secularisation of the ceclesiastical holdings resulted from the fact that the social function of the Church had come to an end. But to him this function consisted in inspiring proprietors with lectings of humanity toward their serfs, and not in inspiring the latter with sentiments of devotion and obediencc.

${ }^{1}$ Onclien, Zeitulter Fricdrichs, ii.,,p. $455 \mathrm{ff}$.

"Emile de Laveleye sces the origin of political incquality in the destruction of the primitive economic equality effected by the retirement of the proprietors, from the marked organisation, and by the breaking-up of communal property (Le gouvernement dans la démocratie, Paris, 1891, ii., p. 290 (ff.). 
the State, and sovereignty was parcelled out among the great landed proprietors in the form of personal jurisdiction. After this manner the feudal revolution was accomplished, which made political sovereignty the appanage of a small number of privileged personalities. When scridom was abolished modern property arose as the outcome of still another economic revolution. The new class of proprietor's, finding themselves excluded from political power which was still monopolised by a few seigniors, then instituted a revolt. They stripped the privileged lords of their personal sovereignty, and substituted the collective sovereignty of the entire capitalist class. In this way the bourgeois political revolution was effected, which completed the preceding economic revolution by according sovereignty to capital.

We shall dwell more particularly upon the character of this bourgeois revolution, because it carries with it such irresistible proof of the fact that a metamorphosis in economic structure effects a corresponding transformation in the political constitution.

If we go back to the beginnings of bourgeois omnipotence, which to-day fills the entire civil world with its ostentatious display, we shall find no trace of that dissociation of property from labour which constitutes so striking a characteristic of the modern capitalistic system. The mediaval towns, which were the cradle of the bourgeoisie, were inhabited by a population of master artisans, journeymen and apprentices, all fraternally united in craft-gills. The masters and their adepts constituted the well-to-do classes (fopolo grasso), and the ap. prentices the common people. Both classes participated in sovereignty, and disputed the supremacy in the government of the towns. Nor was political control always in the hands of the well-to-do. In 1412, for example, the common people triumphed in Paris under Simon Cathoche, and the Government established after this municipal election was the terror of the guild-masters and commercial classes. As an author of the time wrote: "Il fuisait, en ce limps, tris-pirilleur en icelle ville pour nobles hommes de quelque furti qu'ils fussent, parce que le peufle ct commun, dessus dits, avaicut grande partic de 
la domination dedans icelle". Almost at the same time "Liège presented perhaps the most perfect picture of equality the world has ever seen. Small industries participated in the government like the large, workmen had the same right of voting as their masters, even the apprentices partook of the suffrage, and the haute bourgeoisie, after a half century of domination, was so weakened that it was obliged to give up its power." I In 1378 a revolt was instituted in Florence against the well-to-do classes by the common people; "the lowly labourers" (who were oppressed by their masters and badly paid for their work) and the popular party triumphed under Michel de Lando. ${ }^{2}$ Even as late as the fifteenth century in France the entire population participated in the elections of the towns, and a feeling of close solidarity held the different factions of the bourgeoisie together. Their deputies systematically upheld the rights of labour, and denounced the abuses of the feudal lords and the misery of the rural classes. "However limited by their exclusively municipal character, the representatives of the third estate always felt themselves called upon to defend, not this or that faction, or this or that class,

1 Michelet, Histoire de France, viii., p. 13. Gerson, a writer of this time, said: "Tout le mal est venu de ce que le roi et la bonne bourgcoisie ont été en servitude par l'outrageuse entreprise des gens de petit etat". The so-called "bonne bourgcoisie" was, however, composed of working men. Then the same author adds: "L'état de la bourgeoisie, des marchands et laboureurs est figuré par les jambes qui sont de fer et partie de terre pour leur labeur et humilité à servir et à obéir. . . . en leur état droit être le fer de labeur et la terre d'humilité " (Michelet, v., p. 312). In the Pay's de Liège the eraftsmen were really sovereign, they made war and peace, they levied taxes. And, a very remarkable coincidence, the political organisation rested upon the organisation of industry (Laveleye, Le gouverncment, etc., ii., pp. 369-75). Bruges was governed by four Prudhommes, elected by the bourgeoisie who made up the population (Raynouard, Histoire du droit municipal, Paris, 1829, ii., pp. 185-86). It is equally remarkable that for so long a time the consuls of the ltalian cities were simply the consuls des arts. See for the democratic government of the Italian towns, Emiliani-Gindiei, loc. cit., pp. 533, 559.

${ }^{2}$ Machiavelli, Storic Fiorcutine, Milan, 1820, i., p. 219 ff. FalettiFossati (Il tumulto dei Ciompi, Turin, 1882, pp. 310-11) admirably depicts the Florentine Revolution of 1378 as a political struggle between the two factions of the bourgeoisie. 
but the cause of all the roturiers and all the people without distinction." 1 Thus the democratic economic constitution produced, as its necessary corollary, a perfect political democracy.

But with the progress of accumulation the social constitution underwent a radical change. The master workman was converted into a non-labouring capitalist, and the journeyman was transformed into a wage earner. The economic equality formerly existing between the two elasses was succeeded by the domination of one class over the other. The bourgeoisie separated themselves from the common people and became the capitalist class, while the labourers were forced into a position of economic dependence. To arrive at this result a double struggle was necessary. On the one hand, it was essential to exclude the working class (which had had a large share in the government of the towns during the corporative régime) from political power; and on the other hand, it was necessary to dispute political sovereignty with the feudal elass, which had retained its ascendency in the General Assemblies and in the government of the State. The energy and slitl of the bourgeoisie showed themselves very strikingly in this twofold contest.

In proportion as their wealth and economic power increased, the more successful were the attempts of the hourgeoisie to exclude the people from all shate in the government of the towns. During the sixtecnth, and even to the eighteenth century, municipal history is but an account of successive reductions in popular privileges and the increasing suceess of the oligarchy. During the fifteenth ecntury in France, as we have said, the general assemblies of the towns were composed of the entire population. Toward the end of the seventeenth century such representation was a rare oceurrence, and in the eighteenth century the people ceased to comprose the Parliaments. 'Thus the assemblies being no longer elected by the masses, no longer reflected their will. Berywhere the atssemblies were now made up exelusively lirom the notables, sone of whon had 
seats in their own right, while others were the representatives of corporations or privileged companies. The further we advance the more we find the number of notables in their own right increasing and the number of representatives of industrial corporations falling off. Finally the assembly was made up entirely of the bourgeoisie, and artisans were refused admission to its deliberations. Moreover, the mayor (if the office were elective) could only be chosen from among the principal notables. Thus the government of the towns became oligarchical in character, and the idea of excluding the people from political rights inspired all municipal legislation from the reign of Louis XI. to Louis XV. ${ }^{1}$

The political supremacy of the bourgeoisie naturally had its immediate effect upon the system of taxation, for the taxes that the bourgeoisie established in the towns fell principally upon the popular classes. "The bourgeoisie of the towns," as Turgott sagely remarked, "have found a way of so regulating the octrois that they do not fall on their own shoulders." A like exclusion of the labouring classes from economic and political power was effected at the same time in England. "The effect of these measures, coupled with the gradual decline of the old English yeomanry, the substitution of tendency at will for leases, the indiscriminate allowance of outdoor relief, the cnclosure of commons, and several other causes, was to impair fatally the spirit and capacity of selfgovernment in rural districts. Such a revolution may have been to some extent inevitable, and partially compensated by greater national unity. Still the fact remains that by the reign of IVilliam IV. the descendants of free holders, who once sat as judges and legislators in the courts of their own country, hundred and township, had sunls into day labourers but one degrce removed from serfdom." 2

Along with this economic separation of the bourgeoisie from the people and the political' supremacy of the former in the sovernment of the towns, the situation of the third estate in

${ }^{1}$ De 'Tocqueville, loc. cit., pn. 60-62, 358, 380, 139.

2 Brodrick, "Local Government in Engiand," in the Cobden Club Essays, 1875, p. 23. 
the general assemblies underwent important modifications, and although bourgeois deputies still continued to deplore the miseries of the labourers, their proposals were much more moderate. Thus in France, in the States-General of 1484, the bourgeoisie no longer offered, as in 1357, a new system of administration, but limited itself to proposals for a reduction of taxes, the suppression of abuses in the collection of the taille, and the repurchase of the alienated portions of the royal demesne. And in the States-General of 1588 we find the third estate (though its representatives still expressed their interest in the condition of the labourer) far less differentiated from the other two orders than was the case in preceding assemblies. In fact the third estate had by this time substantially changed its nature. It was no longer the order which stood for the bourgeoisie, the freemen and the serfs, or, as Baron de Sénecey scornfully expressed it, an "ordre composé du peuple des villes et des chumps, ces derniers quasi tous hommagers et justiciables des deux premiers ordres, ceux des villes, marchands, artisans, fils de cordonniers et de savetiers". It was now composed exclusively of rich bourgeois who bought with money the offices which exempted them from taxation, even as they had already freed themselves from military service through their wealth. They were henceforth on a plane of equality with the nobles, as they were now idle owners themselves, all-powerful in the towns as the nohles were influential in the country, and only excluded from effective participation in the government of the State by their minority representation in the general assemblics.

After the bourgeois capitalists had consolidated their political forces and excluded the lahourers from the local government of the towns, it only remained for them to complete the second half of their programme and break down the political prerogatives of the aristocrats. The hourgeois' political revolt against feudalism accordingly followed close upon their political reaction against the labourers.

This strugghle between capital and the fief was profoundly different in character from the contest described in the freceding chapters between profits and rent. The antagonisn 
between profits and rent is an antagonism between two revenue classes both of which share in political power, and contend together for political superiority. This struggle belongs to the normal periods of political evolution, and in no way prepares for the dissolution of an existing social system. It is, on the contrary, the product of stable conditions; so much so that all antagonism between these two revenue classes ceases the moment the existing social system is in any way threatened. The conflict between the bourgeoisie and the nobility, on the other hand, presented a very different character. It broke out at a critical period of political evolution, and was the result of a particular process of social decomposition. The new revenue form excluded from political power fought in this case to wrest the sovereignty from the class controlling the revenues of the preceding system, and still maintaining its monopoly in the government of the State. The conflict between rent and profits is, moreover, permanent in character and embraces cvery historical period of social evolution; while the struggle of the new revenue form against the political monopoly of the holders of the old is a transitory phenomenon peculiar to the period of revolutiorr. The antagonism between profits and rent displays itself in the silent conflict which goes on day by day but never modifies the essence of the political constitution; while the battle between capital and the fief was begun by an open revolt and ended in political metamorphosis.

If we compare the insurrections of the communes against the fiefs with the revolt of capitalistic property against the political power of feudalism, we find that both political movements present the same appearance, because in each case personal property measured its strength against landed property. ${ }^{1}$ But this apparent resemblance hides a profound difference; for the very nature of the revenues, and, consequently, the political

${ }^{2}$ In the struggle between the communes and the fiefs personal property and real property alone were engaged; while in the course of the contest between the bourgeoisie and the nobility, the landed property of the bourgeoisie-in so far as it existed-allied itself with personal property in its reaction against feudalism. 
systems, were essentially different at these two epochs. In the early economics of the middle ages we may search in vain for wage labour, because the conditions that make for the wage system (the necessary corollary of the modern capitalist system) were entirely lacking. IVe only meet with a class of independent artisans who were paid for their work, and a class of landed proprietors whose revenues were derived from the subjection of their labourers. The struggle between the communes and the fiefs was thus in no wise a contest between capital and landed property, but a revolt of independent labour against feudalism. lnasmuch as the lack of an automatic capitalist rérime and the absence of a wage-earning class made it necessary to accord personal sovereignty to the landed proprietors, this political struggle between personal and real property could not well result in wresting jurisdiction from the landed proprictors. Thus the contest only succeeded in checking such excesses on the part of the feulal lords as worked injury to the industry and commerce of the towns. For this reason, the incessant conflict between personal and real property during the middle ages never resulted in a decisive victory for either side, hut perpetuated itself in a series of indecisive strugghes, whose nct result was to limit the rights of rapine and warfare maintained by the feudal classes.

It became very different, however, after capitalistic wealth and the wage system were introduced, when rural serfdom disappeared and when economic equality no longer prevailed in the towns. The very existence of at wage-earning class made the personal jurisdiction of the landed proprictor entirely superfluous. His continued autlority was thus a mere survival of an antiquated economic system, and a form of usurpation no longer required by the organic conditions of society. The capitalist class, accordingly, took it upon itself to brealk down the political power of landed property, and the old conflict between personal and real property was renewed under an entirely different form. Personal property was no longer represented by independent artisans, but by capitalists, bankers and entrepreneurs; and the struggle between the two forms of property, instead of continuing its old indecisive course, resulted 
in definitely dissociating landed property from the personal sovereignty which had up to this formed its historic attribute.

In most of the nations of Europe the abolition of the personal sovereignty of landed proprietors was accomplished several centuries after the struggle between the commune and the fief, and was marked off from this earlier conflict in a very definite way. But there was one country in which these two struggles were merged, and, in this particular case, it is somewhat difficult to fasten on the instant when the bourgeoisie conquered political power. It was in Italy that this exception to the normal development of capital occurred. In the other countries of Europe the conflict between the commune and the fief wore itself out in a succession of fruitless struggles in which neither party gained a decided advantage; but in Italy the bourgeoisie of the towns was soon poiverful enough to vanquish the feudal lords on the field of battle. The latter, deprived of all political privilege and seigniorial jurisdiction, were then compelled to choose their domicile within the victorious towns and submit to their laws. ${ }^{1}$ Thus, by a sort of historical crasis, the disjunction between landed property and personal sovereignty was effected in Italy as the result of the earlier conflict between the commune and the fief. A very remarkable result followed from this precipitate development. The Italian bourgeoisie, precociously victorious, wrested jurisdiction from feudalism at a time when such jurisdiction was still essential to the maintenance of the revenues from landed property. Thus although the Italian bourgeoisie was able to vanquish the feudal lords, it could not modify the economic conditions which rendered individual political authority necessary on the landed estates. But the sagacity of the victorious bourgeoisie was equal to the occasion. They robbed landed property of its sovereign jurisdiction, but at the same time they re-established the restrictions necessary to guarantee the evenues by a law regulating the rights of the agricultural arfs. The prohibitions on the emigration of the serfs and

${ }^{1}$ See for example, Sismondi, History of the Italian Republics, chap. xxv. Ferrari, Histoire des révolutions d'Italie, Paris, 1858, i., pp. 219-49, ui., p. 165 , etc. 
the determination of their rents and dues, formerly imposed by the landed proprietors, were now established by the town authorities. ${ }^{1}$ In short, the moment the towns mediatised the feudal lords they provided by law for the maintenance of the very restrictive dispositions whose economic necessity had originally occasioned seigniorial jurisdiction.

The victorious party which accomplished the political defeat of Italian feuclalism was made up of the burghers, but not capitalists, because the capitalistic economy, founded upon the wage system, had not yet appeared upon the horizon of history. It was not until a later period that the automatic capitalistic economy developed in Italy. The bourgeoisie then became divided into the two classes of entrepreneurs and wage earners, and following this later cconomic differentiation, the capitalist class finally gained possession of political power by disfranchising the labourers. Hence we note a peculiar development in Italy, presenting a strange contrast with the other nations. In other countries the differentiation of the bourgeoisie into a capitalist and a wage-earning class, and the former's absorption of the monopoly of governmental authority, preceded the political victory of the bourgeoisie over the feudal lords. In Italy, on the contrary, this political victory over feudalism and the suppression of seigniorial jurisdiction preceded the differentiation of the bourgeois class and antedated the economic and political ascendency of capital."

An important conseyuence flowed from this fact. In Italy, where the non-feudal class was composed of artisans and labourers, the hourgerisie formed a compact mass, and feudalism fell belore the impact. Anong the other European nations, however, the bourgeoisic entered into its contest with the fief, a divided class. In these cases it wals not, therefore, the entire mass of non-feudatories which precipitated itself against feudatisn, but sometimes one of the two bourgeois factions and sometimes both, according as there was antagonism or harmony between them in this matter of disputing the political supremacy of feudal property. On this account the

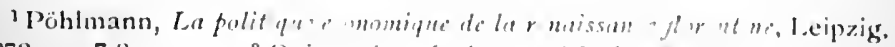
1878, pp. 7.8 .

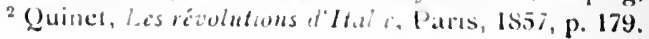


bourgeois revolt shows striking differences both in character and in efficacy in the different European countries, according as capital alone raised the standard against the fief, or associated the working people in its rebellion. From this point of view we are able to perceive the real differences between the several bourgeois revolutions fought out in the different European States.

Germany, England and France are the classic lands of this revolution. Thus the political commotions in Germany at the time of the Reformation, the Englisin Revolution of 1688, and the French Revolution of 1789 , all three constituted the political fulfilment of the preceding economic transformation giving the capitalist-bourgeoisie its dominant position. But in these three revolutions essential differences existed which have thus far been overlooked. In Germany, capital found itself in a position of hopeless inferiority against feudal property, and having to rely entirely upon its own resources in its contest with feudalism, it attained but incomplete success. In England, however, the capitalist-bourgeoisie early acquired great wealth, and soon succeeded in limiting the powers of the nobility. Thus by the time the bourgeoisie clecided to definitely possess themselves of political sovereignty, they found themselves confronted by a weakened adversary, and they were thus able to gain the victory over feudalisn 1 alone without invoking the aid of the people. Hence nobles and capitalists formed the principal figures in the drama of the English Revolution, while the people remained indifferent spectators. In France, on the other hand, the bourgeoisie never attained sufficient wealth and power to allow them to restrain the excesses of the nobility. The nobles, therefore, opposed a vigorous resistance to the political demands of the bourgeoisie, and the latter found themselves accordingily compelled to seek an alliance with the people. As compared with the English Revolution, the Frehch Revolution, therefore, presents a strikingly popular character.

Let us examine into this contrast a little more closely. Nothing places greater obstacles in the way of a study of this kind than the habit common to so many historians and publicists of 
regarding the political events of a certain epoch as the outcome of the will of the sovereign. These men seem to forget that a man is only king because other men consent to the arrangement, and that this consent is simply based upon the fact that the sovereign's exercise of political power accords with the interests of those who lend hin their support. Consequently, as a moving cause behind the policy of the most despotic monarch, there always stands the interests of the dominant proprietary classes. These preliminary observations may be directly applied to the great social conflict between the nobility and the bourgeoisie; for the acts of the sovereign power in debasing the nobility-ordinarily regarded as a spontaneous expression of central authority tending toward consolidationsimply represent the means employed by the bourgeoisie in weakening the power of the aristocracy. If we are content with appearances, it was the ling who triumphed over the nohility; but, as a matter of fact, the monarch could not have made a single move in this direction without the support of the bourgeoisic, and it was only the latter's growing power that inpelled the sovereign to continue his struggle with the nobility. Or, to put it more directly, it was really the bourgeoisie which measured its strength against the feudal class, and the monarch was simply the instrument employed to destroy the power of the nobility.

Direct prool of this is to be found in the histories of the three above-mentioncd countries, where the political power of the bourgeoisie first became apparent. At the beginuing of the eightiteenth century capitalistic wealth was already highly developed in Germany, though it had not yet reached the point attained in England and France. Commereial companies were trading with the East and the West Indies, and the great banking house of the laugsers trafliclied in the sale of indulgences. So great, indeed, was the power of this house that it inpeded the religious movement then making toward a disruption of the existing relations hetween Germany and Rome. But this same bourgcoisic, whose power was thus increasing, was still excluded from political power, or at best enjoyed but nominal participation in the assemblies of the 
States. Political power was then concentrated in the hands of a small fraction of the feudal class, the electors; while the other feudatories, namely, the lesser nobles, remained practically excluded like the bourgeoisie. The political power of the lesser nobility continued to decrease with their increasing impoverishment, following the depreciation in the value of landed property and the growth of luxury. Looking at it in this way, we arc not surprised to find that the Diet of Worms (1521) sanctioned the state of things thus rendered necessary by economic conditions, and consolidated the power of the higher nobility by excluding the nobles of the second degree from all share in the government of the State. During the following year the dominant nobility passed a series of laws distinctly hostile to capital, interdicting all commercial companies possessing a capital of over 50,000 florins, and taxing commerce by a general system of import and export duties. ${ }^{1}$ The lesser nobles first raised the standard of revolt against this tyranny of the princes, and Sickingen, the romantic hero of declining chivalry, gathered about him all the vassals in rebellion against the regular régime. But he fell before the princes in alliance with the towns, and with him died anarchic feudalism and its irregular authority. Encouraged by this success, which destroyed for ever the military dictatorship of the feudal class, the bourgeoisie then began to offer vigorous resistance to the legislation restricting capital. A legion of unproductive labourers, "literary parasites, scribblers and pamphleteers," as Janssen calls them, aided them in their revolt. They despatched ambassadors to Charles V. in Spain, and through the influence of gold and with the help of the Fuggers, they obtained from the emperor the revocation of the obnoxious laws. This was the second triumph for the bourgeoisie, but they never went any further. Though deprived of its original rights of warfare and rapine and held in check by the emperor, the feudal class in the person' of the princes nevertheless preserved its political monopoly, which could only be taken from. them by some great revolution. But without the aid of the people the bourgeoisie was unable to effect a revolution of such

${ }^{1}$ Janssen, Geschichte des dentschen Volkes, Freiburg, 1882, ii., p. 229. 
magnitude. They dared not seek such an alliance, however, nor were they willing to accept it when voluntarily offered. In the country districts the unfortunate labouring people, tortured in martyrdom for ten centuries past, finally arose in rebellion against the usurpations of the feudal lords. Urged on by the impoverished clergy, and eager for vengeance, they burned the castles of their lords, and swore that hencefortin only the cottages of the poor should be seen upon the earth. During the revolution that followed some of the towns offered unlooked-for assistance to these political uprisings, and made common cause with the peasants. Strasburg received the rebels as citizens, Ulm provided them with money, and Nuremberg supplied them with provisions. A learned man, Conrad Mutian, declared that the revolt proceeded more from the towns than from the country, and the bourgeoisie and the people appeared, for the time, to fraternise in a joint attack upon dominant feudalism. But the capitalists suddenly drew back and, discarding the willing support offered by the cultivators, made an alliance with the enemy. The towns then lent their strong support to the feudal lords in their struggle with the agriculturists, and Luther himself, the pontiff of the bourgeoisie, condemned the rebellion, denied the claims of the peasants, and proclaimed the legality and sanctity of serfdom. This change of heast was the salvation of feudalism. The revolted serfs on their side, lacking the discipline and guidance of the bourgeoisie, went to horrible excesses, which reached a climax in the savage communism of the Anabaptists; while, on the other hand, the feudal class, strengthened by the alliance, or at least the neutrality, of the bourgeoisie, consolidated the foundation of their political power, and cemented their authority with the blood of the agricultural population. Thus, having refused to accept the proffered popular alliance, the German bourgeoisie saw the political power they had been on the point of possessing escape from their hands. For several more centuries, accordingly, sovereignty remained a special privilege of the feudal class, though it continued to be modified and adapted to the new times. ${ }^{1}$

${ }^{1}$ Ranke, Dentsche Geschichte im Zcitalter der Reformation, 6th ed., Leipzig, 1881, i., pp. 206-321 ; ii., pp. 31-149; iii., pp. 375-77. 
The bourgeois insurrection against the nobility in England had a far more glorious outcome. At the time of Henry l. the English bourgeoisie was powerful enough to render valuable aid to the sovereign in his struggle with the feudal lords. Still, this early alliance between the monarch and the bourgeoisie was not yet strong enough to weaken the power of the nobility ; for the nobles at once united in opposition and imposed a new constitution upon the king, that was exclusively to their own advantage, and under which the bourgeoisie had no representation whatever. But the increasing wealth of the commercial classes, and the progressive impoverishment of the nobles-which made it necessary for them to dispose of a portion of their lands to the owners of capital 1 -compelled the nobility at last to assent to the admission of the bourgeoisie into Parliament; for it was impossible to subject this new wealth to taxation without according it a right of representation. The English bourgeoisie on entering Parliament in 1295 found itself, however, in a hopeless minority as against the feudal class which still preserved its political power. It is true, the lesser nobles-the lnnights-soon severed their connections with the upper nobility and united with the towns-a remarkable result of the antagonism we have already observed between large and small holdings. But even this coalition between the lesser nobility and the towns would have remained ineffectual against the great barons had not the famous Wars of the Roses occurred. This war was the suicide of the British nobility, as the feudal lords came out of the struggle weakened and almost ruined. The forces of the capitalist class were, on the other hand, enormously increased, and tended more and more to counterbalance the influence of its feudal rival. From this time on the English Parliament presented the interesting spectacle of a contest between two equally matched parties, each of which succeeded in turn in acquiring ascendency over

1 "The nobles of England," wrote Danicle Barbars, Ambassador of the Republic of Venice, "ruined in their possessions, burdened with enormous expenses, and without money, can rarely become wealthy, and are often enough compelled to sell their paternal heritage" (Relazioni slegli Ambasciatori Veneti, Älberi edition, first series i., vol. ii., p. 261). 
the other, until the capitalist class, gaining in strength through its economic development, succeeded at last in overcoming the feudal lords in the great revolution. ${ }^{1}$

During the period of their ascendency the nobility practised economic and political tyranny, and turned the legislation of the time in favour of the landed proprietors. Thus, during the reign of the Stuarts, the nobles passed protective laws to their own advantage and combated the infant industries of the day. The bourgeoisie reacted, it is true, not, however, through parliamentary procedure, for from such means they were precluded by their minority representation, but through the instrumentality of Elizabeth, who took the side of the merchants against the nobility. This bourgeois legislation stirred up a spirit of revolt against the monarch among the aristocrats who rallied around Marie Stuart. Marie was beheaded, and in her death the bourgeoisie celebrated their first victory over the aristocracy. The aristocratic party regained confidence, however, with James I. and Charles I., under whose governments legislation once more turned in favour of the feudal proprietors. But the bourgeoisie executed Charles I., the feudal king, and acquired new power under Cronwell. In order the more effectively to oppose the still imposing ranks of the aristocrats, the English capitalists were, however, themselves compelled to erect a powerful centralised government, which, following the normal law of history, ultimately reacted against them; for Cromwell, not content with casting heavy burdens of taxation upon the nobility, also held the bourgeoisie in check and ameliorated the condition of the lower classes. The capitalists naturally chafed under such restraint and made it the oecasion of their indifference toward the new Government, which, lacking

${ }^{1}$ Stubbs, Constitutional History of England, the edition, Oxford, 1883, i., pp. 339, 483, 581, ff.; ii., pp. 196, 319. During the W:ars of the Roses both the rival parties sought the support of the towns, but by employin: the alliance in their own interests they gradually placed the lalance of power in the hands of the Commoners. The nobility as a body was als:o compelled at times, on account of its own weakness, to invole the aid of the hourgeoisie in their struggles with the sovereign. The Count of Leinster had to do so in his difference with Henry III. (Buckle, History of Civilisation in England), ii., p. 313 ff.; iii., p. 12 ff. 
the support of capitalistic revenues, fell at the first blow. Monk, himsclf a large landed proprietor, restored the Stuarts, and feudal lesislation was reintroduced. But the capitalists were now ready to enter upon a really decisive struggle, and accordingly took their stand in the "glorious revolution". In this contest the small proprietors and cultivators, the Roundheads, found themselves brought face to face with the clergy and the Crown, the Cavaliers. The former were victorious, and raised to the throne of England a son of commercial Holland, IVilliam of Orange. The revolution thus signified the political triumph of the bourgeoisie. Traders, brokers, bankers and speculators were carried into power with the new dynasty. The monarch created joint-stock companies and granted them subsidies and privileges. Industry was favoured -in a word, the new revenue form was triumphant. It is to be noted, however, that this triumph was effected without any intervention on the part of the labouring classes, who, far from finding themselves benefited by the revolution, lived to see their economic bondage increased through the subsequent expansion ố capital.

The bourgeois revolution of France presents a very different character. The growth of the wealth and power of the French bourgcoisie was too limited and too gradual to allow them to combat the nobility with any vigour. In spite of the fact that the kings of France, after Louis IX., chose their ministers from the bourgeois class, and limited the pretentions of the nobility, they never pursued this policy to the point of ruining the aristocracy. The power of the French nobility is clearly shown in the war of the Fronde and the conflict between the Catholic and Huguenot nobles which culminated in the bloody massacre of St. Bartholomew. Both these struggles were simply fanily quarrels among the nobility, and, like all such divisions in the dominant class, reveal the solidity of the base upon which their power rested. The inability of the French bourgeoisie to overcome the nobility was demonstrated still more completcly by a fact of singular importance. In England the representatives of the towns united with the other two orders in proposing sanguinary measures against the peasants 
who revolted under IVat Tyler; but, in France, the small bourgeoisie, led by Etienne Marcel, contracted a fleeting alliance with the rebellious Jacquerie. Thus in the one country the bourgeoisie was able to dispense with the help of the people, while in the other a popular alliance was necessary. ${ }^{1}$ The inherent weakness of the third estate of France appeared in a still more marked manner in the States-General of 1614 , where the coalition of the two higher orders succeeded in so neutralising the efforts of the third that, one fine day, the deputies of the bourgeoisie found the doors of the hall of the National Assembly closed in their faces. Thrown back on their own resources, the third estate then recognised that they would never be able to overcome the feudal lords without seeking the aid of the people; and it was the task of 1789 to frame this alliance.

In the assembly of 1789 the deputies of the third estate belonged exclusively to the bourgeois class, and consisted of lawyers, notaries, wealthy merchants and the like. They represented the capitalists, but not the labourers. A journal of the period remarked sadly upon this exclusion of the people from the National Assembly as follows: "When we turn our gaze from these assemblies to the rest of the people who fill the streets, the squares, the market-places and the shops, and who apply themselves patiently to their hard daily toil, we ask ourselves whether, under the new order of things being prepared for us, these poor wretches, who dare not even approach the halls of assembly, will remain thus impoverished and always be in servile dependence upon the rich. And who among us can tell whether a hourgeois despotism may not suceed the rule of this pretended aristocracy?" On comparing the reports of the proceedings of the third estate in 1614 with those of 1789 ,

${ }^{1} C f$. Stubbs, loc. cit., ii., pp. 4No sl, with llichelet, Histoire de France, iv., p. 282. This difference between the lirencl St:te, essentially aristocratic in character, and the British State, which was already coming to be dominated by the hourgeoisic, soon showed itself also in the language of the respective countries. From this time on the English, looking at the matter from the point of view of the citizen, called the tax a duty; while the lerench, regarding the question from the standpoint of the State, called it a droit. 
we see with regret that all feeling of solidarity between the bourgeoisie and the labourers had by this time disappeared, and that this same bourgeoisie, whose representatives in the preceding assemblies had so eloquently denounced the miseries of the people, now uttered but timid accents in their defence, and reserved all their energies to freeing themselves from aristocratic domination and establishing their own political independence. The deputies of the States-General were assembled for three months before a single word was spoken in favour of the rural population, which was then reduced to even greater misery. It was only then that the proposition was offered to institute a fourth estate, an ordre des campagnes, that the working people might be represented in the sovereign assembly. ${ }^{1}$

But finding themselves in the minority in the States-General, and recognising that decisive action on their part against the nobility and the Crown would be impossible without popular support, the bourgeois capitalists finally encouraged the people to revolt. ${ }^{2}$ Withdrawing from Parliament the bourgeois reaction then descended into the streets and became a revolution. It was a comparatively easy matter to instigate the people to revolt, as they were already aroused by the sinister effects of famine which had come to prevail on account of the intolerable methods of production, and the inability of the revenues excluded from political power to organise agricultural and manufacturing enterprise on a rational basis. Other influences contributed no less strongly in arousing the French people to action. On the one hand, there was the activity of the unproductive labourers of the ancient regime,

'Very valuable data on this subjcct, drawn from the Archives of Paris, are to be found in Karcew's remarkable book, unfortunately very little known in the western world. See N. Kareew, Les paysans et la question agraire en France, dans le dernier quart dn xviiie siecle, Moscow, 1879 , pp. 343 , 392, and App., 1xi., 1xli.

${ }^{2}$ Neither peasants nor labourers led the proletariat rcvolt of 1789; the leaders wcre always lawyers, doctors, or men of letters, like Marat, Saint-Just and Robespicrre. Cathelimeau was the only proletariat leader of the rebels, and he was a Royalist, chef de la Vendée, i.e., a reactionist (Lombroso, loc. cit.). 
the priests, who were now become poor and hostile to the old property system; and, on the other hand, there was the agitation conducted by the unproductive labourers of the new régime, the paid thinkers of the bourgeoisie, who furnished an ever increasing stock of arguments of a more or less literary character to direct against the nobility. ${ }^{1}$

Taking everything together, it is, therefore, not surprising that a popular uprising fanned by so many influences should have burst forth like an explosion. The people were responsible for the events of the fifth and sixth of October. It was due to the populace that the king was circumvented in his flight and brought back to Paris. Under the pressure of this great. popular excitement, the sovereign was placed under the protection of the bourgeoisie and the now powerless nobility. In fact, during all the long period required to accomplish the defeat of the court and the nobles, the bourgeoisie and the people fought under the same standard. But when the court was finally vanquished and the aristocracy overthrown, and after all the obstacles in the way of the political domination of the capitalist class had been removed, "two parties appeared in the third estate," and the bourgeoisic suddenly separated themselves from the people, who had up to this rendered them such valuable aid. From this time on the bourgeoisie ceascd to be a revolutionary hody, and, instead of continuing a futile struggle against an enemy that had been disarmed, they began to lay the foundations of their own political power. But the people, whom the bourgeoisie had aroused and excited to action

${ }^{1}$ To those who still repeat the everlasting commonplace that the French Revolution was the work of the encyclopedists - without rellecting that the theories of these writers can only be explained as products of the environment in which their authors live!-we recommend the following passage from an impartial writer: "The six years preceding the Revolution were peculiarly shameful for the men of letters. It is dificult to fathom the degree of infamy to which these men who nade a business of writing were willing to desecnd. Philosophy, mathematics, the drama, romances, journalism, in fact all branches of the human intellect, were engrossed by the encyclopedic monopoly. At the root of their ideas there was nothing but vanity and wealth" (Buclicz and Roux, loc. cit., xii., pp. 3.4). 
against feudal privileges by holding out to them the hope of a better future, continued the Revolution on their own account, combating every privilege and opposing all authority, whether in the person of the Crown, the nobility, the clergy, or the bourgeoisie. Thus ' 89 became '93; the bourgeois revolt gave place to a popular revolution; and the people began to pillage the estates of rich bourgeois proprietors as well as the chateaux of the nobles. It was no longer simply the aristocracy of birth the people were combating, but the aristocracy of wealth as well. Thus the capitalist class shared the same fate as the cruel Phalaris, who perished, it is said, in the heated brazen bull he had made to burn the victims of his tyranny.

The bourgeoisie thus occupied two positions during the great Revolution. They destroyed the existing political constitution, they abolished the hated privileges of the nobility, and they battered a breach in the financial system that stood as a rampart about the political structure. But after having overridden privileges, proclaimed liberty and equality before the law, and led their struggle with the champions of the past to a successful issue, the bourgeoisie engaged in another desperate battle to consolidate their political power and exclude the labourers from authority. At the very moment when a seat in the assembly ceased to be a prerogative of birth, it became a privilege of wealth. And this was not merely for the vain glory of the viciorious bourgeoisie but because political authority was regarded as an essential guarantee of property; and because, as a historian of this period justly remarked: "Si on accorde à la majorité des individus d'une nation le pouvoir de faire les lois, et que cette majorité n'ait rien elle usurpera légalement.". To avoid this serious danger a law (which we have already mentioned) was passed restricting the right to vote to citoyens actifs; and, in October, 1789, the law of the marc d'argent declared only those eligible to the National Assembly who paid taxes amounting to a marc. "A coalition of all the aristocrats," wrote Loustalot, "vehemently opposed any change which aimed at depriving the rich of their right of becoming members 
of the legislative body. The aristocracy of wealth was sanctioned by a national decree."

Bourgeois finance, exempting the rich from taxation, then succeeded the feudal financial system that weighed so heavily upon the roturiers. As early as 1737 a royal decree assessing the rich in proportion to their incomes met with a refusal from Parliament, and the reason for such action was well recognised by the men of the time. The anonymous author of the Catéchisme des Parlements (1788) thus apostrophised the members of Parliament: "Do you think the people do not see that you refuse to levy these taxes simply because you would have to pay them yourselves?" The bourgeoisie then endeavoured to renew the old immunities from taxation in their own interests. Instead of being paid out in fabulous pensions to the old aristocrats, the public wealth now came to be squandered by a set of financiers, bankiers and brokers, whose shameless speculations made the historians of the period declare that money had talsen the place of patriotism.

The new plutocracy controlled the towns and the country, and assumed the privilege of recruiting the army ; forming, at Nirabeau's suggestion, a garde bourgevise, which quelled the rebellion of the famished population in the country districts. But this was still not enough. Every association or union of working men organised with a view to raising wages was forbidden, and when journeymen tailors and domestics out of employment gathered to the number of 3000 before the Louvre they were dispersed by the troops.

The split between the hourgeoisie and the people was now complete and irrevocable. As a patriotic writer remarked: "Misunderstandings are increasing, and the differences between the two parties, the bourgeoisie and the prople, have already led to an open rupture". A cleputy expressed himself thus in the National Assembly: "It is necessary to malie a distinction between the two classes of citizens dwelling in Paris: there are those who gain their daily bread by the sweat of their brows, and those who live at their ease. We must persuade the former of their sense of duty and restore confidence to the latter." "These burned chateaux, these 
pillaged estates, these ransacked farms-all this ruin," another deputy declared, "is the result of the war of the poor against the rich. The assembly should put a stop to it." 1

It was too late. The sleeping lion that the bourgeoisie had aroused would no longer listen to the voice of his keeper and sprang upon him. The Legislative Assembly, composed of bourgeois representatives and higher employees, gave way to the National Convention, in which the people, represented by the Montagnards, gained the ascendency over the bourgeoisie, represented by the Girondino. The latter finally succumbed. This was great good fortune for the proprietors, for the Convention was now occupied for some time with its process against the king and its wars with Europe. These preoccupations diverted the attention of the people and their assembly from the revolutionary measures they would otherwise have insisted upon. ${ }^{2}$ Indeed, the king had scarcely been beheaded before Rabant proposed in the Chroniques de Paris (January, 1793) the equalisation of wealth. ${ }^{3}$ At the same time, the Society of the Friends of Liberty proposed the following decree with the authorisation of the Government: "The Convention invites the poor to take advantage of this opportunity to declare war upon the rich and re-establish order at any price".* The Convention, for its part, was not long in deciding upon a system of taxation to equalise wealth. Under the transparent euphemism of "forced non-interest bearing loans," a progressive tax was introduced in the month of January, 1793, that in reality confiscated all incomes over 9000 livres. The

${ }^{1}$ Buchez and Roux, loc. cit., i., p. 254 ; ii., p. 214. An article entitled "Riches et Pauvres," published in the Révolutions de Paris in the month of January, 1791, says : "Ce sont les pauvres qui ont fait la révolution, mais ils ne l'ont pas faite à leur profit, car depuis le 14 juillet ils sont à peu près ce qu'ils étaient avant le 14 juillet". And it adds, with somewhat too naturalistic phrascology: "Le fumier, qui fait pousser de très beaux fruits, doit être rejeté lors qu'il pue" (ibid., viii., p. 422).

${ }^{2}$ Saint-Just himself declared before the Convention that social reforms had been hindered by the wars against the powers and the aristocrats (Esquiros, Histoire des montagnarls, Paris, 1847, ii., p. 380).

3 Buchez and Roux, xxiii., p. 466. 248.

4 Pagès, Histoire secrète de la révolution française, Paris, 1798, iii., p. 
French Assembly was under no illusion in regard to the opposition the bourgeoisie was likely to make to the application of a law to "ramener à l'áqalité, par des voies douces, les furtunes qui en étaient sorties"; and for this reason they confided the execution of the law to a jury composed of officers of the central administration and six or eight citizens chosen from the tax-payers of districts which were not affected by this particular tax. ${ }^{1}$ We can gather from this that, in order to bring the bourgeoisie under the execution of the law, it was necessary to exclude them from legislation and administration.

But the Reign of Terror betrayed the effervescent character of the political power of the proletariat. It simply represented the temporary dictatorship of the labouring class at a stage when economic conditions rendered any system of social equality impossible. It was the product of an antithesis between existing economic conditions and the political aspirations of a temporarily dominant class which, unable to gain its ends by legislative reforms, abandoned itself to mad violence. The existing antagonism between political sovereignty and economic conditions gave rise to such painful contrasts, that a reaction was bound to set in toward some political system better adapted to the prevailing economic terms. It was, therefore, but natural that the frightful excesses of the Reign of Terror so soon called forth a vigorous protest on the part of the bourgeoisie. It resulted, in fact, in the Revolution of Thermidor, which re-established the supremacy of the proprietary class.

Thus the capitalistic revenue-holders, after successfully destroying the political supremacy of the feudal proprietors, next overcame the popular classes that originally lent them their support. By this double victory capitalism established its absolute dominion."

Stourm, loc. cit., ii., pp. 376-81.

2 We must accordingly attribute wonderful inventive genius to $M$. de Molinari, for, after having explicitly aftirned the cenomic basis of politics, this author alds that this principle only applies to past epochs, and is no longer true under present conditions, because the French Revolution disturbed the normal equilibrium between the economic and 
Important consequences nevertheless resulted from this temporary intervention of the labourer in the affairs of the French Revolution, because it compelled the bourgeoisie to tolerate a political system which benefited a portion of the popular classes. In order to resist the popular despotism of the Reign of Terror, and at the same time discourage any further attempt on their part, the nobility and adherents of the ancient régime, the bourgeois class (and the more so because it was composed in part of a number of small proprietors) was itself obliged to establish an equally despotic government, which, though constituted by the bourgeoisie, soon reacted against them. Thus just as the British Commoners were compelled, in order to offer effective resistance to the nobility, to place themselves under the dictatorship of a Cromwell, so the French bourgeoisie, in order to make sure of their victory over the nobility and restrain the still rebellious populace, were likewise obliged to confide the sceptre of power to the hands of an absolute monarch who soon made them feel the burden of his tyranny. By his wars Napoleon benefited the people, for wages rose as the supply of labour diminished; but on the other hand, his taxes, the continental blockade, the set-backs to commerce and credit, and the duties on beverages, ${ }^{1}$ halfruined the bourgeoisie. We can readily understand how a sovereign of this character, whose efforts were all directed towards re-establishing the former despotism, must sooner or later provolie a reaction on the part of the bourgeoisie, to whom such absolutism was abhorrent. Thus after the nobility had been subdued and the populace repressed, as soon, that is, as the causes making it necessary to put up with an absolute

political systems and forcibly established a political constitution that fails to correspond to modern economic conditions (loc. cit., p. 423 ff.). As if the French Revolution were not itself the result of a lack of equilibrium between the political constitution, which gave the sceptre of power to the nobility, and the economic system dominated by the capitalistic bourgeoisie; and as if its aim was not precisely to put an end to this false balance by adding political sovereignty to the economically dominant class!

1 "Ce sont les droits sur les boissons qui m'ont perdu," cried Napo. leon at St. Helena. 
government had ceased to exist, the bourgeoisie turned against their own creature and cast him down. By monopolising the necessary provisions and thereby compelling Napoleon to defer his Russian campaign for six weeks, the bourgeoisie was really' responsible for the catastrophe that was immediately produced by the cold. It was the bourgeoisie again who, while the Corsican hero was giving battle to the allies on the plains of Champagne, and the results of the war were still in doubt, caused the 5 per cents. to fall to 45 francs, and thus gave the coup de grace which determined the ruin of the empire. It was the bourgeoisie who paid for Marmont's defection; it was they (the emperor himself said so at St. Helena) who compelled Napoleon to abdicate, and it was they, finally, who sold him to the English.

This weakness of the French bourgeoisie, which obliged them to call upon the aid of the populace in the great revolution, continued to be apparent at each succeeding stage of their political history. Thus when the aristocratic government of the Restoration became intolerable to personal capital, the capitalist class could only resist the oppression of the government by again contracting an alliance with the people ${ }^{1}$ and for the second time a revolt begun by the bourgeoisie degenerated into a popular revolution. But the people reaped no real advantage from the revolution, as it resulted in raising Louis Philippe to the throne, who, during the first years of his reign, almost realised the ideal of a government for property. Soon afterwards, however, the bourgeois king, profiting by divisions in the bourgeois class, transformed himself into an absolute monarch. This act called forth renewed resistance on the part of the bourgeoisie in alliance with the people and resulted in the revolution of 1848 , which, originating in a hourgeois reaction, ended in a socialistic revolt, In order to shake themselves free from their importunate allies, and remedy their political weakness, the hourgeoisie then again sought recourse in a Casar, and the second empire was established. But though, like the former despotism, an instrument of the 
bourgeoisie, the new government overrode their interests, and during his entire reign the monarch lrept perpetually vacillating between property and the proletariat, until the day arrived when the bourgeoisie, once more in alliance with the people, overthrew the empire and acquired absolute political power under the Republic, the form of government under which the political supremacy of property attains the apogee of its development.

To resume: in Germany, where the bourgeoisie could not of themselves destroy the power of the landed proprietors and dared not accept the proferred alliance of the people, the bourgeois revolution proved abortive, and feudal politics were allowed to remain in a modified form. In England, on the contrary, the relative weakness of the nobility and the strength of the bourgeoisie made it possible for the latter to possess themselves of political power single-handed, and thus effected the essentially capitalistic revolution of 1688 . In France, finally the relative strength of the nobles compelled the bourgeoisie to ally themselves with the people in order to obtain political supremacy, and this gave a popular character to the French Revolution. The popular character of this movement is, by the way, one of the main causes of the nore equitable distribution of wealth still prevailing in France. In accordance with these differences in origin, the German Revolution resulted in a semi-feudal constitution, the English Revolution established a capitalistic State, and the French Revolution introduced a popular régime. But the fief is now disappearing from Germany, and the power of the people is declining in France, so in both these countries the political supremacy of capital is gradually being established and consolidated.

Like all great social changes this bourgeois conquest of political sovereignty brought forth its opponents and defenders. Swift, the celebrated English humorist, saw with regret the forfeiture of the political rights of the landed proprietors who, in his opinion, were incorruptible judges and upright statesmen; and looked with suspicion upon the appearance of a new class of politicians, cosmopolitan in character as their wealth was proteiform, who were only solicitous of easy gain. But Saint- 
Simon, the high priest of bourgeois socialism, boldly declared that political sovereignty belonged by right to industry. "The producers of social utilities," said he, "being the only men useful to society, alone have a right to govern it. The last step that industry has now to take is to assume the direction of the State, and the great problem of our times is to assure the majority in Parliament to the industrialists." 1 The means that Saint-Simon proposed to attain this end were, indeed, singular. They consisted in letting the farmer instead of the proprietor pay the land-tax; that the former as a tax-payer might take his place among the electors. But childish as this proposal is (for it is evident that the extension of the right of suffrage to agricultural capitalists could just as well be effected directly without making them go through the useless formality of paying the land-tax), it is still interesting as a theoretical expression of the political triumph of the bourgeoisie, which was thus sanctioned by scientific dogma.

This bourgeois revolution, fought out so long ago in the more civilised countries of Europe, is now being effected under our very eyes in modern Russia. What, indeed, is the Nihilist movement at present disturbing Russia but a revolt of the capitalistic revenue-holders in alliance with the proletariat against the authority founcled upon patriarchal and collective property? The rural communities and the snall proprietors hold political sovereignty in Russia. It is upon these two pediments alone that the political power of the $\mathrm{C}$ zars reposes; while the great proprietors and the capitalists, who maintain uncontested economic supremacy, are excluded from all share in political sovereignty. Just as in days gone by the Frencl bourgeoisie was supreme in the assemllies of the towns, but excluded from all participation in the central government; so likewise in modern Russia the capitalistic aristocracy predominates in the councils of the provinces, in the zemstoos, but has no share in the central gorernment, and even finds its local treedom linited by imperial inter-

'Saint-Simon, Du sy'stime industriel, Paris, 1821, pp. 115, 117, etc. 
ference. ${ }^{1}$. This exclusion of the dominant revenues from political power prevents them from attaining their complete development and establishing means of production more in harmony with the needs of the country. This is the cause of the insufficiency of production in Russia, and more especially of agricultural production, which is still in the hands of the rural communes. Hence the terrible famines which scourge modern Russia, as they formerly (and for the same reason) afflicted France on the eve of 1789 . The poor classes bear the full burden of these periods of scarcity, and they are consequently becoming restless and turbulent. The oppressed are thus being fashioned into ready instruments in the hands of capitalists who desire to triumph. For this reason the economically dominant classes, which are striving for political power, ally themselves, on the one hand, with the unproductive labourers, men of letters, teachers, physicians and the like, whom they support; and, on the other hand, with the proletariat classes, whom hunger is torturing and driving to revolt. It is this immense congeries of human forces which is ready to precipitate itself upon the old Muscovite monarchy, founded upon a revenue system that is already upon its decline. Such is the nature of Nihilism. This dismal association which makes the prince fraternise with the mendicant in the common ideal of ruin and death; this dark Vehme, who seeks his associates anid the miseries of the isba and among the splendours of the throne, is simply the result of the insurrection of capitalistic revenue, already successful in the economic field, seeking to reap the fruits of its victory by appropriating political sovereignty. And in sinister opposition to the rage of the coming revenue-holders, who desire the power they do not possess, stands the determination of the holders of the declining revenue, equally anxious to maintain at any cost an authority which now lacks economic justification. It is not in the lea'st surprising, therefore, that this Russian reproduction of the contrast already witnessed in France between political sovereignty and economic conditions should also reproduce a new Reign of Terror, whose records

'Stepniak, La Rusșie sous les Tzars, Paris, 1887, p. $424 \mathrm{ff}$. 
are now being written in indelible characters of fire and sword in the annals of contemporary Russia. ${ }^{1}$

While the dominant capitalistic revenues of Russia are preparing the way for the bourgeois revolution, these same revenues are beginning to lose power in Vestern Europe, and threaten now to carry down with them the political system which they support. The revenues derived from the wage system approach extinction in two ways: on the one hand from the fact that they themselves tend to decline below the minimum, and on the other hand because, even before they reach this point, unproductive labour becoming less richly remunerated by property shows a tendency to break away from its old alliance with capital and unite its fortunes with the wage earners. But when the revenues from capital are annulled there will no longer be any reason for concentrating political power in any one social class, and sovereignty will then become the common heritage of all producers. Before arriving at this result, however, the very course of economic development will make for the fuller participation of the labourers in political authority. This will result from two sets of influences. In the first place the unproductive labourers who, during the period of capital's ascendency, have united in preventing the exercise of the labourer's right of rote by inducing them to elect the property-holder's candidates, will renounce this róle as soon as the falling off of capitalistic revenues begins to cut short their share, and they will then apply themselves to directing the rotes of the working classes in their real interests. Universal suffrage will then allow the poorer classes to be really represented in Parlianent and have their revolutionary demands definitely formulated. On the other hand, following the diminution in the revenues, it will become

${ }^{1}$ Does not the ruin, resulting particularly from the conpetition of Indian and American grain, that has visited the Russian proprictors since 1884 go far toward explaining the recent recurtences of Nihilistic outbreaks? As a contributing cause must also be added the great number of charges instituted of late by the Russian Government in favour of the nobility and given as the price of favours granted, hy virtue of the law of the 12th of October, 1889, to the impoverished large proprictors. 
increasingly difficult to grant the unproductive labourers a large enough share in the benefits of capital to persist in the present plan of converting the popular representatives into servants of property. Hence in due time the people's candidates will become the real representatives of their electors, and will henceforth impress legislation with a character more in conformity with the interests and wishes of the labouring classes. A new element will thus be introduced into the legislative assemblies. The political struggle between rent and profits will suddenly come to an end, and the existing schism in the capitalist class will be healed. Both factions will then unite against their common enemy. Modern assemblies will thus become divided into two radically adverse parties, and the interesting conflicts fought out in bygone assemblies between the third estate and feudalism will be reproduced in the coming contest between the third and fourth estates. But just as the bourgeoisie failed to obtain political supremacy until economic ascendency was secured, so long as the existing economic system concentrates wealth in the hands of the capitalist class, the fourth estate will likewise only constitute an increasingly powerful minority. It will never obtain political supremacy, in other words, until the natural evolution of economic relations shall have determined the decomposition of the existing caprtalist system and substituted a higher form, namely, the mixed association. The political power of labour will then be built upon a new economic base excluding all monopoly of capital. In a word, political democracy will be established as the natural and necessary result $\mathrm{O}_{\mathrm{i}}$ the coming economic democracy. "The dissolution of society bids fair to become the termination of a career of which property is the end and aim, because such a career contains the elements of self-destruction. Democracy in government, brotherhood in society, equality in rights and privileges, and universal education, foreshadow the next higher plane of society to which experience, intelligence and knowledge are steadily tending. It will be a revival, in a higher form, of the liberty, equality and fraternity of the ancient gentes." 1

1 Morgan, loc. cit., p. 552. 
This result will be hastened by the intervention of two very powerful factors. The first of these is the sudden energy to be imparted to social activity by the intervention of the labourers in the political struggle. The coming economic transformation by placing more and more emphasis upon popular influence, will threaten the very existence of the capitalists and compel them in self-defence to establish a powerful centralised government. This necessity of centralising social power in the interests of the capitalist class has, indeed, already become manifest. To be sure, in France, Switzerland and America, ${ }^{1}$ where the division of wealth is more equal and the economic contest less acute, the capitalist class is still able to maintain a comparatively free system of government. But where, on the other hand, the struggle is bitter, the bourgeoisie has been compelled to establish a stronger government to be prepared for probable reactions on the part of the subjugated class. This policy of centralisation which the bourgeoisie is being compelled to adopt, ${ }^{2}$ will, however, ultimately turn against its authors, and by limiting capitalistic rights and privileges it will hasten the political change which the present economic transformation has already rendered inevitable.

The other influence hastening the decomposition of the present political system and facilitating the recomposition of a higher form is the frightful degeneration now going on in the ranks of the bourgeois class, rendering it less and less fit to hold the sceptre of power and direct public affairs in a rational way. It was, as we have seen, the formation of capitalistic property which created the intellectual superiority of the proprietary classes and justified their political ascendency. But the dissolving influences of social differentiation have

${ }^{1}$ Even in America the people only find refuge against the political omnipotence of the corporations in the veto of the President or the Governor, and this is considered by some American writers as a step in the direction of Cacsarism (Hudson, Railzeays, p. 473).

${ }^{2}$ It is a significant fact that in Germany, Italy and even in England the political acts of the Crown have recently come to be affirmed with more energy, and the sovereigns of these countries now manifest a marked tendency to abandon the purely passive róle imposed upon them by the constitutional rígime. 
gradually weakened this superiority and greatly diminished the intellectual force of the dominant class. As Dr. Jacoby has so judiciously remarked: "Men appear to be constituted for equality. All distinctions into political. economic or intellectual classes, and every kind of selection logically resulting from these distinctions, are equally injurious to humanity among the elect as among the rest of mankind. Nature appears to desire to take her revenge upon this violation of her laws and visits her punishments upon the elect even to the seventh generation. Each privilege that man assumes is one step toward degeneration, phrenopathia, and the dying out ot his race." I It will not be necessary to offer detailed proof of this shocking degeneration. We have only to observe with an impartial eye the sad spectacle of unregulated individual interests and passions taking the place of political experience and the art of government in modern civilised countries. But while the capitalist class is pursuing its downward course, the working classes, tempered by hard labour and bitter struggles, are gaining every day in intellectual and moral capacity, and acquiring in constantly increasing measure the qualities that will ultimately fit them to rule. Thus at the moment when the economic basis is being disturbed upon which the political authority of the bourgeoisie has so long reposed, we see also the gradual disappearance of the conditions of intellectual superiority which originally justified their dictatorship. Hence the necessity of wresting political authority from a plutocracy which is sinking into senile atrophy. Bourgeois hands are no longer able to wield political power, and it must therefore be committed to the younger and more vigorous representatives now called upon to lead the human race to a higher destiny.

I Jacoby, Études sur la sélection, etc., Paris, 1881, p. 608. 


\section{CHAPTER V.}

\section{PROPERTY AND POLITICS.}

IT only remains for us to draw some of the more important conclusions flowing from these considerations.

Political science has herctofore been dominated by the idea that laws spring full born from the mind of the inspired legislator-prolem sine matre crentam-and that their function is to regulate social relations according to immutable principles of justice. This concept gave jurisprudence its former prestige, and made public law the foundation and keystone of social science. This was particularly true of the last century, but with a deeper insight into the composition of society a new concept has since ariscn, and the law is now coming to be regarded as an organic product of economic conditions, rather than the chance result of the legislator's will. Thus the carlier superficial idea of the relations cxisting hetween legislation and economics is gradually giving place to the decper concept which regards the political constitution as the neccssary outgrowth of the existing cconomic system. The process by which the economic system thus determines its corresponding political constitution, the organic hond which unites the one to the other, is the political monopoly of property. By its means economic conditions determine the composition of the State, and direct legislation in the way best calculated to serve the interests of the exploiters of the economic system, and consolidate their power. Thus politics is but a method of survival, and a means of preserving and extending the property system.' The older concept, which regurded law as the

1 A propos of this, Colinjanni remarks that in German the word Reich means rich and cmpre (Soculogua Criminale, vol. ii., p. 593). One might add that in English also the word Commonwealth is often used for Kefublic. 
determinant of economic relations, made jurisprudence the social science par excellence; but the more modern concept that takes economic conditions as the basis of politics and legislation canonises political economy (whose very name it justifies), and makes it the foundation of all the social sciences.

We should hasten to remark that this theory does not go so far as to maintain that economic conditions may not be modified by law. It is a great mistake to suppose that the theory which makes legislation depend upon economic conditions can he successfully combated by showing that these relations can themselves be effectively modified by law. The economic concept of the State is in no wise disturbed by such considerations, as it rests upon the truth of this proposition. If legislation were really powerless to modify economic conditions, and if the immediate economic situation were irrevocably determined by natural law, there would then be no reason for the proprietors to possess themselves of political authority; for in this case, even though the non-proprietors possessed legislative functions, they would still find it impossible to effect any modification in the existing social order. If then the concept of economic law, as conceived by orthodox science, were in conformity with the true state of things, the capitalistic composition of the State would no longer have any logical justification, and the political constitution would cease to have any connection with the economic system. It is thus only by admitting that legislation is capable of modifying social conditions that we arrive at the conclusion that, in the interest of their own preservation, the proprietary classes must possess themselves of political power in order to direct legislation in accordance with the property system. Our immediate deduction must then be that the law is only capable of modifying economic relations in so far as economic conditions are able to modify themselves. If, in' short, the economic system determines the political constitution, and the latter in turn may by legislative action alter its economic base, it is evident that the law simply acts as an intermediary, through whose instrumentality the economic system succeeds in modifying itself, 
and that, as a matter of fact, economic relations develop and change by a natural process of intrinsic elaboration.

Another conclusion may be drawn from this theory of the economic basis of politics: it alone succeeds in pronouncing a decisive sentence upon the theory which represents the State as the product of a social contract. If we limit our researches to the primitive epoch when property was still collective, it is impossible to deny the rationality of this theory. 1t might, indeed, be accepted, unless facts showed that the State was a spontaneous product of economic conditions. But the moment we reach the period of private property, the theory becomes irrational and absurd. Under such conditions what, indeed, would the social contract mean? It would simply be an act by which those excluded from property, or, in other words, the great mass of the people, voluntarily renounced the exercise of their individual will, in order to submit themselves, not to a general will in which they were to participate, but to the controlling will of the proprietary class. Now how can we possibly suppose the disinherited would ever consent to so one-sided a contract? And even supposing an unconsidered consent, would they not soon see the error of their choicc and return to the state of nature? To suppose the contrary it would evidently be necessary to eliminate the element of personal interest which amounts to a denial of one of the most elementary principles of human nature. ${ }^{1}$

'Though inclined to be paradoxical, linguet still recognised this contradiction in the theory that founds the State on a contract. He made the following judicious observation: "Cette union, qui légitime une propricté exclusive, cette confédération qui ne s'étend quau petit nombre et dont le but est d'ćterniser l'asservissement de la multitude, est-elle naturelle? A-t-clle pu jamais etre volontaire? Elle a dì léser, dès le commencement, les intérêts de quelqu'un, puisqu'elle prononçait unc exclusion. Dis qu'clle donmait aux uns, elle restreignat les prétentions des autres. Elle n'a done élé formie qu'entre ceux qui participaient à ses avantages. Pour anener le reste des hommes dy accéder, il a fallu les y contraindre" (Théurie des lois ciziles, 1797, i., pp. 310-11). Linguet is, however, wrong in supposing that, if we exclude the hypothesis of the social contract, civil socicty could only have originated in violence; for if violenee is able to destroy a social system it cannot, at the same time, succed in substituting a new and more 
It is just this inherent contradiction between the economic constitution of the State and the logical possibility of the social contract that caused the best theorists of this system to fall in to the most hopeless confusion. Thus, Hobbes, who eulogised the social State so enthusiastically and contrasted its advantages with the horrors of the State of nature, found himself inevitably led to endow his State, the Leviathan, with tyrannical power over its members, and proclaim the excellence of absolute government. But if society be advantageous to its members, what is the necessity of an absolute sovereign to compel them to remain in the association? We only escape from the dilemma when we look upon the State as an instrument of the proprietary class. From this point of view we can readily perceive that those excluded from property are naturally inclined to rebel against the exactions of the dominant class, and that they must, consequently, be held in check by a yoke of iron and led by an inexorable master. But this solution does not yet put an end to all the contradictions involved; for if the State is the result of a contract, it is dissoluble any moment at the will of one of the contracting parties; and no absolute power could therefore prevent the more numerous classes of society from brealking the civil association. Hence, in spite of the absolutism of the sovereign, the dissolution of the State would be inevitable. And again, if an absolute sovereign be necessary to hold the subjugated classes in obedience, how has it been possible to establish the Liberal Governments of the day?

Such are some of the contradictions in Hobbes' theory. Rousseau, coming after, agreed with his English predecessor that the State had its origin in a contract; but instead of concluding in favour of absolute government, Rousseau proclaimed himself the prophet of political liberty. But Rousseau's conclusions are equally contradictory; for while granting the

stable form ; and besides, violenee could never succeed in stubjecting the whole mass of the nation for all time to the few. It is only when we come to regard the political constitution as the product of economic necessity that we are able to understand how the classes excluded from revenue and power subsist in the civil association. 
economic composition of the State, and admitting property's political monopoly, he still believed the non-owning classes would respect a contract which turned to their own disadvantage. "Laws," he says, "are always useful to those who own, and injurious to those who do not own. It follows from this that the social State is advantageous to men in so far as all possess something, and no one of them owns too much." 1 But once we admit the plutocratic character of the State, it is difficult to understand why the disinherited should voluntarily submit to a system which they could at any instant destroy by abrogating the original contract. Rousseau only succeeds in avoiding this contradiction by a trivial subterfuge. He imagines that when the natural development of society gave rise to private property, the proprietors set a silly trap for those excluded from ownership, persuading them with fallacious arguments to put an end to their struggles with the rich, and join with them in establishing a civil society that would eventually redound to the exclusive advantage of the proprictors thenselves. $^{2}$ But even supposing the proletarians of primitive times to have been stupid enough to be persuaded by a proposition of this kind, their descendants, somewhat further removed from the state of nature, must certainly have had their intelligence sufficiently developed to comprehend the enormity of so one-sided a contract. Thus admitting the economic basis of the general will, the necessary deduction from the social contract theory would be the total irrationality of the State and the logical necessity of its immediate destruction. ${ }^{3}$ IVe can only escape this conclusion by regarding the State as a natural product of economic conditions. We must recognise, in other words, that the labourer's acquiescence in the resime of civil society is not the result of any free choice on his part, hut the effect of his condition of servitude, hrought about by the suppression of the free land, which compels him to endure the zconomic and political domination of the proprietors, and

${ }^{1}$ Contrat Social, bk, i., ch, ix.

2 Rousseau, De l'inégalité des conditions, ii.

s See on this subject Hume's profuund observations in his Essays, pp. $281-83$. 
obey the laws they establish. The State has not its raison d'être in the will of its citizens, nor has any one class, however large, sufficient power to destroy it; for it rests upon the granite foundations of natural necessity, and continues to exist however violent the opposition of those excluded from political government.

It is a singularly characteristic fact that these palpable truths, ignored by modern economists, were very well recognised by past century writers. As early as 1656,1 James Harrington, for the first time propounded the theory that the political constitution is the product of economic conditions. "Dominion is property," he wrote in his Oceana, "as is the proportion or balance of Dominion or Property in Land, such is the nature of the Empire. If one Man be the sole Landlord of a Territory, or overbalance the People, . . . he is Grand Signior. . . . If the Few or a Nobility with the Clergy be Landlords or overbalance the People,... the Empire is mix'd Monarchy, And if the whole People be Landlords, ... the Empire is a Commonwealth." 2 The conditions of the age explain why Harrington limited his considerations to landed property, and

${ }^{1}$ A repeated study of the Oceana makes it impossible for me to agree with Cossa (see his excellent Introduzione allo studio della Economia Politica, Milan, 1892, p. 182) that this work had already been published in 1640. I am led to believe that the real date of its publication was 1656 . To persuade oneself of this, it is sufficient to note that the work is dedicated To His Highncss the Lord Protector of the Commonwealth of England, Scotland and Ircland, and that Cromwell figures in the course of the book under the name of Olphaus Megaletor, Lord Archon and Sole Legislator of Oceana. Now we know that Cromwell was not proclaimed Protector until the month of December, 1653. The well-known anecdote concerning Harrington and Lady Claypole, Cromwell's daughter, relative to the manuscript of Oceana, proves equally well that the book was not yet published when Cromwell became Protector (Guizot, République d'Angleterre, 1864, ii., p. 165). Moreover, even though Toland does not indicate the precise date of the publication, the date 1656 seems to me to be confirmed from the fact recounted by Toland himself, that upon its publication the work was violently criticised by a certain Dr. Henry Ferne, and that Harrington replied immediately in 1656.

${ }^{2}$ Harrington, The Oceana and-other Works, collected, etc., by Toland, Ed., London, 1700, pp. 39-40. 
in another essay he said: "Property in Mony (except, as has bin shewn, in Citys that have little or no Territory), coms not to the present account. But Property in Land, according to the distribution that happens to be of the same, causes the political Balance-producing Empire of the like nature.... So an Agrarian is a Law fixing the Balance of a Government in such a manner that it cannot alter." 1 Toland in his life of Harrington says Harrington was the first to discover that "Empire follows the Balance of Property," and this discovery he likens to those of the circulation of the blood, of printing, of guns, etc. "'Tis incredible to thinls," he adds, "what gross and numberless Errors were committed by all the Writers before him, even by the best of them, for want of understanding this plain Truth, which is the foundation of all Politics".2

'Harrington, The Prerogative of Popular Government, pp. 290-91.

2 Ibid., p. xvidi. Harrington, it is true, attributed the discovery of this theory to Aristotle, on the ground, perhaps, that he devoted the first two books of his Politics to a study of conomic conditions. But it does not seem to me that we can in any way accept this opinion. To show that Aristotlc was actuated by a directly opposite concept, it is sufficient to recall his idea that when the poor are very numerous in a country, it is they who become the arbiters of public opinion: "Where the number of the poor is more than proportioned to the wealth of the rich, there will naturally be a democracy" (Politics, iv., 1296, C. 20). Now it is perfectly evident that there could be no thought more incompatible with the theory of the plutocratic basis of the State. In several other passages, it is true, Aristotle secms to inclinc toward this doctrine. He affirms, indeed, that it is just that those who possess more should also have a larger share in the administration of public affairs: "It would not be just that he who paid one mina should have the same share of a hundied mina as he who pail the remaining ninety-nine" (iii., 1280, A. 30). And elsewhere, he declares still more explicitly that power belongs to the rich: "Besides, the "uling class should be the owners of property, for they are citizens, and the citizens of a State should be in good circum. stances; whereas, mechanics or any other elass whose art excludes the art of virtue have no share in the State" (vii., 1329, A.). But this idea is always expressed in partial declarations, and nowhere appears as a complete and coherent theory. It is, besides, calsy to understand that so long as slavery perailed it was impossible to discover the economic basis of politics. The slave economy suppressed the producer, as the slave was not considered a person. To social science he was a mere abstraction. The slaves being thus excluded from civil government, and 
Harrington's theory met with opposition and scorn at first, but toward the close of the seventeenth century it found an ardent defender in Davenant. Those who possess money, this author wrote, have at all times and in all countries dictated the laws, and subjected the majority of the people to their power. This idea of the dependence of political relations upon economic conditions is also to be met with sporadically in the writers of the eighteenth century, though most of them persisted in the delusion that economic relations were the result of political conditions. Nevertheless, Montesquieu, the most authorised representative of this idea, affirmed that, "les fortunes excessives regardent comme une injure tout ce qu'on ne leur accorde pas de richesse et d'honneur". "Suppose," said an anonymous English author writing in 1756 , "an island inhabited by 10,000 people, and the property of this island to be divided among 1000 , the result would be an aristocratic government." And according to Dalrymple, there is no maxim of politics more generally applicable than that power follows property. "In-

their legal existence ignored, society was made up of freemen who all took part in political sovereignty. Hence it never occurred to the minds of the philosophers that the citizens possessed political power as proprietors of slaves or as unproductive labourers guaranteeing the revenues, but only as freemen, and by a law of naturc. Thus the only task that remained for politics was to so arrange matters that this natural right of freemen should have the largest possible opportunity to develop. It is on this account that Aristotle concerns himself so constantly in his Politics with the struggles between the different classes of freemen, between the optimates and the plebs; but we find no trace of the idea that these two classes, struggling for supremacy, owe their right of ispiring to authority to economic conditions. The instances of the infiuence of economic conditions upon political relations mentioned in Aristotle always concern the relations existing between the different classes of proprietors. "The qualification may have been originally fixcd according to the circumstances of the time in such a manner as to include in an oligarchy a few only, or in a constitutional government the micldle class. But after a time of prosperity, whether arising from peace or some other good fortune, the same property becomes many times as large, and then evcrybody participates in every office; this happens sometimes gradually and insensibly, and sometimes quickly. These are the causes of changes and revolutions in oligarchies" (Politics, v., 1306, C). 
dustry," Sir James Steuart added, "gives wealth, and wealth gives power." Among all the defenders of this thesis, one of the most enthusiastic, if not the most intelligent, was the Prussian minister Herzberg; but influenced by mercantile prejudices, he confounded property relations with the balance of trade. "The balance of trade," said he, "has a real influence on the balance of power; the nations which are commercially strong are politically powerful." And one of the founders of the American Union, John Adams, remarked that those who possess the land, hold the destinies of nations in their hands. ${ }^{1}$

The physiocrats recosnised the economic structure of society, and advocated a State composed exclusively of landed proprietors and ruled in their interests. By attributing political sovereignty to the proprietors of the soil, the physiocratic theory attempted to forestall any attempt on their part to acquire privileges detrimental to the community; for the physiocrats succeeded in proving, and logically enough from their point of view, that it was in the interest of the land owners to bear the entire burden of taxation, because they would be the first to be injured by anything that disturhed national prosperity. Finally the economic structure of the State was also recognised by Adam Smith, who was, indeed, the first econonist to estimate poitical action by taking into account the peculiar economic interests of the different classes composing the State. The great Scotsman's Liberalism was thus much less a product of

'Davenant, II'orks, ed. by Wentworth, London, 1771, i., p. 155. Montesquieu, Esprit des lois, v., 5. Locke, On Cizil Gozernment, ch. v. Anonymous, Enquiry into the Nature, Foundation and Present State of Fl.blic Credit, by a Friend of Trate and Lib.rl!, london, 1756, pr. 7.8. Steuart, loc. cit., i., p. 332 . Herzberg, "Mémoire sur le vrai caractère d'une bonne histoire," in the Memoires de l'Acatimic de Berlin, 1786.

2 "L:Étut ne réside essentiellement que dans le somirirain qui en ist le chef, dins les fropriétaires du produit net, at dans les cutrefreniors de culture" (Nercier de la R.viere, Ordic naturel at essintiel des societicis politiques, edition, Daire, 551). The Abbé Bandeau aftirmed the same (In Production a la philosophic iconomique, ib., 690). But the most ardent upholder of this theory was Germain Garnicr, who in his work, be la propriele daws ses rupports azee le droit folitique, Paris, 1792, maintained the principle that political sovercignty was a nalural altribule of landed property, and should, therefore, be exereised collectively by all proprietors of the soil. 
eighteenth century philosophy than the result of his profound idea that political preponderance naturally belonged to the economically dominant classes. Thanks to this idea, Smith has given us a theory of the State which is inductively correct. He never allowed himself to conceive of an imaginary State ever ready to submit to any changes the theorist might have in mind, but always induced State action and its proper limits from the complex of social relations. After Adam Smith came Arthur Young, who also recognised the organic structure of the State, and expressed himself as follows: "The great line of division, into which the people divides, is first, those that have property, and second, others that have none. . . It is not that the proprietors of property should have voices in the election proportioned to their property, but that men who have a direct interest in the plunder or division of property should be kept at a distance from power. Here lies the great difficulty of modern legislation, to secure property and at the same time to secure freedom to those that have no property." Burke upheld the same ideas when, referring to the first and third assemblies of revolutionary France, he remarked that the government was no longer in the hands of the proprietors; and destruction of property was therefore inevitable. Fox also saw that political power was based upon property. Gentz even took the trouble to calculate the amount of income going to the members of the French assemblies of 1791 and 1792, and found that it did not exceed 100,000 francs Herein, said this author, lay the real cause of the revolutionary tendency of French legislation at this period. These considerations show a deep insight into the organic structure of the State. Later on, Haller, although a defender of the divine right of kings, affirmed that landed property was the basis of power. "A man," said he, "does not possess a demesne because he is a prince, but he is a prince because he possesses a demesne." Thünen also regarded it as one of the greatest contradictions of the parliamentary system that legislative power belonged to the bourgeois class, which exploited the existing economic system and would therefore never consent to have it destroyed. Almost at the same time an eminent American statesman, 
Daniel Webster, wrote: "A republican form of government rests not more on political constitutions than on those laws which regulate the descent and transmission of property. Governments like ours could not have been maintained where property was holden according to the principles of the feudal system. The frecst government, if it could exist, would not be long acceptable if the tendency of the laws were to create a rapid accumulation of property in few hands, and render the great mass of the population dependent and penniless." This idea of the economic basis of politics is to be met with again, though expressed with some hesitation, in Marlo's works; and we find the same theory set forth very freely by Jones, Proudhon, Marx (who throws much light on the question), Engels, Lassalle, Scheel, De Molinari, Gumplowicz and De Greef." "There is neither law nor party," a recent distinguished writer concludes, "which can prevent the economically dominant class from obtaining political power." 2

But this truth so energetically defended by past writers, and still maintained by some few modern representatives, has been completely neglected by the great majority of our best modern

'See Adam Smith, bk. iv., ch. vii.; lsk. i., ch., x., part ii.; bk. i., ch. xi., part iii., etc. A. Young, loc. cit., i., p. 615. Burlic, Reflections on the Revolution in France. Haller, Resturation der Stantswissenschaften, Winterthur, 1816-18, ji., p. 268. Jones, Literary Komains, London, 1859, pp. 234-36. Thümen, Der Isolirte Staat, Berlin, 1875, ij., p. 40. Webster, Works, i., pp. 35-38. Proudlion, Qu'estce que latrofricte, Denxiome Mimoire (Ocuvrcs, 1'aris, 1873, i., p. 278 ff.). Marx, Zur Kritik der politischen Oekonomie, Berlin, 1859, preface, v.-vi., and Dets Kapital, p. 122 and passim. De Molinari, loc. cit., p. $313 \mathrm{ff}$. Gumplowicz, (irmultiss der Sociologie, Vienna, 1885 , p. 116 and passin. De Greef, loc. cit., i., p. 165 ff.; ii., p. $21 \mathrm{ff}$. Marlo, loc. cit., i., p. $400 \mathrm{ff}$. Scheel, Theric der sozialen Frage, Jena, 1871. Mazzini himself, although inclined like all writers of our heroic age to exaggerate the influence of political relitions upon economic conditions, admits the economic composition of the state, and declares that society is regulated exclusively by the hoiders of fincis and the owners of capial (Prose politiche, Flunence, 1848, p. 151.)

${ }^{2} \mathrm{Dr}$. Dietzel in his interesting work on the Relation hitaten Politica? Economy and the Social Scionces, Berlin, 1S81, pp. 40.41. Schaefile also (Kapitalismus und Socialismus, 1878) regards the Socialisls of the Chair iti error when they suppose the modern liberal State can effect any great changes in the existing economic system. 
economists. Under the impulse of philanthropic sentiments these theorists are really establishing under deceptive appearances the old sophism of the dependence of economic conditions upon the law, ${ }^{1}$ and proclaiming the doctrine that the State can change its economic base on scientific principles, even though such changes involve an important limitation or actual violation of the property system. This idea, which was received with such great favour in Germany, is now passing over into Italy, by virtue of a singular process of doctrinal transm:gration of which we ltalians have several times felt the evil effects.

${ }^{1}$ The illusion that represents law as a product of the will of the sovereign exercises its injurious influence upon questions that are apparently far removed from those we are considering. Thus, one of the most distinguished representatives of the Socialists of the. Chair in Italy believes that the statistics cannot deal with political facts because they depend upon the will of the Government and cannot, therefore, present the normal conditions necessary to statistical investigation (Ferraris, Saggi di Economia, Statistica e Scienza dcll' Amministrazione, Turin, 1880, p. 82). The observation holds good, as we can see, for all who belicve the State to be guided by its own will and to rule with its own force; but it falls to the ground before the theory that regards the acts of collective authority as the necessary results of economic conditions, and accordingly of a sufficient degree of social regularity for statistical obscrvation.

To our objections, Ferraris replies, that, while affirming the dependence of political institutions upon the law, he docs not mean to declare that they are the arbitrary products of government; he regards them, on the contrary, as the necessary result of historical causes (La statistica lc sue partizioni ecc, Venice, 1890, p. 9). True, but if the law be but the formal expression of necessary historical causes, there is no longer any rcason to exclude political facts from statistical research. The mere assertion that facts arc produced because there is a law that induces them, carries no weight against this conclusion, inasmuch as the law itself only exists by virtue of social causes that render it active. Those who take Ferraris' view of the matter should recognise that the dependence of political facts upon the law only represents the first phase, or the mere surface, of the phenomenon. At bottom we shall find that these facts-like all social phenomena-really depend upon an cnsemblc of causes that are perfectly susceptible of statistical research. De Gabaglio's observations upon this point appear to us to be excellent (Tcoria gencrale della statistica, 2nd ed., Milan, 1888). 
Legend tells us of an Anglo-Saxon warrior who found, on his return from a campaign in a far-off land, that a son had been born to his wife. When he showed his bitter resentment and reproached his spouse for her infidelity, she replied that the child was not born in $\sin$ but was the offspring of a wonderful miracle; that one winter day as she was walking in the country a flake of snow descended upon her and she became a mother. For this reason the boy was called the "snow-child" by the people. The husband affected to believe the prodigy, and as he was about to depart on another campaign in Italy he desired the child should accompany him. But scarcely was he departed from his country when he put the boy to death. On returning alone to England the disconsolate mother asked him what had become of her child. "He was the child of the snow," the husband replied, "and when he approached the land of the sun he melted away."

This old legend may be taken as an allegory in the history of social science. At every phase in the development of this science, northern theories, children of the snow and born of an illegitimate union of sophisms and utopias, have descended triumphantly into Italy, suddenly to become liquefied there under the burning rays of southern logic. Thus the doctrine of the "ethical principle," so long held in respect by German economists, after a brief vogue in Italy, died out and was soon forgotten. The exaggerations of a few inductive writers of the North, who desired to convert the science into an everyday recital of facts and a series of little histories more or less recreative in character, found but fleeting response in Italy and were soon reduced to desuetude. The socialist theory of value, which met with no decisive refutation in the country where it was born, was reduced to a palpable absurdity by Italian writers. The sterile metaphysical disquisitions on the theory of utility which for a brief space intoxicated the Italians, were soon either abandoned or refuted. Thus if Italy cannot yet take pride in having given a new turn to social science, she can at least flatter herself that she has stripped sophism of its faded laurels, and hastened the triumph of truth by destroying false doctrines. 
As one of the most intelligent of Italian writers $^{1}$ has expressed it: During these memorable times when we were celebrating with prans of enthusiasm the advent into Italy of the "ethical principle," a celebrated theory, which had long been evolving in the favourable atmosphere of Germany, came to us in the triumphal train of this idea. This was the doctrine of State Socialism, which demanded instant recognition from the Latin races. Indeed, of all the theories that have in recent times disputed the field of social science, there is none which carries a more marked impress of German genius than this, and none whose Teutonic filiation is more direct. $1 \mathrm{t}$ is, indeed, a strange thing that the same German genius, which, in the early stages of its history was inspired by the spirit of absolute individualism, should in its maturity give birth to this concept of State omnipotence, which is now making its infiuence felt upon the entire intellectual life of the nation. Long before economists began to make their practical applications of the theory, the idea had already found immortal expression in the works of the philosophers, the jurists and the poets. of Germany. Goethe's poem, which contrasts the supreme truth and omnipotence of government with the vanities of science and love, is, indeed, a fitting counterpart to the Hegelian philosophy which celebrates the deification of collective authority. It is true, this faith found its support in the prevailing conditions of the epoch; for Napoleon was then transcending all bounds the mind had formerly set to political power, and proclaiming his belief that, in modern society, Politics was to take the place of the Destiny of the Greelss, and determine the fate of humanity. But even during the subsequent period, when mean administrative cunning, and the somnolent government of a host of petty princes succeeded the rule of political genius, the belief in the omnipotence of the State still persisted in Germany. Indeed, the faith continued to grow until the economists finally made use of the theory to establish the dogma that the State could and should undertake to modify the social order, and that it was only by the application of 
collective authority that the iniquities disgracing modern society could ever be done away with.

The doctrine was hailed with enthusiasm by writers who preferred to dispense with profound research into economic conditions and their development. If, indeed, economic relations are capable of modification by State action, all serious study of economics is without purpose, and, in the end, impossible. Without purpose, because a bare examination of the injuries resulting from existing institutions is sufficient to advise a change, and indicate the character of the new system. Impossible, because social relations which may be altered by a decree of government, cannot be deep-rooted in history and human nature, and thus only to be explained as results of the individual or collective proclivities of a preceding period. We find all the scientific productions inspired by this theory regularly divided into two parts: in the first, the author weeps literary tears over the injuries flowing from a certain institution, while in the second, he involses State aid to repair the deplorable defects. In place of the confessedly objective mathematical studies undertaken by those who believe economic conditions incapable of modification by human hands, and only alterable by natural processes, we have eloquent declamations, detailed descriptions of the social evil, and suggestions of remedia! measures. Instead of remaining an analysis of human society, a social physics, political economy thus becomes a mere science of administration, a vade mecum for officials; and the moment politics enters the domain of economics, its scientific character disappears.

If, however, the theory of State omnipotence could only be criticised from the standpoint of its destructive influence upon cconomic science, no decisive refutation of the doctrine woukl he possible; for it could always he rejoined that, far from being a weakness, this dethronement of economic science constitutes the chief glory of the new doctrine, whose purpose it is to demonstrate the futility of profound rescarch into such subjects. It is not enough, therefore, merely to determine the influence of the new doctrine upon the older science. It is necessary to ascertain the scientific value of State socialism itself, and 
decide whether this new dogma of political economy will stand the tests of logic. But here a further remark is necessary. The endless struggle between the defenders of constituted authority and the advocates of economic liberalism has recently resolved itself into a discussion over the proper limits of individual enterprise, and the justice or opportuneness of an extension of collective initiative. This is the theme which, in our day, Herbert Spencer, Émile de Laveleye and Minghetti have disputed with an eloquence worthy of their high intelligence. ${ }^{1}$ But in our opinion this is not the ground upon which the question should be discussed. If, however, called upon to express a personal opinion on this subject (which seems to lend itself more to a personal estinate of the leaders of the different schools than to real scientific research), we should not hesitate to range ourselves with those who recognise the right of energetic State action to modify social conditions. In fact we cannot see that the most jealous defender of individual liberty, or the greatest enemy of tyranny, has any more right to regard vigorous State action in defence of the poor classes, as the prelude to a coming era of slavery, than the premonition of a period of human redemption, when the liberty of the whole human race will be substituted for the privilege of the chosen few. But we are forced to add that disquisitions of this character, touching the justice and opportuneness of State interference, must always remain barren of result, because the limits of collective action are not marked out by abstract principles of morality and justice, but determined exclusively by the organic structure of the State itself. One might perfectly well recognise, for example, the justice of State intervention for the abolition of slavery; but a State composed of slave owners would never proclaim the freedom of labour until economic conditions rendered such a step advantageous to them. Inquiries into abstract justice can, therefore, never determine whether State action is able to relieve humanity of

'See Spencer, Man v. the State, London, 1885. Émile de Laveleye and Spencer, L'Etat et l'Individu ou Darvinisme Social et Christianisme, Florence, 1885. Ninghetti, "Il Cittadino e lo Stato" in the Nuova Antologia, November, 1885. 
the ills that assail it. We have first to seek a solution of the more modest and positive problem, whether, given the actual constitution of the State, collective action for the purpose of substantially modifying the social system is practically possible. The organic composition of the State is the unknown quantity which alone affords us the key to the solution of the proposed problem. This, then, is the question upon which we must rivet our entire attention.

The careful study we have made of this problem in the preceding pages justifies our present conclusion, that the confidence modern writers accord State action proceeds from an insufficient knowledge of the organic structure of society. These present day economists, who magnify the economic dignity of the State, draw their demonstrations solely from the principles of legal philosophy. Imbued with the profound doctrines of Hegel, Ahrens and Romagnosi, they conclude that the State has the right to intervene for the purpose of modifying the natural economic system and changing its base. But these writers fail to take into consideration a very simple fact, which should check their immoderate enthusiasm. False to the experimental method in which they clain to believe, they never ask thenselves whether the State is actually capable of introducing organic changes into the economic system. The socialists never face this problem; in fact, they cannot face it as long as they continue to regard the State as something entirely above society, ruling over humanity like some superior divinity. Nevertheless, if we rellect for an instant upon the actual composition of the State, we shall perceive at once that, being, as Minghetti himself admits, an organ of socicty, the State must draw its form and content from the particular social organism whence it emanates. The State is, in other words, the political expression of the existing economic system, and is always composed, therefore, of the cconomically dominant class. This being estahlished, it is difficult to conceive how such eminent thinkers could possibly uphold so scrious a petitio principii as this: that the State is capable of profoundly modifying existing economic conditions. If, as these conomists affirm, the capitalists as a body are ruled by the criteria of 
personal interest, how can we suppose they will suddenly abandon this standard on the threshold of their parliamentary assemblies and proceed to effect their own economic suicide? But if, on the contrary, the capitalists are governed by altruistic standards, and are disposed in their legislative capacity to favour measures leading to their own negation as a class, why do they not proceed directly to this end, and openly renounce their economic predominance, instead of acting stupidly in two opposite senses, employing their economic power to destroy itself. If, on the one hand, the capitalist class is dominated by personal interest, governmental modification of the existing economic system is an absurdity. If, on the other hand, the class is governed by altruistic criteria, governmental authority to modify the economic system is superfiuous, since, in this case, the same influences that direct the capitalists in their economic conduct would of themselves suffice to assure the most perfect system of social justice. In either case, State intervention to regenerate the economic system is irrational. Thus if we suppose the State, as at present constituted, to work toward an effectual amelioration in the lot of the working class, we are justifying a political error, nothing more. ${ }^{1}$

In affirming the inherent impossibility of a radical change being effected in economic conditions through collective intervention, we do not wish to deny the possibility of State action palliating the evils resulting from such conditions, for interference of this kind is perfectly feasible so long as it does not modify the essential rights of the dominant class. The fact that political sovereignty is derived from economic revenue does not, for example, preclude the possibility of ameliorating the hygienic surroundings of the labouring class. Legislation of this kind in no way alters the condition of the capitalists, for it neither affects the stability of the wage system nor threatens the existence of rent and profits. On the contrary, such ameliorations are actually advantageous to property in that they increase the vitality of human labour, the only real

${ }^{1}$ Loria, La rendita fondiaria e la sua elisione naturale, Milan, 1880, p. 193. See also La legge di popolazione ed il sistema sociale, Sienna, 1882, p. 50. 
source of income. In short, the social legislation of the day really contains nothing contradictory to the capitalistic structure of the State, and the proposals made by modern economists (with Luzzatti at their head in Italy) to ameliorate the condition of the poorer classes, are bound to be fruitful so long as they confine themselves within the above-mentioned limits. But when the economist proposes State intervention to alter existing economic conditions, either by the confiscation of landed property, or by a progressive tax leading to the sequestration of fortunes, or by establishing communistic enterprises (as Wagner proposes in Germany), he forgets the organic composition of the State, and fails to perceive that the economic forces he is aiming to destroy are the mainstay of the political constitution. His rôle is honourable enough, but his usefulness is that of the rox clamantis in deserto.

But our assertion will probably be objected to on the ground that, given the inherent inability of the State to alter its economic base, science must either stir up a revolution or resign itself with oriental fatalism to the development of economic conditions. This would break all existing bonds between science and the art of government, it would do away with the legislative function entirely, and destroy the power of the intellect to enlighten and direct mankind in the battles of life. Science would thus become either impotent or revolutionary.

It appears to us, however, that those who grant the inherent inability of the State to modify the economic system, and conclude from this that salvation can only be secured by a violent revolution, are unconsciously influenced by the old idca of the fixity of economic resations. Of course, if we refuse to admit that social conditions are subject to a continual ferment, which itself produces constant metamorphoses, we can only expect such transformations to be effected by the aets of man. If such actions were regulated and disciplined, we should describe it as reform, but if unorganised and anarchic, we should call it revolution. On these premisses it is also heyond question that the inability of the State to effect such radical reforms allows no other alternative in the declining stage of society than revolution. But this is one of those ancient dogmas which modern 
science must destroy The belief is, indeed, unconsciously pervading the scientific mind that, in the social as well as in the physical world, every structure is subjected to the transforming process of organic evolution. Economic conditions are, in short, subjected to a process of transformation, and pass, as we have seen, from one form to another by virtue of an inherent force and in spite of all human opposition.

If this be true, the dogma of State socialism is irreconcilable with the evolutional process. If, on the other hand, we accept the economic theory of the State, we are able to apply the law of evolution to social phenomena. Were the State in a position to modify its economic base according to its own enlightened or despotic will, there would no longer be any bond of connection in human events and nothing to determine their course-the free will of man would replace the unconscious trend of history. But if, on the contrary, we recognise the economic basis of political power, there is no longer any illusion concerning the latter's ability to alter its economic base, and we are forced to conclude that a modification of economic rclations can only be derived from economic conditions themselves. It is the progression of social facts that sets in motion the force required to destroy the existing economic form and replace it by a new and more complex system. The rising social form thus destroys its progenitor-parricide is the law of history.

By this fundamental doctrine modern science removes the necessity of violent revolution, and demonstrates the absurdity of such a process by showing the utter inability of popular revolt to modify an historically necessary social system. An analysis of the capitalistic economy teaches us that no revolution can be really general and effective until unproductive labour detaches itself from its normal alliance with the revenues to join forces with productive labour and set forth its claims. It shows us also that this, alliance between the unproductive labourers and the disinherited of the earth can only be effected when the progressive diminution of the revenues has converted the unproductive labourers into opponents of the existing property system. A successful revolution can only occur, 
therefore, when the normal development of the existing economic system has reached the point described for its own destruction. In other words, a successful attack can only be directed against an existing social system after the natural forces leading to its destruction have already been set in motion. It follows from this, e contrario, that every revolt attempted by the working classes beiore the critical period has arrived, and while unproductive labour is still allied with capital, must remain abortive. All revolutions undertaken by the non-proprietary classes alone, without the support of the unproductive labourers, are thus foredoomed to failure. The rebels, divided and disorganised, not at all sure of themselves and uncertain of the ends they would attain, soon fall back under the dominion of the proprietary class. Two typical examples may be taken to prove the assertion. The ancient economy was not destroyed by the revolt of the slaves, nor was the ruin of the medireval economy effected by the armed uprising of the serfs. These two economic systems did not succumb until the clients of the Roman economy and the ecclesiastics of the medixval economy were induced by a falling off of their share in the constantly decreasing reventies to break their long standing alliance with the revenue-holders and lend their support to the final revolt of the labouring classes. In other words, these two systems continued to persist until the inevitable progress of economic development rendered them intolerable.

The conviction that the popular classes are powerless to destroy the existing order of things by a violent revolution has already begun to take hold of the minds of both the dominant and disinherited classes. The following facts furnish striking illustration of the truth of this assertion. Under the social systems preceding our modern economy, the dominant class had to take constant care to exclude the subjugated class from military service. Neither the slaves of classic antiquity nor the serfs of the middle ages were allowed to carry arms. During the classic period military service was a privilege belonging exclusively to freemen, and during the middle ages the right to carry arms was a prerogative of the feudal lords 
and, in some cases, of the small proprietors. Afterwards, when paid troops came to talie the place of the feudal militia, each State endeavoured to recruit its mercenary army from foreigners, in order to avoid the dangerous alternative of inuring its national population to war. Some of the more conservative publicists of the last century, Arthur Young among others, were seriously exercised over the dangers to which the property system would be exposed by establishing a national militia. For this reason some thought it better to replace the national army with a bourgeois militia, so that property should be represented in the ranks as well as in the State. ${ }^{1}$ But the bourgeoisie had very different views on the matter, and continued to organise the proletariat on a military basis. Why? because they understood instinctively that though physically capable-by virtue of its numbers and independently of any military organisation-of overturning the property system, the proletariat class would still find itself powerless before the compact alliance effected between unproductive labour and the revenues; for this alliance, while reinforcing the revenues with efficient support, at the same time deprived the labouring classes of all intelligent direction and revolutionary spirit. Once convinced of the absolute powerlessness of the working men to overthrow the capitalist system, all the apparent danger suggested by the military organisation of the lower classes at once disappears; for of what use are arms when their possessors do not know how to use them to their own advantage? On the contrary, military organisation only affords the proprietors another means of holding the needy under their control by establishing a new phalanx of unproductive labourers. Thus the officers of the arny are able to

${ }^{1}$ Arthur Young, loc. cit., ii., pp. 450-51. Merlin, likewise, in his Rapport à l'Asscmblée Nationale du 20 avril 1790, asked whether it were not better to limit the right of carrying arms to citoyens actifs, and in the country to those who possessed a certain amount of landed property (Kareew, loc. cit., p. 412). Hallam also, speaking of the militia established in 1757 in England and commanded by "gentlemen of sufficient estates," added that the militia ought to be established "on its only real basis, that of real property" (Constitutional History of England, iii., p. 349). 
subject a portion of the poor population to the strictest discipline, and so detach them from their fellows that they may be led against the people if the latter perchance revolt.

It is not surprising, therefore, that this military organisation of the poorer classes, that so alarmed the writers at the beginning of the bourgeois age, is to-day a matter of concern to no one. In short, the bourgeoisie, with an equal sense of security, makes use of proletarian soldiers as well as proletarian labourer's. ${ }^{1}$

But some one is sure to answer: your theory leads to a pernicious quietism by excluding the very possibility of human activity remedying economic evil. In the light of the theory of evolution as it is generally understood, the objection cannot he denied; for this doctrine affirms the normality of incessant progress. True, the current theory admits that evolution in general reaches its final stage in dissolution, and it takes pains io demonstrate this fact by an infinite number of examples drawn from the inorganic and the organic world. But when these theorists come to analyse social phenomena, they appear io forget that the process of disintegration forms an integral part of the law of evolution, and we consequently seek in vain for any recognition of the importance of this process in historical development. We might almost say that we are confronted by two theories of social evolution, or that the same theory has two sides. In so far as the theory amounts to a superficial and incomplete application of biological laws to social phenomena, the idea of evolution meets with the approval of the dominant class; first, because it proclaims the impotence of reformers; secondly, because it emphasises the fleeting character of secondary economic phenomena, and fails to take account of underlying economic categories which, for this reason, appear eternal; and finally, because it represents social development as a spontaneous and continued progress

This naturally does not exclude the possibility of a portion of the army sometimes fraternising with the proletariat in revolt. But this is always an exceptional case, a necessarily partial phenomenon, and barren of serious results so long as no alliance is thereby sealed between the unproductive labourers and the people. 
which, without interruption, without upheaval and without violence, leads to universal betterment, and therewith conduces to the profit of both the oppressors and the oppressed. But in so far as it involves a profound investigation of economic conditions from their genesis to their ultimate decay, the theory of evolution meets with the instinctive aversion of the ruling classes; first, because it includes every economic relation and brings them all under its fatal progression; secondly, because it realises the necessity of the existing state of affairs and can yet conceive of the future necessity of their non-existence ; and, finally, because it reveals the fact that the necessary changes are not effected by a gentle insensible process working to every one's advantage, but by a series of catastrophes, revolutions, and general disturbances lasting through an epoch of social atrophy.

If taken in the former of these two senses, the law of evolution leaves no practical task for social science to perform and robs it of all influence upon human progress; but if understood in the latter sense, which is the only correct one, it assigns the science a practical rôle, modest perhaps, but not without an importance of its own. From a profound study of economic conditions, science is, in this sense, called upon to draw its conclusions as to the character of the coning social change and to propose measures to attenuate the catastrophes which must inevitably accompany the approaching transformation. The practical task thus imposed upon economic science stands in no sort of opposition to the exclusive retention of political power by the proprietary classes. Indeed, as soon as the necessity of a social transformation is definitely demonstrated, it is to the interest of these classes to facilitate the inevitable transition as far as possible by mitigating the resulting disturbances which are sure to affect them first of all. With a view to establishing a rational system of social politics within the limits thus defined, science can, consequently, call upon the dominant classes. It need not, however, invoke their philanthropic approval, for' it is enough to appeal to their enlightened self-interest and show them that it is to their direct advantage to undertake to render the necessary social transformation less painful a process. 
Considered in its practical aspect, the task thus assigned is, indeed, limited and modest in character; but it is the only one compatible with the existence of economics as a science. Of course if we were to admit that economics could propose radical social reforms that were in any way realisable, the practical function of the science and its influence on human life would be enormously extended. But we would thereby destroy the science itself by sapping its roots; for we would be denying the existence of the essential conditions, independent of human will, which constitute the necessary basis of all scientific thought. Proof of this lies in the fact that the period during which the world was dominated by a belief in the efficacy of arbitrary reforms was likewise the prehistoric period of social science. Indeed, economics only arose after the concept had come to prevail that social relations possess a consistency of their own and are subjected to an organic process before which the will of man must bend. The limited rôle assigned to social science in practice is, therefore, the condition sine qua non of the continued existence of such a science.

But restricted as it is, this practical function still imposes an inordinate theoretical task upon scientific thought. After what has been said it can readily be seen that economic science can only exert its influence on practical life provided it is able to follow the normal evolution of humanity and predict the coming social system. What then is the nature of the new form that economic relations will assume? This is the great problem of political economy, and in its solution, though apparently hypothetical and conjectural, lies the only hope of economic science being able to propose practical rules for the guidance of social legislation within the limits prescribed. We have elsewhere devoted long and laborious investigation to this great problem, but its solution cannot be definitely reached until all the choicest intellects of the world co-operate to realise this end.

The limits imposed by this essay do not permit us to fix our attention upon the problem of the coming economic system, but one truth, at least, has come to us in passing-and all history confirms it - namely, that the ultimate economic form, while presenting the highest stange of development and the 
nearest approach to perfection, will, at the same time, differ less than any of the preceding systems from the primitive social structure of humanity. This profound identity between the first and the last stages of social evolution corresponds to a logical law which is apparent to all who reflect upon the course of human development. During the first phase of the process all the constituent elements of the social organism are already in existence, but in an embryonic state, which can only be brought to maturity by a long process of historical elaboration. Each successive stage develops one of the organic elements existing in germ in the primitive period, and with the growth of each of these elements the structure of society, and the laws by which it is governed, undergo successive modifications. Thus, after all the elements existing in a germinal state in primitive humanity have attained their complete development, the final structure of society will be but a gigantic reflex of the primitive social organism, because the same elements that coexisted in the primitive organism at a like degree of embryonic development will also coexist in the fina! social organism at a like degree of maximum development. A great writer has affirmed that the human physiognomy attains its greatest beauty at the moment of birth and at the moment of death, because in the former case the destroying influences of life are not yet in operation, and because in the latter case they have disappeared. So, too, the social physiognomy presents its most harmonious and beautiful type at the outset and the end of its secular development, because at the first and last phases of humanity all the elements composing the social organism arrive at the same degree of development, while the intermediate stages of historical evolution are characterised by the preponderant development of some social factors over others which remain in the germ state. Hence the final social system ought to present the greatest quantitative divergence, and, at the same time, the closest qualitative analogy with the primitive social form. ${ }^{1}$ The last' term of history should thus reproduce the first:-

1 If we compare the economic system, based upon the mixed association (which we believe to be the form of the future), with the primitive 
Nil erit ulterius quod nostris moribus addat Posteritas

This tendency of the stream of life to remount to its sources, this circular movement of history, was recognised intuitively by primitive peoples, who represented the course of historical development by a circle. Such was the mysterious Kneph, emblem of the eternal recurrence of things. Such also was the mystical tradition of the religrious epopee, which tells us of a primitive age of unconscious brute happiness whence man was cast forth into a world of $\sin$ and passion, from which he will one day emerge (the sacred books predict) and return, purificl and redecmed, to the blessed peace of the early age. Such, finally, is the touching legend of Nazeppa, the marvellous and picturcsque symbol of the course of human events. Mazeppa was young, happy and ardent, but a harsh sentence stopped him in his joyous career, and stretched him bound on the back of an untamed steed, that bore him bounding and rearing across desolate steppes, until the miserable rider, bloodstained and tortured with pain from his awful course, found an asylum at last with the devout virgin of the Ukraine. There he received a royal crown, and attained grandeur and glory in his new-found country.

Such is the history of the human race. Out of the brute felicity of primitive communism mankind was cast forth upon the storms and vicissitudes of property. Under the stress of such conditions he has passed through centuries of struggle and martyrdom, until he has tinally come to the last stage of his journey, and under the serenc skies of a more cquitable social system, he now sees peace and justice at last

economic form, we shall find both to be characterised by equality of conditions, and by the non-existence of capitalistic revenuc, and by social peace. The difference lies in the fact that under the earlier economic form a complete development of individual force could only be obtained by force, and individual well-being was, therefore, securcd at the expense of his subjection to the collectivity; but under the Hnal form, coaction of this kind will no longer be necessary, the reign of liberty will then be detinitely established. 
in the conditions of the earlier age, since ripened by civilisation. ${ }^{1}$

The premonitory symptoms of this final transformation are already to be detected in modern conditions. It is true our present society carries an appearance of vigour and vitality which seems to defy assault, but if we put our ear to this exuberant life, we can hear the slow rumblings of death destroying it from within. A splendid mantle covers our civilisation, but on looking more closely we see that it has already lost its sheen; its brilliant colours are beginning to fade, and ere long this splendid cloak will become the funeral shroud in which capitalistic society is to sleep its last. Under the apparent signs of health, science must look for the symptoms of disease, and watch for the premonitions of death. It should not, however, attempt to avert an inevitable destiny, but rather endeavour to moderate the convulsions which must inevitably accompany the birth of a new and more vigorous society. By confining itself to this task, science will accomplish far more than by proposing irrealisable plans of social reform.

1 This idea-also expressed by Cognetti de Martiis (Le forme primitive nell' evoluzione cconomica, Turin, 1881, p. 450)-is to be met with among writers of very different tendeneies and at epochs widely separated from one another-from Vico to Cernicewski. Aristotle himself said: "Res enim humanas et coeterarum eas qua naturalem motum et ortum ac obitum subeunt, circulum esse dicunt" (Physica Auscultatio, iv., 14). 


\section{CHAPTER VI.}

\section{IN ANSIVER TO SOME OBJECTIONS.}

Our theory has at least had the merit of calling forth numerous objections. The intrinsic value of these criticisms, as well as the eminence of the critics themselves, makes it incumbent upon us to reply. We cannot, therefore, bring our present inquiries to a close without first taking some account of these criticisms and endeavouring to answer them briefly.

And first we wish to exonerate ourselves from the charge of cynicism that we have incurred in several quarters on account of our moral and political doctrines. "A dismal doctrine," as our lamented friend Emile de Laveleye remarked, "which seeks to lower the dignity of the human race in our eyes by showing it to be governed exclusively by sordid material interests." I But alas! we must answer these belated moralists that the cynicism is inherent in the conditions themselves - which could not, indeed, be sadder-and not in the minds of those who frankly set forth the things as they are. A sorry cynicism is that which seeks to mask the horrors of contemporary society under fallacious thcories, and hide our inmoralities under polite euphemisms. Such is the kind of cynicism, however, which modern scholars are constantly guilty of, and consequently our researches do not meet with approbation. But the writers of former times proceeded in a very different way. Being inspired with a higher sense of their mission, these older writers boldly affirmed the true character of moral and political institutions. And in this connection it is worthy of remarli that several French writers of the last century fully understood the capitalistic foundations 
of modern morality and drew very interesting deductions therefrom. In support of our assertion we will not cite the names of Mably or of Morelly-who declared that egoism could only prevail as an ethical principle in a community of equals, and never in a capitalistic society-because the utopian ideals of these writers deprive their theories of scientific value. We desire, however, to recall certain words of D'Alembert, which go to show how thoroughly this dominant mind grasped the essentials of modern morality. On 29th January, 1770, this French philosopher wrote to Frederick of Prussia, who had questioned him concerning the foundations of morality, as follows: "In my Elements of Philosophy I took enlightened self-love to be the principle of all moral sacrifice. One point, however, has troubled me, Sire, in rendering this ethical principle absolutely universal and unrestricted, namely, to know whether those who possess nothing, who give all to society and to whom society refuses everything, can ever have any ethical precept except the law. How, indeed, can we expect to persuade these men that it is to their best interest to be virtuous when they might with impunity be otherwise? Had I been able to find a satisfactory answer to this question, 1 should long since have put forth my catechism of morals." In a letter of the 30th April following, after having stated that egoism justified the poor man in committing theft against the rich, D'Alembert added more explicitly: "It is true, Sire, that reasonable as the doctrine is, it is not proper to set down in a treatise or in a catechism of morals an account of the abuses that could be made of it by cupidity and sloth. This inconvenience makes it impossible to frame a complete system of morality for the use of all orders of society. . . . The answer to the enigma seems to me to lie in the fact that the distribution of wealth in society is monstrously unequal, and that we are compelled to sacrifice victims, innocent though they be, in order to prevent the poorer members of society from arming themselves against the rich, as they would be tempted to do, and, perhaps, have the right to do." I

¿Frederic II., Ocuvres posthumes, Berlin, 1791, vol. xx., pp. 99-107. 
The fact that prevented D'Alembert from completing his catechism of morality was precisely that upon which we insisted in the earlier part of this work, namely, the existence in every capitalistic society of a class of men deprived of their liberty of choice, whose self-interest incites to revolt, and who must, consequently, be led to obedience by a systematic perversion of their egoism. Those who have become convinced from our remarks will not, however, agree with D'Alembert that the morals of the rich class are determined spontaneously by their egoism, nor will they admit that the poor classes are held in check exclusively by the fear of punishment. On the contrary, powerful moral forces concur in moderating the conduct of all the different classes of society. But every one must at least accord this French writer the merit of having recognised that capitalistic property renders a morality founded upon egoism both irrational and unrealisable. Comparing this doctrine with those that are now-a-days displayed before the public, learned and ignorant alike, we must reluctantly confess that moral science has, in many respects, undergone an appalling retrogression. Surprising and contradictory to our optimistic illusions as this retrogression may at first sight appear, it is not, however, difficult to explain when we reflect a little upon the influences to which the human mind has of late been subjected. It may be traced back, indeed, to the well-known psychological law, that the mind is freer and follows the truth with more courage when social conditions render the practical application of its conclusions more difficult. On this principle, it is clear that the present tendency of putting ideas at once into execution, and the close connection that to-day prevails between theory and practice, must exert an oppressive influence upon the calmness and impartiality of theoretical expression. It is not so surprising, therefore, that the writers of the past century enunciated a true theory of morality, while our nodern theorists offer but an artificial counterpart. ${ }^{1}$

These historical comparisons, together with the multitude

' As a striking cxception we should recall Guyn's judicious observa. tions (La morale anglaise contemforainc, Paเis, 1879), which give evidence of profound insight into the truth of this debated question. 
of facts that we have brought forward (and the many others which the intelligent reader will easily be able to add), all go to support our thesis on the economic foundations of morality and the law. ${ }^{1}$ But still more serious objections have been raised against our inquiries regarding the economic basis of sovereignty. These criticisms, therefore, demand our special attention.

The fundamental idea of this work-that economic revenue is the basis of political sovereignty ${ }^{2}$-appears inadmissible to an eminent writer, Tarde, who assures us, on the contrary, that logically and historically it is political power that determines economic influence. No one, he says, can deny that the possession of political authority is, and always has been, the surest way of making a fortune. And as in our day politicians aspire to political power in order to acquire wealth, so, in the same way, the condottieri and the monks of the middle ages, though deprived of all possessions, succeeded to political power, and immediately made use of it to acquire a vast patrimony. Moreover, the bourgeoisie of this period only succeeded in

1 Thus, for example, the large number of astrologers and diviners in the west of the United States (Bryce, loc. cit., iii., p. 647) confirms what 1 say, namely, that the religious scntiment grows stronger where the struggle between man and nature is more doubtful. On the other hand, the falling off in the religious spirit among the labouring classes of the Old World-a fact that we have already mentioned-is confirmed from the data that Booth has collected regarding the morals of the working men in the East End (Life and Labour of the People, London, 1891, i., p. 119). On the other hand, the fact that in America no limits are set to the freedom of testation clearly confirms our statement that restrictions on the right of testation only arise where the field for the employment of capital is itself becoming limited, and it is necessary to check the progress of accumulation in every possible way. A large number of facts in support of my thesis are to be found in Seeley, The Expansion of England, p. $135 \mathrm{ff}$; in Jannet, Les Etıts Unis contemporains, Paris, 1889, i., pp. 154-55, 346 ; ii., pp. 50, 350; in Garlanda, La nuova democrazia Americana, Rome, 1891; in Rogers, The Economic Interpretation of History, London, 1888, etc. See also our Analisi, Turin, Bocca, ii., p. $146 \mathrm{ff}$.

${ }^{2}$ Lepetit (Il socialismo, Milan, 1S91, p. 62) reproaches me for considering sovereignty an appanage of land-rent alone; but 1 never said this. On the contrary, I affirm that political power goes with revenue, whatever its form. 
accumulating their small amount of capital after the Revolution had occurred which established the power and independence of the towns. If we go back to a still more remote epoch, this author continues, we shall find that the patria potestis, the primitive source of all authority, political, religious and judicial, preceded the property system and gave it birth. The primitive man had no property, he only possessed theocratic authority, which he exercised over his women, his children and his slaves, and this enabled him to capitalise the herds and cultivate the soil. It was, therefore, revenue which sprang from sovereignty. This is also evident a priori, for "sovereignty is a condition precedent to productive activity, militant or industrial, while revenue simply marks the limits of enjoyment and consumption; thus revenue must logically follow and not precede sovereignty". ${ }^{1}$

This last argument seems to us, however, to prove the very reverse of this eminent philosopher's proposition. If revenue marks the limits of consumption, it follows that those who are shut out of the revenues are deprived of the possibility of consuming, and must, therefore, seek this favour at the hands of the revenue-holders. How then can we suppose that a group of men, whose very existence depends upon the favours of another class, can resist the political aspirations of the latter and prevent them from acquiring power? This is evidently inconceivable, for the moment those shut out of the revenues attempted any resistance the other class would at once cut them off from their means of subsistence and reduce them to submission through starvation.

But, aside from this argument, Tarde's main proposition, that a class cannot acquire economic revenue until it has first gained possession of political authority, is also untenable. It is true that in order to secure an income from capital it is necessary to gain control over ofluer men, or in some way exclude them from the possession of the soil, but to accomplish this result it is not necessary to acepuire political power, for the property-owner's own forees, joined with those of the unproductive labourers, are sufiicient for the purpose. It is only after

'Revue Philosofhique', January, 1887. 
having possessed himself of the revenues that it is necessary for him to possess political authority in order to make sure of their continuance. Thus the group of adventurers who founded Rome first of all brought the inhabitants into subjection by reducing them to slavery, and it was only after this conquest had been effected that they secured the monopoly of political authority through the constitution of Servius. It also happens in our day, though rarely, that the working men, excluded from political authority from the very fact of their economic condition, succeed in acquiring a share in the social surplus; thus showing, in the most explicit manner, that one can acquire revenue without first participating in political sovereignty.

The facts set forth by Tarde in support of his proposition will not bear impartial criticism. It is, in the first place, absolutely untrue that the patria potestas was the original source of political authority; for sovereignty was established on the basis of mother right long before the patria potestas was known; and even among tribes recognising the paternal line political authority was already pretty well developed before the patria potestas was recognised. ${ }^{1}$ Moreover, modern research into prehistoric conditions-and Morgan's investigations in particular-has clearly shown that the patria potestas was itself but the corollary of private property, and that during the period of communal property maternal authority exercised absolute sway. This refutes the statement of our opponent that the patria potestas preceded private property, and shows that this ancient form of political authority was itself derived from economic conditions. History supports the views of this French philosopher no better than prehistoric research. History shows us, in fact, that the accumulation of bourgeois wealth,- which should, according to Tarde, have followed the political revolt of the towns, - on the contrary, preceded this event by a considerable period, and was, in fact, the cause of this revolution. For documentary proof of our assertion, it is sufficient to refer to the studies of Augustin Thierry and

${ }^{1}$ Sieber, loc. cit., p. 284. 
Monteil on the development of the third estate. Both these writers, after describing the accumulation of bourgeois wealth during the feudal period, and pointing out the growing contrast between the economic strength of the bourgeoisie and their lack of politica! power, show that this contrast culminated in the bourgeois revolution and disappeared entirely upon the liberation of the bourgeoisie from the yoke of the nobility.

Only one of the facts suggested by Tarde seems in any way to contradict our contention, namely, his reminder that the condottieri and monks of the middle ages participated to a considerable extent in sovereignty though they possessed no capital. This objection. indeed, applies to the first edition of our work, but it can be readily answered from the subsequent investigations we have made of the capitalistic function of unproductive labour. We have shown in our Propricté Capitaliste, ${ }^{1}$ and indicated in the preceding pages, that the revenues are not entirely ahsorbed by the owners of land and capital, but that a share is also acquired by the unproductive labourers necessary to defend the revenue system from the attacks of those excluded from landed property. The moment we recognise that men owning no capital may still participate in the revenues, we understand at once how these men may, and often do, share in political sovereignty as well. We can thus explain without difficulty the objection rightly raised by Tarde to the first edition of our work. This analysis of unproductive labour (which in our opinion possesses exceptional importance to a proper understanding of the structure of the various economic systems, and the relations existing between the different classes of society) also refutes other objections that have been brought against our hypothesis. In short, the criticism that Fioretti and other economists make against us for dividing society into two classes, the capitalists and the labourers, and for failing to take account of artists, lawyers, physicians, and liberal professions gencrally, seens to us absolutely untenable after the study we have recently made of the unproductive labourers. Pioretti also remarks that any theory based on egoism fails 
to explain the donations of land voluntarily granted by the seigniors of the middle ages to the churches and monasteries. ${ }^{1}$ But if our analysis of unproductive labour be correct, it was egoism again that induced these mediæval capitalists to surround themselves with this great legion of ecclesiastical clients. It was the special function of these men to assure the acquiescence of the labourers and the serfs in the economic system that exploited them, and this result could only be obtained by allowing the ecclesiastics to participate in the feudal revenues. To Sax's ${ }^{2}$ objection that an economic system based upon usurpation is impossible, because the exploited classes being the more numerous would easily succeed in overthrowing it, we answer, in like manner, that the force lodged in the numerical superiority of the exploited class is easily neutralised by the moral influences exerted by the unproductive labourers, who encourage weakness in the lower classes, and lieep them in a state of ignorance, in order to make sure of their acquiescence in the usurpatory system. And to Rabbeno ${ }^{3}$ finally, who finds it incomprehensible that the labouring classes, more and more degraded through the infiuence of the present system, should ever be in a position to overcome the owners of capital, and establish a higher social form, we have only to reply that, after the land has all been appropriated, a rise of wages above the bare minimum is no longer antagonistic to the interests of the capitalist, but actually to his advantage. This rise in wages will improve the moral condition of the working man, and make it possible for him to attempt an economic revolution. Besides, our analysis confesses that the working classes could not undertake the revolution without the aid and guidance of the unproductive labourers, who afford just the conditions of intelligence and culture requisite for the heroic work of social reform. Our analysis also shows how the unproductive labourers are urged to join their forces with the wage earners on account of the diminution of capitalistic revenue

Cultura, 1886.

${ }^{2}$ Sax, loc. eit., p. 110.

${ }^{3}$ Rabbeno, La funzione cconomica ilella vita politica (in the Rivista di Filosofia scientifica, 1836). See also Waltershausen, Moderne Socialismus in den Vereinigten Staaten, Berlin, 1890, p. 16. 
which diminishes the share going to capital's intellectual allies, and by the corresponding rise in wages, which increases the remuneration of the inteliectual allies of labour. ${ }^{1}$

The idea that the division of the legislature into two branches results from the bipartition of the revenues is also objected to by Tarde on the ground that this division already existed in the early period of the United States when capital had not yet acquiredi sufficient importance to allow it to make a successful stand against landed property. But even though no schism had as yet occurred between land-rent and the profits of capital in the early days of American development, a conflict nevertheless existed (as was also the case during the middle ages in Europe) between agricultural profits established upon servitude and industrial revenues acquired by free labour. This conflict was encouraged in the economic field through industrial protection and manufacturing monopoly, and formed the basis of the original distinction between the Senate and the Housc. Moreover, we have taken pains to point out that this division of the legislature into two branches only results from the bipartition of the revenues when one of the two revenue classes is in control of one house and the other of the other. But if, on the contrary, the dominant revenue happens to prevail in hoth houses, the division of the legislative body is in no wise connected with the bipartition of the revenues but merely an administrative device to lend dignity and weight to legislation. The same is true when only one form of revenue prevails, for there again technical rather than economic reasons lead to the division of the legislature into two branches.

Antonio Salandra in his admirable article on our worl ${ }^{2}$ raises

1 This accounts, at least in part, for what is called Catholic socialism. This may, indeed, result from the fact that a considerable number of ecclesiastics now live at the expense of the poorer elasses, and are consequently interested in protecting then. It is, nevertheless, true that if an adequate social system were established and if poverty were to disappear, the capitalistic functions of the clergy would come to an end, and their emoluments would likewise cease. For this reason, and all appearance to the contrary, the clergy will always stand out as the natural adversarics of every radical cconomic change.

${ }^{2}$ Giormale degli cconomisti, May, 1886. 
still other objections, equally as serious to our studies in finance. In answer to what we have stated above, ${ }^{1}$ he observes that if capitalists desired to put a check on accumulation in order to prevent a rise in wages, they could do so more naturally and more agreeably to themselves by enlarging their consumption, without resorting to the roundabout and disagreeable method of imposing an additional tax on their own income. Not only Salandra, but two other writers equally as talented, Fusinato ${ }^{2}$ and Rabbeno, have also raised this objection. The latter adds that he cannot understand what conscious motive induces capitalists to tax themselves in this manner when the real cause rendering such autotaxation advantageous to them, viz., the capitalistic necessity of reducing wages to a minimum, is obscured, and cannot for this reason act as a motive for their voluntary sacrifice. Though worthy of serious consideration, none of these objections are unanswerable, especially as we have elsewhere devoted such serious study to the laws of accumulation. In our analysis of capital we showed that the amount of wealth saved and devoted to reproduction stands in definite proportion to the rate of profits and is entirely independent of the beneficial or injurious infiuences that accumulation may exert upon capital. Accumulation, therefore, continues, even though by resolving itself into surplus wages it may be useless or actually prejudicial to capitalistic revenue. The moment we recognise that accumulation does not depend upon the will of the individual capitalist, but follows necessarily the variations in the rate of profits, we perceive at once that, the rate of profits remaining constant, capitalists cannot increase their unproductive consumption at the expense of accumulation, but must necessarily, though unconsciously, devote a definite amount of their wealth to accumulation. Hence there is no other way of checking accumulation than by lowering the rate of profits, and this can only be done by laying a tax on incomes.

In this connection it should also be remarked that the income tax is not, as our opponents seem to believe, something

${ }^{1}$ See p. 218 ff.

${ }^{2}$ Rivista italiana per le scienze giuridiche, 1886. 
entirely different from the extension of unproductive consumption, but, in reality, part of the same process; for to what purpose are the returns of the tax applied if not to the satisfaction of the collective wants of the well-to-do classes? What then is the income tax but a means of securing by force of law the expansion of unproductive consumption which could not be obtained from the capitalists voluntarily? Herein we find an answer (or at least it seems so to us) to Rabbeno's judicious observation regarding the lack of a conscious motive for autotaxation; for we now see that there is such a motive, and that it consists in the desire to increase the collective consumption of the capitalist class. But leaving aside this conscious motive, we can still detect another in the psychological connection which exists between phenomena and the immediate motives necessary to produce them. Thus the unconscious necessity of the autotaxation of capital is at a definite time, reflected in the minds of the capitalists as an abstract law of justice, which dictates a higher tax on capital. This idea of justice suddenly cropping out, offers an immediate and conscious inducement for capitalists to lay a tax upon themselves, though it is at bottom in their own interest.

Herzenstein, who bas written a long and brilliant criticism of our work in the Penséc russe, passes rather arbitrary judgment upon our theory of taxation, and especially upon our explanation of the income tax, and the tax on the operations of the Bourse.' In so lar as the latter is concerned, however, Roscher himself has remarked that this tax is due entirely to the influence of landed proprietors and their aversion toward the capitalists. And, in our opinion, the numerous facts with which we supported our assertions in regalsd to the income tax are in themselves sufficient to defend our proposition from the criticism of this eminent Russian publicist. Nor doe's it appear more difficult to reply to still another criticism raised against our theory of finanee. It has been said that our explanation does not go back to the first causes of financial phenomena; ${ }^{2}$ but this is wrong, for our theory determines with the greatest

'Russkaia Misse, March, 1890.

${ }^{2}$ Ricca-Salerno, Giornale degli economisti, July, 1887. 
exactness both the quantity and the value of public services, and connects each with the economic conditions prevailing at different social epochs. Unquestionably, financial phenomena are only connected in this way with a further cause which is itself far from simple and susceptible of still further analysis; but the same may be said of all the political phenomena that we have represented as the outcome of economic conditions. This admission does not, however, justify the criticism aimed at us by the eminent philosopher Icilio Vanni, who protests that an explanation which has itself to be explained is no explanation at all; nor does it support the objection made by Adolph Wagner, who thinks that the materialistic interpretation of history only substitutes for one mystery another which is equally as unintelligible; nor finally does it justify the reproach that Philippovich hurls at our theory, of resting on nothing because it fails to explain the economic conditions which it lays at the foundations of society. ${ }^{1}$ It seems to us, on the contrary, that it is always scientifically useful to demonstrate that two phenomena apparently disconnected are in reality the cause and consequence of one another, for in this way the search for the original cause of the phenomena in question is considerably simplified by being limited to the study of a single category in place of two as before. The sciences progress through simplification and by reducing the most diverse phenomena to a single fundamental fact. It is, indeed, only through simplification that science approaches the truth, for it is only in the simple that the truth is to be found. As Kant has said: the reduction of terms is not only an economic rule of reason, but furthermore an innate law of human nature.

Along with these criticisms of our particular views, others have been offered, more eclectic in character, which accept some parts of our thesis and reject the rest. Maurice Block, with his characteristic charm of style, has compared our book to " a jewel which seems all gold, but is hollow in part and

${ }^{3}$ Vanni, Prime linee di un programma critico di sociologia, Perugia, 1888, p. 43. Wagner, Grundlegung der Politischen Oekonomie, Leipzig, 1892, p. 239. Philippovich Grundriss dcr Politischen Oekonomie, Freiburg, 1893, p. 50. 
filled with baser metals". ${ }^{1}$ And several other writers, sharing his point of view, have admitted the application of our theory to one social period, but denied it to another. It is unfortunate, however, that our adversaries could not have come to an agreement among themsclves in this matter, so as not to find themselves in such striking contradiction. To Salandra, for example, our theory appears applicable to the present period, dominated as it is by material interests, but false for past epochs, which were influenced by nobler sentiments. Philippovich, on the other hand, declares that economic conditions only determined political and social relations in the past, and that they no longer exert such influence, because, in his opinion, the progress of civilisation has tended to withdraw politics from under the action of utilitarian calculation in order to direct it toward loftier ideals. These two criticisms, equally forcible, and running in opposite directions, mutually destroy each other, as we see and demonstrate the lack of any principle of continuity in the evolution of sociological laws.

But a much more serious accusation has been raised against our theory. From several quarters we have been reproached for being one-sided in our views, because we fail to take account of the moral, religious and civil factors, which, along with economic facts-and sometimes more efficaciously than they-determine the dynamics of humanity. Thus Tarde says it is a mistake to leave out of account the ideas that have successively taken root in the human mind. "So long as the aristocratic period of society endured, birth alone gave the right to rule, and the smallest drop of noble or royal blood was worth more to ambitious men than any amount of treasure. Why? because it was essential for a pretender to be considered a legitimate successor, and the idea of legitimacy was then connected with blood. How many thrones have been firmly established on this prejudice, independently of any clesire on the part of the people, and even in the face of pronounced antipathy on their part! That candidate always had the best chance who conformed most closely to the religious and politi-

1 Fournal des Economistes, 1886, p. 71. 
cal standards rather than the material interests of his electors. A man does not always believe what it is to his interest to believe. His belief and his desires are two different things, and it is fortunate for the governed that such is the case. Had the ruling property owners no other end in view than to preserve and increase their wealth, we should expect them to adopt stronger measures to attain this end, and not hesitate in their choice of the means. But the transition from slavery to seridom, and from serfdom to the wage system, would be absolutely inexplicable on these grounds; for how did power come to slip from the grasp of wealth and intelligence during these critical periods? Ideas unconsciously infiltrate through the intelligence, ultimately penetrating into the minds of the oppressors themselves, and by this slow process the face of the earth is changed. Why have not the majority continued to exploit the minority, as they could have done by keeping them in service or serfdom? Simply because new principles have taken hold of the minds of men, and this is the invisible restraint that human development involves. Abstract principles and concrete purposes are established independently of one another, and, once formed, develop along two independent lines : the principle, along the path of logic, according to the invariable axiom that "he who states the premisses gives the conclusion"; the purpose, by way of theology, utilitarianism, economics, if you will, according to the maxim "he who wishes the end desires the means". "And thus social movements are religious or philosophic, like the Reformation or the French Revolution, which no utilitarian considerations can ever succeed in explaining, or great economic transformations ... At times these two evolutions are independent, at times they touch each other, mingle and cross one another; sometimes the one and sometimes the other predominates in the direction of public affairs, but never the one to the entire exclusion of the other. I maintain we should congratulate ourselves on this; for, on the one hand, it is the obstacles opposed by practical necessity which prevent the fanatic from carrying the articles of his faith to a disastrous conclusion; and, on the other hand, it is the slame of too openly contradicting himself that restrains even the least 
scrupulous politician from employing certain means that are useful to his ends but condemned by his conscience. If it be not a sense of shame, it is at least the fear of being blamed and repudiated by his party which stamps this miserable falsehood on its face. The most haughiy despots would not become fanatics but sceptics, I fancy, if the sceptics' will did not evidence a lack of virile thought, and if sceptics did not generally show themselves equally as inconseguent in the pursuit of their ends as in the application of their principles." 1

This is, indeed, a fine page, and Salandra's criticism, written in the same vein, is no less clegant. "In the interests of scientific truth and the soundness of our own judgment, we cannot be content with a single cause, and in this particular case we cannot except the economic causc. If hunger be a natural phenomenon, so, happily for human nature, is faith. These arbitrary linitations of our nature, this search for a single cause, which does not appear more scientific simply because it is base, reduce themsclves finally to a métaphysique it rebours, a theology of the appetite, and make us wish for the old metaphysics and the old theology. If humanity is one day to be recluced to choose between your philosophy of history and that of St. Augustine and Bossuet, let us hope it will repudiate the scholars and economists and pin its faith to the saints. . . Poo: modern science! It is obliged to accept the heritage of the sophists. MI. Loria explicitly endorses the remark of the most antipathetic of all the interlocutors of the dialogue of the Republic, Thrasymachus of Chalcedon, who affirmed that justice was the interest of the strong. But

Tarde, loc, cit. Several such criticisms have also been offered by Bela Foldes in an interesting analysis he has made of our work (Annules d'Economie politique d'Fina, feloruary, lisis, hy liaial in the same review (December, 1887); by Cossa, lece, cit., p. 28; by Dalla Volta in the

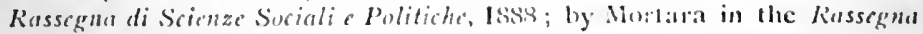
critica di opere filosofiche, etc., 1887. Sec also the long review of our

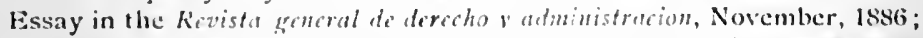
Miraglia, "Le teorie di speneer, di George e di Loria" in the Memorie

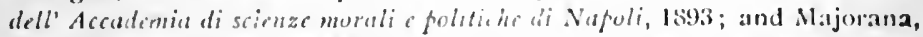
"Lat teoria sociologica della constifuzione politica" in the Antologia Giuridica, 1892, 1893. 
while recalling Thrasymachus, why did $M$. Loria not challenge Socrates' successful refutation of the proposition? Why did he not seek in another of Plato's dialogues that sublime scene-the grandest that history or legend has recorded after that of the death of Christ in expiation of the sins of manwhere Socrates, in respect for the laws of his country, tranquilly refuses to escape the iniquitous sentence? No, on Golgotha and in the prison of Athens it was not economic imperatives that commanded." 1

It is impossible to stem this torrent of criticism with a single wall. We prefer, therefore, to examine the objections one hy one and refute them separately. In the first place, those who maintain that human acts are dictated not by interest alone. but also, and still more powerfully, by beliefs and ideas, should ask themselves whence come these beliefs and ideas? To those who follow the positive method, as I understand it, beliefs and ideas are in no wise spontaneous phenomena, but necessary products of the social environment. Hence to say that human acts are the immediate outcome of belief only goes to strengthen the proposition that they ultimately result from economic conditions. We demand again of our adversaries how it happens that the beliefs and ideas prevailing at different epochs, though radically unlike, are always of such a nature as to strengthen and support the then prevailing economic system. Why was it that the ethics of the sword ruled in the ancient world just when it was necessary to hold those excluded from the possession of the soil in submission by force or a show of force; why did the morality of the Cross prevail during the middle ages when religion sufficed to keep the disinherited classes in obedience; and why does social morality rule supreme in modern society where the acquiescence of those excluded from possession of the earth is secured by the force of public opinion? Does not all this show in the clearest manner that beliefs are not heterogeneous phenomena entirely disassociated from economic interest, but, on the contrary, derivative and unconscious symptoms of such interest, serving 
to satisfy it more completely? Unquestionably, in a large number of cases belief does enter into conflict with individual interests and repress the appetites; but these restraints upon the individual's activity are necessitated in the interests of his class, which cannot be fully satisfied until the indulgence of individual egoism is wisely restrained. It is accordingly always class interest, if not the interest of the individual, which determines the ruling beliefs of any social epoch. But even supposing beliefs and ideas to develop independently of economic interest, and to have their roots in entirely different soil ; and admitting, for the sake of argument, that a large number of acts do not correspond to economic interest at all but to other motives, such as ambition, villainy or love; what we still affirm is that these motives only influence the political history of peoples in so far as they prevail among the ruling classes. In other words, it is not beliefs and ideas in general that constitute a factor in history but only the special beliefs and ideas of the proprietary class. Beliefs and ideas were also present in the hearts and minds of the slaves, the serfs and the wage earners, but these beliefs and ideas have had not the least effect upon the march of history, for they have always been repressed by the beliefs and ideas of the patricians, the feudal lords and the capitalists. Thus even denying that this different way of feeling is due to the economic condition of the different classes, it still remains true that the economic situation of the different classes alone determines which set of moral ideas succeed in exerting its influence upon the history of mankind.

Coming now to an examination of the historieal facts which have been arrayed against us, we are able to detect the error of those who attribute social changes to beliefs and ideas. Strange, indeed, that a philosopher of Tarde's ability, in order to uphold his proposition, should find himself constrained to repeat, with the ingenuousness of a novice, the ancient legend of the transition from slavery to serflom being effected through the inlluence of faith. ${ }^{1}$ We have only to remark that the same social forms, which were supposed to have been entirely de-

${ }^{1}$ And so, too, Zorli, Teoria psicologica della Hnamza publica, p. 31. 
stroyed in Europe under the influence of the new religion, reappeared in the New Worid under the empire of these selfsame beliefs, and attained a vigorous growth. It is also worthy of note that in Europe itself the ministers of this religion were the warmest partisans of slavery, and the most pitilesss lave masters. And our opponent seems to forget that neither slavery nor serfdom were abolished until they ceased to bring any particular advantage to the proprietary class. I deem it useless to linger any longer over this point upon which 1 have insisted so strongly in my Propriéte Capitaliste. I will add, however, that I consider Tarde's assertion that the Reformation and the French Revolution cannot be explained on utilitarian grounds erroneous. The Reformation--and I insisted upon this point also in the above-mentioned bookoccurred as the result of an essentially economic conflict between the feudal lords and the ecclesiastics who protected feudal property from the attaclis of the seris. The feudal lords endeavoured to exclude the ecclesiastics from too large a share in revenues from property, while the clergy, relying on the precious support they lent to the feudal system, pretended to an augmentation of their rewards. Every one knows that the Reformation began with a reaction on the part of the property owners against the sale of indulgences, and that the first victory of the proprietary classes over the ecclesiastics was followed by an alliance between the latter and the serfs, which gave new life to the Peasants' War. As for the French Revolution, the essentially economic character of this great movement has been thoroughly recognised ever since SaintSimon traced its course, and other more recent historians have emplasised this point of view. The French Revolution amounted to nothing more nor less than the political revolt of the bourgeoisie, who were already in possession of capital and its revenues, and aspired to their natural complement, political sovereignty. This is the view of the French Revolution that we have adopted, and we do not believe it can be set aside hy the apodeictical remarks or apothegms of any philosopher, however eminent and however profound his knowledge of history and human nature. 
Nor do the facts set forth by Salandra in the fine passage we have quoted seem to us to controvert the economic concept of history. On the contrary, they only offer new and striking demonstration of the theory. We are perfectly willing to agree with Salandra that economic motives did not prevail on Golgotha and in the prison of Athens if he means by this that they did not directly inspire these two heroic sacrifices. The sublime conduct of the reformer who sacrifices his life for the idea that burns within him is certainly the product of a lofty ideal and not the result of cconomic criteria-no one would ever think of denying this. But the economic germ is, nevertheless, to be discovered in the objects of the reform movement, in the hostility which it meets in the ruling classes, and in the miserable lot reserved for the reformer. The calm intrepidity with which the reformer suffers martyrdom, the stoical dignity of the inspired apostle who "mounts the pi!e like a deputy mounting the tribune,"-all such things are the fruit of a lofty character in which no economic motives enter. But the martyr himself is a product of his social environment and the political preponderance of property in one of its forms. From this point of view we may, therefore, say with truthbecause it is an undeniable fact-that economic motives did predominate both on Golgotha and in the prison of Athens, since it was the reaction of property against threatened socialistic reforms which brought Jesus to the cross, and Socrates would never have been led to his sad fate had not the dominant democratic class revolted against the oligarchic suggestions of this great and pure-minded philosopher.

One word more in this connection, in reply to the assertions of an illustrious writer who insists in opposition to our theory, that modem social legislation and all the measures recently enacted in favour of the poorer classes are not the outcome of a conflict between the two kinds of revenue, but the result of a growing spirit of charity and philanthropy anong the proprietary classes. ${ }^{1}$ It would seem as though the facts and

"Luigi Luz»atti, "Le classi dirigenti c gli operai in Inghiltera" (Nuor'a Antologia, 16th November, 1892). This same objection has been 
observations offered in the course of this work ought to be sufficient to answer this assertion, but, by way of addition, we will submit a brief reply. If the proprietors were really dominated by feelings of pity and justice toward their labourers, why then are these sentiments smothered, and how comes it that all traces of legislation in favour of the needy classes vanish as soon as peace is concluded between the two factions of the proprietary class? If labour legislation be the fruit of moral sentiments and religious fervour, how does it happen that in pious Belgium, in devout France, and in Catholic Italy legislation of this kind excites so little serious interest. And why, if capitalists and proprietors are really moved by sentiments of charity and kindness toward their employees, is there any necessity for social legislation at all ? Is it not perfectly evident, on the contrary, that the very necessity of social legislation shows a lack of those spontaneous sentiments of kindness which optimistic science attributes to the more fortunately situated members of society?

Taking all these things into consideration, and after as conscientious an examination of the matter as we are capable, it seems to us that though this accusation of one-sidedness may perhaps be justified in a way by some too positive statements of ours (which we have sought to modify in this edition), it cannot, however, be applied to our main proposition, which appears to us irrefutable.

But another objection, equally as serious, has been raised by Herzenstein. "If," says he, "the theory of the economic concept of the State be true, we are forced to the conclusion that the whole process of evolution is rigorously determined, and that any alteration of the normal process is impossible. There is no sphere left for the free will of man. The whole

raised by another distinguished writer, Petrone, in his interesting essay on "La filosofia politica contemporanea" (Rivista di Giurisprudenza, 1892). Luzzatti's proposition has been recently combated by Bissolati, "La lotta di elasse e le alte idcalita della borghesia (Critica Sociale, December, 1892, January, 1893). Stringher, also, has much to say in favou" of our theory. Sce his brochure, "Sulla depressione industriale," extract from the Nuova Antologia, 1887. 
development is determined by objective factors, which are more powerful than the subjective desires of mankind, and we must, therefore, bow before history and accept what it brings. If, perchance, this passive condition be interrupted by any sudden outbreals or active ebullition of the human passions, by some altruistic impulse for example, the ideal is quickly followed by disillusion; for the man who is unwilling to submit to the fatal progress of evolution, desiring to direct social life according to the higher principles of equity and humanity, must recognise in the end that he is after all only an instrument, and that all his efforts are of no avail to the class in whose cause he has enlisted, but always redound to the advantage of that class which history is bringing to the front. Now, we ask, what other outcome is there from this point of departure except indifferentism and quietism? Sctting out with this idea of perfect regularity, can we arrive at anything beyond complete and absolute submission to the existing order of things? Such is the only legitimate deduction to be drawn from this concept. It is not surprising, therefore, that the most consistent writers holding this point of view fall into absolute contradiction with their own doctrincs. When M. Loria tells us in melancholy accents that those who have sacrificed themselves for glorious ideals really gave their lives in the fulfilment of a process running absolutely counter to these ideals, are we not authorised in saying as much of all contemporary movements performed in the service of noble aspirations? M. Loria protests, it is true, against this deduction, and, foreseeing that conclusions leading to quietism are sure to be drawn from his premisses, he makes strenuous efforts to show that his theory still leaves a wide margin for social activity. But he does not succeed in demonstrating the fact; the objection is merely foreseen, not avoided. On the contrary, his reply, which contains more dialectic than proof, shows us that either his theory is not sufficiently established, or that he himself has not the hardihood to draw the final conclusions. All M. Loria's active nature rebels against the quietism his theory imposes. In his conclusions there is an echo of a deeper sentiment which does not escape the reader. The hardy initiative of the man is 
in revolt against the narrow limits within which materialistic science wishes to confine human life." I

But can we really say that a doctrine leads to fatalism which concedes a fertile field to human activity, and which only seeks to mark out the limits within which such efforts may be applied? Can we give the name of quietism to a theory whose efforts lie in the direction oî substituting enlightened action, conscious of its ends and aims for blind, ignorant innovation which is powerless to realise its purposes? If we but take the trouble to examine the economic theory of politics ever so supernicially, we shall see at once that it admits of two distinct sorts of legislative action calculated to soften the severity of the economic system and to some extent modify its structure. In the first place there is abundant opportunity to ameliorate the sanitary and economic condition of the poorer classes without in the least interfering with the rights of property, and measures of this kind are in no way excluded by our theory. On the contrary; our theory shows that such iegislation is the necessary result of the conflict between the two forms of capitalistic revenue. The possibility of reforms built on air and arbitrarily conceived is, indeed, excluded by our concept ; but, at the same time, the reformer is enabled to see how he may make sure of the success of his plan by allying the owners of one kind of revenue with the labouring class and by provoking a contest with the other lind of revenue whose inevitable result will be the moral and economic elevation of the poorer classes. Turning, in the seccnd place, to the great social transformations which alter the structure of property, our theory does, it is true, deny that such morements can be effected before the necessary change in economic conditions has rendered them inevitable; but far from this conclusion leading to the degradation of human nature, it seems to us to inspire the highest sentiments. If we examine the great spontaneous movements that have sought to modify economic conditions before their time, we shall

${ }^{1}$ Herzenstein, loc. cit. Analegeus objections have bcen made by Caldara. "Del concetto di liberta nell" er dine ccononico" in the Pensiero Ituliano, 1S92, p. 493, fussim. Sec also Caporali's remarks in the Nuova Scicnza, 1886, 1891. 
find that they all lacked definite purpose. There was no clear idea of the new order of things to be substituted for the old; and on this account these movements lacked discipline and order: they were anarchic, and hence their want of effect. Our theory, on the contrary, declares that it is first of all necessary to learn the nature of the future social system and, after this knowledge has been acquired, to substitute a co-ordination of efforts toward this definite and rigorously determined end for the blind and disorganised attempts that have thus far been made in this direction. Instead of restraining the noble outbursts of those who aspire to a higher social order, this concept should rather enlighten and discipline their efforts; that is to say, it should arouse in them the attributes which alone can secure success. This in no way precludes the possibility of reform. On the contrary, by pointing out the proper way, it prevents the reformer from wandering forth into the sterile fields of illusion and keeps him in the narrow path leading toward the truth. Instead of leading toward fatalism, our theory, on the contrary, tends to encourage rational human activity, which alone can prevent, or at least mitigate, the confusion otherwise attendant upon social metamorphosis. ${ }^{?}$

The ideas developed in the present work on this particular point are more fully illustrated and confirmed in our Analysis of Capitalistic Property. In brief, the results of this analysis are as follows: the present suppression of the free land, obtained by means of an exclusive appropriation of the soil, tends to reduce the rate of profits below the minimum, and thus render the very existence of a capitalistic economy impossible. Becoming thus inadequate at a certain stage in its development, the capitalistic economy must eventually give way to the final economic form," based upon the free owner-

'See the finc ohservations of Vanni, Il froblema della filosofia del diritto, 1891, p. 58 ff.

${ }^{2}$ The very idea of an ultimate economic form is inacceptable to several dislinguished writers, and, among others, to Fusinato. But as it is now admitted by anthropologists that organic crolution has a limit, and that it is no longer producing sensible modification in the human 
ship of the soil, or, in other words, to a voluntary system of co-operation between the producers of capital and the ordinary labourers. If left to the operation of economic forces this transformation would involve antagonism and confusion, but it may be effected more quietly through the intelligent efforts of man. A wide field is thus opened to human activity, and it is certainly a noble mission for mankind to withdraw social development from the operation of the blind and brutal forces of physical evolution and submit the process to the kindlier and more civilised action of intelligence and reason. One may say that the task set for social reform is thus limited to narrow proportions, but one must admit that the problem is thereby made more concrete, for there is at last some definite object in view. According to our analysis, economic reform ought to limit itself to the single task of re-establishing free land in a rational and voluntary way; for otherwise the result will be reached by a natural process bringing with it confusion and disaster. Science and practice have, accordingly, to propose the best means of re-establishing free land and replacing the present capitalistic system with a voluntary association of labour. Such is the high mission our theory confides to collective activity. We see then how ill-founded is the accusation that our doctrine leads to fatalism, and proclaims human effort in the domain of social legislation useless and vain.

Thus, unless describing the orbit within which a reform may move can be considered as equivalent to excluding the possibility of reform altogether, no one can possibly tax our theory with the imputation of fatalism. Those who still accuse us must, therefore, be labouring under the old delusion that they can modify the structure of society as they will by following the fantasies of their own minds. The socialists of the Chair seem to us to fall into this error, and it is against them especially that we have directed our criticisms. It is true,

species, we may wcll recognise with John Stuart Mill that economic development is likewise limited,' or, in 'other words, that economic evolution will reach a state of equilibrium and stop there, marking at this pause the beginning of new developments of a higher and more peaceful order. 
Herzenstein reproaches us for this polemic, which he considers useless and inopportune. In his view, the socialists of the Chair do not pretend to radically and arbitrarily change the property system; they limit themselves, he says, to plans of partial reform, a large number of which I myself have subscribed to in the course of this work. But we take issue primarily with the economists of this school on their fundamental idea of economic reform. They malse reform depend exclusively upon the laws of the State or upon the will of man, while we regard such movements as the natural result of economic conditions. It is true sevcral adherents of the new school do confine their propositions of reform to certain halfway measures not calculated to alter the essence of the capitalistic system, but one cannot say as much for all of them, and certainly not of Adolph Wagner, whose proposals are frankly radical, as, for example, his idea of a social tax and the socialisation of fields and houses. ${ }^{3}$ Besides, the greater or less extension given to the various plans of innovation, proposed by the economists of this school, depends entirely upon the personal inclination of their authors, which differ widely, and is never the result of that consciousness the writers should possess of the existence of an organic law which presides over economic development. The ruling idea among all these socialists of the Chair, however varied their different shades of opinion, is that economic reform is confided exclusively to the decision of the State, which may give to the movement any character it pleases. Among none of these writers can we detect even the germ of an idea of the coming social form, and yet a conception of this kind is indispensable to any one who wishes to offer a feasible plan for social change. It is against this concept, so unscientific, and so hostile to all true reform (since it removes the possibility of its realisation), that we have directed our attacks; and, in offering these criticisms, we believe we have rendered a real service to the cause of social reform, whose success we have endeavoured with the best of our ability to advance.

Sce the 3rd ed. of his Grundligung that has recently appeatred. 


\section{CONCLUSION.}

\section{ECONOMICS THE BASIS OF SOCIOLOGY.}

Founded as it is upon the violent suppression of the free land, capitalistic property is only able to persist by means of a series of what we have called connective institutions, which are non-economic in character. These institutions are designed to discipline the egoism of the proprietary classes, and so vitiate the egoism of the labouring classes that they will be induced to put up with an oppressive economic system against which they would surely rebel if they were to follow their own interests. Morality, law and politics are the most important of these connective institutions. All three depend upon the economic, environment and all proceed logically from the conditions which make for the persistence of capitalistic revenue. Thus all the non-econonic factors running through the social system would seem to be ultimately derived from underlying economic conditions which alone furnish an adequate explanation of their complicated mechanism.

This assertion that the diverse manifestations of social life may all be traced back to a single instinct and a simple motive seems at first sight irreconcilable with the multiplicity of sentiments that apparently dominate mankind. On first view it, indeed, appears contrary to the facts of the case that, with the one exception of the desire for wealth, all the other human passions only appear in the social drama as silent supernumeraries. But this apparent contradiction disappears at once when we take into consideration the artificial character of the capitalistic system. After we have once thoroughly grasped the truth that capitalistic property is not a natural phenomenon but a violation of law, both human and divinethe impossible erected into a system-we shall be able to understand how in order to guarantee the persistence of so 
absurd and contradictory a system it is necessary to draw upon all the passions and sentiments of human nature, corrupt them at their purest sources and divert them into the service of this monstrous engine of iniquity. It is not so strange, therefore, that morality, law and politics, in fact all the varied manifestations of social life, have in time become impenetrated, polluted and transformed by capitalistic influence and made to harmonise perfectly with its evil designs. Nor is it so surprising that the capitalistic economy, itself organically contradictory, has engendered a corresponding contradiction in the varied elements of social life. All these contradictions and absurdities will disappear, however, with the advent of the coming social form. In the economy established upon equality and association social relations are self-adjustive and do not have to seek support in the perversion of the normal manifestations of human nature. Under this pure economic system morality is simply the natural and spontaneous emanation of enlightened self-interest ; the law reduces itself to a simple guarantee to the producer of the product of his own labour, and politics proceeds naturally from the general will. The capitalistic taint now pervading these institutions will, in other words, disappear entirely upon the cessation of capitalistic property, and leave the social spirit susceptible to the innumerable genial influences of which human nature is capable. Morality, law and politics will still remain the connective institutions of society, but, instead of heing placed at the service of the economic interests of one particular class, they will benefit humanity as a whole and aid in developing its higher destinies; instead of forming the gluten of a tainted mass, these institutions will hold together a healthy hody; instead of acting as cement to an aristocratic edifice, they will maintain the more perfectly proportioned structure of Human Equality.

In conclusion, it will be well to add another remarls in answer to the modern sociologists. They affirm that this idea of the dependence of social relations upon economic facts must be rejected on the ground of modern evolutionary science; for, according to this theory, society is an organism, and in an organism we have simply the reciprocal action and reaction of 
the component parts, with no one part dominating over another. ${ }^{1}$ And yet it seems really incredible that modern sociologists, imitating in this the metaphysicians of old, should presume to decide questions so difficult and complex with the help of mere empty phrases which are passed on from one writer to another like a literary trust. They pretend, for example, to determine this important question with the decisive apothegm: society is an organism. Whether society be or be not an organism, I, for one, must confess my inability to decide; and it is probable that those who answer the question in the affirmative have no very definite idea of what they mean. Herbert Spencer himself frankly admitted that he used the phrase social organism in a tentative sense, as a figure of speech which allowed him to present the life of society in a striking way and in plastic form. But his disciples, less circumspect and prudent than their master, affirm on every occasion that society is an organism. What do they really imply? If they mean by this that human society is subjected to laws of its own which develop automatically, and against which man cannot rebel, or if they intend to imply that society is no mere product of human artifice, a machine that man may destroy or alter at his will, but a product of nature, possessing a structure of its own and subjected to normal laws of development and decline, they are simply asserting a self-evident truth that has long been recognised. But this truth stands in no manner of contradiction with the fact established by experience that social laws proceed from economic causes. Nor does this latter fact in any way interfere with the analogy, so dear to some, between society and an organism. ${ }^{2}$ In the individual organism there are vital organs without which life cannot be maintained, and secondary organs whose destruction neither destroys nor abbreviates the life of the animal. We need not be surprised, therefore, to find the same thing occurring in the

I See, for example, the objection raised on this ground in the Archiv für soziale Gesetzgebung, 1892, v., p. 3.

${ }^{2}$ The favourite analogy between society and an organism has been recently very well criticised by Gunton, Principles of Social Economics, New York, 1891, p. 305. 
social organism. Here, too, there are the necessary and primordial organs, which we call the economic elements, and other organs derived from these, under which we include all the remaining factors of super-organic life.

When these truths have once taken firm root in the minds of the intelligent classes (it is doubtful, however, whether this will occur for some time to come) it is to be hoped that the prejudices still prevailing in the moral sciences will disappear. It will be no longer possible then for writers of authority to hope to effect economic perfection through moral reform, or by modifying of some article of the code, or by changing the political constitution. Every one will then understand that morality, law and politics are the effects and not the causes of economic conditions. Modern socialism, that hopes to innovate the social system by creating new laws, will then be regarded as a sterile utopia. When vivified by this economic concept, ethics, jurisprudence and politics will at last become positive sciences and rest upon the solid basis of reality. Men will then cease to speak of an absolutely imaginary society, as they are now in the habit of doing. At the present time, indeed, the theorists of these sciences reason as though socicty were composed of men who are independent of one another, who are endowed with equal economic force and who possess the same political power. But in reasoning thus they forget the inherent differentiation of capitalistic society, and leave sut of account the relation of dependence in which the greater number stand to the few, although these facts lie at the root of modern society and determine its laws. They fail, in short, to comprehend that morality, law and politics do not relate to society as a uniform whole, but only to the proprietary class which is able to fashion diverse social institutions to suit its own fancy. These theorists are thus forced to make of their science an eternal utopia, because the optimistic laws they elaborate in their minds and apply to a nondifferentiated society come at every step into contradiction with the phenomena of capitalistic conditions. But once the present capitalistic basis of ethics, jurisprudence and politics is recognised, we shall witness an unexampled renaissance of 
these noble sciences, which will then emerge from their inmediate position and move forward along new and higher lines.

The positive study of capitalistic property makes it possible to reduce the most diverse manifestations of social life to their lowest terms and analyse them scientifically, thus enabling us to give a scientific basis to sociology. It is, indeed, only by thus connecting social relations with their economic antecedents that sociology can ever assume the character of an exact science, like political economy, and divest itself finally of its present inorganic nature. But we cannot trace back modern social relations to their economic antecedents without recognising at once that capitalistic property is the result of usurpation and that in order to continue it must force the most diverse elements of human activity to co-operate in the realisation of its ends. On the other hand, should we prefer with orthodox economists to regard capitalistic revenue as the natural and legitimate reward of abstinence, endurance or any other effort, the possibility of affording sociology an economic foundation and therewith raising the new doctrine to the dignity of a science is at once eliminated. If the income from property were really the legitimate reward of abstinence on the part of the capitalists, there would then be no necessity for resorting to moral compulsion in order to hold the working classes in obedience; for, being the victims of no form of usurpation, the labourers would have no incentive to revolt. And, on the other hand, if the working classes were not deprived of their liberty of choice, and were really as free as the proprietors themselves, it would be impossible for the latter to lay exclusive hold on political and juridical power to the exclusion of the labourers. If this were the case capital would have no motive in creating connective institutions to maintain cohesion in the property system, as such cohesion would result spontaneously. Nor would the possibility remain of establishing such institutions to the injury of the labouring classes since they, being on a plane of perfect equality with the owners, would quickly discover a way of circumventing any such pian. Thus those who adhere to this optimistic theory of distribution 
must remain incapable of tracing social relations back to their economic origin ${ }^{1}$ and giving sociology a scientific character. It is not surprising, therefore, that where the optimistic theory of distribution still prevails sociology still lacks a scientific foundation, and is now-a-days reduced to an incoherent salmagundi of heterogeneous information, a collection of intellectual commonplaces, a fit resort, indeed, for the proletariat of the thinking world. Thus, to the nany sins of this optimistic school, we must now add another: the inanity of modern sociology.

Thus, in the natural order of things, a systematic falsification of economic relations has resulted in the impotence of the science of sociology. But one of the greatest merits of the exact theory of distribution, and of political economy in general, will be to lay a firm foundation for this social science. During the last days of capital sociology will then form the moral science par excellence, even as law represented the culminating point reached by social science during the period of property's infancy.

${ }^{1}$ The few writers who, while following the optimistic theory of distribution, still affirm the economic basis of sociology, cannot procced a single step beyond this bare assertion and find themselves unable to incorporate the idea in any convincing theory. Thus De Johannis in his interesting work, Della universalita e preminenza dei fonomeni cconomici (Rivista di filosofia scientifica, 1883), and De Greef (Introduction ì la sociologie, 1886), both affirm the dependence of social facts upon economic conditions, but their remarks on this subject do not go beyond ornate platitudes of literary phraseology. The superficial character of these rescarches comes out most clearly in the observations of the latter on the above-mentioned writers. Carrying out Hertzberg's idea (which we have combated above), De Greef belicves that the most profound economic facts, and those which form the basis of all sociology, are the phenomena of exchange. And why? because roads, canals, banks, cte., are the most flrmly established economic organs (luc. cit., i., p. 193). But these, on the contrary, are the most superlicial and complex of alt social phenomena, and owe their greater perfection and more elaborate structure to just these characteristics ! 



\section{SOCIAL SCIENCE SERIES.}

SCARIET CIOTH, FACH 'S. lid.

1. Work and Wages.

Prof. J. E. TIOOROLD ROgERs. "Nothing that Professor Rogers writes ean fail to be of interest to thoughtful people."-ither:artm.

2. CIyllisation: Its Cause and Cure.

"No passing piece of polemics, but a permanent possession."-Jictish Reticu'.

3. Quintessence of Soclatism.

Dr. SCHÄFFLE.

"Precisely the manual needed. Brief, lucid, fair and wi e."-liritish lliekly.

4. Darwinism and Polltics.

D. G. Rrtule, M.A. (Oron.).

New Edition, with two additional Essays on IH MAX WOLTION.

"One of the most suggestrue books we have met with."-f,leibly Horlt.

5. Rellgion of Socialism.

E. BELFORT BAX.

6. Bthics of Sociallsm.

E. BHFERT BAX. Revieut.

7 The Drink Question.

"Plenty" of interesting matler for reflection."-G rith lif

8. Promotion of General Happlness. Frof. M. MACMHA. "A reasoned account of the most advancest and most enlighten cl urslitarian doctrine in a clear and $r$ adable form."-Scotsmu

9. England's ideal, \&c.

EIWARD CARPINTIR.

"The literary ower is unmintakable, their frechness of style, their humour, and their enthusiarm." - l', ll Hall Gate.

10. Soclalism in England.

SIDSEY WH,BH, L.I.B.

"The bcst genctal siew of the subiect from the modern Sncialint side."- Athenum.

11. Prince Bismarch and state Sociallsns.

IV. H. D.W SoN.

"A succinct, wcll-dipested revew of (ierman social and economic legislation : ince $1870 . "-$ Saturlay Rer'tia.

12. Out of trint.

18. The Story of the French Revolution. E. HELFOR RAX. "A irustworthy outline."--Sitsmin.

14. The Co-Operative Commonwealth.

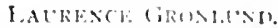

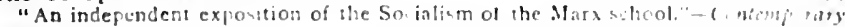
Reticit'.

15. Essays and Addresses.

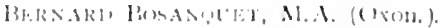

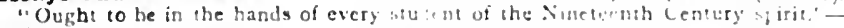
Echo.

"No one can complain of not being able so whdessund what Mr. Bubanquet

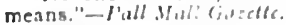

16. Charlty Organisation.

C. S. Lach, Secretaty on Charty Organiation

"A perlect littie manual."-- Athenswm.

ricicty.

"Deserves a "ude uncilation"- Suesman.

17. Thorean's Anti-Slayory and Reform Papers.

"An interese ing collecting of equay"

18. Self-Hclp a Hundred Vears Afo.

Eilied by 11 S. S.M.T.

(i. I. Hor.yolkt.

"Wil be tudied with much henefit b" ail who aic intereved in the amelioration of the condition of the poor." - Murning f'ast.

19. Out of prist.

20. Common sense about Women.

1. 11. Mratilison.

"An armirable ollection of papers, deneating: in the most liberal of int the emancipatio of women."-W"oman's Merabl.

21. The Unearned Incremont.

"A concise but comprehensive volume."-lis ho

W' H. HASON, 


\section{SOCIAL SCIENCE SERIES-(Continued).}

22. Our Destiny.

LAURENCE Gronlund.

"A very vigorous little book, dealing with the influence of Socialism on morals and religion."-Daily Chronicle.

23. Out of print.

24. Out of print.

25. The Land and the Labourers. Rev. C. W. STuBbS, M.A. "This admirable book should be circulated in every village in the country."Manchester Guardian.

26. The Eyolution of Property.

PAUL LAFARgue. "Will prove interesting and profitable to all students of economic history."Scotsman.

27. Crime and its Causes.

W. DOUglas MORRISON. "Can hardly fail to suggest to all readers several new and pregnant reflections on the subject."-A nti-Jacobin.

28. Principles of State Interference.

D. G. Ritchie, M.A.

"An interesting contribution to the controversy on the functions of the State."Glasgow Horald.

29. Out of print.

30. Out of print.

31. Origin of Property in Land. Fustel DE Coulanges. Edited, with an Introductory Chapter on the English Manor, by Prof. W. J. Ashley, M.A.

"His views are clearly stated, and are worth reading."-Saturday Revicw.

32. Out of print.

33. The Co-Operatiye Movement.

Beatrice Potter.

"Without doubt the ablest and most philosophical analysis of the Co-Operative Movement which has yet been produced."-Speaker.

34. Out of print.

35. Modern Humanists.

J. M. RoBERTSON.

"Mr. Robertson's style is excellent-nay, even brilliant-and his purely literary criticisms bear the mark of much acumen."-Times.

36. Outlooks from the New Standpoint.

E. BELFORT BAX.

"Mr. Bax is a very acute and accomplished student of history and economics." -Daily Chronicle.

37. Distributing Co-Operative societies. Dr. Luigi Pizzamiglio. Edited by

F. J. SNELL.

"Dr. Pizzamiglio has gathered together and grouped a wide array of facts and statistics, and they speak for themselves."-Speaker.

38. Collectlyism and Socialism. By A. NACQUet. Edited by W. HeAford. "An admirable criticism by a well-known French politician of the New Socialism of Marx and Lassalle."-Daily Chronicle.

39. The London Programme.

"Brimful of excellent ideas."-A nti-Jacobin.

SidNey WeBB, LL.B.

40. Out of print.

41. The Condition of Labour.

HENRY GEORGE.

"Written with striking ability, and sure to attract attention."-Newcastle Chronicle.

42. The Reyolutionary Spirit preceding the French Reyolution.

Felix Rocquain. With a Preface by Professor Huxley.

"The student of the French Revolution will find in it an excellent introduction to the study of that catastrophe."-Scotsman.

43. The Student's Marx.

EDWARD Aveling, D.Sc.

"One of the most practically useful of any in the Series."-Glasgore Herald.

44. Out of print.

45. Poyerty : Its Genesis and Exodus.

"He states the problems with great force and ciearness." Godard.

46. The Trade Policy of imperial Federation.

"An interesting contribution to the discussion." - Publishers' Circtular. 
47. The Dawn of Radicallsm.

J. BOWLES DALY, LL.D. "Forms an admiable picture of an epoch more pregnant, perhaps, with political instruction than any other in the world's history."-Dally Telegraph.

48. The Destitute Alien in Great Britain. ARxold White; MoNisgur. Crackanthorpe, Q.C.; IV. A. M'Akthuk, M.P.; W. H. WILKINS, \&c.

"Much valuable informati n concernirg a burning question of the day."-Times.

49. Illegltimacy and the inliuence of Seasons on Conduct.

AlBERT LEFFINGWELL, M.D.

"We have not often seen a work based on statistics which is more continuously interesting." - Hestminster liericu.

50. Commerclal Crises of the Nincteenth Century.

H. M. HyNDMAN.

"One of the best and most permanentiy" useful volumes of the Series."-Literary Opinion.

51. The State and Pensions in Old Age. J. A SPENDER and ARThur ACland, M.P. "A careful and cautious examination of the question."-Times.

52. The Fallacy of Saylug. JOHN M. ROBERTSON. "A plea for the reorganisation of our social and industrial system."-Sfeaker.

53. The Irish Peasant. ANON. "A real contribution to the Irish Problem by a close, patient and dispassionate investigator."-Duily Chronicle.

54. The Effects of Machinery on Wages.

Prof. J. S. Nicholson, D.Sc. "Ably rcasooed, clearly stated, impartially written."-Literary Werld.

55. The Social Horizon.

ANon. "A really admirable little book, bright, clear, and unconveotional."-Daily Chronicle.

56. Boclallsm, Utoplan and Scientlfic.
"The body of the book is still fresh and striking."-Daily Chronicle.

57. Land Nationalisation.

FREDERICK ENGELS. "The most instructive and convincing of the popular works on the subject."National Retormer.

58. The Ethic of Usury and Interest.

"The work is marked by genuine ability." -North Brilish Agriculturalist.

59. The Emancipation of Women. "By far the most comprehensive, luminous, and penetrating work on this question that I have yet met with." - Extract from Mr. Gladstone's Preface.

60. The Elght Hours' Question.

JOHN M. ROBERTSON. "A very cogent and sustained argument on what is at present the onpopular side."-Times.

B1. Drunkenness.

GEORGE R. WILSON, M.B. "Well written, carefully reasoned, free from cant, and full of sound sense."National Oliscrier.

32 The Now Reformation.

RAMSDEN BALMFORTH.

"A atriking presentation of the nascent religion, bow best to realize the fersonal and social ideal."-Westminster Retiew.

63. The Agricultural Labourer.

T. E. KEHBEL. "A short summary of his position, with appendices on wages, education, allotmenta, ctc., etc."

64. Ferdinand Lasalle as soclal Rcformer.

E. BerNSTEIN. "A wortby addition to the Social Science Series" -Notk British Economist.

65. England's Foreign Trade In XIXth Cencury. "Full of valuable information, carefully compiled." -Times.

68. Theory and Pollicy of Labour Protection. Dr. Schifflet.

A. L. BOWLEY.

67. History of Rochdalo Ploneers.

"Brought down from $1 \mathrm{H}_{14}$ to the Rochdale Congress of $1892 . "-$ Co.Op. Ne: ${ }^{\circ}$.

68. Rights of Women.

M. Ostrariorskt. "An admirable storehouse of precedents, convenienely arranied"-Dail Chron

69. Dwellinga of the People. 1.OKKL: WORTILINGION. "A valuable contribution to one of the most pressing problems of the dav."Daily Chronicle.

70. Out of front.

71. Out of print.

72 Land systemn of Rustralasia.

IV'M. lipps.

"Exceedingly valuable at the present time of depreasion and difficulty."Scots. Mug. 


\section{SOCIA SOIENCE SERIES-(Continued).}

73. Out of print.

74. Population and the Sooial System.

Dr. NiTH.

75. Out of print.

76. British Freewomen.

C. C. Stopes.

77. Out of print.

78. Out of print.

79. Three Montlas in a Workshop.

80. Darwlnism and Race Progress.

81. Local Taxatlon and Finance.

82. Perils to British Trade.

83. The Soclal Contract.

81. Labour upon the Land.

85. Moral Pathology.

86. Parasitism, Organic and Soclal.

87. Allotments and Small Holdings.

88. Money and its Relations to Prloes.

89. Sober by Act of Parliament.

yo. W orkers on thelr Industries.

91. Reyolution and Counter-Reyolution.

92. Oyer-Production and Crises.

93. Local Government and State Ald.

94. Yillage Communities in India.

95. Anglo-American Trade.

96. A Plain Examlnation of Soclalism.

P. GOHRE, with Pref. by Prof. Ely. Prof. J. B. Haycraft. G. H. BLUNDEN. E. Burgis. J. J. Rousseau. Edited by H. J. Tozer. Edited by J. A. Hobson, M.A. Artuur E. Giles, M.D., B.Sc. MASSART and VANDERVELDE. J. L. GREEN. L. L. PRICE. F. A. Mackenzie. F. W. Galton. KARL MARX.

K. RODBERTUS.

S. J. Chapman. B. H. BADEN-Powell, M.A., C.I.E.

S. J. ChAPMAN.

97. Commerclal Federation \& Colonia

98. Selections from Fourier.

99. Public-House Reform.

100. The Yillage Problem.

101. Toward the Light.

102. Christian Socialism in England.

703. The Philosophers and the French Revolution.

104. The History of the English Corn Laws.

105. The Biology of British Politics.

106. Rates and Taxes as Affecting Agriculture.

107. A Practlcal Programme for Working Men.

108. John Thelwall.

109. Rent, Wages and Profits in Agriculture. Gustave Sinionson, M.A., M.D. C. GIDE and J. FRANKLIN. A. N. Cumming. G. F. Millin. L. H. BERENS. A. V. WOODWORTH. Prof. P. A. WADIA. Prof. J. S. NiCHOLSON, M.A. Charles H. HARVEy. Prof. J. S. Nicholson, M.A. ANON. Chas. Cestre, Litt.D. Prof. J. S. Nicholson.

\section{DOUBLE VOLUPES, 3s. 6d.}

1. Life of Robert Owen.

LLOYD JONES.

2. The Impossibility of Social Democracy: a Second Part of "The Quintessence of Socialism ".

3. Condition of the Working Class in England in 1844

4. The Principles of Social Economy.

5. Social Peace.

6. A Handbook of Soclallsm.

7. Sociallsm : its Growth and Outcome.

8. Economic Foundations of Society.

Dr. A. SCHÄFFLE.

FrEDERICK ENGELS.

YVES GuYoT.

G. von Schultze-GAEvERNitz.

W. D. P. BLiss.

W. MORRIS and E. B. BAX.

A. LORIA.

\section{SWAN SONNENSCHEIN \& CO. LIM., LONDON}

NEW YORK : CHIALLES SCRIBNER'S SONS. 
THR ABERDERN ONIVERSITY PRESS LIMITED. 
THE LIBRARY

UNIVERSITY OF CALIFORNIA

Santa Barbara

THIS BOOK IS DUE ON THE LAST DATE STAMPED BELOW.

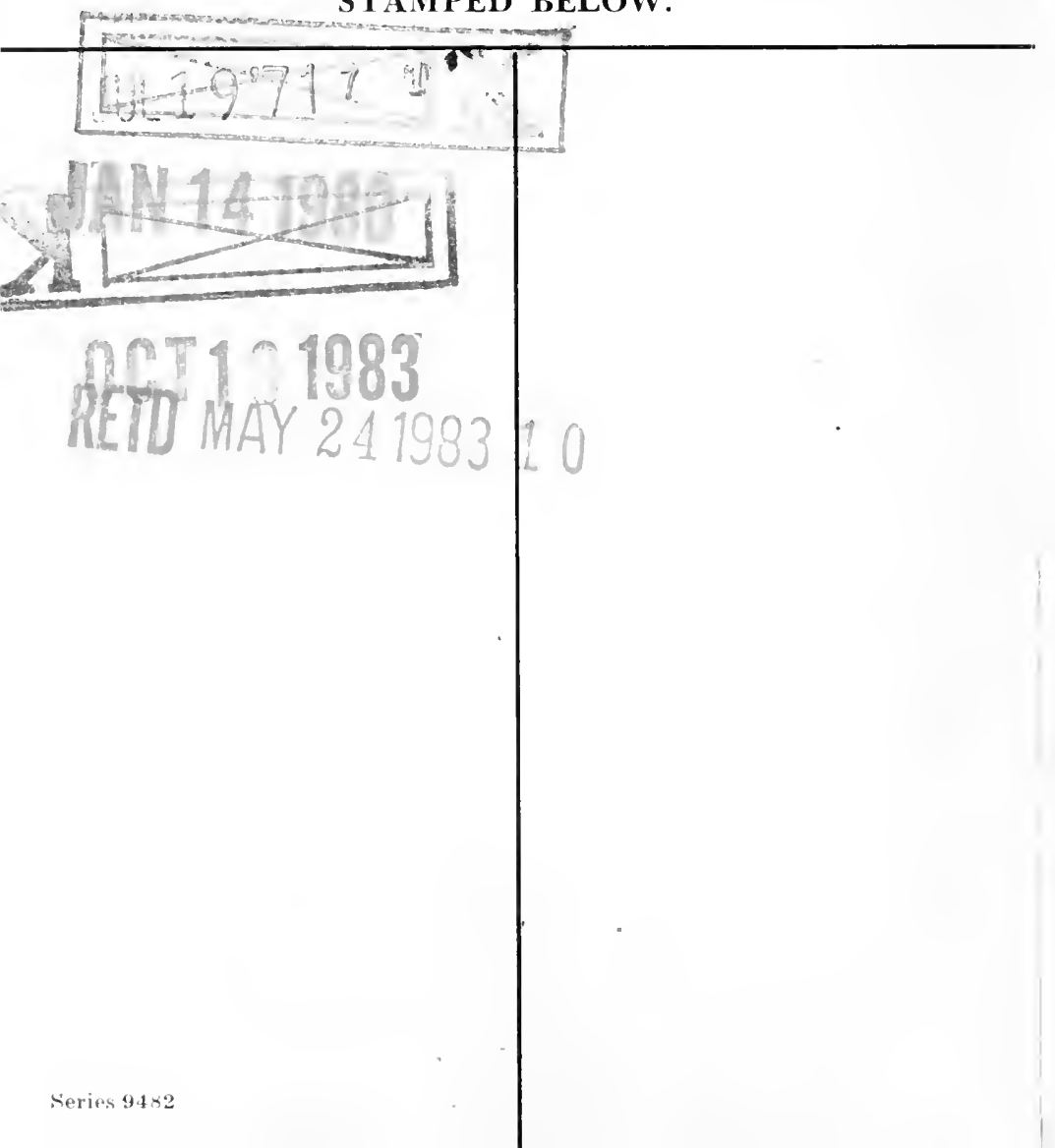



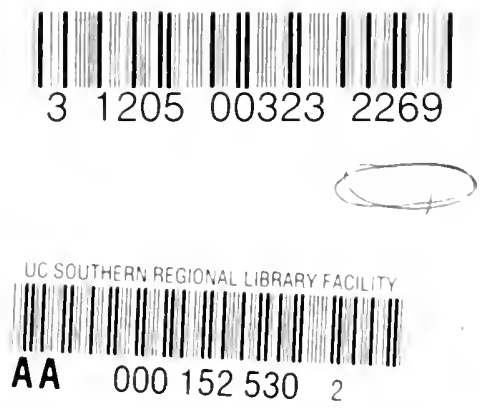
